\title{
Estimated Use of Water in Nevada, 1985
}

By E. James Crompton and Elizabeth A. Frick

U.S. GEOLOGICAL SURVEY

Open-File Report 96-106

Prepared in cooperation with the

NEVADA DEPARTMENT OF CONSERVATION AND NATURAL RESOURCES DIVISION OF WATER RESOURCES

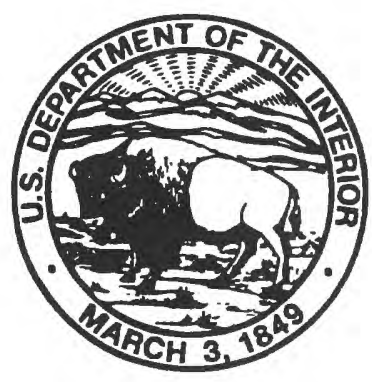

Carson City, Nevada 1996 


\title{
U.S. DEPARTMENT OF THE INTERIOR BRUCE BABBITT, Secretary
}

\author{
U.S. GEOLOGICAL SURVEY \\ GORDON P. EATON, Director
}

Any use of trade names in this publication is for descriptive purposes

only and does not constitute endorsement by the U.S. Government

For additional information write to:

District Chief

U.S. Geological Survey

333 West Nye Lane, Room 203

Carson City, NV 89706-0866
Copies of this report can be purchased from:

U.S. Geological Survey

Branch of Information Services

Box 25286

Denver, CO 80225-0286 


\section{CONTENTS}

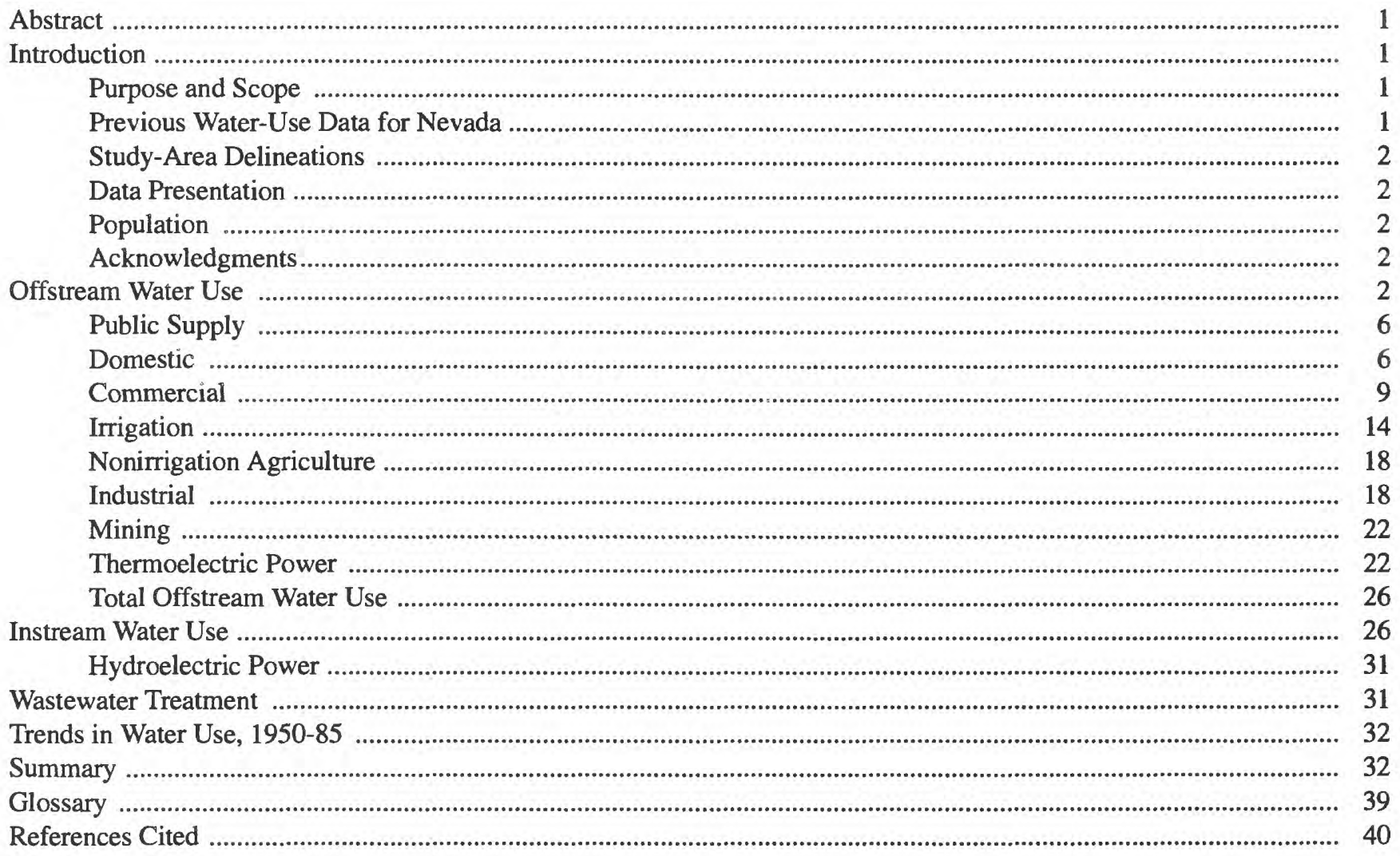

\section{FIGURES}

1-3. Maps showing:

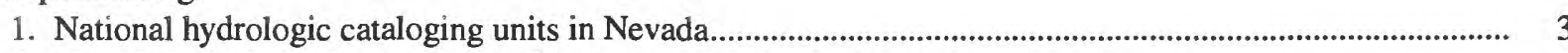

2. Nevada counties and other selected features ............................................................................................

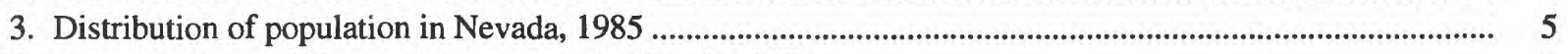

4. Diagrams showing public-supply water use in Nevada, 1985 ........................................................................ 7

5. Maps showing water withdrawals for public supply, by hydrologic cataloging unit, 1985................................. 8

6. Diagrams showing domestic water use, 1985 ...................................................................................................... 10

7. Maps showing water withdrawals for self-supplied domestic use, by hydrologic cataloging

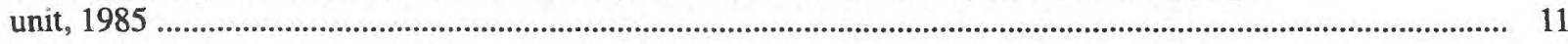

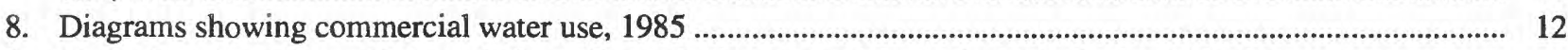

9. Maps showing water withdrawals for self-supplied commercial use, by hydrologic cataloging

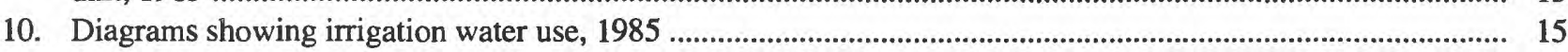

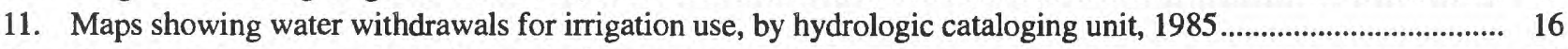

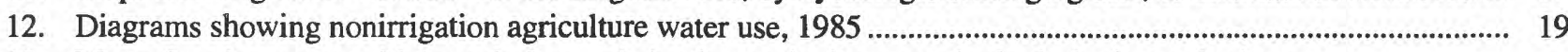

13. Maps showing water withdrawals for nonirrigation agriculture use, by hydrologic cataloging

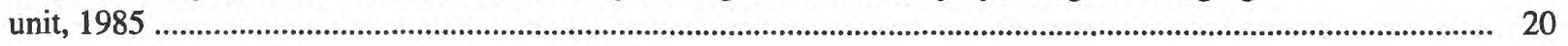

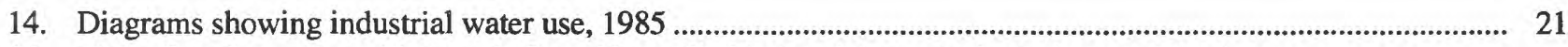

15. Maps showing water withdrawals for self-supplied industrial use, by hydrologic cataloging

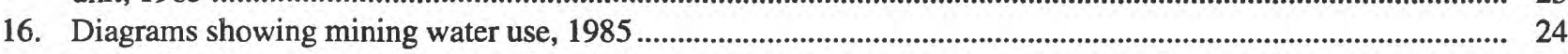

17. Maps showing water withdrawals for mining use, by hydrologic cataloging unit, 1985 ................................... 25 
18. Diagrams showing thermoelectric power water use, 1985

19. Maps showing self-supplied water withdrawals for thermoelectric power use, by hydrologic cataloging unit, 1985

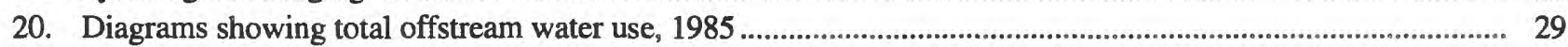

21. Maps showing total offstream water withdrawals, by hydrologic cataloging unit, 1985 ................................. 30

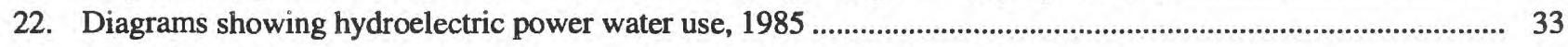

23-24. Maps showing:

23. Hydroelectric power water use, by hydrologic cataloging unit, 1985

24. Water releases from public wastewater treatment facilities, by hydrologic cataloging unit, 1985 .

25-26. Graphs showing:

25. Trends in offstream water withdrawals and population, 1950-85.

26. Trends in water withdrawal for public supply and irrigation use, 1950-85.

\section{TABLES}

1. National hydrologic cataloging units and corresponding Nevada hydrographic areas, grouped by Nevada regions and basins

2-3. Area, population, and population density, 1985, by:

2. Hydrologic cataloging unit .

3. County

4-5. Public-supply freshwater use, 1985 , by:

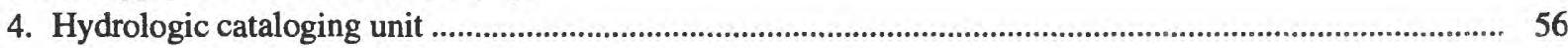

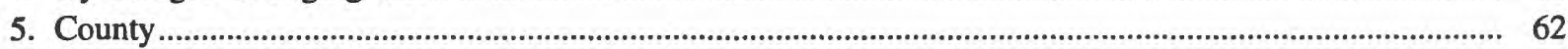

6-7. Estimated public-supply water withdrawals, 1985 , by:

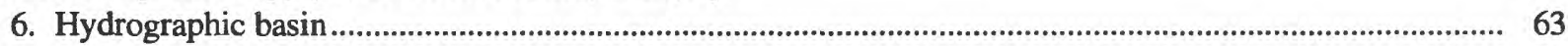

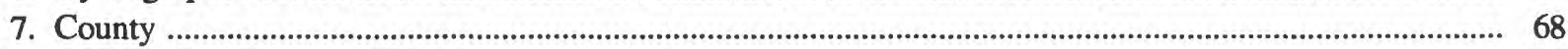

8-9. Domestic freshwater use, 1985 , by:

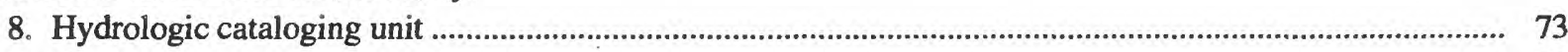

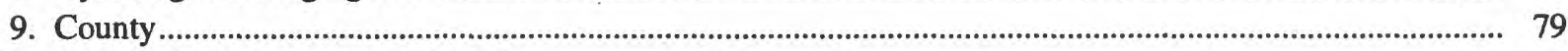

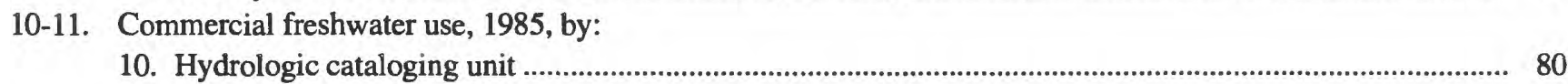

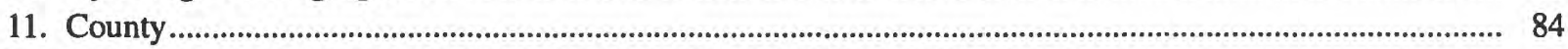

12-13. Irrigation water use, 1985 , by:

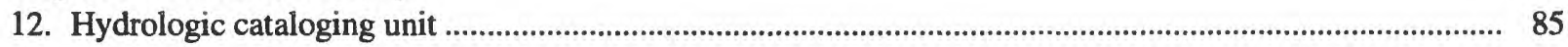

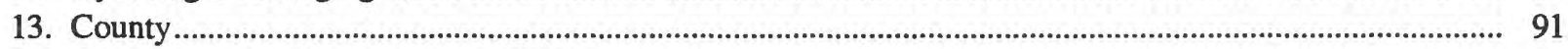

14-15. Nonirrigation agriculture water use, 1985 , by:

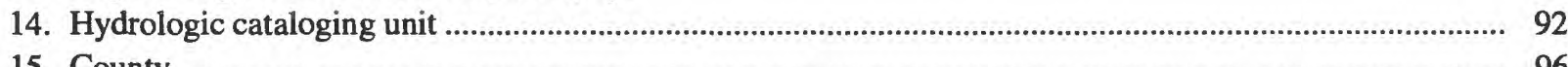

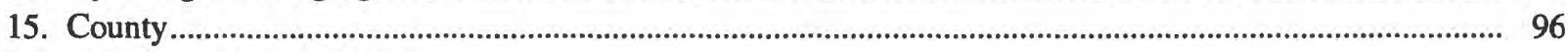

16-17. Industrial water use, 1985 , by:

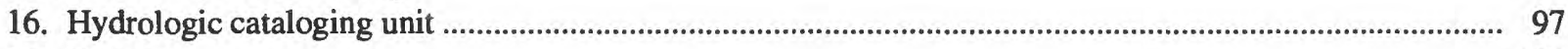

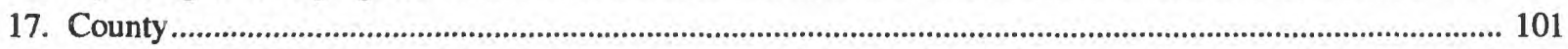

18-19. Mining water use, 1985 , by:

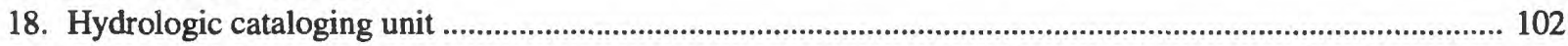

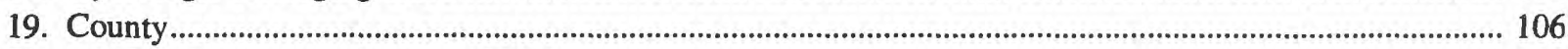

20-21. Thermoelectric power water use, 1985, by:

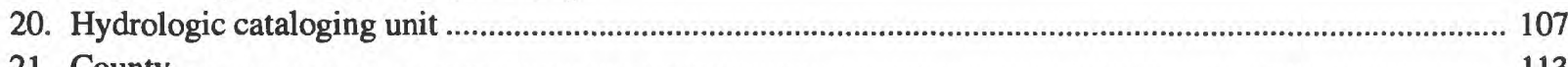

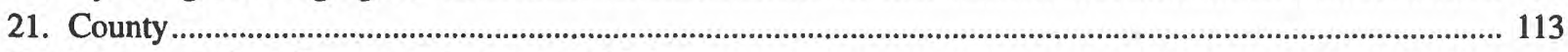

22-23. Total water use for offstream categories, 1985, by:

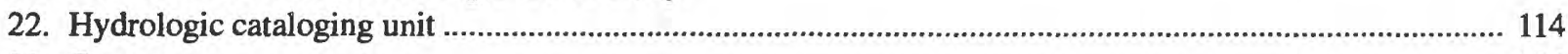

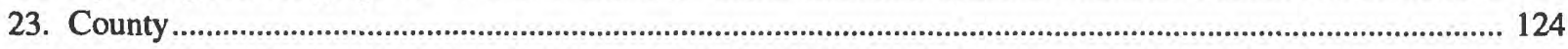


24-25. Summary of water withdrawals for offstream water-use categories, 1985 , by:

24. Hydrologic cataloging unit

25. County

26-27. Surface-water withdrawals for offstream water-use categories, 1985 , by:

26. Hydrologic cataloging unit

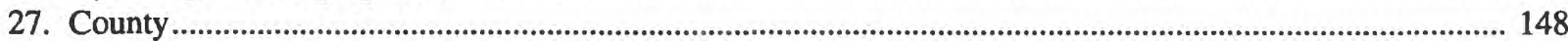

28-29. Ground-water withdrawals for offstream water-use categories, 1985, by:

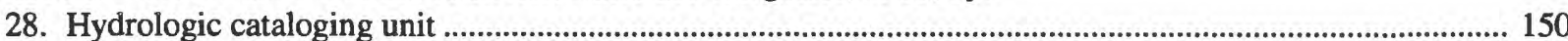

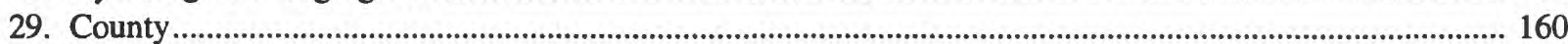

30-31. Hydroelectric-power water use, 1985, by:

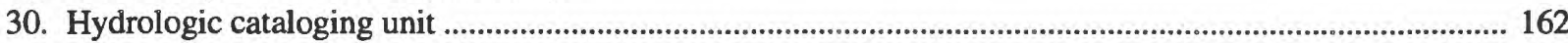

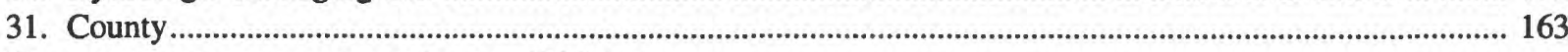

32-33. Wastewater-treatment water releases, 1985, by:

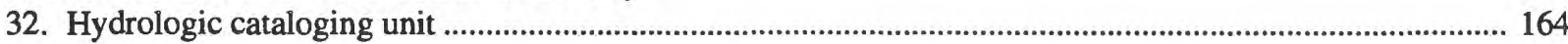

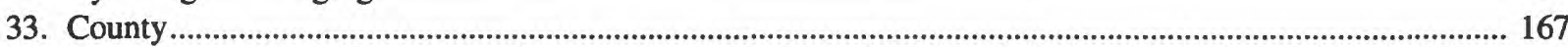

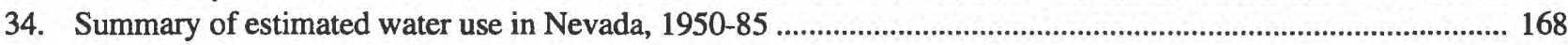

\section{CONVERSION FACTORS AND WATER-QUALITY UNIT}

\begin{tabular}{|c|c|c|}
\hline Multiply & By & To obtain \\
\hline acre & 0.4047 & hectare \\
\hline acre-foot (acre-ft) & 1,233 & cubic meter \\
\hline acre-foot per acre (acre-ft/acre) & 1,233 & cubic meter per acre \\
\hline acre-foot per year (acre-ft/yr) & 1,233 & cubic meter per year \\
\hline gallon (gal) & 0.003785 & cubic meter \\
\hline gallon per day (gal/d) & 0.003785 & cubic meter per day \\
\hline gallon per capita per day (gal/capita/d) & 0.003785 & cubic meter per capita per day \\
\hline gigawatthour (GWh) & 1,000 & megawatthour \\
\hline gigawatthour (GWh) & $1,000,000$ & kilowatthour \\
\hline mile (mi) & 1.609 & kilometer \\
\hline million gallons per day (Mgal/d) & 3,785 & cubic meter per day \\
\hline million gallons per day (Mgal/d) & 1.121 & thousand acre-feet per year \\
\hline square mile $\left(\mathrm{mi}^{2}\right)$ & 2.590 & square kilometer \\
\hline thousand acre-feet per year (thousand acre-ft/yr) & 1,233 & thousand cubic meters per year \\
\hline thousand acre-feet per year (thousand acre-ft/yr) & 0.893 & million gallons per day \\
\hline
\end{tabular}

Water-Quality Unit: Milligram per liter (mg/L). 


\title{
Estimated Use of Water in Nevada, 1985
}

\author{
By E. James Crompton and Elizabeth A. Frick
}

\section{Abstract}

Water withdrawals in Nevada during 1985 were estimated to average 3,700 million gallons per day (Mgal/d) of fresh and saline water for offstream uses. In this report, offstream water use is classified as public supply, domestic, commercial, irrigation, nonirrigation agriculture, industrial, mining, and thermoelectricpower generation. Public-supply withdrawals were estimated to be $290 \mathrm{Mgal} / \mathrm{d}$, and self-supplied withdrawals were estimated to be $12 \mathrm{Mgal} / \mathrm{d}$, domestic; $7.4 \mathrm{Mgal} / \mathrm{d}$, commercial; $3,300 \mathrm{Mgal} / \mathrm{d}$, irrigation; $26 \mathrm{Mgal} / \mathrm{d}$, nonirrigation agriculture; $10 \mathrm{Mgal} / \mathrm{d}$, industrial; $30 \mathrm{Mgal} / \mathrm{d}$, mining; and $24 \mathrm{Mgal} / \mathrm{d}$, thermoelectric power.

During 1985, estimated surface-water withdrawals were $2,800 \mathrm{Mgal} / \mathrm{d}$ and estimated groundwater withdrawals were $920 \mathrm{Mgal} / \mathrm{d}$. Saline-water withdrawals were $8.4 \mathrm{Mgal} / \mathrm{d}$, all from ground water. Reclaimed wastewater averaged about $11 \mathrm{Mgal} / \mathrm{d}$.

Freshwater consumptive use was estimated to be $1,900 \mathrm{Mgal} / \mathrm{d}$ during 1985 . Consumptive use by irrigation, $1,700 \mathrm{Mgal} / \mathrm{d}$, accounted for about 90 percent of all consumptive use.

Water used for hydroelectric power generation, the only instream use compiled in this report, was estimated to be $8,900 \mathrm{Mgal} / \mathrm{d}$.

Public wastewater-treatment facilities returned $130 \mathrm{Mgal} / \mathrm{d}$.

Since 1950, irrigation has been the largest offstream water use. Public use, which has paralleled Nevada's rapid population growth, increased 620 percent from 1950 to 1985 .

\section{INTRODUCTION}

Estimates of water use in the Nation have been made every 5 years. This report presents estimates for 10 categories of water use in Nevada during 1985:
Public supply, domestic, commercial, irrigation, nonirrigation agriculture, industrial, mining, thermoelectric power generation, hydroelectric-power generation, and wastewater treatment. The first eight categories are considered offstream uses of water. Water used for hydroelectric power generation is considered an instream use of water. Wastewater treatment is considered a miscellaneous use of water.

\section{Purpose and Scope}

The purpose of this report is to summarize the 1985 water-use information collected through a cooperative program between the Nevada Division of Water Resources and the U.S. Geological Survey. This cooperative effort is part of the National Water-Use Information Program-an ongoing Federal-State cooperative program designed to collect, store, and distribute water-use information at local, State, and national levels.

Information on the trends in water use in Nevada from 1950 to 1985 is shown in figures 25 and 26.

\section{Previous Water-Use Data for Nevada}

Earlier reports on Statewide water use in Nevada were published by Harrill and Worts (1968) and Smales and Harrill (1971). Water-use estimates aggregated by State for 1985 were published by Solley and others (1988). Earlier water-use estimates aggregated by State are: MacKichan (1951, 1957), MacKichan and Kammerer (1961), Murray (1968), Murray and Reeves (1972, 1977), and Solley and others (1983). Summaries of water use in 1985 by individual States are presented in the 1987 National Water Summary (Carr and others, 1990). 


\section{Study-Area Delineations}

At the national level, the U.S. Geological Survey, in cooperation with the U.S. Water Resources Council, defined boundaries and codes delineating basins of the United States. State "Hydrologic Unit Maps" for the Nation depict a system divided into hydrologic regions, subregions, accounting units, and cataloging units (Seaber and others, 1984). This system divides Nevada into 4 hydrologic regions, 12 subregions, 16 accounting units, and 72 hydrologic cataloging units (Seaber and others, 1984). These hydrologic cataloging units are shown in figure 1 and referenced in table 1 by map number, corresponding hydrologic cataloging unit number, and name.

At the State level, the U.S. Geological Survey, in cooperation with the Nevada Division of Water Resources, delineated boundaries for hydrographic regions and areas in Nevada (Rush, 1968), which are used by local and State agencies for water-resource planning and management. These 256 hydrographic areas are composed of the major valleys in the State and have been grouped into 14 regions and basins.

A list of the hydrologic cataloging units and the Nevada hydrographic areas, grouped by the State's hydrographic regions, is provided in table 1. Some delineations of the hydrologic cataloging units and the Nevada hydrographic areas differ. For the purposes of this study, where a hydrographic area did not coincide with the hydrologic cataloging unit, the small overlap was divided into water-use and non-water-use contributing parts (table 1).

\section{Data Presentation}

For each category, the following information is presented: (1) type of water use included in the estimates, (2) amount and source of water used, (3) distribution of withdrawals, (4) changes in estimates from 1975 to 1985 , and (5) data sources and methods used to make estimates. Pie diagrams show the source of the water withdrawn and its use. Maps are included to show the level of use by hydrologic cataloging unit. Tables present various water-use categories by hydrologic cataloging unit and by county. County boundaries and names and other features of Nevada are shown in figure 2. The hydrologic cataloging units are grouped and subtotaled by the State's hydrographic regions to allow comparison of the 1985 estimates with estimates in previous State reports. Although discussions in this report generally use million gallons per day as a reporting unit, data are also reported in the tables in thousand acre-feet per year.

Water-use data are average daily quantities derived from annual totals. These numbers were rounded to two significant figures for values greater than 1 and to one significant figure for values less than 1. All numbers were rounded independently; therefore, the sum of individually rounded values may not equal the totals.

\section{Population}

In 1985, Nevada's population was estimated to be 967,760 people (Bureau of Business and Economic Research, University of Nevada, Reno, written commun., 1986). More than 80 percent of the State's residents live in Clark and Washoe Counties (fig. 3). This uneven distribution of the population has led to what are known within the State as urban and rural counties. For this report, counties with a population density of fewer than 15 people per square mile are considered rural. The rural counties are Churchill, Elko, Esmeralda, Eureka, Humboldt, Lander, Lincoln, Lyon, Mineral, Nye, Pershing, Storey, and White Pine. For comparisons between population and water use, the area acreage, estimated 1985 population, and population density of each hydrologic cataloging unit (map number) are listed in table 2; the same information by county is listed in table 3.

\section{Acknowledgments}

The authors thank staff of the Nevada Division of Water Resources (NDWR) and the other State and Federal agencies that provided information for this report. In addition, special thanks is given to city and county officials and representatives of water systems and industries in Nevada; without their cooperation much of the data in this report could not have been obtained.

\section{OFFSTREAM WATER USE}

Offstream water use includes water diverted or withdrawn from a surface- or ground-water source and conveyed to the place of use. Self-supply withdrawal, 


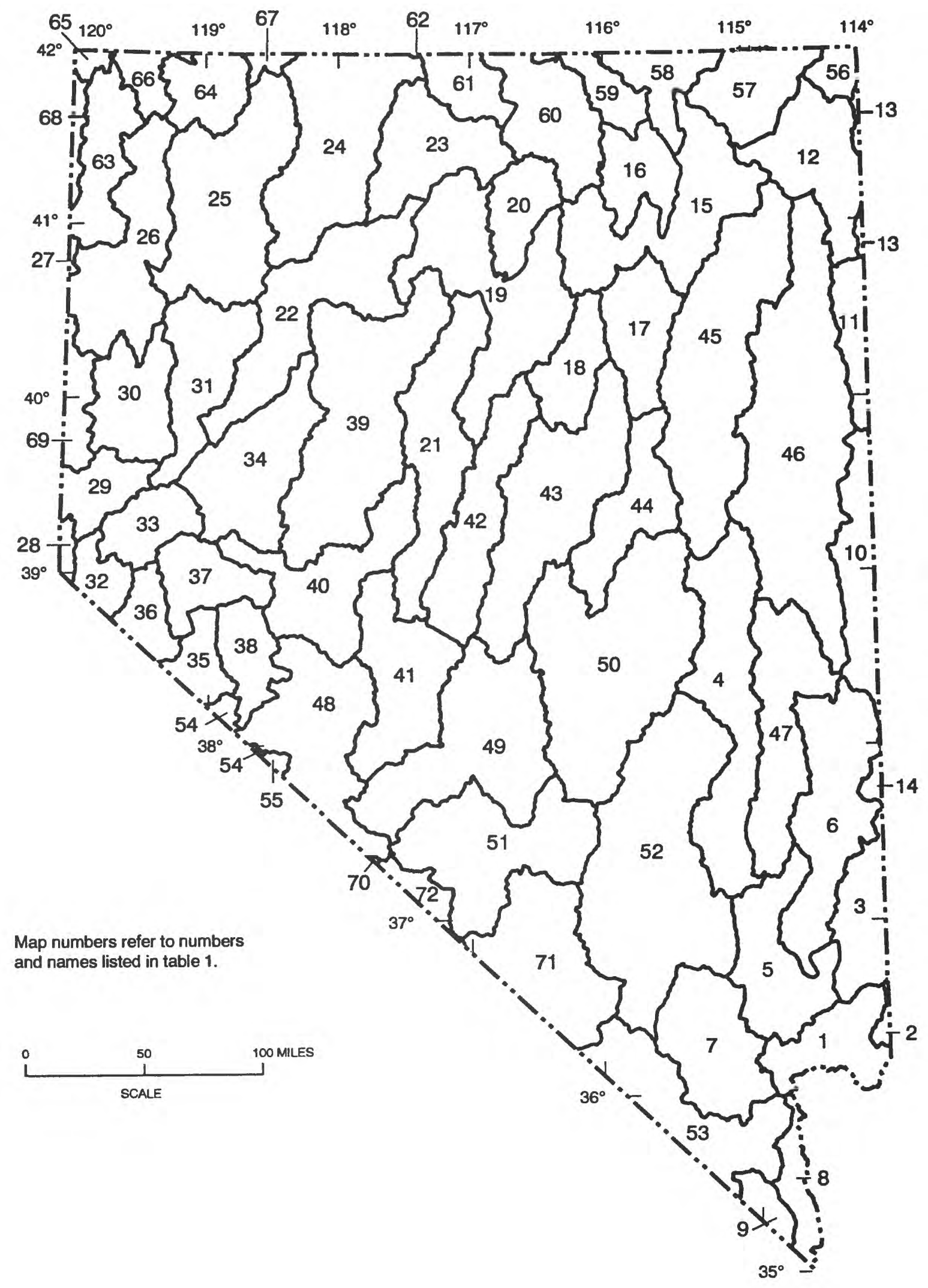

Figure 1. National hydrologic cataloging units in Nevada. (Source: U.S. Geological Survey, 1974.) 


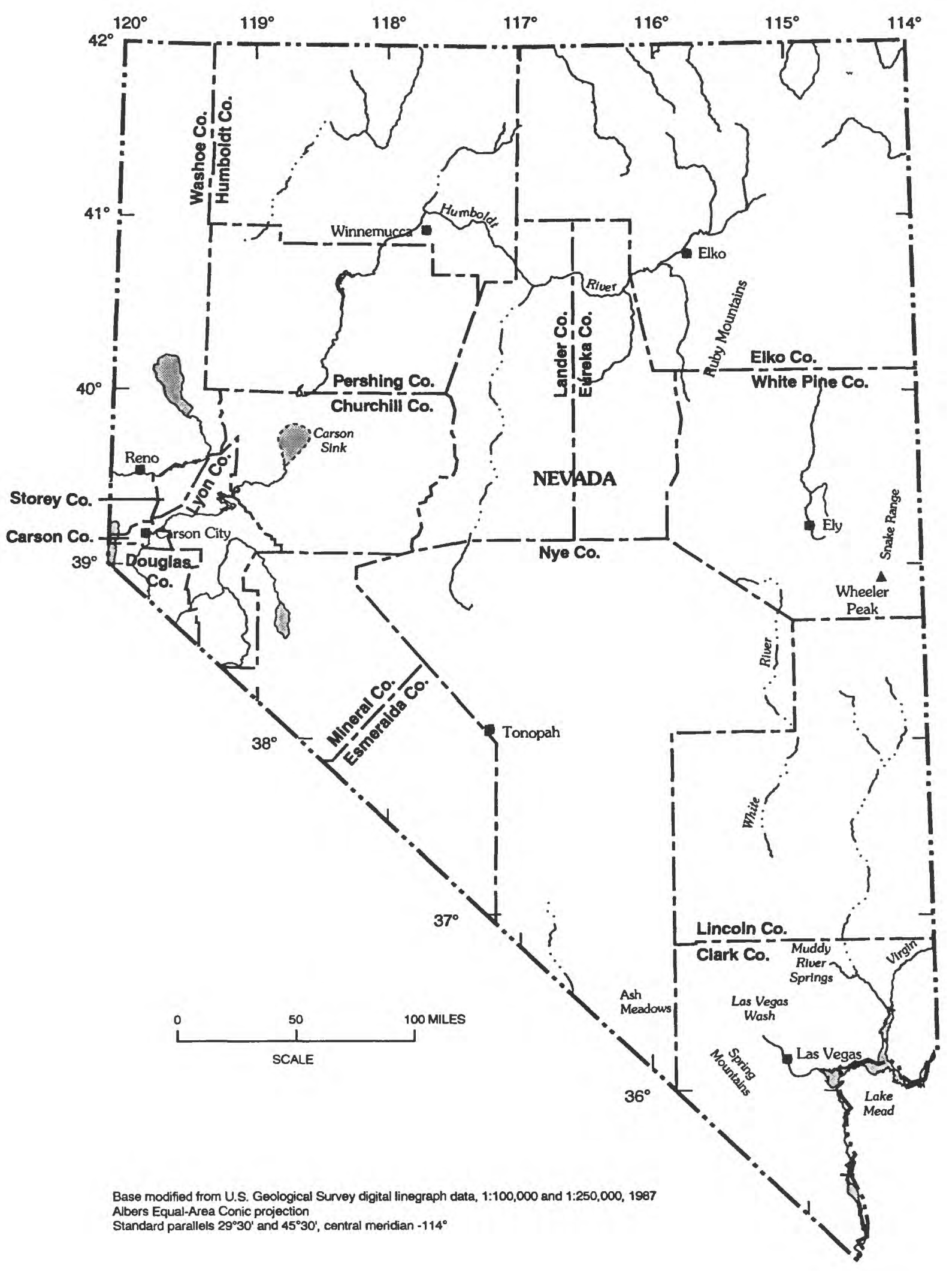

Figure 2. Nevada counties and other selected features. 


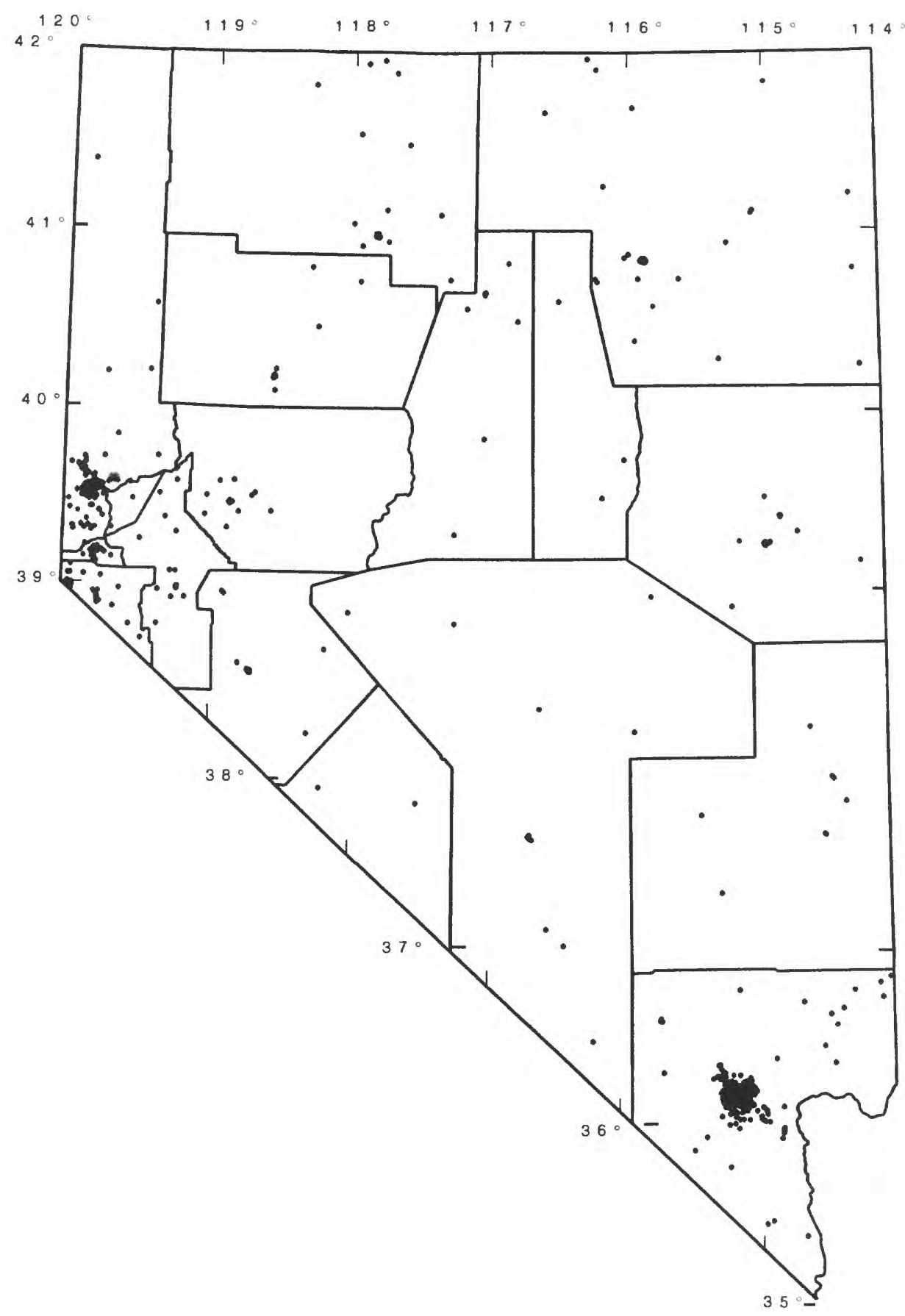

Figure 3. Distribution of population in Nevada, 1985. Each dot represents a census tract with at least 100 people. Compiled by U.S. Geological Survey from U.S. Bureau of the Census data. 
public-supply delivery (where applicable), and consumptive-use estimates are listed in this report for eight categories of use-public supply, domestic, commercial, irrigation, nonirrigation agriculture, industrial, mining, and thermoelectric power.

\section{Public Supply}

Public supply, as used in this report, refers to water withdrawn by public and private water suppliers and delivered to domestic, commercial, industrial, and thermoelectric power users. Each of these water suppliers provides water to at least 25 people or 15 connections.

Public-supply facilities in Nevada withdrew approximately $290 \mathrm{Mgal} / \mathrm{d}$ in 1985 , which is less than 8 percent of all offstream water withdrawals in the State. Of the public-supplied withdrawals, $190 \mathrm{Mgal} / \mathrm{d}$ (67 percent) was surface water and $94 \mathrm{Mgal} / \mathrm{d}$ (33 percent) was ground water (fig. 4A). Public-supply facilities delivered approximately 66 percent $(190 \mathrm{Mgal} / \mathrm{d})$ of their water to domestic users, 19 percent $(54 \mathrm{Mgal} / \mathrm{d})$ to commercial users, and 3 percent $(8.8 \mathrm{Mgal} / \mathrm{d})$ to industrial and thermoelectric users (fig. 4B). The remaining 12 percent ( $36 \mathrm{Mgal} / \mathrm{d}$ ) was estimated as public use and loss, which represents water primarily used for firefighting and street washing, and conveyance losses.

In many rural areas of the State no public watersupply systems exist or withdrawals are less than $0.1 \mathrm{Mgal} / \mathrm{d}$ (fig. 5A). Of the more than 300 publicsupply facilities in Nevada, only 39 facilities use surface water for all or part of their supply. Figures $5 \mathrm{~B}$ and $5 \mathrm{C}$ show that most communities in the State depend on ground water as a source of public-supply water, yet the largest withdrawals are surface water.

The two major sources of surface water for public supply are Lake Mead (fig. 2) for the Las Vegas area. and the Truckee River and its tributaries for the Reno area (see 1 and 29 in table 3); thus, Clark and Washoe Counties are the largest users of public-supply water (table 5). Public-supply facilities in the Las Vegas area (map numbers 1 and 7) delivered $185 \mathrm{Mgal} / \mathrm{d}$, or 64 percent of the total public-supplied water in the State.

The negative numbers for public use and loss in table 4 represent public water supply delivered from another hydrologic cataloging unit. This interbasin transfer of water occurs where Colorado River water withdrawn from the Black Mountains Area (map number 1) is delivered to Las Vegas Valley (map number 7), Eldorado Valley (map number 53), and Colorado River Valley (map number 8); a water company in the Truckee Meadows (map number 29) sells water to two water-supply companies in Lemmon Valley (map number 69); and spring and well water in Goshute Valley (map number 46) is piped to West Wendover, Nev., and Wendover, Utah (map number 11).

From 1975 to 1985 , public-supply withdrawails increased 69 percent. This increase in withdrawals reflects the increase in the population served, from 545,000 (Murray and Reeves, 1977, p. 20) to 882,000 (Solley and others, 1988, p. 13), during this same 10 -year period. Surface-water withdrawals are increasing faster than ground-water withdrawals, primarily due to increased use of Colorado River water in the Las Vegas area.

Public-supply data were obtained by questionnaires sent to many water-supply companies in the State. The U.S. Environmental Protection Agency (written commun., 1986) and the Nevada Department of Environmental Protection (written commun., 1986) provided lists of water-supply companies (community and non-community). Water-supply-company data from the Nevada Division of Water Resources (written commun., 1986), Washoe County Public Utilities (oral commun., 1986), U.S. Bureau of the Census (1983), and Resource Concepts, Inc. (1984) also were used. Few companies in Nevada measure both withdrawals and deliveries, so conveyance losses were estimated to be 10 percent of withdrawals unless additional information was available. Public-supply data by supplier or town is listed in table 6 by hydrographic basin and in table 7 by county.

\section{Domestic}

Domestic water use includes water for household purposes, such as drinking, food preparation, bathing, washing clothes and dishes, flushing toilets, and watering lawns and gardens. Water for domestic use is furnished to Nevada's 967,760 people by both publicsupplied and self-supplied systems. Combined publicsupplied deliveries and self-supplied withdrawals for domestic use was $200 \mathrm{Mgal} / \mathrm{d}$ in 1985. Public-supplied water is the primary means for furnishing water to the State's residents. In 1985, more than 90 percent of domestic water was supplied by public-supply companies (fig. 6A). Approximately 50 percent of water used 


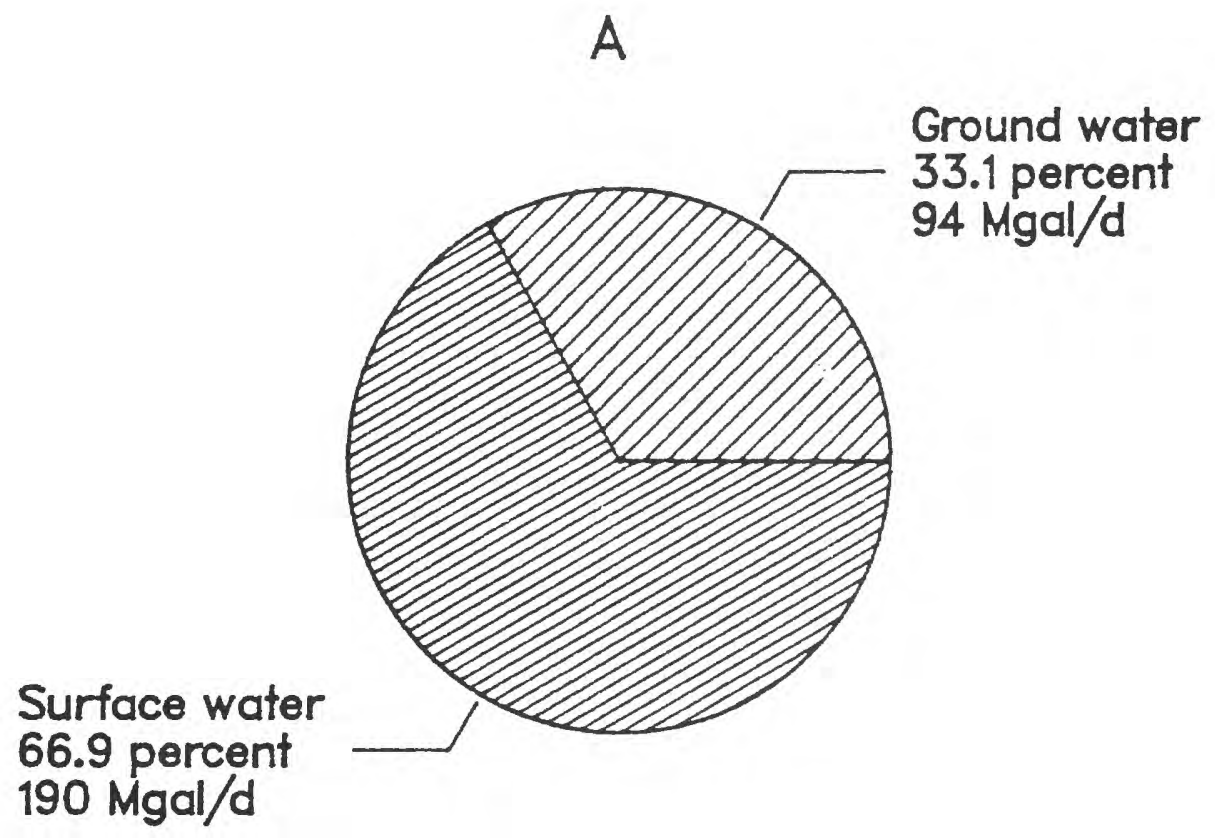

B

Domestic

65.8 percent $190 \mathrm{Mgal} / \mathrm{d}$

Public use and losses

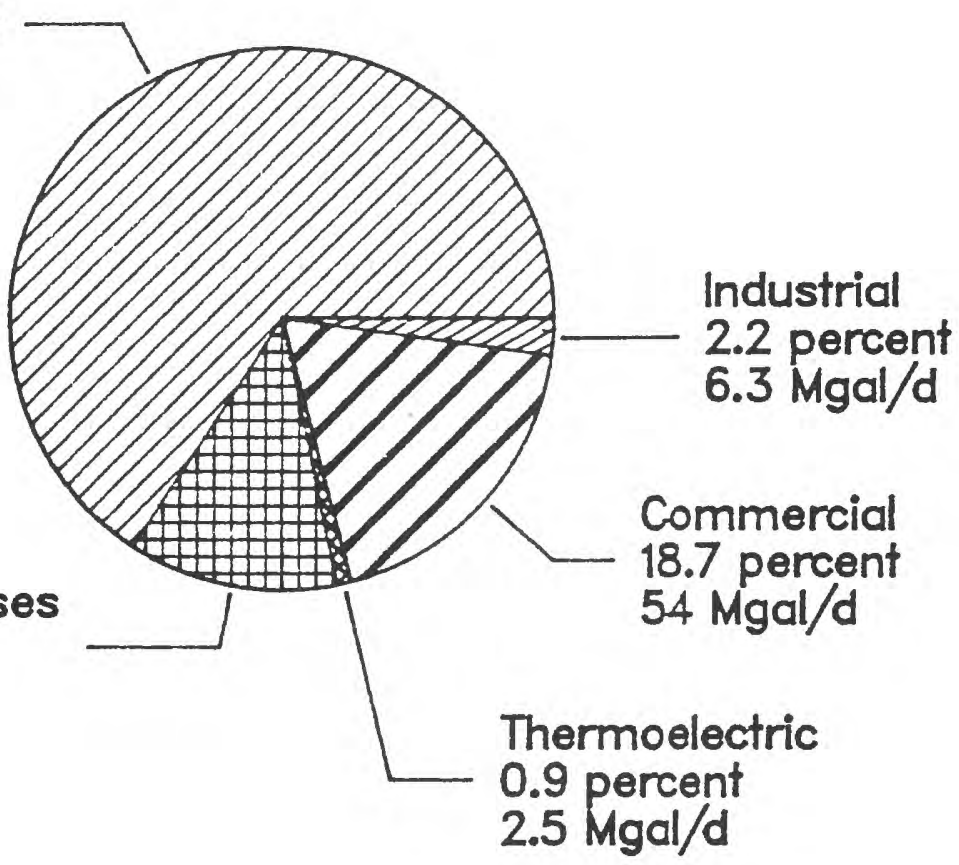

Figure 4. Public-supply water use in Nevada, 1985. A. Withdrawals by source. B. Deliveries by category. Abbreviation: Mgal/d, million gallons per day. 
A

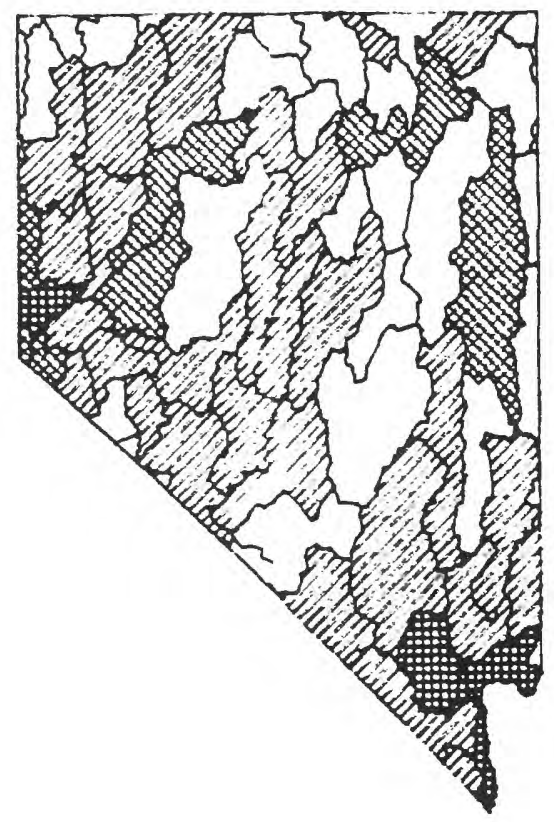

c

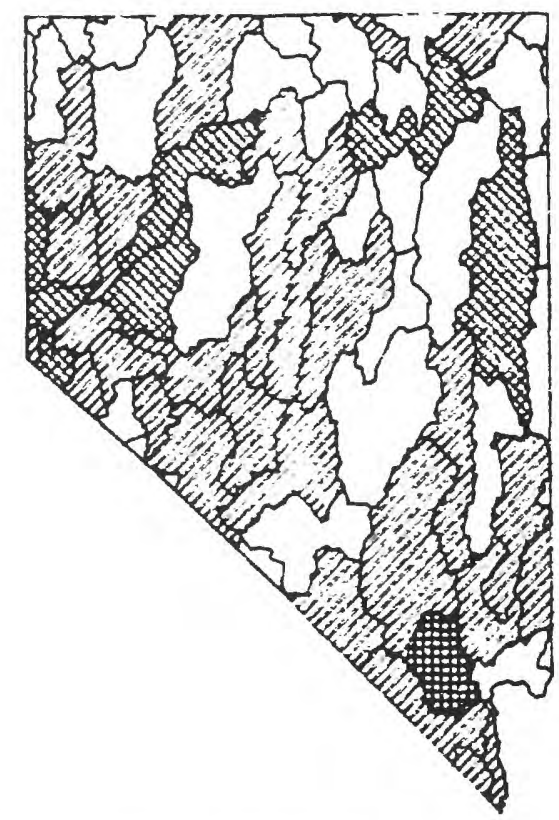

B

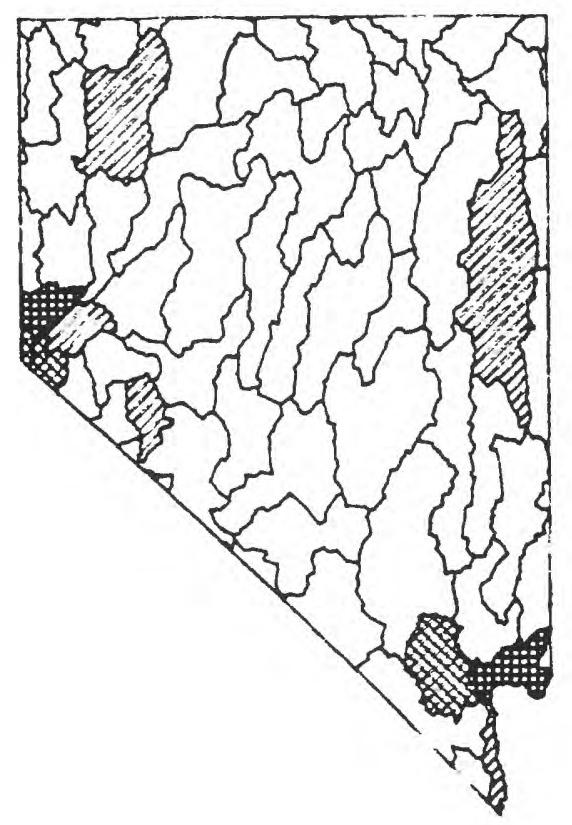

\section{EXPLANATION}

Range, in million

gailons per doy

$[-\ldots]<0.1$

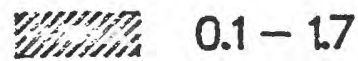

18-36

$37-180$

Figure 5. Water withdrawals for public supply, by hydrologic cataloging unit, 1985. A. Total withdrawals. B. Surfacewater withdrawals. C. Ground-water withdrawals. 
for domestic purposes is consumed (fig. 6B). The percentage of consumptive use is highest for single-family homes with lawns.

Self-supplied withdrawals (individual wells or diversions) were about 95 percent from ground water $(12 \mathrm{Mgal} / \mathrm{d})$ and 5 percent from surface water $(0.6$ $\mathrm{Mgal} / \mathrm{d})$. The greatest self-supplied domestic withdrawals were in the Las Vegas Valley (map number 7), although that represents only 2 percent of the domestic water use in the valley (fig. 7A). Statewide, ground water is the most common source of self-supplied domestic water, as seen in figure $7 \mathrm{~B}$ and $7 \mathrm{C}$.

Withdrawals for domestic use are presented by hydrologic cataloging unit in table 8 and by county in table 9. Public-supply systems delivered $190 \mathrm{Mgal} / \mathrm{d}$ to domestic users. Las Vegas Valley (map number 7) had the most public-supplied deliveries for domestic use, $110 \mathrm{Mgal} / \mathrm{d}$.

The population listed in tables 8 and 9 are fulltime residents of that community. For most areas of Nevada, this number underestimates the population by not including tourists and other part-time residents who use water. Therefore, the per capita use shown in the table is larger than the actual per capita use for the given population. The largest per capita use was in the Laughlin area (map number 8), where the percentage of permanent residents is relatively small in comparison to the number of casino employees who live in Arizona but work in Laughlin and the number of tourists who visit the area.

Since 1975, withdrawals for self-supplied domestic use increased from $8.4 \mathrm{Mgal} / \mathrm{d}$ (Murray and Reeves, 1977 , p. 22) to $12 \mathrm{Mgal} / \mathrm{d}$ in 1985.

Information on public-supplied domestic use and the population served was obtained from questionnaires sent to the water-supply companies and from the 1980 U.S. Bureau of the Census figures for percentage of population served by public water-supply companies (U.S. Bureau of the Census, 1983, p. 30-7). Data on self-supplied domestic use were calculated by subtracting the total population from the population served by water-supply companies and applying a per capita use rate estimated for each region, which averaged $140 \mathrm{gal} / \mathrm{d}$ per person. It was assumed that most selfsupplied domestic water is from ground water.

\section{Commercial}

Commercial water use includes water for casinos, motels, restaurants, office buildings, other commercial facilities, and civilian and military institutions. In 1985 , more than $61 \mathrm{Mgal} / \mathrm{d}$ of water was used for commercial purposes. Public-water suppliers delivered $54 \mathrm{Mgal} / \mathrm{d}$, or about 88 percent (fig. $8 \mathrm{~A}$ ). The remaining 12 percent $(7.4 \mathrm{Mgal} / \mathrm{d})$ was self supplied. Ground water was the principal source for self-supplied water, furnishing over 95 percent $(7 \mathrm{Mgal} / \mathrm{d})$ of the withdrawals. Approximately 20 percent of commercial water use was estimated to be consumed (fig. 8B).

Figures 9A, 9B, and 9C show the distribution of total surface-water and ground-water self-supplied commercial withdrawals, by hydrologic cataloging unit. Las Vegas Valley (map number 7) led the State in commercial water use with $42 \mathrm{Mgal} / \mathrm{d}$. Public-supplied deliveries for commercial use in the Las Vegas Valley were more than $37 \mathrm{Mgal} / \mathrm{d}$, and self-supplied withdrawals were $5.4 \mathrm{Mgal} /$; both values are also highs for the State. Table 10 shows commercial water-use data by hydrologic cataloging unit, and table 11 shows the same information by county.

A trend in commercial water use with time cannot be accurately determined because in previous years this use was not separated from either public-supply or industrial-use categories.

Public-supplied commercial water-use estimates for Las Vegas Valley were from water-supply companies and self-supplied commercial estimates were from the Nevada Division of Water Resources sitespecific pumping inventory. Many water-supply companies in Nevada either do not measure the amount of water they deliver, or do not total the amount of water delivered to commercial customers. Of the few companies that total the amount of water delivered to commercial customers, none outside of Las Vegas Valley separates commercial and industrial use into two categories. Unless additional information was available, industrial deliveries were assumed to be zero.

Estimates of public-supplied commercial wateruse outside of Las Vegas Valley were obtained from water-supply companies and by multiplying estimates of the number of employees for similar categories of commercial establishments (U.S. Bureau of the Census, 1985a, p. 17-35; Nevada Commission on Economic Development, 1985) by water-use estimates per employee. 


\section{A}
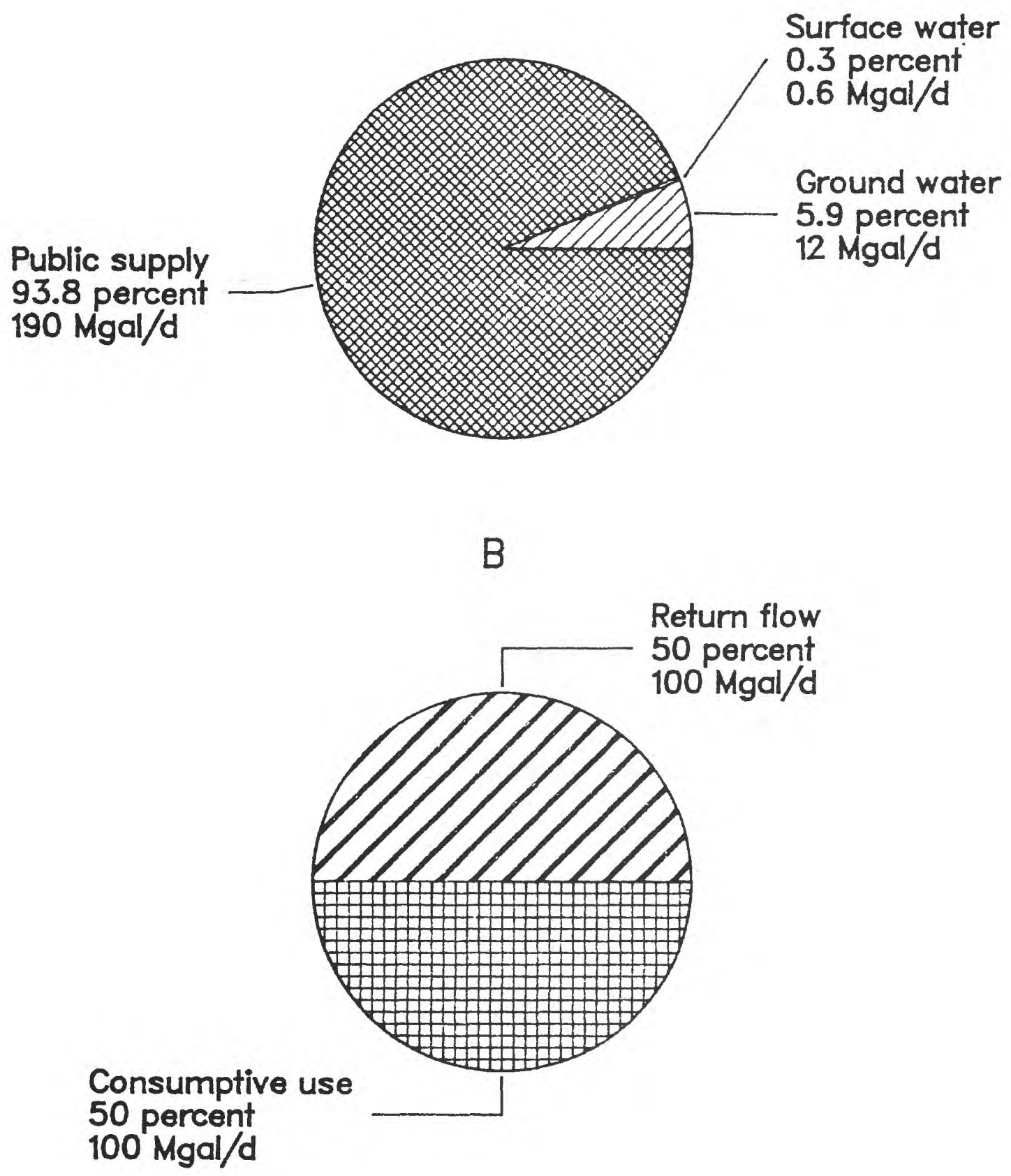

Figure 6. Domestic water use, 1985. A. Withdrawals, by source and deliveries. B. Disposition by type. Abbreviation: Mgal/d, million gallons per day. 
A

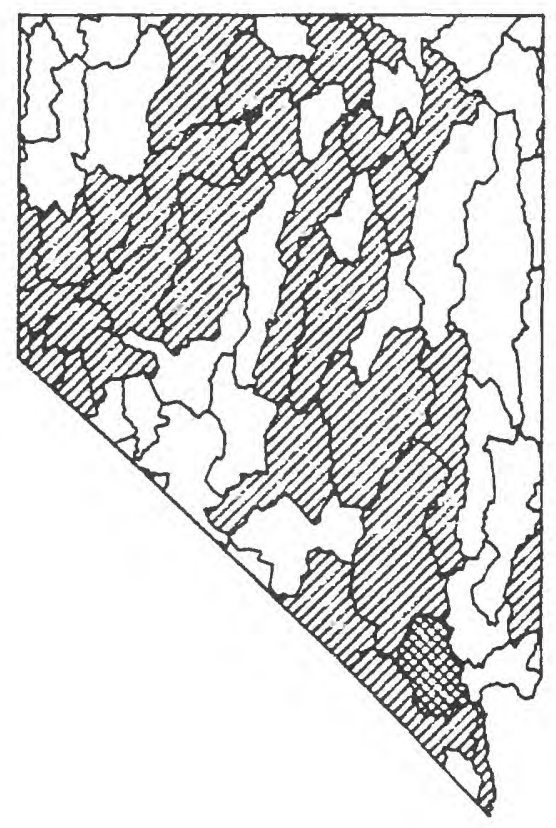

C

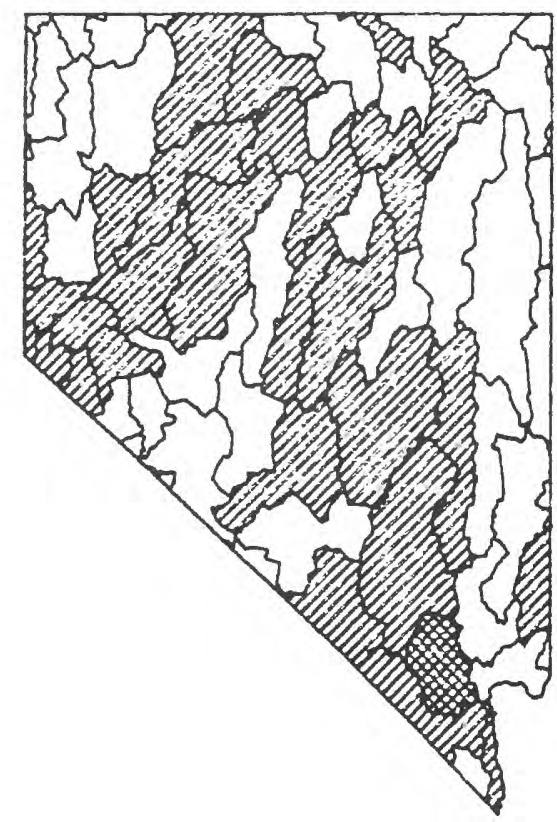

B

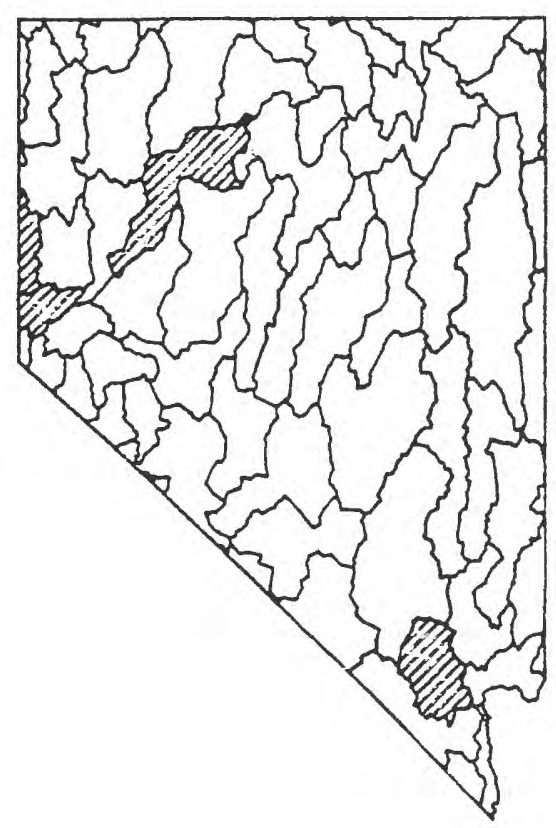

EXPLANATION

Range, in million

gallons per day

$\square<0.1$

$0.1-1.7$

$1.8-36$

Figure 7. Water withdrawals for self-supplied domestic use, by hydrologic cataloging unit, 1985. A. Total withdrawals. B. Surface-water withdrawals. C. Ground-water withdrawals. 


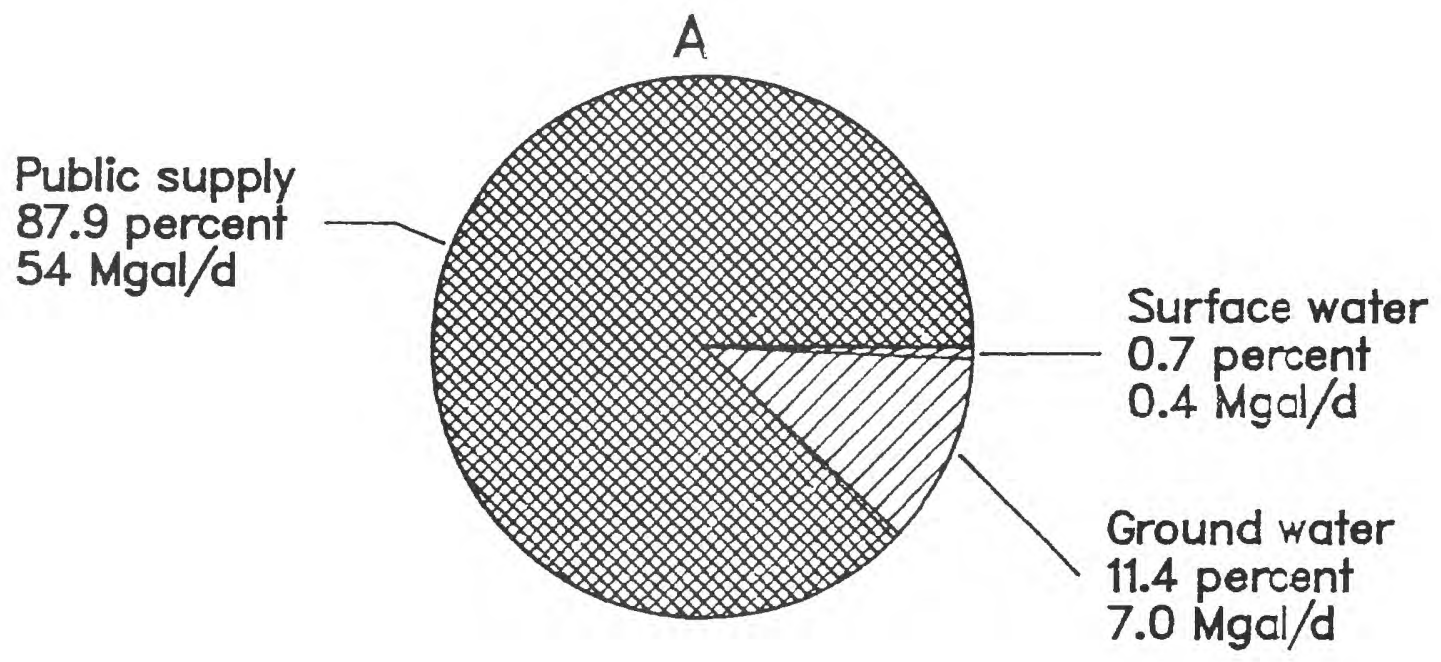

B

Return flow 80.3 percent $49 \mathrm{Mgal} / \mathrm{d}$

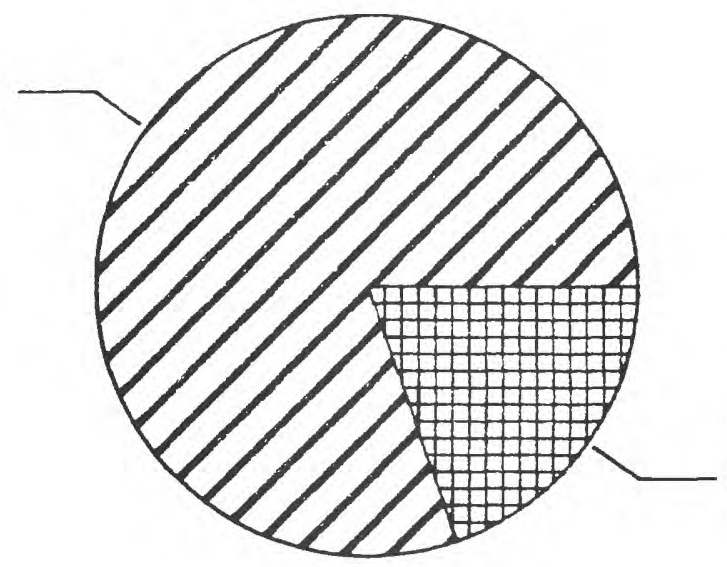

Consumptive use

19.7 percent $12 \mathrm{Mgal} / \mathrm{d}$

Figure 8. Commercial water use, 1985. A. Withdrawals, by source and deliveries. B. Disposition, by type. Abbreviation: Mgal/d, million galions per day. 
A

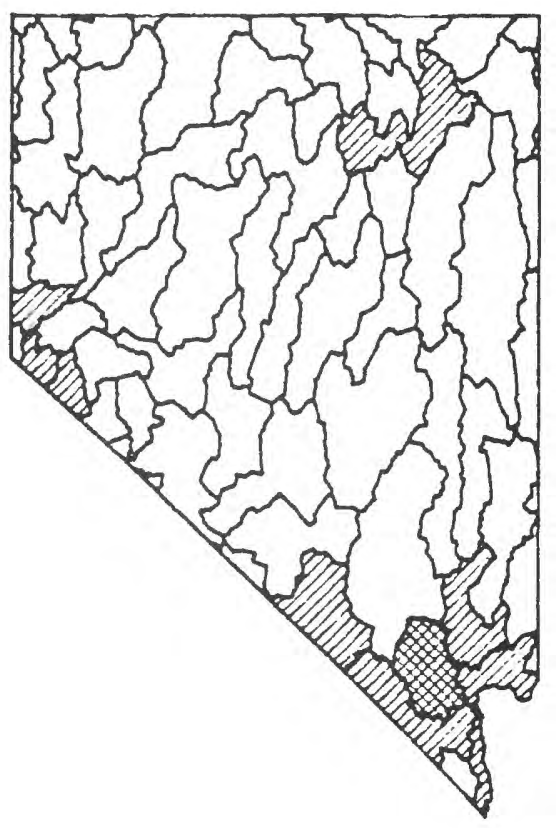

C

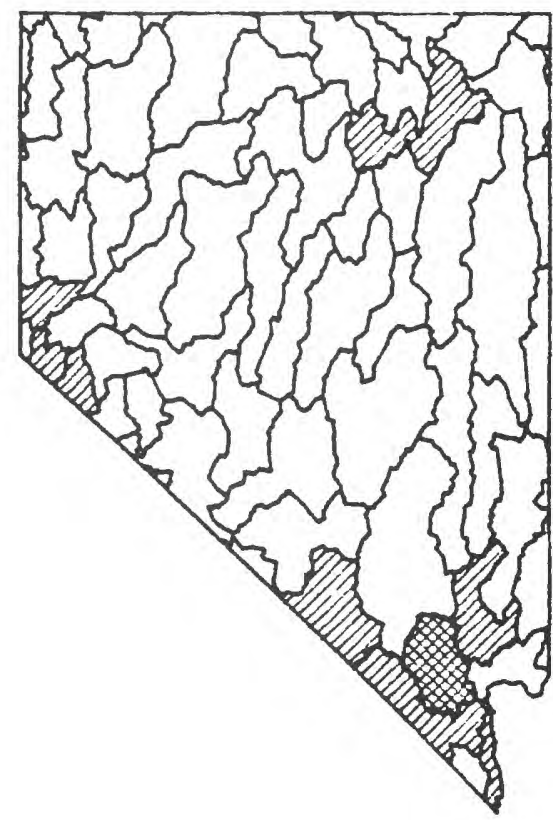

B

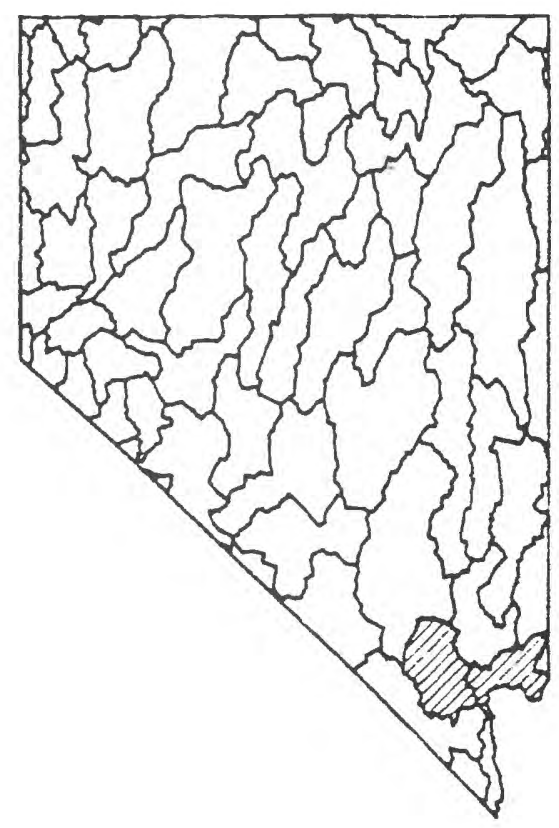

\section{EXPLANATION}

Range, in million

gallons per day

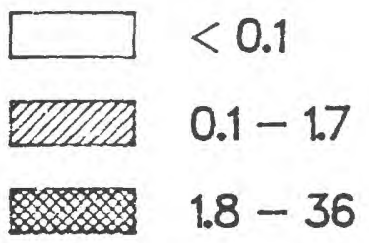

Figure 9. Water withdrawals for self-supplied commercial use, by hydrologic cataloging unit, 1985. A. Total withdrawals. B. Surface-water withdrawals. C. Ground-water withdrawals. 
Self-supplied commercial water-use estimates were derived by multiplying EPA's estimates of the population served for 380 non-community, publicwater systems (Gary Silverman, U.S. Environmental Protection Agency, written commun., 1986) by 20 $\mathrm{gal} / \mathrm{capita} / \mathrm{d}$ for bars, gas stations, retail stores, restaurants, churches, parks, schools, and summer camps; by $65 \mathrm{gal} / \mathrm{capita} / \mathrm{d}$ for ranches and small hotels and casinos; and by $100 \mathrm{gal} / \mathrm{capita} / \mathrm{d}$ for bottling companies, hot-spring resorts, and large hotels and casinos.

\section{Irrigation}

Irrigation water use consists of water applied to lands to grow crops and pastures, as well as water used to irrigate golf courses and parks. Water withdrawn for irrigation is self-supplied or supplied by irrigation companies or districts.

Irrigation accounts for nearly 90 percent of all offstream withdrawals in Nevada. In 1985, about 3,300 $\mathrm{Mgal} / \mathrm{d}$ were withdrawn to irrigate 850,000 acres of crops, pastures, golf courses, and parks. Surface water was the source of 77 percent $(2,600 \mathrm{Mgal} / \mathrm{d})$, ground water 22 percent $(750 \mathrm{Mgal} / \mathrm{d})$, and reclaimed wastewater less than 1 percent ( $11 \mathrm{Mgal} / \mathrm{d}$; fig. 10A). Conveyance losses accounted for more than 21 percent (730 Mgal/d; fig. 10B).

In decreasing order of acreage, field crops grown in Nevada are alfalfa and other hay, barley, winter and spring wheat, potatoes, alfalfa seed, and vegetablesall require irrigation to grow in Nevada's semiarid climate (Nevada Department of Agriculture, 1986; U.S. Bureau of the Census, 1984). In addition to harvested field crops, more than 25 percent of the irrigated acreage in Nevada is pasture (U.S. Bureau of the Census, 1984). The average amount of water withdrawn for irrigation was 4.4 acre-ft per irrigated acre, which includes conveyance losses. Flood irrigation was used on more than 80 percent of the 850,000 acres irrigated in the State in 1985 (tables 12 and 13).

Withdrawals for irrigation are greater in the northern half of the State, where agricultural productivity is greatest due to cooler air temperatures, higher average annual precipitation, and shallower depths to ground water (fig. 11A). The greatest surface-water withdrawals for irrigation are along parts of the Humboldt River in north-central Nevada and the Carson River in west-central Nevada (fig. 11B). Although ground water supplies less than one-fourth the irrigation water used in the State, its use is widely distributed (fig. 11C). Irrigation withdrawal data are shown by hydrologic cataloging units in table 12 , and by county in table 13 . Storey County is the only county where the amount of water used for irrigation is less than the minimum reporting level.

Estimates of irrigated acreage for 1985 are 1 percent smaller than for 1975 , but estimates for total water use for irrigation are 9 percent greater because higher consumptive-use rates were used for the 1985 calculations (U.S. Soil Conservation Service, 1985). The higher rates are based on an increase in ground-water use and more efficient systems. Since 1975, surfacewater withdrawal estimates for irrigation have remained relatively constant; however, variations are not accurately reflected in 5-year estimates because of changes in the availability of surface water. Groundwater withdrawals have increased from $530 \mathrm{Mgal} / \mathrm{d}$ in 1975 (Murray and Reeves, 1977 , p. 24) to $750 \mathrm{Mgal} / \mathrm{d}$ in 1985.

Although treated wastewater accounts for less than half a percent of the water used statewide for irrigation, based on 1985 categories its use has steadily increased from 6.7 Mgal/d in 1975 (Murray and Reeves, 1977, p. 24 and 26) to $11 \mathrm{Mgal} / \mathrm{d}$ in 1985. Treated wastewater is used to irrigate alfalfa, pasture, and golf courses, mostly in Las Vegas Valley (map number 7) and Carson and Eagle Valleys (map number 32). Several golf courses in Las Vegas and Eagle Valleys are irrigated entirely with reclaimed wastewater.

Although irrigation is the largest use of water in Nevada, few site-specific irrigation water-use measurements are available. Estimates of irrigation water use were derived from data collected by several Federal and State agencies. The availability, accuracy, and year of source data differed widely. Because some source data were available only by county and other source data were available only by hydrographic areas, additional estimates were made for more than 350 geographic areas between county and hydrographic-area boundaries. The tables and figures present estimates for these geographic areas aggregated by county and by hydrologic cataloging unit.

Irrigated-acreage estimates were derived from 1983 through 1985 Crop and Water Surveys for 24 hydrographic areas and 1983 through 1985 Pumpage Inventories for 16 hydrographic areas (Nevada Division of Water Resources, written commun., 1986), U.S. Geological Survey estimates for 4 hydrographic areas, and 1985 Truckee-Carson Irrigation District 

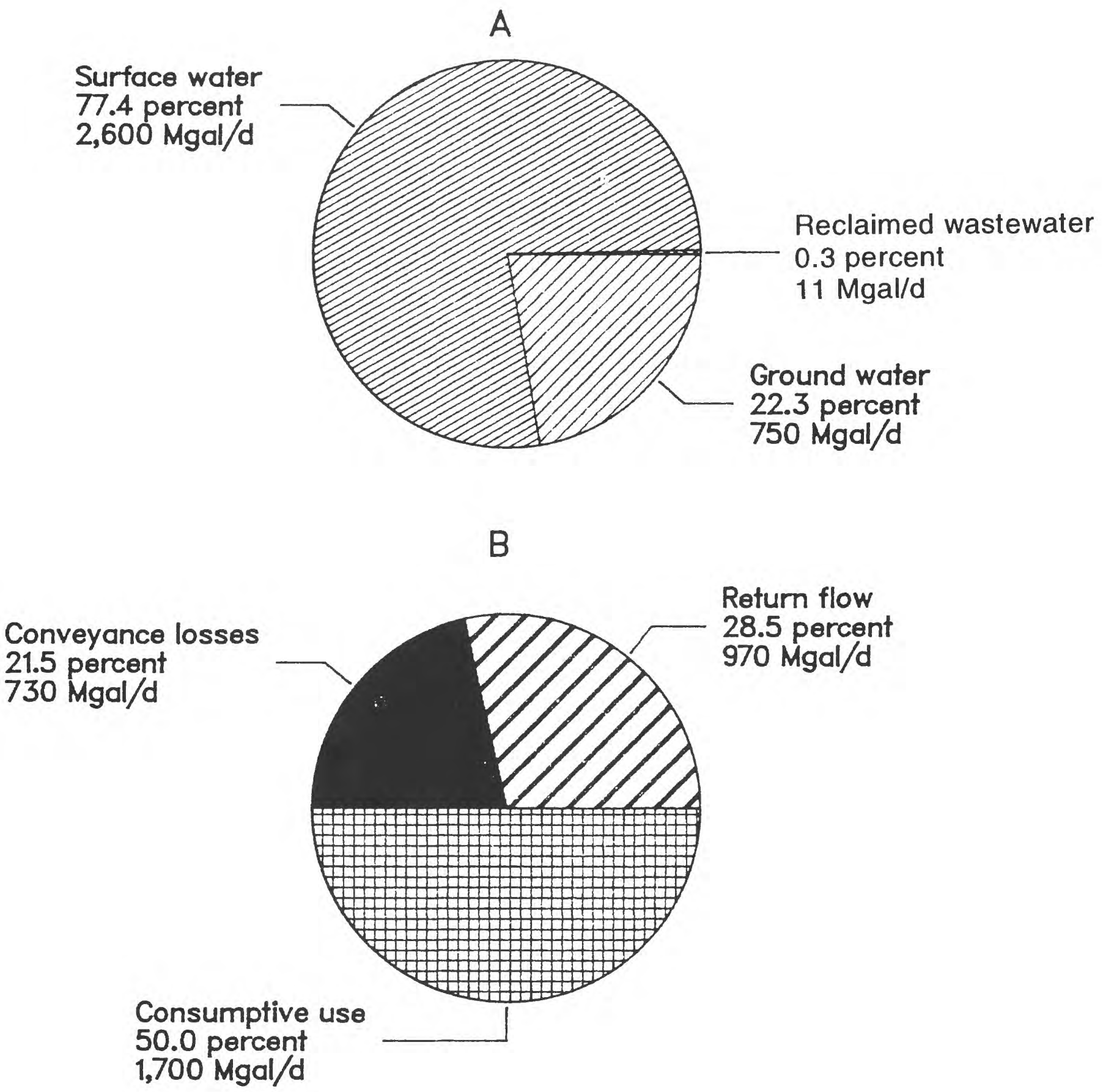

Figure 10. Irrigation water use, 1985. A. Withdrawals by source, and deliveries. B. Disposition by type. Abbreviation: Mgal/d, million gallons per day. 


\section{A}
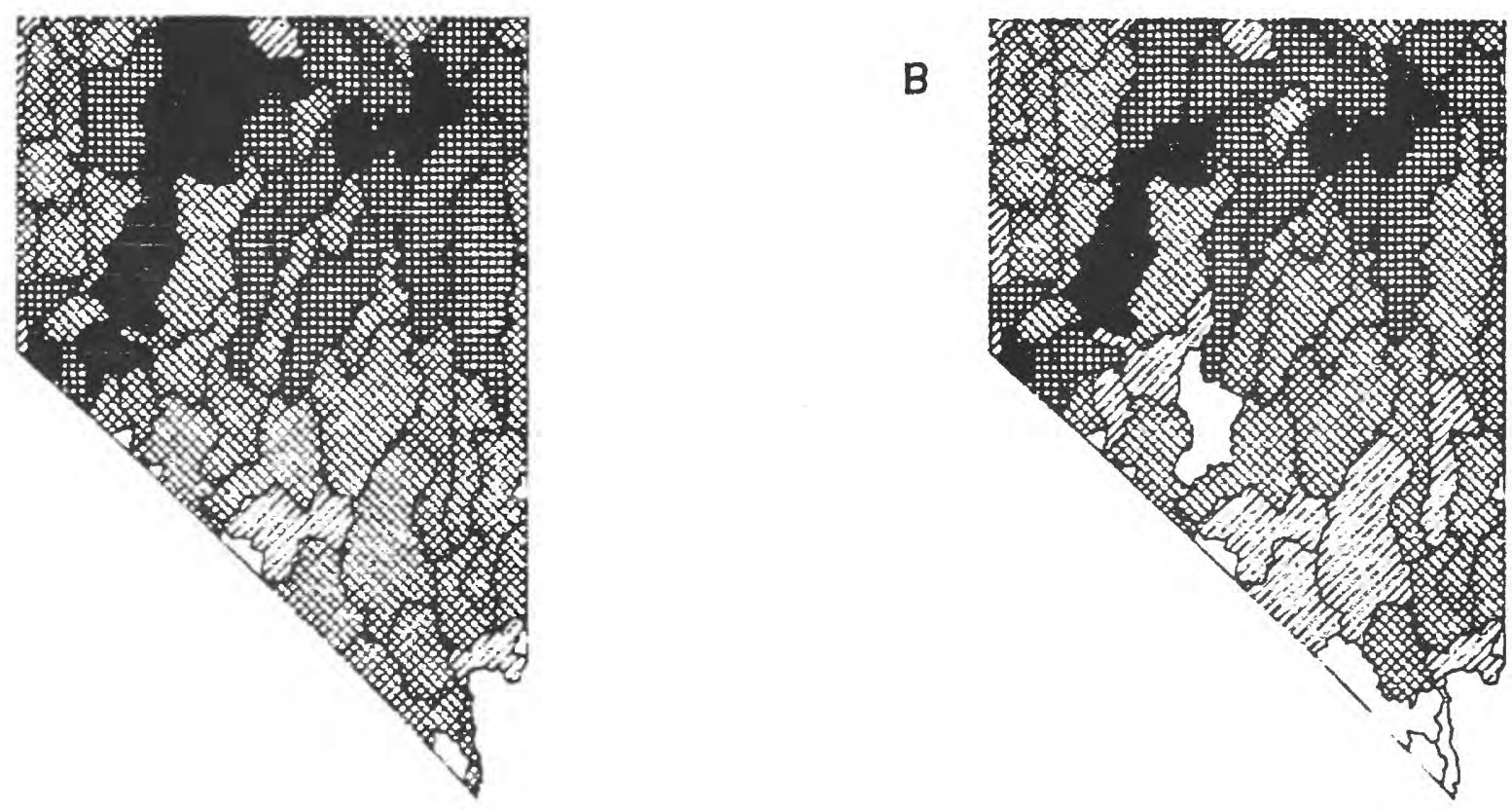

c

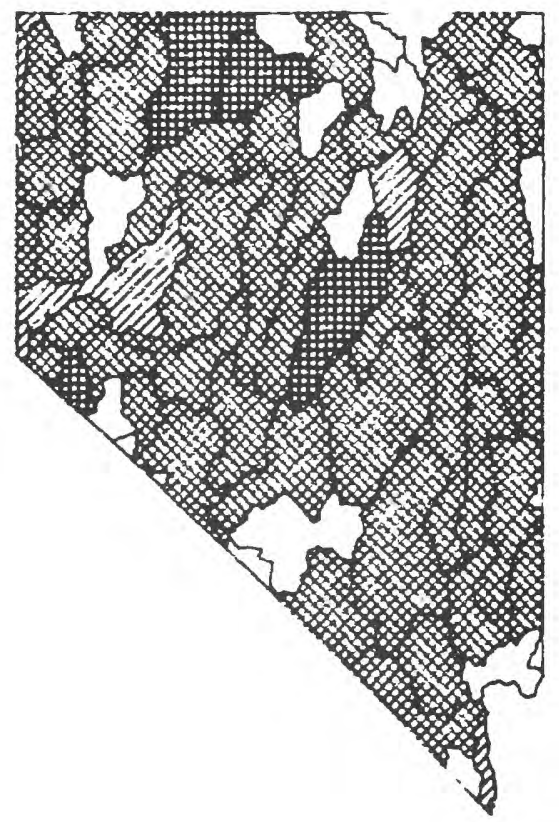

Range, in million

gallons per day

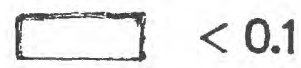

YUSYIS: $0.1-1.7$

$18-36$

37-180

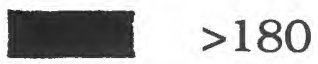

Figure 11. Water withdrawals for irrigation use, by hydrologic cataloging unit, 1985. A. Total withdrawals. B. Surface-water withdrawals. C. Ground-water withdrawals. 
(Lyman McConnell, oral commun., 1986) and U.S. Bureau of Reclamation files (1987) estimates for Carson Desert. For the remaining hydrographic areas, irrigated acreage estimates were interpreted from 1981 Landsat photos (Berggren and Harrill, 1986) and U.S. Geological Survey land-use and land-cover maps (1979, 1980a-e, 1983a-f, and 1984a-e).

Acreage estimates by crop type (alfalfa and other hay, winter and spring wheat, barley, potatoes, alfalfa seed, vegetables, orchards, and pasture) for each county were calculated by multiplying irrigated acreage by the percentage of each crop grown in the county. Percentages of crop type for each county were calculated from the average of 1982 Census of Agriculture (U.S. Bureau of the Census, 1984) and 1984 Nevada Agriculture Statistics (Nevada Crop and Livestock Reporting Service, 1985) data. Although acreage estimates by crop type are not reported, they were used to estimate acres irrigated by sprinklers and by flooding, and consumptive use.

Total irrigated acres were divided into acres irrigated by sprinklers and by flooding based on the comments received in the Crop and Water Surveys, and the pumpage inventories made by NDWR for the hydrographic areas where they were available. For other hydrographic areas, the percentage of sprinkler and flood irrigation by county and by crop type from 1984 census data for Nevada farms larger than 5,000 acres (U.S. Bureau of the Census, 1986b, p. 55-73) was multiplied by acreage estimates by county and crop type and the results were summed. The percentage of area irrigated by sprinklers ranged from 4 percent for Carson City to 21 percent for Humboldt County (percentages do not match values in table 13 because of rounding).

Use of treated wastewater was calculated from irrigated acreage and discharge location and amounts estimated by treatment-plant personnel.

Average consumptive-use rates were estimated by the Blaney-Criddle method for each crop type in each county for more than 25 locations in Nevada (U.S. Soil Conservation Service, 1985). Estimated rates ranged from 1.4 acre-ft/acre for vegetables grown in Douglas County to 4.6 acre-ft/acre for alfalfa and other hay grown in Clark County. Average consumptive use rates multiplied by acres irrigated by county and crop type equals the consumptive use listed in tables 12 and 13.
Estimates of conveyance losses were based on very few data. Conveyance losses are the result of water in transit leaking from a pipe, canal, conduit, or ditch, or lost by evaporation. The amount of water applied to a field equals consumptive use plus irrigation return flow. The amount of water withdrawn for irrigation equals the amount of water applied to a field plus conveyance losses. Three equations used to calculate conveyance loss are:

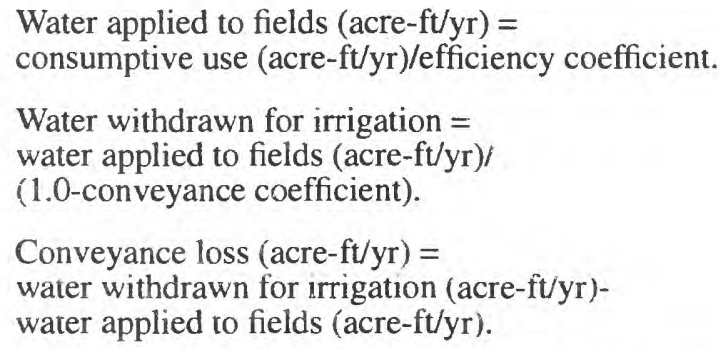

Water applied to fields (acre-ft/yr) = consumptive use (acre-ft/yr)/efficiency coefficient.

Water withdrawn for irrigation $=$ water applied to fields (acre-ft/yr) $/$ (1.0-conveyance coefficient).

Conveyance loss (acre- $\mathrm{ft} / \mathrm{yr})=$ water withdrawn for irrigation (acre-ft/yr)water applied to fields (acre-ft/yr).

Efficiency and conveyance coefficients were estimated in 1975 for the 14 Nevada hydrographic regions or basins (James R. Harrill, U.S. Geological Survey, written commun., 1976). These coefficients are rough estimates based on general assumptions that the most efficient irrigation systems use sprinklers to apply ground water withdrawn within the area being irrigated, and that the least efficient irrigation systems flood fields with surface water that has been diverted for a long distance through unlined irrigation ditches and canals. Because the use of ground water and sprinklers increased from 1975 to 1985 , the efficiency and conveyance coefficients were increased 5 percent from the values used in 1975. Estimated efficiencies averaged 68 percent and ranged from 55 percent for the Snake River Basin to 80 percent for the Death Valley Basin. Estimated conveyance coefficients averaged 14 percent and ranged from 3 percent for the Death Valley Basin to 56 percent for the Snake River Basin.

Estimates of water withdrawn for irrigation were divided by source on the basis of estimates of percentage of ground- and surface-water withdrawals. Where available, ground-water-pumpage data were used. For the remaining areas, estimates of the source of water used for irrigation were based on the shape of fields (round fields were assumed to be irrigated by pivot irrigation systems supplied by ground water), proximity to perennial streams and irrigation ditches, and ancillary information. Distribution of ground- and surface-water withdrawals are least accurate in areas irrigated by surface water in wet to normal years and by a combination of surface water and supplemental ground water in dry 
years, and in areas irrigated by surface water in wet years that are left fallow in years when no surplus water is available.

\section{Nonirrigation Agriculture}

Nonirrigation agriculture water use, which includes water for livestock watering, feed lots, dairy operations, and fisheries, was $26 \mathrm{Mgal} / \mathrm{d}$ in 1985 . This use accounts for 0.7 percent of the total offstream water withdrawals in Nevada. Surface water was the source for 77 percent $(20 \mathrm{Mgal} / \mathrm{d})$ of these withdrawals (fig. 12A). Nearly 75 percent of the water withdrawn was returned for downstream users (fig. 12B).

Water withdrawals were highest in the Central Region, Colorado River Basin, Great Salt Lake Basin, and Truckee River Basin (fig 13A), each of which has a fish hatchery that withdraws surface water (fig. 13B). Ground-water withdrawals for this category are shown in figure $13 \mathrm{C}$. Withdrawal data for nonirrigation agriculture are listed by hydrologic cataloging unit in table 14 and by county in table 15 .

Most of the livestock raised in Nevada are cattle. Withdrawals for livestock are the sum of livestock drinking water, service water (used for cleaning animal areas and equipment), and conveyance losses. Estimated withdrawals for livestock watering, feed lots, and dairy operations were $12 \mathrm{Mgal} / \mathrm{d}$.

The following 12 fishery operations withdrew 14 $\mathrm{Mgal} / \mathrm{d}$, of which more than 90 percent was surface water: Lake Mead, Dunn, David-Cook, Lahontan, Captain Numana, and Gallagher Fish Hatcheries; Spring Creek and Washoe Rearing Stations; Smith Valley and Kingston Canyon Holding Ponds; and Winnemucca Redistribution Station and Pyramid Lake Operations. Cutthroat and rainbow trout are the primary fish raised in the State.

Since 1975, estimated withdrawals for livestock watering, feed lots, and dairy operations have remained the same. Also, total estimated withdrawals for fishery operations have remained the same since 1975; at that time, this use was reported in the self-supplied industrial category (Murray and Reeves, 1977, p. 22).

Livestock population estimates for 1985 are 580,000 beef cattle (including 280,000 range cattle), 17,000 dairy cattle, 14,000 hogs and pigs (average of statistics reported by Nevada Department of Agriculture, 1986, and U.S. Bureau of the Census, 1984), 110,000 sheep, 26,000 chickens, 260 turkeys
(U.S. Bureau of the Census, 1984), and 55,000 horses. The estimated number of horses was the sum of horses on farms (U.S. Bureau of the Census, 1984), wild horses (U.S. Bureau of Land Management, 1986), and an estimate of privately owned horses not on farms. Drinking and service-water use rates per animal are 10 $\mathrm{gal} / \mathrm{d}$ for beef cattle, $20 \mathrm{gal} / \mathrm{d}$ for dairy cattle, $6 \mathrm{gal} / \mathrm{d}$ for range cattle, $3 \mathrm{gal} / \mathrm{d}$ for hogs and pigs, $2 \mathrm{gal} / \mathrm{d}$ for sheep, $0.04 \mathrm{gal} /$ day for chickens, $0.06 \mathrm{gal} / \mathrm{d}$ for turkeys, and $10 \mathrm{gal} / \mathrm{d}$ for horses (Jon O. Nowlin, U.S. Geological Survey, written commun., 1976). Conveyance losses are assumed to be equal to drinking- and service-water requirements. Livestock consumptive-use rates were estimated to equal 100 percent of drinking- and service-water requirements plus 100 percent of conveyance losses for wells, 80 percent for springs, and 30 percent for surface water. Because current Statewide data are not available on the source of water for livestock, the same distribution of well, spring, and surface water reported for 1969 (Smales and Harrill, 1971, p. 30) and used in 1975 (Jon O. Nowlin, U.S. Geological Survey, written commun., 1976) also was used in 1985. Livestock water-use estimates were compiled by county and then apportioned to hydrologic cataloging units on the basis of the percentage of irrigated crop and pasture within cataloging units in each county.

The Nevada Department of Wildlife, Pyramid Lake Fisheries, and Lahontan Fish Hatchery provided estimates of withdrawals for fisheries. Estimated consumptive use averaged 2 percent of fishery water withdrawals.

\section{Industrial}

Industrial water use includes water for manufacturing and construction. Estimated use in 1985 was $16 \mathrm{Mgal} / \mathrm{d}$. Self-supplied industrial withdrawals furnished $10 \mathrm{Mgal} / \mathrm{d}$ (62 percent) and public-supply systems delivered 6.3 Mgal/d (38 percent; fig. 14A). About 76 percent $(7.8 \mathrm{Mgal} / \mathrm{d})$ of the self-supplied withdrawals were surface water. About 20 percent (3.2 Mgal/d) of the water was consumptively used (fig. 14B).

Statewide, industrial use of water (including public-supply deliveries) is the smallest use category, accounting for less than 0.5 percent of all offstream withdrawals. Only 6 of the 72 hydrologic cataloging units in Nevada had self-supplied withdrawals for industrial use greater than the minimum reporting level 


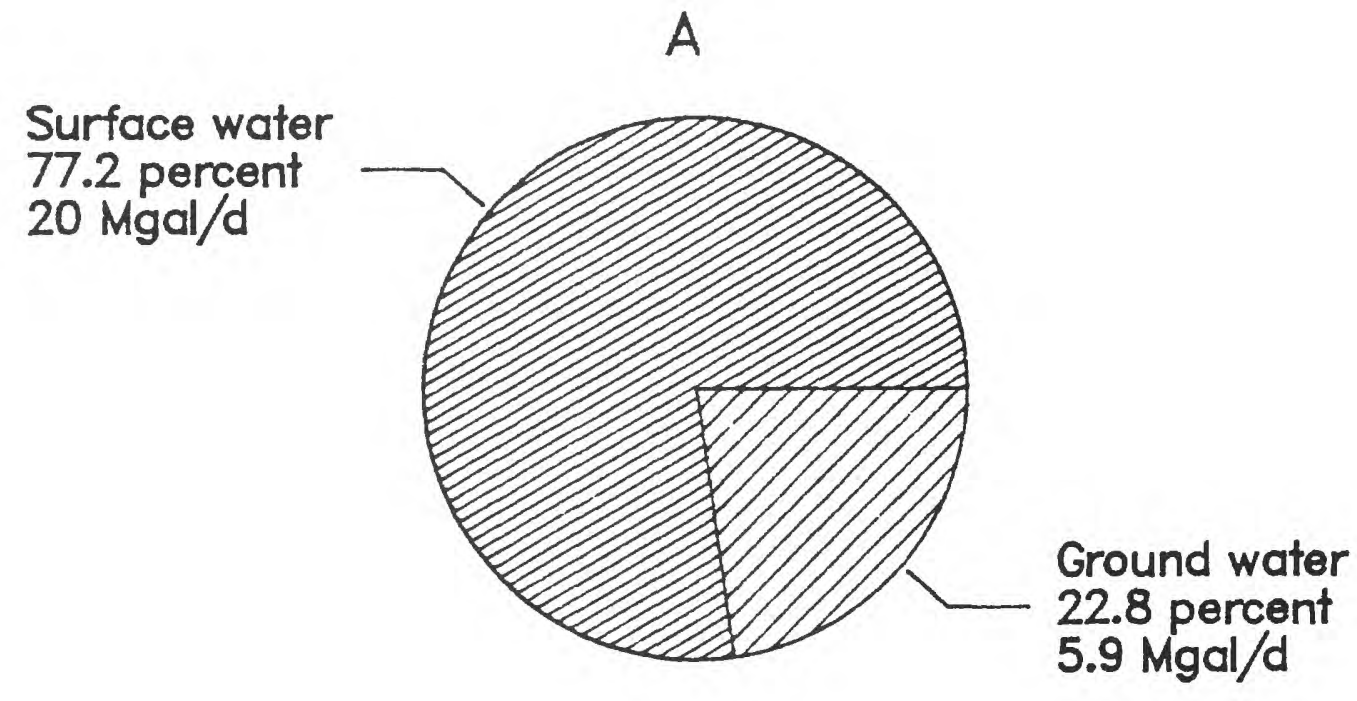

B

Return flow

74.2 percent $19 \mathrm{Mgal} / \mathrm{d}$

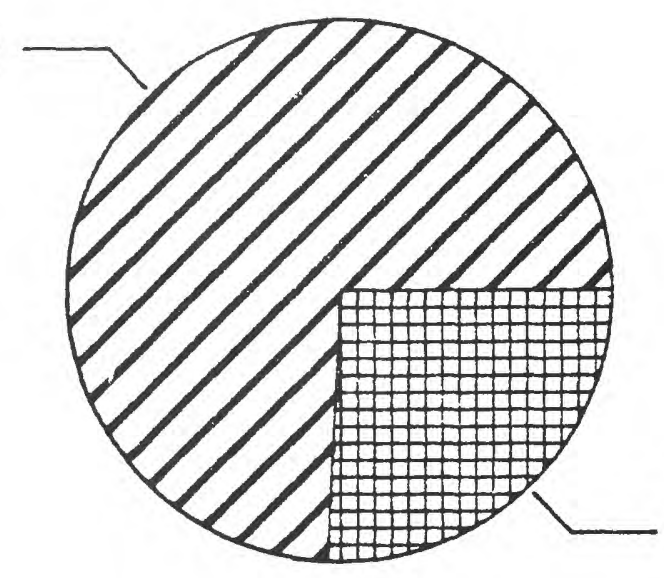

Consumptive use 25.8 percent $6.6 \mathrm{Mgal} / \mathrm{d}$

Figure 12. Nonirrigation agriculture water use, 1985. A. Withdrawals by source. B. Disposition by type. Abbreviation: Mgal/d, million gallons per day. 
A

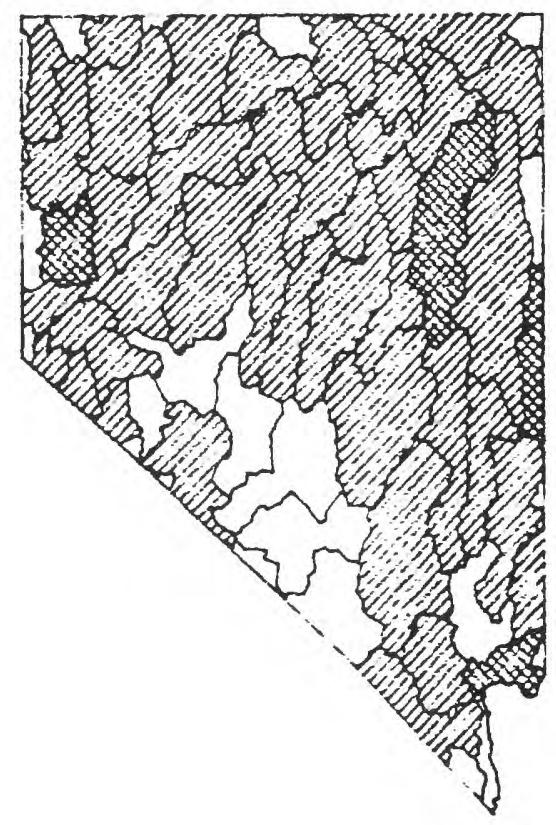

C

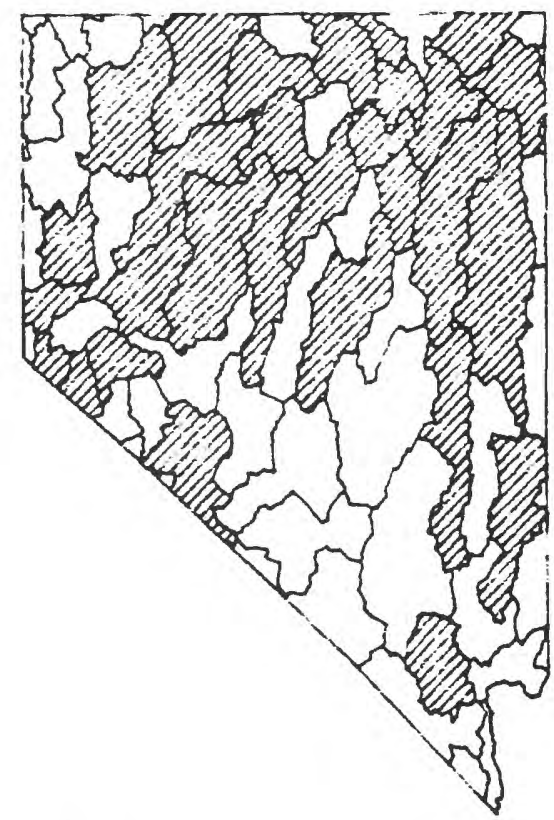

B

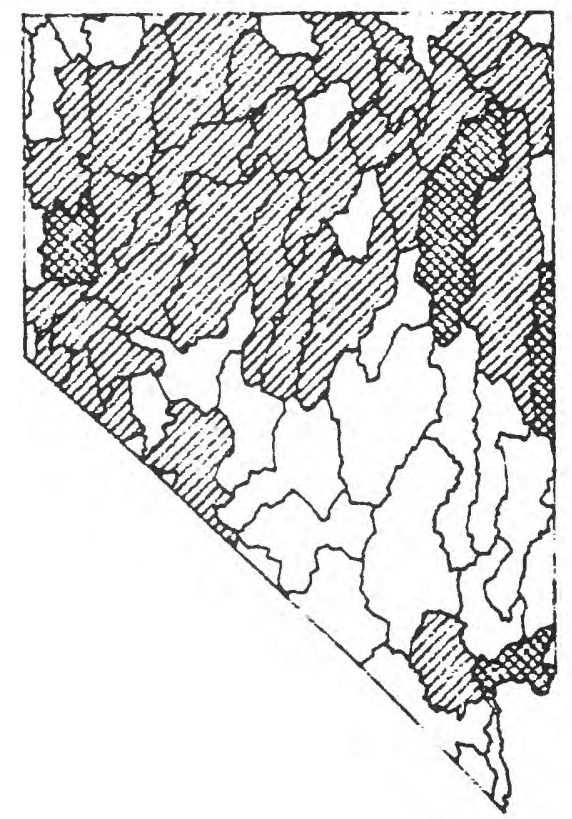

EXPLANATION

Range, in million

gallons per day

$\square<0.1$

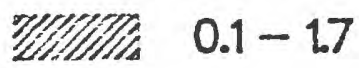

$1.8-36$

Figure 13. Water withdrawals for nonirrigation agriculture use, by hydrologic cataloging unit, 1985. A. Total withdrawals. B. Surface-water withdrawals. C. Ground-water withdrawals. 

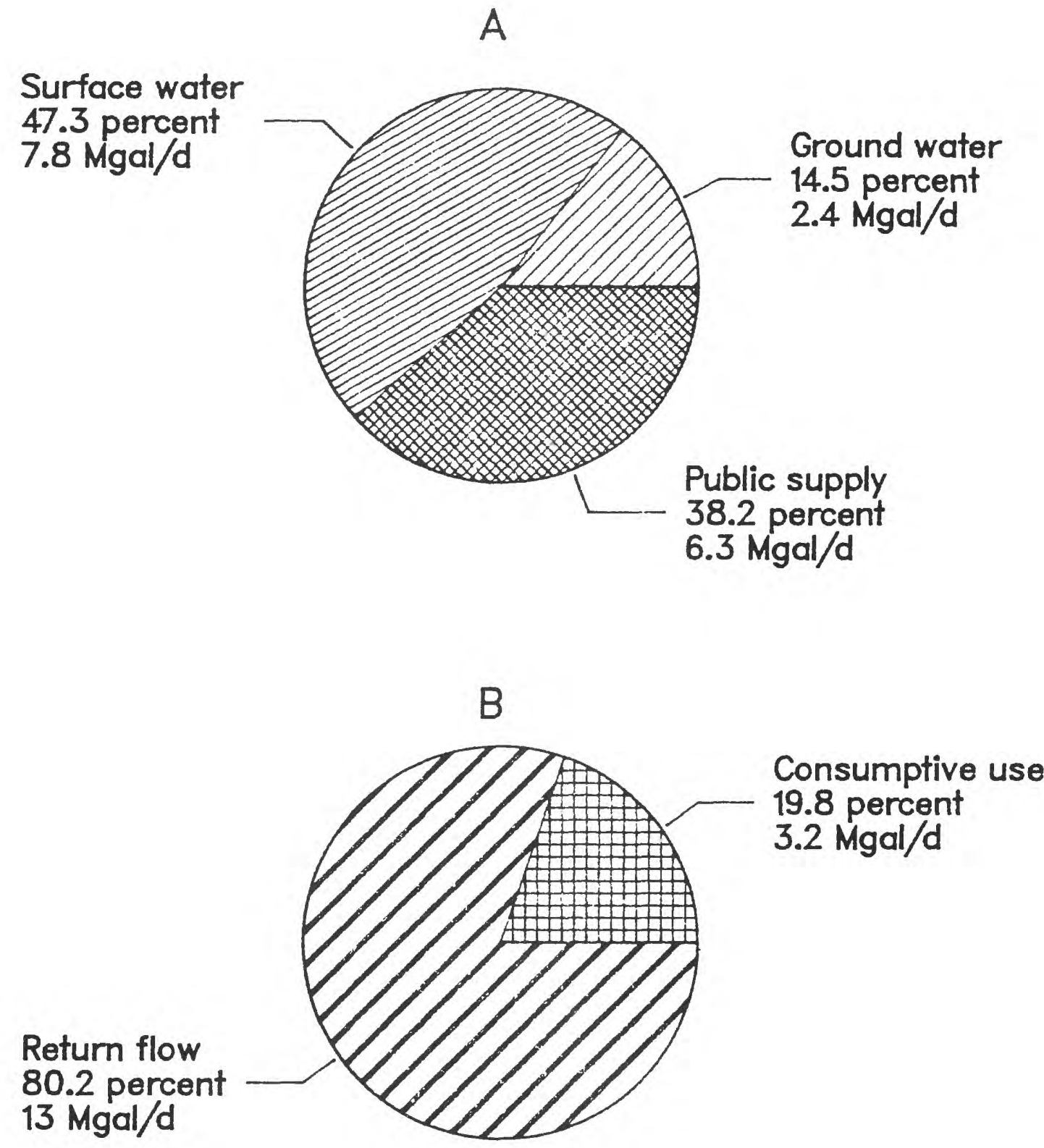

Figure 14. Industrial water use, 1985. A. Withdrawals, by source and deliveries. B. Disposition by type. Abbreviation: Mgal/d, million gallons per day. 
(0.1 Mgal/d), as shown in figure 15A. Table 16 lists industrial water-use data by hydrologic cataloging unit and table 17 lists the same data by county.

The largest self-supplied industrial water withdrawals were in Las Vegas Valley (map number 7), where surface water was the primary source, as shown in figures $15 \mathrm{~B}$ and $15 \mathrm{C}$. More than 79 percent of all self-supplied industrial withdrawals were in Las Vegas Valley. Statewide, Las Vegas Valley accounted for 57 percent of all industrial water use from both self-supplied sources and public-supplied deliveries.

The 1975 and 1980 estimates of industrial water use (133 and $149 \mathrm{Mgal} / \mathrm{d}$, respectively) included selfsupplied commercial, mining, golf courses and fish hatcheries. Using the current standard for the industrial category, the estimates for self-supplied withdrawals have increased about five times since 1975.

Data on industrial water use in Las Vegas Valley were obtained from water-supply companies and the ground-water pumping inventory by NDWR for the valley. In all other areas, values used were from the water-supply companies that report industrial deliveries. Employment figures from the U.S. Bureau of the Census (1985a), a listing of industries in Nevada (Nevada Commission on Economic Development, 1985), and water-use figures from the U.S. Bureau of the Census (1986a) were used to estimate industrial water use. Little information was available on selfsupplied industrial withdrawals outside of Las Vegas Valley.

\section{Mining}

Mining water use includes water for the extraction of naturally occurring materials, milling, and other mining activities. In Nevada, the primary uses are for mineral extraction and concentration. Water withdrawal for mining during 1985 was $30 \mathrm{Mgal} / \mathrm{d}$; all water was self supplied. Approximately 91 percent $(27 \mathrm{Mgal} / \mathrm{d})$ of the water used was from ground-water sources (fig. 16A), and more than 86 percent of the water withdrawn was consumptively used (fig. 16B).

Although the economy and the history of Nevada are closely related to mining, this category accounted for only 0.8 percent of the total offstream withdrawals in 1985. The distribution of water withdrawals for mining is shown by hydrologic cataloging unit in figure 17 . Table 18 lists mining water use by hydro- logic cataloging unit, and table 19 presents these data by county. Clayton Valley (see map number 49 ) led the State in 1985 mining withdrawals $(9.8 \mathrm{Mgal} / \mathrm{d})$.

Mining was the only category to use reportable amounts of saline water, $8.4 \mathrm{Mgal} / \mathrm{d}$, in 1985 . Most of the saline ground water withdrawn in the State is pumped from a playa in Clayton Valley; this brine water evaporates and leaves behind valuable salts. The most profitable element being extracted by the evaporation process was lithium, in 1989.

Withdrawals for mining were included in the industrial category for the 1975 and 1980 national estimates. Using the current standard for the mining category, water use has decreased by 36 percent since 1975 . Although gold and silver mining have increased, the closing of three large copper mines, which used about $25 \mathrm{Mgal} / \mathrm{d}$ in 1975 (Jon O. Nowlin, U.S. Geological Survey, written commun., 1976), is the primary reason for this decrease.

The number of active mines in 1985, their locations, number of people employed, commodities mined, and processes used were obtained from the Directory of Nevada Mine Operations (Nevada Division of Mine Inspection, 1986). About 80 mines, which accounted for more than 80 percent of the people working in mines, were directly surveyed about their water use. Estimates of water use by commodity, process, and scale of mining operation were applied to nonsurveyed mines on the basis of surveyed data. General water use estimates, by commodity or by method of mineral extraction, were used for guidance where no other information was available (U.S. Bureau of the Census, 1985b; Baker and others, 1973; Holmes, 1966, p. 60).

\section{Thermoelectric Power}

The thermoelectric power category includes water used in the production of electric power generation from fossil fuel, geothermal sources, and nuclear sources. Nevada has 11 thermoelectric power plants7 are fossil-fuel powered and 4 are geothermal powered. No nuclear-powered thermoelectric power plants are in the State. In 1985, water for thermoelectric power generation represented less than 2 percent of total ground-water use and less than 1 percent of total offstream surface-water use in Nevada. Withdrawals and deliveries were $26 \mathrm{Mgal} / \mathrm{d}$, and power production was $12,000 \mathrm{GWh}$. Self-supplied ground water was the 
A

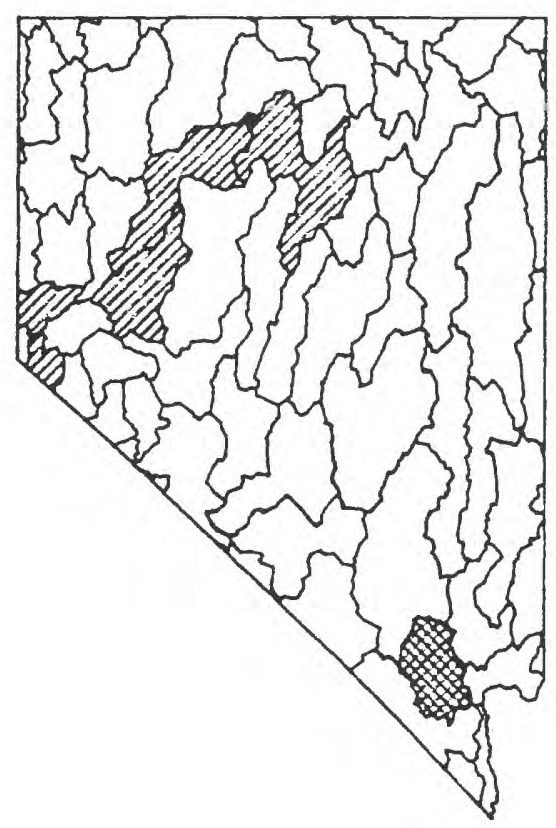

C

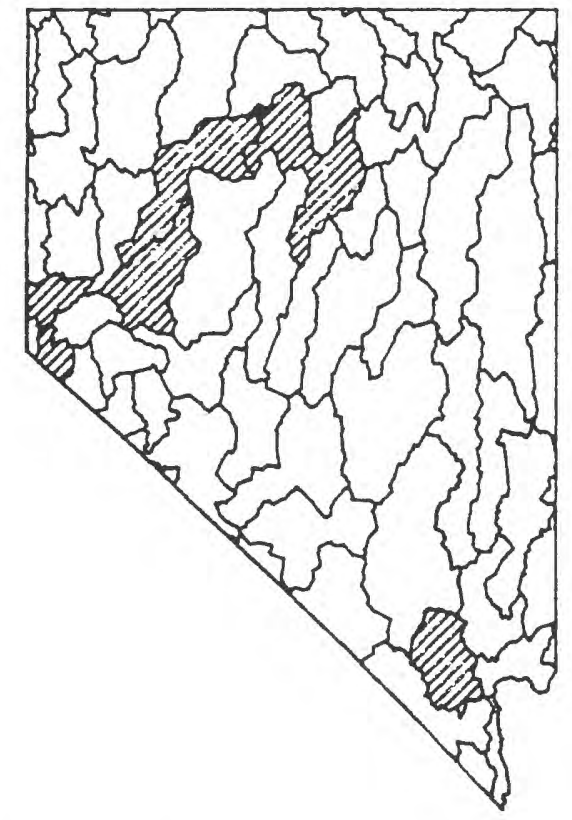

B

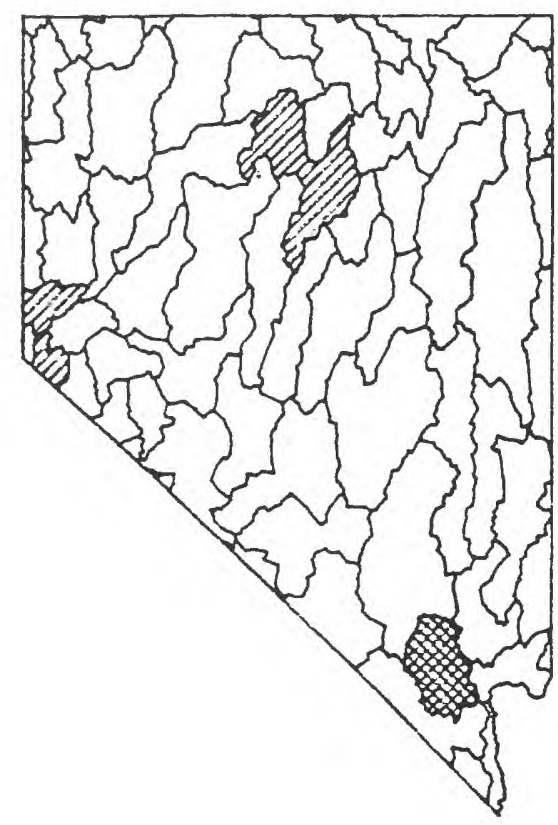

\section{EXPLANATION}

Range, in million

gallons per day

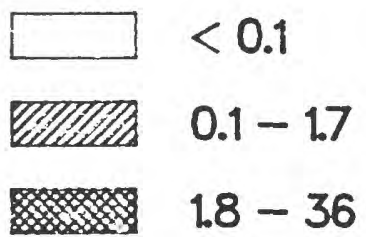

Figure 15. Water withdrawals for self-supplied industrial use, by hydrologic cataloging unit, 1985. A. Total withdrawals. B. Surface-water withdrawals. C. Ground-water withdrawals. 

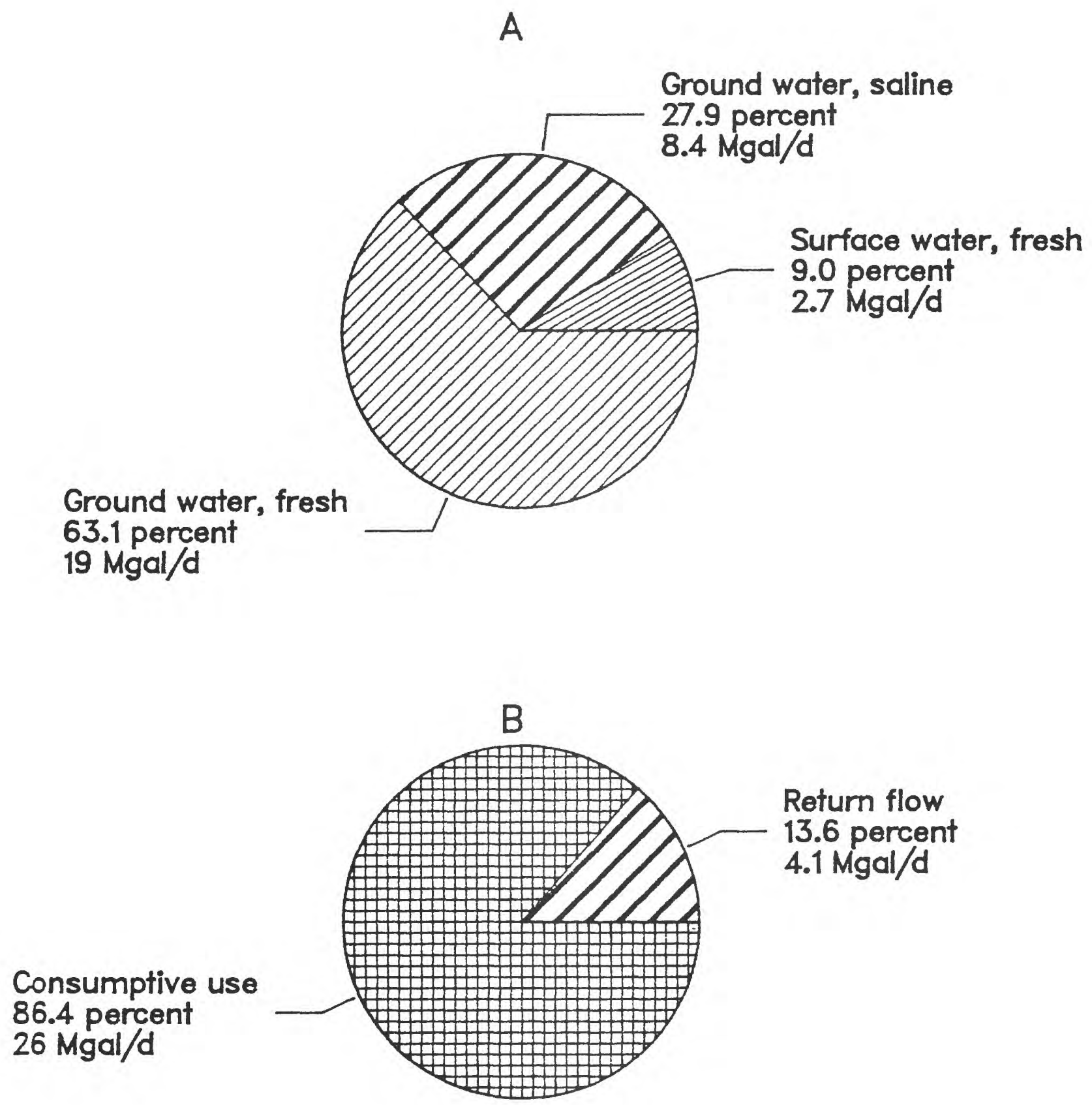

Figure 16. Mining water use, 1985. A. Withdrawals by source. B. Disposition by type. Abbreviation: Mgal/d, million gallons per day. 
A
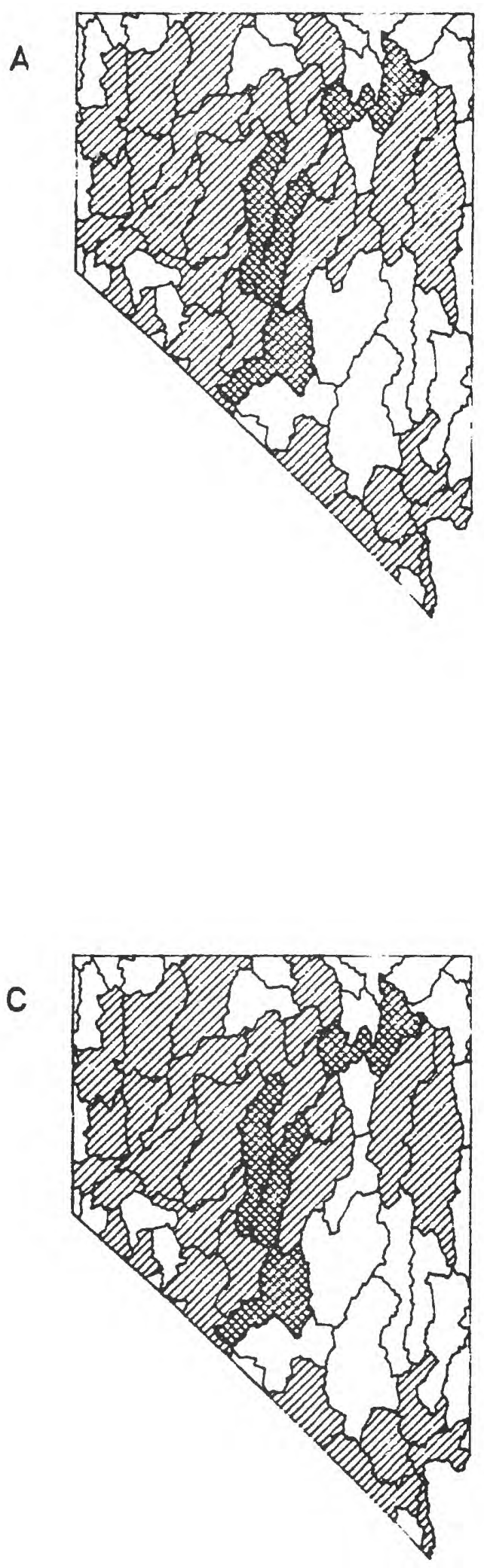

B

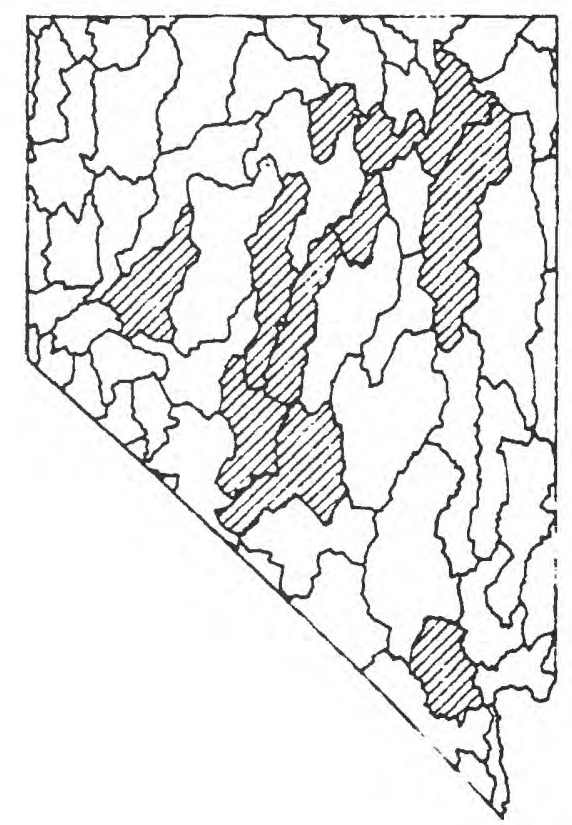

\section{EXPLANATION}

Range, in million

gallons per day

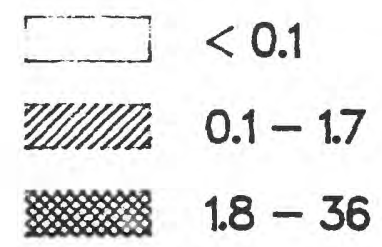

Figure 17. Water withdrawals for mining use, by hydrologic cataloging unit, 1985. A. Total withdrawals. B. Surfacewater withdrawais. C. Ground-water withdrawals. 
largest source of water for power generation, furnishing $16 \mathrm{Mgal} / \mathrm{d}$, followed by self-supplied surface water at $7.5 \mathrm{Mgal} / \mathrm{d}$, and public-supplied water about 2.5 $\mathrm{Mgal} / \mathrm{d}$; (fig. 18A). Approximately 92 percent of the water withdrawn was consumptively used (fig. 18B).

Figure 19 shows the distribution and ranges of water withdrawals for thermoelectric-power generation by hydrologic cataloging unit. The largest use of surface water for thermoelectric-power generation was in the Havasu-Mohave Lakes hydrologic cataloging unit (map number 8), as shown in figure 19B. Thermoelectric water-use and power-generation data are listed by hydrologic cataloging unit in table 20 and by county in table 21.

Fossil-fuel power plants operating in 1985, listed in decreasing order of water withdrawals and deliveries, were Reid-Gardner, Mohave, North Valmy, Fort Churchill, Tracy, Clark, and Sunrise. The three largest plants accounted for 86 percent of water withdrawn and 95 percent of power generated by fossil-fuel plants.

Wabuska, the oldest geothermal plant in Nevada, began producing power in 1983 (Scott McDaniels, Nevada Division of Minerals, oral commun., 1986). Desert Peak, Beowawe, and Steamboat Springs geothermal plants produced power for the first time in December 1985. The values presented in tables 20 and 21 underestimate annual water use or power production because these plants were not in full operation.

From 1975 to 1985 , the amount of water withdrawn for thermoelectric-power generation decreased 70 percent. In 1975, withdrawals for power generation were $95 \mathrm{Mgal} / \mathrm{d}$ (Murray and Reeves, 1977, p. 28) compared with $26 \mathrm{Mgal} / \mathrm{d}$ in 1985 . During the same 10-year period, consumptive use increased from $22 \mathrm{Mgal} / \mathrm{d}$ (23 percent) to $24 \mathrm{Mgal} / \mathrm{d}$ (92 percent). These changes are primarily the result of a power plant on the Truckee River switching from once-through to closed-loop cooling in June 1977.

Water-use estimates for fossil-fuel power plants were obtained directly from each power plant in the State. Additional information from the U.S. Department of Energy (written commun., 1986) and the Hanford Engineering Development Laboratory (written commun., 1986) were used. The operator of each geothermal plant was also surveyed; however, one plant had not installed meters in 1985 and another plant would not publicly release its data. The geothermal water-use reports for the plants at Beowawe and Desert Peak are filed with the U.S. Bureau of Land Management; however, these reports are confidential, so the water withdrawals at these two plants were estimated. Water-withdrawals were not estimated for several geothermal wells tested in 1985 .

\section{Total Offstream Water Use}

Total withdrawals (fresh and saline) during 1985 were estimated to be $3,700 \mathrm{Mgal} / \mathrm{d}$ for all offstream water-use categories (public supply, domestic, commercial, irrigation, nonirrigation agriculture, industrial, mining, and thermoelectric power), which is nearly 6 percent higher than the withdrawals estimated for 1975 (Murray and Reeves, 1977, p. 30). Surface-water withdrawals were $2,800 \mathrm{Mgal} / \mathrm{d}$ (fig. 20A) during 1985 (the same amount as in 1975) and ground-water withdrawals were $920 \mathrm{Mgal} / \mathrm{d}$ (a 33-percent increase from 1975).

The distribution of water withdrawals by category is shown in figure 20B. Irrigation is the dominant use in the State, using nearly 90 percent of the water withdrawn. About 50 percent of the water is consumptively used (fig. 20C) and about 30 percent is returned for downstream users.

Total offstream withdrawals by hydrologic cataloging unit are shown in figure 21 and listed in table 22; similar information by county is presented in table 23 . The Upper Humboldt (map number 15) and the Carson Desert (map number 34) hydrologic cataloging units had the greatest withdrawals (310 Mgal/d each). The data in table 23 indicate that Elko County had the greatest withdrawal (940 Mgal/d) and accounted for about 25 percent of the total water withdrawn in Nevada.

A summary of water withdrawals by water-use category is listed by hydrologic cataloging unit and county in tables 24 and 25 , respectively. Surface- and ground-water withdrawals are listed separately in tables 26-29.

\section{INSTREAM WATER USE}

Instream water in Nevada is used for hydroelectric-power generation, fish and wildlife, and recreation; however, estimates of instream water use were made only for power generation. Unlike the other instream uses, the amount of water passed through turbines for hydroelectric-power generation can be measured. 


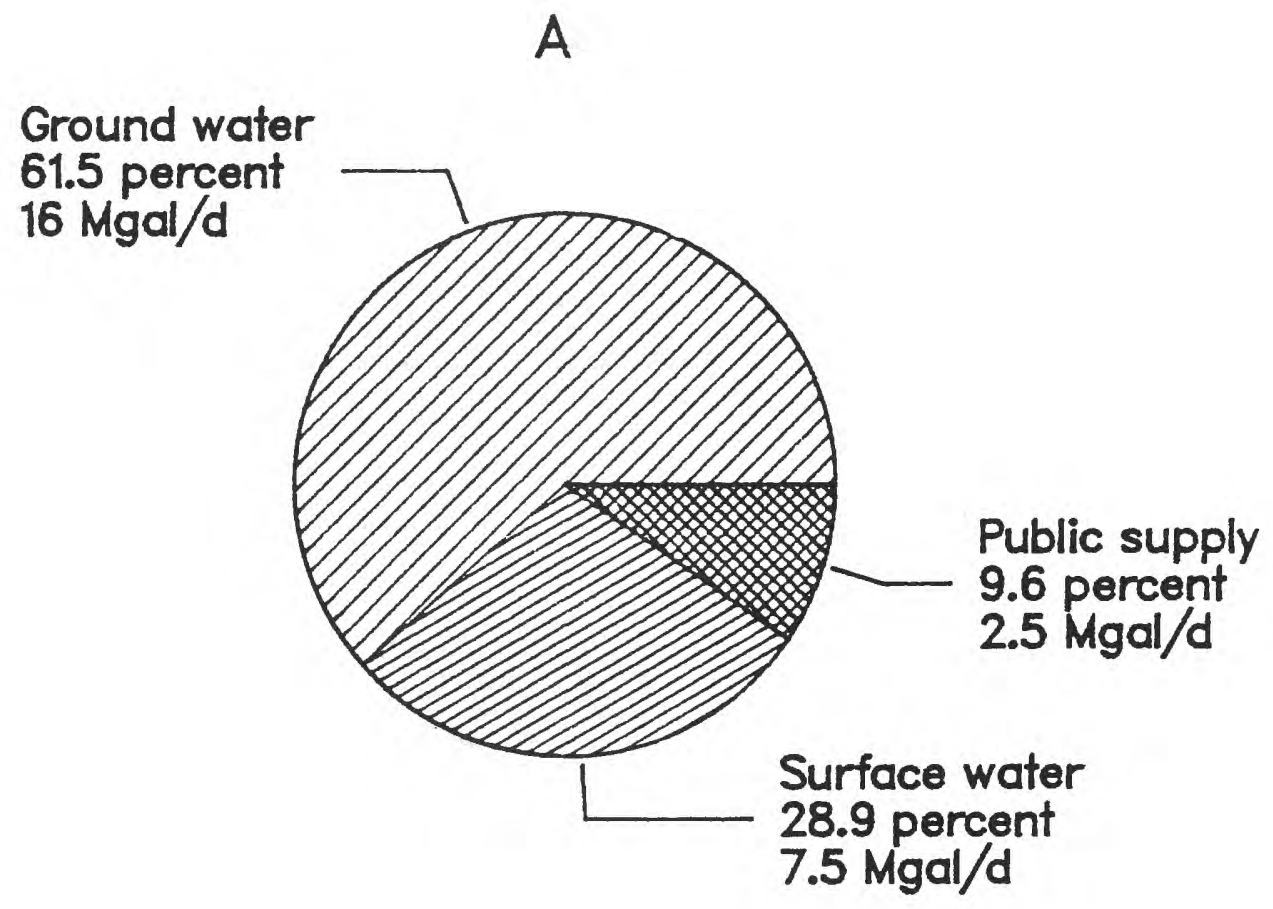

Consumptive use 92.3 percent $24 \mathrm{Mgal} / \mathrm{d}$

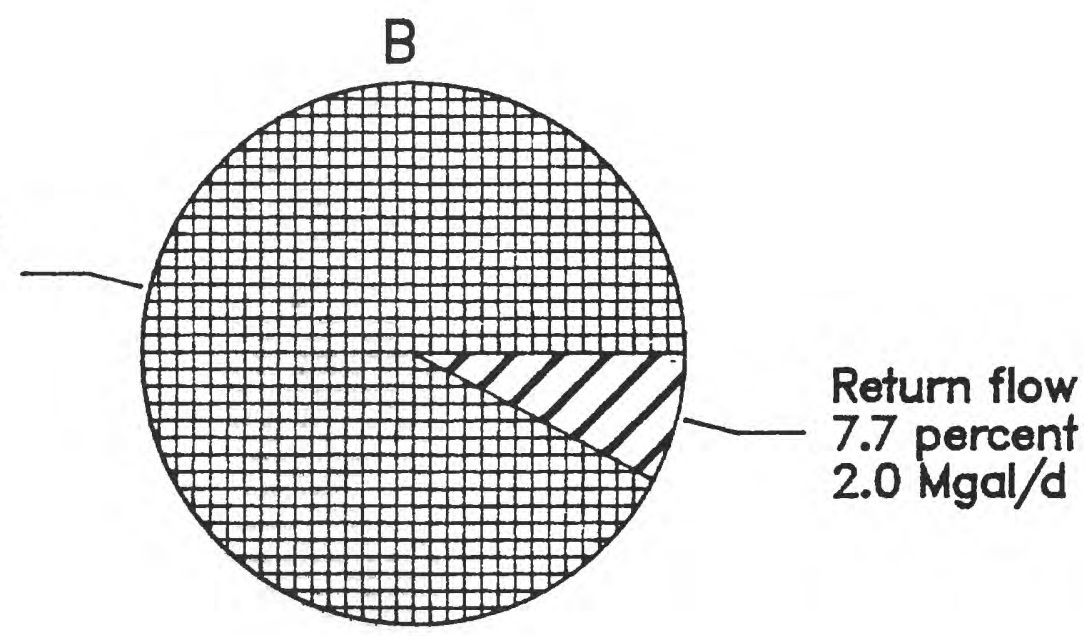

Figure 18. Thermoelectric power water use, 1985. A. Withdrawals by source and deliveries. B. Disposition, by type. Abbreviation: Mgal/d, million gallons per day. 
A
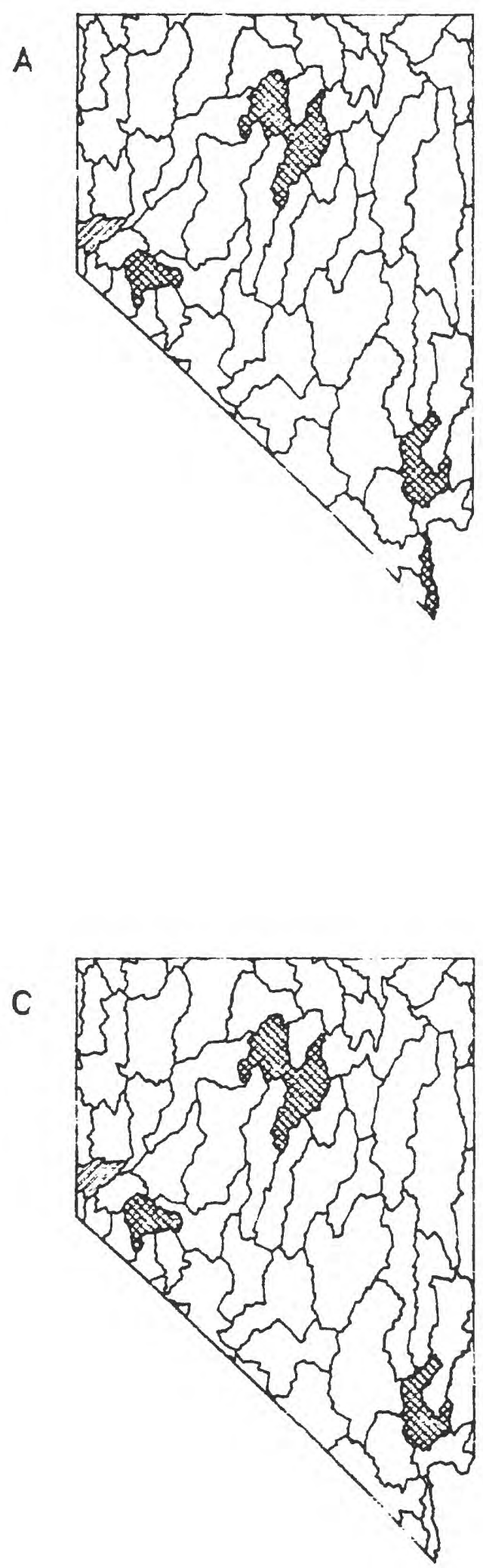

B

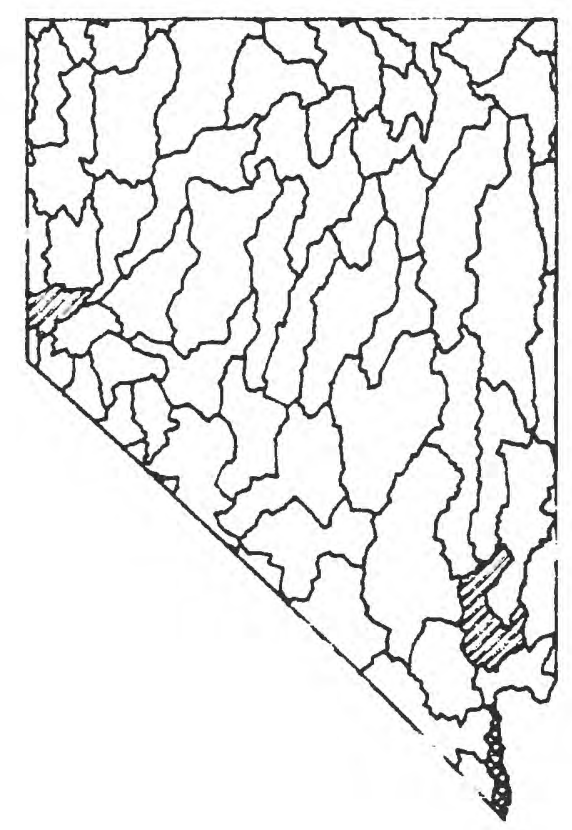

EXPLANATION

Range, in million

gallons per day

$[\square<0.1$

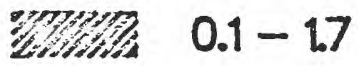

$18-36$

Figure 19. Self-supplied water withdrawals for thermoelectric power use, by hydrologic cataloging unit, 1985. A . Total withdrawals. B. Surface-water withdrawals. C. Ground-water withdrawals. 

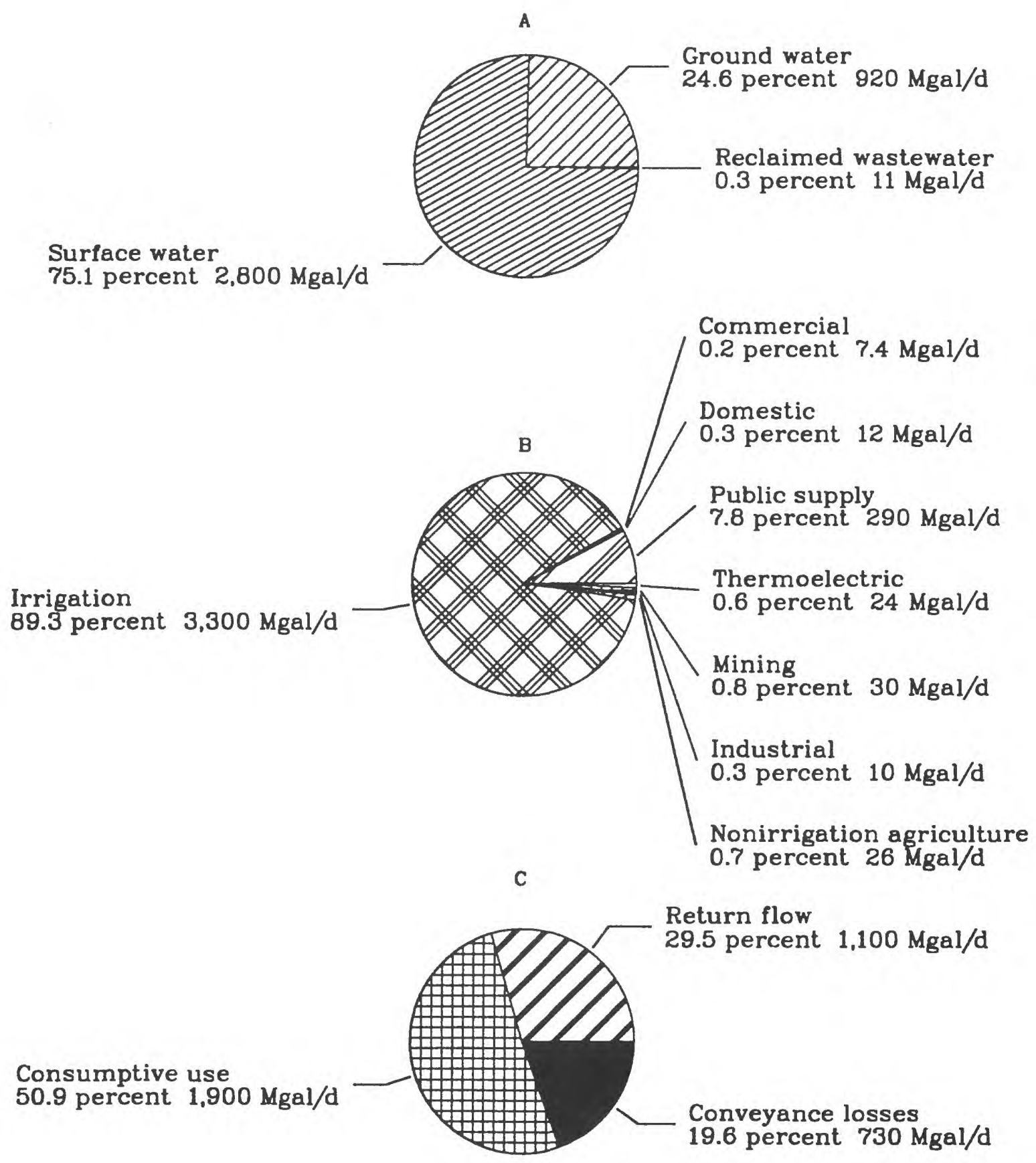

Figure 20. Total offstream water use, 1985. A. Withdrawals, by source. B. Use, by type. C. Disposition, by type. Abbreviation: Mgal/d, million gallons per day. 

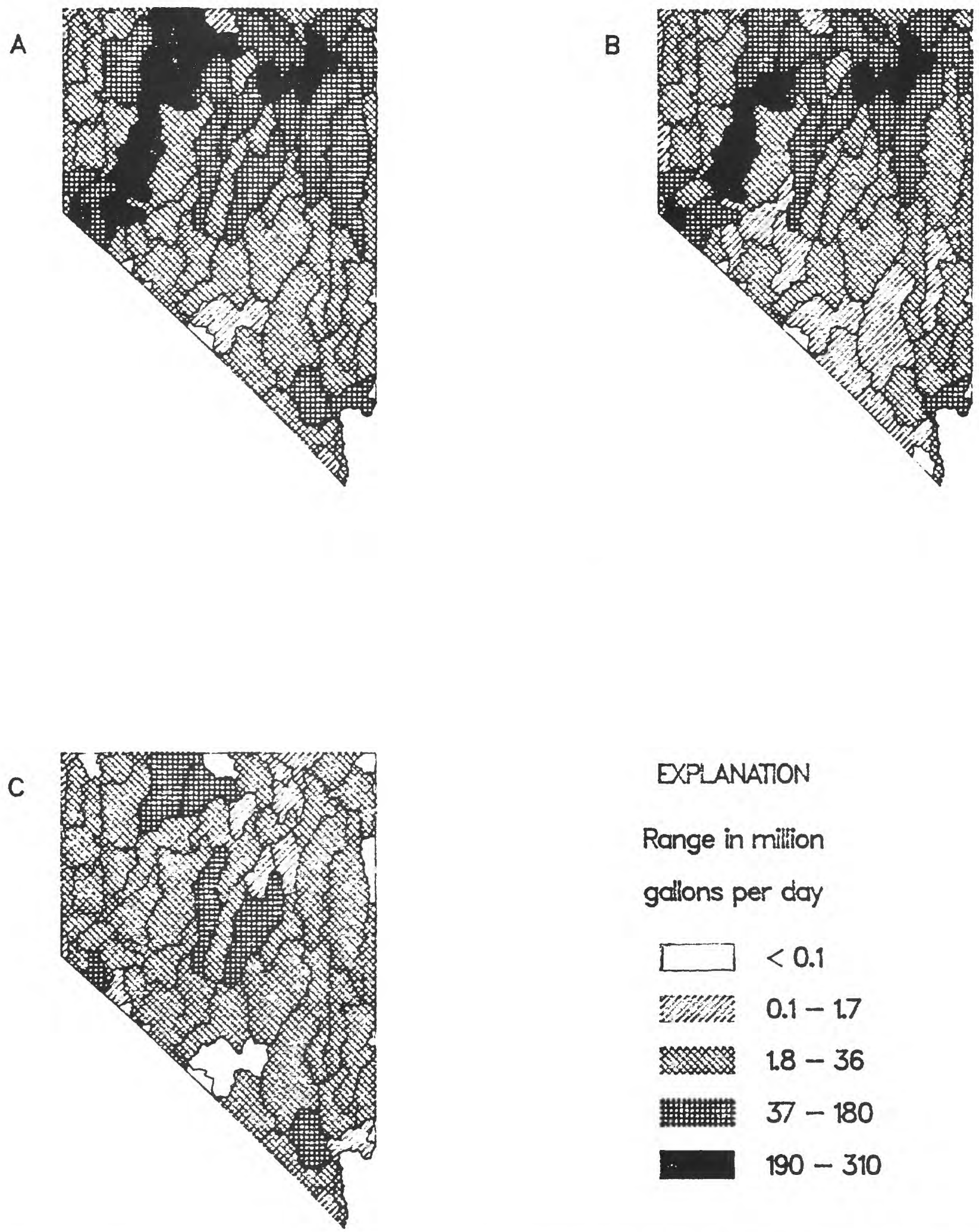

EXPLANATION

Range in million

gallons per day

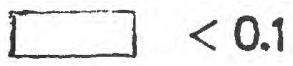

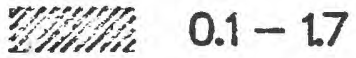

$1.8-36$

$37-180$

$\therefore \quad 190-310$

Figure 21. Total offstream water withdrawals, by hydrologic cataloging unit, 1985. A. Total withdrawals. B. Surfacewater withdrawals. C. Ground-water withdrawals. 


\section{Hydroelectric Power}

Hydroelectric-power generation water use refers to the water used in the generation of electricity at plants where turbine generators are driven by falling water. Ten hydroelectric power plants used 8,900 $\mathrm{Mgal} / \mathrm{d}$ of surface water to produce $4,350 \mathrm{GWh}$ of power in 1985. Although several small hydroelectric power plants in Nevada generate power with water that has been diverted from stream channels, all hydroelectric use is reported as instream use. Surface water is the source for hydroelectric- power generation (fig. 22A). Evaporation from stream channels, diversions, and reservoirs was not estimated. Consumption of water used for hydroelectric-power generation is negligible; therefore, return flow is assumed to be 100 percent (fig. 22B).

Only six hydrologic cataloging units have withdrawals for hydroelectric-power generation (fig. 23). Table 30 lists withdrawals and power generation by hydrologic cataloging unit, and table 31 lists this information by county. The values for Havasu-Mohave Lakes (map number 8) include the Nevada part of Hoover Dam; this is approximately 53 percent of the water used and the power generated at Hoover Dam. The Nevada part of Hoover Dam water use, 8,300 $\mathrm{Mgal} / \mathrm{d}$, accounts for 93 percent of instream use of water in Nevada. Washoe, Fleish, Farad, and Verdi hydroelectric-power plants are on the Truckee River (map number 29) and Lahontan (a) and Lahontan 26 foot-drop are on the Carson River (map number 34). Except for the Washoe plant, all hydroelectric plants on the Truckee and Carson Rivers were operating in 1985 and used $630 \mathrm{Mgal} / \mathrm{d}$ to produce $43 \mathrm{GWh}$. Four small hydroelectric plants (Bush Ranch Hydroelectric, Frank Hooper Hydroelectric Project, Leidy Creek, and Trout Creek) withdrew approximately $9 \mathrm{Mgal} / \mathrm{d}$ to produce $0.5 \mathrm{GWh}$.

Since 1975 , water use for hydroelectric-power generation in Nevada (excluding the water used at Hoover Dam) has decreased. In 1975, this category was estimated to use $880 \mathrm{Mgal} / \mathrm{d}$ (Jon O. Nowlin, U.S. Geological Survey, written commun., 1976), compared to the 1985 estimate of $640 \mathrm{Mgal} / \mathrm{d}$. It is not known what percentage of the water used at Hoover Dam in 1975 was represented by the $3,700 \mathrm{Mgal} / \mathrm{d}$ allotted to Nevada.

Hydroelectric water-use estimates were obtained directly from power companies operating hydroelectric plants in the State. Additional information from the
U.S. Department of Energy (written commun., 1986) and the Hanford Engineering Development Laboratory (written commun., 1986) also were used.

\section{WASTEWATER TREATMENT}

The wastewater-treatment category includes water released by public, industrial, and commercial wastewater-treatment facilities; however, only the quantities released from public facilities are listed in this report. In 1985,83 facilities returned $130 \mathrm{Mgal} / \mathrm{d}$ of treated wastewater. These "return" estimates include wastewater sent to evaporation ponds and other selfcontained facilities. In addition, 82 other facilities had discharge permits in 1985 (Nevada Division of Environmental Protection, written commun., 1986), of which an unknown number had treatment facilities. The distribution and amount of discharges from public wastewater-treatment-facilities (fig. 24) are similar to, but smaller than, the distribution and amount of publicsupply withdrawals (fig. 5A).

U.S. Bureau of the Census (1983, p. 30-7) data for 1980 indicate that 92.4 percent of Nevada households were served by public or private water systems and that 87.3 percent of households were served by public sewer systems. These percentages are as low as 48.4 and 41.6 percent in rural counties. The greatest wastewater-treatment releases were in Las Vegas Valley (map number 7), where the largest concentration of people live. Tables 32 and 33 list number of facilities and releases by hydrologic cataloging unit and county, respectively.

More than $11 \mathrm{Mgal} / \mathrm{d}$ of treated wastewater was used in 1985 to irrigate golf courses, pastures, and alfalfa fields (tables 12 and 13), and as cooling water at a power plant. No data on mining and industrial use of treated effluent were collected for Nevada in 1985. Ninety percent of the treated wastewater was used in Las Vegas Valley (map number 7), Carson and Eagle Valleys (map number 32), and the Elko Segment (map number 15).

Estimated municipal wastewater-treatment releases have increased 131 percent since 1979 , from $99 \mathrm{Mgal} / \mathrm{d}$ processed by 60 plants (Nevada Division of Water Planning, 1979, p. 117-121) to $130 \mathrm{Mgal} / \mathrm{d}$ processed by 83 plants in 1985 (tables 32 and 33). Estimated use of treated effluent was $11 \mathrm{Mgal} / \mathrm{d}$ in 1975 (Murray and Reeves, 1977, p. 30) and in 1985 (Solley and others, 1988, p. 59); however, definitions 
of categories for which data were collected in Nevada changed. During this 10-year period (1975-85), use of treated wastewater for irrigation increased approximately 160 percent. Wastewater-treatment releases were not estimated for water-use reports prior to 1985 .

The number of public sewage-treatment facilities (83) and other treatment facilities (82) were estimated from lists of sewage-treatment facilities and of discharge permit holders excluding sewage-treatment facilities (Nevada Division of Environmental Protection, written commun., 1986). Estimates of design capacity of sewage-treatment plants, number and type of connections served, discharge location and volumes, and number of acres irrigated with treated wastewater were collected from approximately 70 percent of the public sewage-treatment facilities. The accuracy of discharge measurements reported for larger treatment plants was higher. For treatment plants that did not return questionnaires, estimates were based on average return flows for plants serving similar populations.

\section{TRENDS IN WATER USE, 1950-85}

Nevada water-use estimates at 5-year intervals, from 1950 to 1985 , are listed in table 34 . This information is from eight U.S. Geological Survey reports on estimated use of water in the United States (MacKichan, 1951, 1957; MacKichan and Kammerer, 1961; Murray, 1968; Murray and Reeves, 1972, 1977; Solley and others, 1983, 1988). For purposes of this report, water-use estimates for some categories in the most recent report (Solley and others, 1988) have been combined to correspond to categories used in previous water-use reports. These combinations are livestock and self-supplied domestic withdrawals to correspond with rural withdrawals, and self-supplied industrial, commercial, and mining withdrawals to correspond with self-supplied industrial withdrawals.

In general, offstream water use in Nevada has increased during every 5-year interval (fig. 25). Since water-use estimates began in 1950, irrigation has been the largest offstream use. Estimates of surface-water withdrawal for irrigation have remained constant at 2,600 Mgal/d from 1970 to 1985 (fig. 26); however, ground-water withdrawals for irrigation have almost doubled, from $380 \mathrm{Mgal} / \mathrm{d}$ in 1970 (Murray and Reeves, 1972, p. 22) to $750 \mathrm{Mgal} / \mathrm{d}$ in 1985 (Solley and others, 1988 , p. 25). Public supply is the offstream category with the largest increase (620 percent) from 1950 to 1985 (fig. 26). Population increased 600 percent during this same period. Self-supplied domestic use has increased at a slower rate than public supply use from 1960 (the first year that population served by public water-supply companies was reported) to 1985 . In 1960, 20 percent of Nevada's population used selfsupplied domestic water (MacKichan and Kammerer, 1961, p. 13 and 24), and by 1985 this had decreased to 9 percent of the population (Solley and others, 1988, p. 17 and 59).

The large fluctuations in instream water use reported in the last 35 years primarily were due to variations in the percentage of releases from Hoover Dam that were reported by Nevada and Arizona.

\section{SUMMARY}

Water withdrawals in Nevada during 1985 were estimated to average $3,700 \mathrm{Mgal} / \mathrm{d}$ of freshwater and saline water for offstream uses. Offstream water-use categories are classified in this report as public supply, domestic, commercial, irrigation, nonirrigation agriculture, industrial, mining, and thermoelectric-power generation. During 1985, estimated surface-water withdrawals were $2,800 \mathrm{Mgal} / \mathrm{d}$ and estimated groundwater withdrawals were $920 \mathrm{Mgal} / \mathrm{d}$. Saline-water withdrawals during 1985 were $8.4 \mathrm{Mgal} / \mathrm{d}$ from ground water. Reclaimed wastewater averaged about $11 \mathrm{Mgal} / \mathrm{d}$ during 1985.

Public-supply facilities in Nevada withdrew approximately $290 \mathrm{Mgal} / \mathrm{d}$ in 1985 , which is nearly 8 percent of all offstream water withdrawals in the State. Of the total public-supply withdrawals, 67 percent were surface water and 33 percent were ground water. Public-supply facilities delivered approximately $190 \mathrm{Mgal} / \mathrm{d}$ to domestic users, $54 \mathrm{Mgal} / \mathrm{d}$ to commercial users, and $8.8 \mathrm{Mgal} / \mathrm{d}$ to industrial and thermoelectric users; $36 \mathrm{Mgal} / \mathrm{d}$ was either for public use or lost from the system.

Combined self-supplied withdrawals and publicsupplied deliveries for domestic use was $200 \mathrm{Mgal} / \mathrm{d}$ in 1985. Public-supplied water is the dominant means for furnishing water to the State's residents. In 1985 , more than 90 percent of domestic water was supplied by public-supply companies. Self-supplied withdrawals were $12 \mathrm{Mgal} / \mathrm{d}$ from ground water and 0.6 $\mathrm{Mgal} / \mathrm{d}$ from surface water. The largest self-supplied domestic withdrawal was in the Las Vegas Valley. 

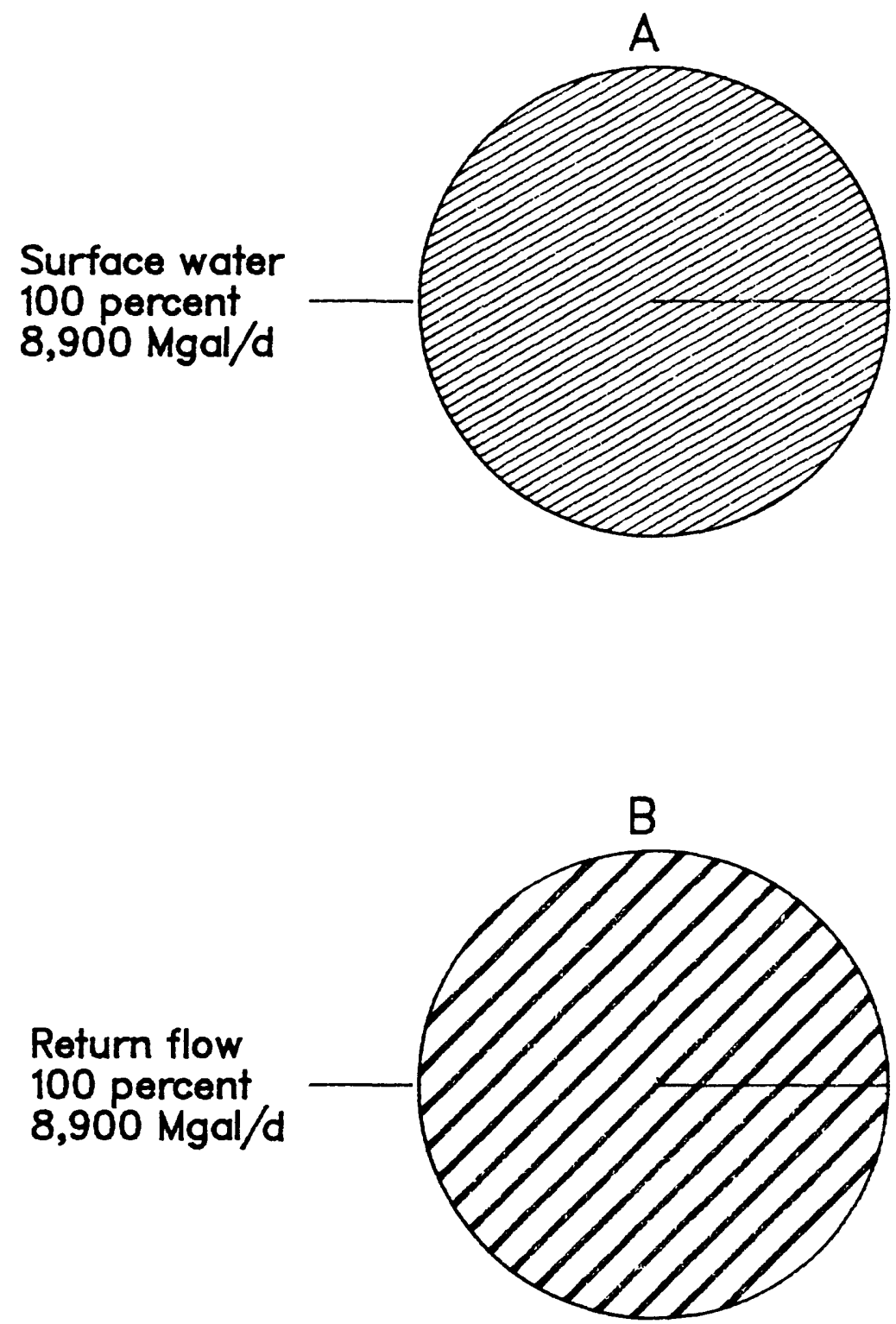

Figure 22. Hydroelectric power water use, 1985. A. Use, by source.

B. Disposition, by type. Abbreviation: Mgal/d, million gallons per day. 


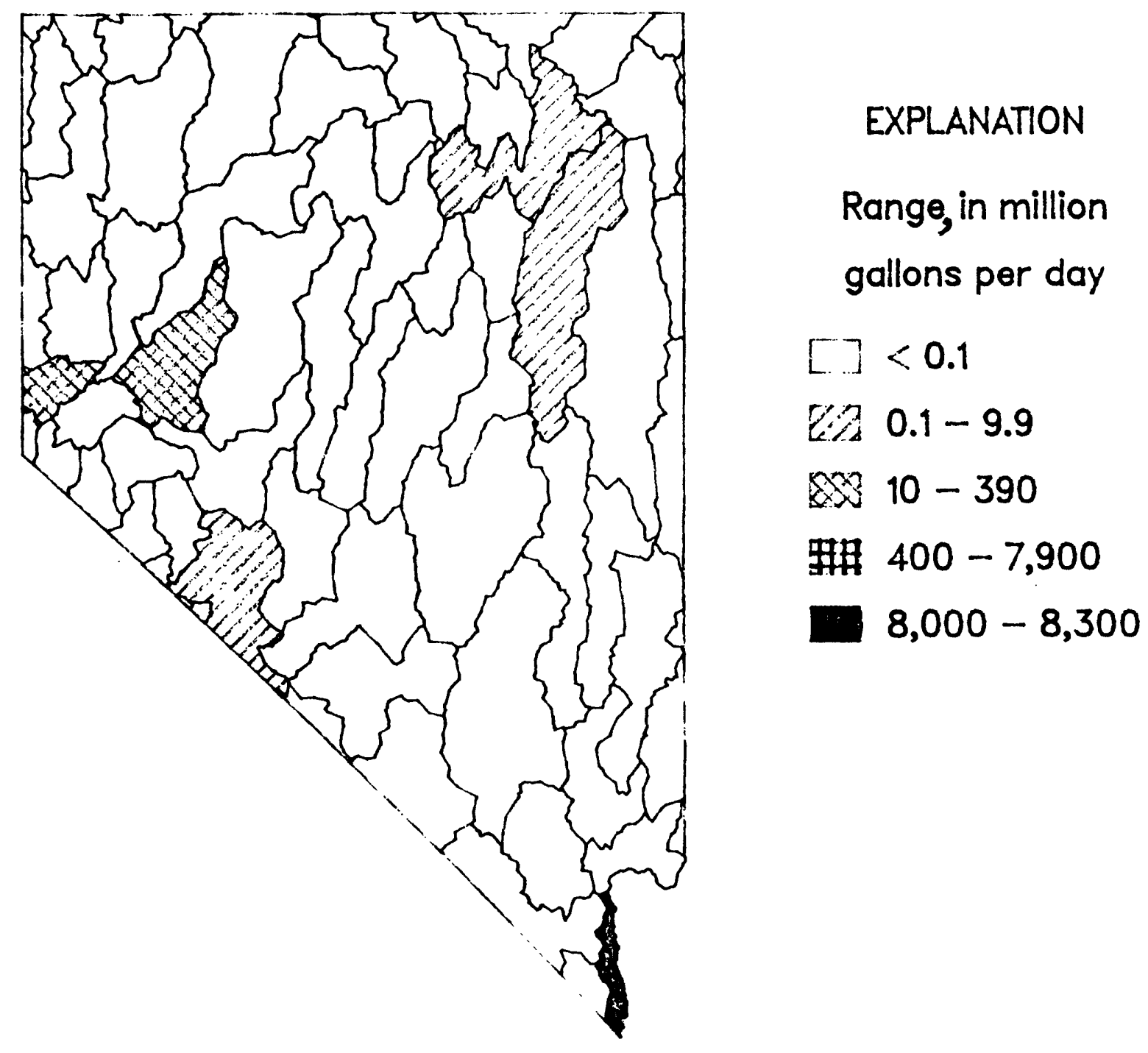

Figure 23. Hydroelectric power water use, by hydrologic cataloging unit, 1985. 


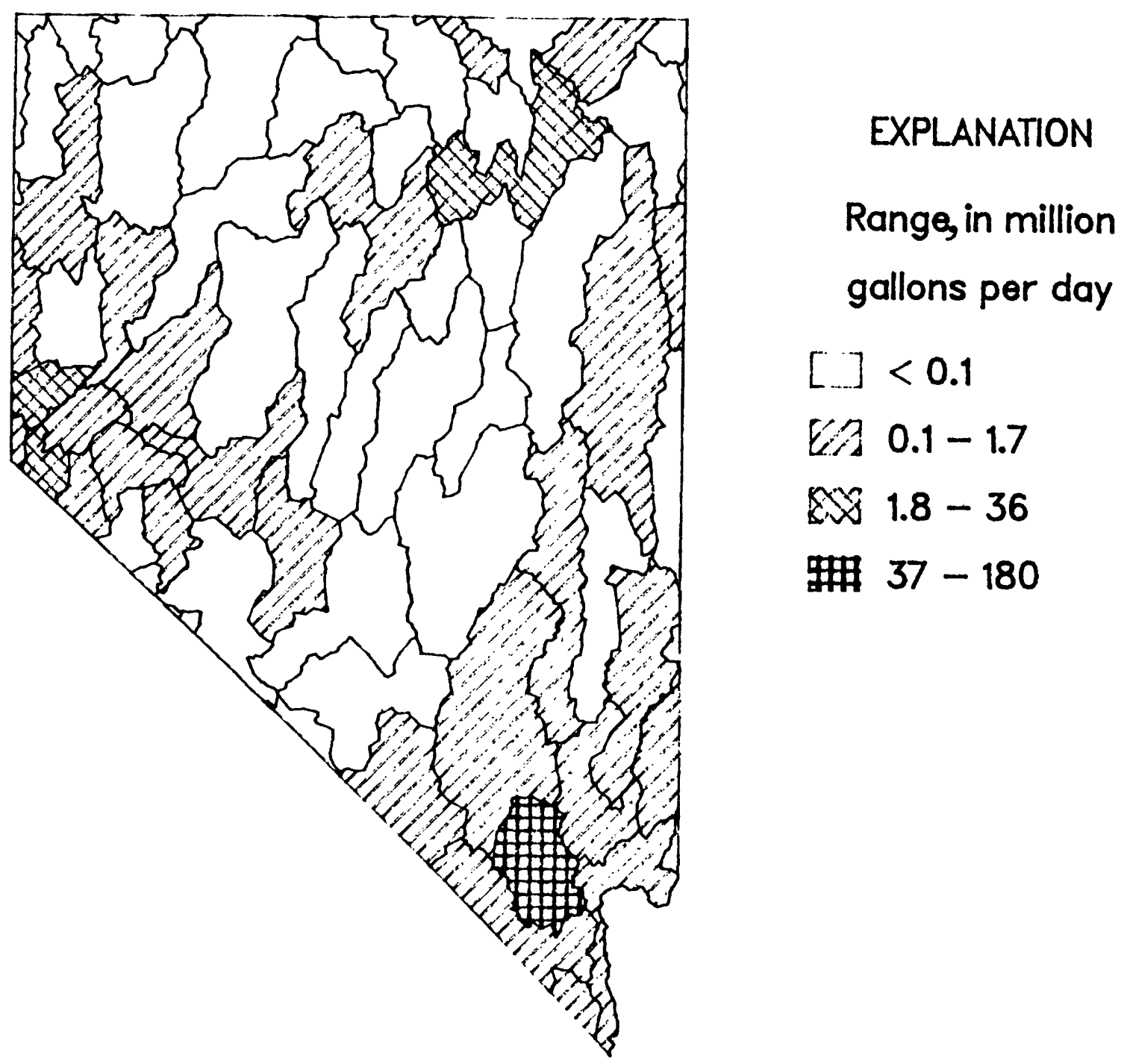

Figure 24. Water releases from public wastewater treatment facilities, by hydrologic cataloging unit, 1985. 


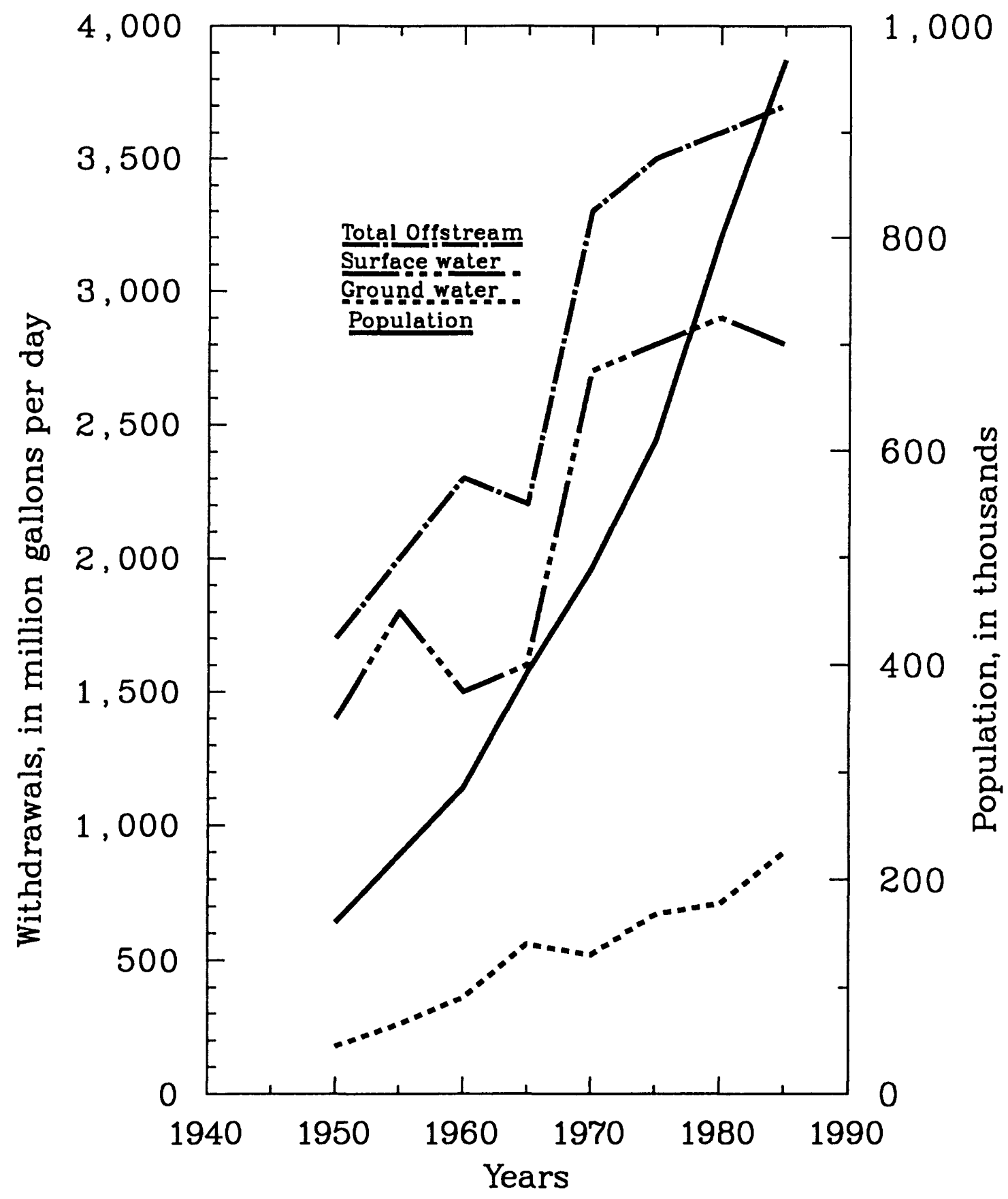

Figure 25. Trends in offstream water withdrawals and population, 1950-85. 


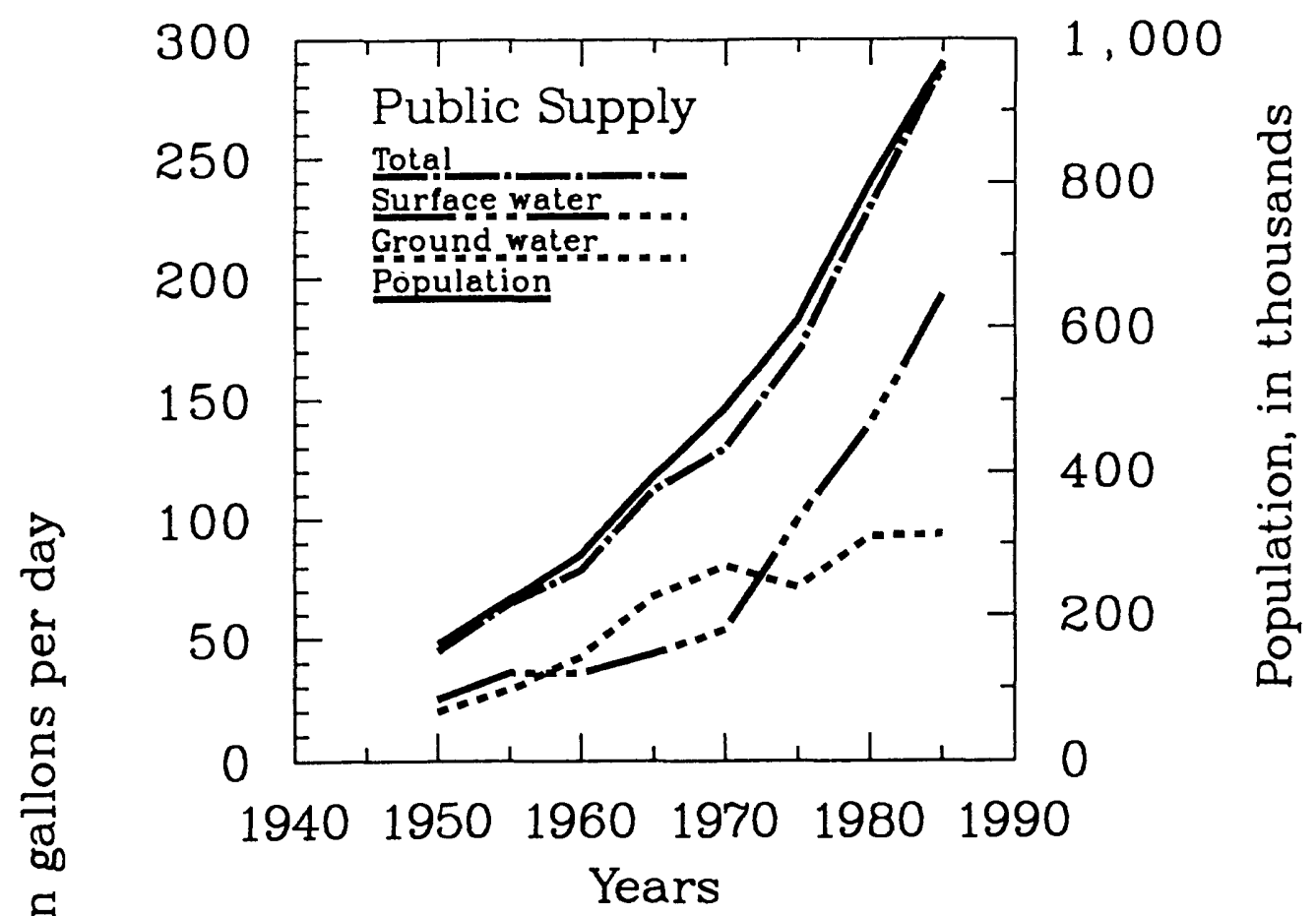

冚

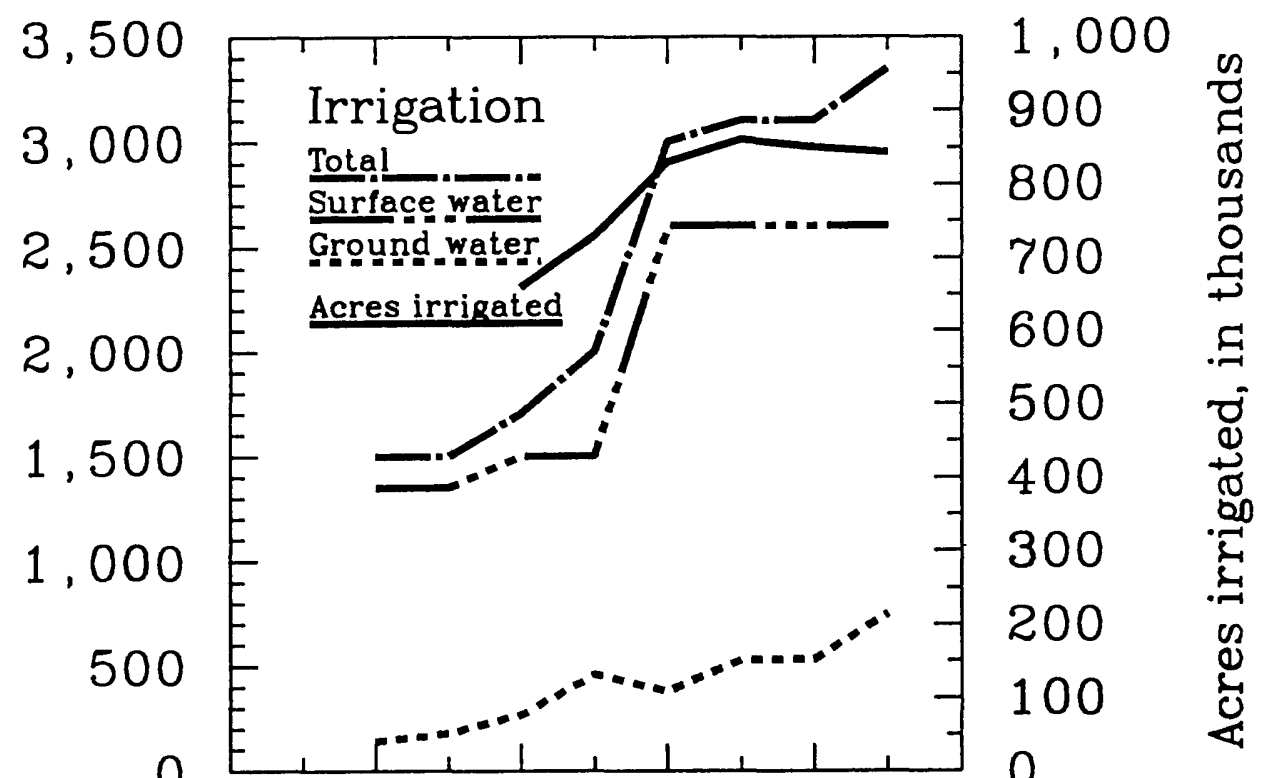

194019501960197019801990

Years

Figure 26. Trends in water withdrawals for public supply and irrigation use, 1950-85. 
More than $61 \mathrm{Mgal} / \mathrm{d}$ of water was used for commercial purposes. Public-water suppliers delivered about $54 \mathrm{Mgal} / \mathrm{d}$, or about 88 percent. The remaining 12 percent $(7.4 \mathrm{Mgal} / \mathrm{d})$ was self supplied. Ground water furnished over 95 percent ( $7 \mathrm{Mgal} / \mathrm{d}$ ) of selfsupplied commercial withdrawals. Las Vegas Valley led the State in commercial water use at a rate of $42 \mathrm{Mgal} / \mathrm{d}$.

Irrigation is the largest offstream water use category in Nevada. In 1985 , about $3,300 \mathrm{Mgal} / \mathrm{d}$ was withdrawn for irrigation, which is nearly 90 percent of all offstream withdrawals. Surface water accounts for more than three-fourths of this amount $(2,600 \mathrm{Mgal} / \mathrm{d})$. Surface-water withdrawals for irrigation are greatest along parts of the Humboldt River in north-central Nevada and the Carson River in west-central Nevada. Although ground water supplies less than one-fourth the irrigation water used in the State, its use is widely distributed. Flood irrigation was used on more than 80 percent of the 850,000 acres irrigated in the State in 1985. All crops grown in Nevada are irrigated.

Nonirrigation agriculture water use, which includes water for livestock watering, feed lots, dairy operations, and fisheries, was $26 \mathrm{Mgal} / \mathrm{d}$ in 1985 . This use accounts for 0.7 percent of the total offstream water withdrawals in Nevada. Surface water was the source for 77 percent $(20 \mathrm{Mgal} / \mathrm{d})$ of these withdrawals. The 12 fishery operations in the State withdrew $14 \mathrm{Mgal} / \mathrm{d}$, of which more than 90 percent was surface water. Estimated withdrawals for livestock watering, feed lots, and dairy operations were $12 \mathrm{Mgal} / \mathrm{d}$. Cattle are the principal livestock raised in Nevada.

Water use in 1985 for industrial purposes was $16 \mathrm{Mgal} / \mathrm{d}$. Self-supplied industrial withdrawals furnished $10 \mathrm{Mgal} / \mathrm{d}$ and public-supply systems delivered $6.3 \mathrm{Mgal} / \mathrm{d}$. About 76 percent $(7.8 \mathrm{Mgal} / \mathrm{d})$ of the selfsupplied withdrawals came from surface-water sources. Statewide, industrial use of water (including public-supply deliveries) is the smallest use of all categories, less than half of 1 percent of the total offstream withdrawals. Only 6 of the 72 hydrologic cataloging units in Nevada had self-supplied withdrawals for industrial use greater than the minimum reporting level (0.1 Mgal/d).

Water withdrawal for mining during 1985 was $30 \mathrm{Mgal} / \mathrm{d}$; all water was self supplied. Approximately 91 percent $(27 \mathrm{Mgal} / \mathrm{d}$ ) of the water was from groundwater sources. Mining was the only category to use saline water, $8.4 \mathrm{Mgal} / \mathrm{d}$ in 1985 . In Nevada, the primary mining uses of water are for mineral extraction and concentration.

In 1985, withdrawals and deliveries for thermoelectric power generation were $24 \mathrm{Mgal} / \mathrm{d}$, and power production was $12,000 \mathrm{GWh}$. Self-supplied ground water was the largest source of water for power generation, furnishing $16 \mathrm{Mgal} / \mathrm{d}$, followed by self-supplied surface water (7.5 Mgal/d), and public-supplied water (2.5 Mgal/d). Of the 11 thermoelectric power plants operating in 1985, 7 were fossil-fuel powered, and 4 geothermal powered. No nuclear-powered thermoelectric plants exist in Nevada.

Freshwater consumptive use was estimated to be $1,900 \mathrm{Mgal} / \mathrm{d}$ during 1985 . Use by irrigation, 1,700 $\mathrm{Mgal} / \mathrm{d}$, accounted for about 90 percent of the consumptive use in 1985.

The only instream water use estimated for this report was hydroelectric-power generation. Ten hydroelectric-power plants used $8,900 \mathrm{Mgal} / \mathrm{d}$ of surface water to produce 4,350 GWh of power in 1985 . The Nevada part of Hoover Dam water use, 8,300 $\mathrm{Mgal} / \mathrm{d}$, accounts for 93 percent of instream use of water in Nevada.

In 1985,83 public wastewater-treatment facilities returned $130 \mathrm{Mgal} / \mathrm{d}$ of treated effluent. In addition, 82 other facilities had discharge permits in 1985 , but the percentage that had treatment facilities is unknown. The largest wastewater-treatment releases were in Las Vegas Valley, where the largest concentration of people live.

Estimates of water use in Nevada have been made at 5-year intervals from 1950 to 1985 . In general, offstream water use in Nevada has increased during every 5 -year interval. Since water-use estimates began in 1950 , irrigation has been the largest offstream use. Surface-water withdrawals for irrigation have remained constant from 1970 to 1985 , and groundwater withdrawals have almost doubled. Public supply is the offstream category with the largest increase (620 percent) from 1950 to 1985 . Population increased 600 percent during this same period. 


\section{GLOSSARY}

Water-use terms, defined according to their meaning in this report, are listed below. Water-use terminology is continuing to expand. The term "water use," as initially used in 1950 in the U.S. Geological Survey's water-use circulars, meant withdrawals of water; in the report for 1960, the term was redefined to include consumptive use of water as well as withdrawals. With the beginning of the Survey's National Water-Use Information Program in 1978, the term was again redefined to include return flow and offstream and instream uses. In 1985 , the term was redefined to include withdrawals plus deliveries.

Acre-foot (acre-ft)-The volume of water required to cover 1 acre of land (43,560 square feet) to a depth of 1 foot.

Commercial water use-Water used by casinos, motels, restaurants, office buildings, commercial facilities, and institutions, both civilian and military. The water may be obtained from a public supply or may be self supplied. See Public supply and Self-supplied water.

Consumptive use-Water that is no longer available because it has been evaporated, transpired, incorporated into products or crops, consumed by man or livestock, or otherwise removed from the water environment. Also referred to as water consumption.

Conveyance loss-Water that is lost in transit by leakage or by evaporation from pipes, canals, conduits and ditches. Generally, the water is not available for further use; however, leakage from an irrigation ditch, for example, may percolate to a ground-water source and be available for use.

Cooling Water-Water used for cooling purposes, such as cooling of condensers and nuclear reactors.

Delivery/release-The amount of water delivered to the point of use and the amount released after use; the difference between these amounts is usually the same as the consumptive use. See Consumptive use.

Domestic water use-Water used for household purposes, such as drinking, food preparation, bathing, washing clothes and dishes, flushing toilets, and watering lawns and gardens. The water may be obtained from a public supply or may be self supplied. See Public supply and Self-supplied water.

Freshwater-Water that contains less than 1,000 milligrams per liter (mg/L) of dissolved solids; generally, more than $500 \mathrm{mg} / \mathrm{L}$ of dissolved solids is undesirable for drinking and many industrial uses.

Hydroelectric-power generation-Use of water in the generation of electricity at plants where turbine generators are driven by falling water; an instream use.
Industrial water use - Water used for industrial purposes such as fabrication, processing, washing, cooling; includes such industries as steel, food and kindred products, printing, and construction. The water may be obtained from a public supply or may be self supplied. See Public supply and Self-supplied water.

Instream use-Water use taking place within the stream channel for purposes such as hydroelectric-power generation, navigation, water-quality improvement, fish propagation, and recreation.

Irrigation district-A cooperative, self-governing public cor, oration set up as a subdivision of the State government, with definite geographic boundaries, organized and having taxing power to obtain and distribute water for irrigation of lands within the district; created under the authority of a State legislature with the consent of a designated fraction of the landowners or citizens.

Livestock water use-Water for stock watering, feed lots, dairy operations, and other farm needs. In this report, livestock includes cattle, sheep, goats, swine, poultry, and horses.

Mining water use - Water used for the extraction of naturally occurring minerals. Also includes well operation, milling (crushing, screening, washing, and flotation), and other preparations customarily done at the mine site or as part of a mining activity.

Nonirrigation agriculture water use-Water used for livestock and fisheries. See Livestock water use.

Offstream use - Water withdrawn or diverted from a ground- or surface-water source for public-water supply, industry, irrigation, nonirrigation agriculture, thermoelectric power generation, and other uses.

Public supply - Water withdrawn by public and private water suppliers and delivered to at least 25 people or through at least 15 connections per system. Public suppliers provide water for various uses, such as domestic, commercial, thermoelectric power, industrial, and public water use. See Commercial water use, Domestic water use, Thermoelectric power, Industrial water use, and Public water use.

Public water use-Water supplied from a public-water supply and used for firefighting, street washing, and other municipal uses.

Reclaimed wastewater-Wastewater treatment-plant effluent that is reused. See Wastewater treatment.

Return flow-Water that reaches a ground- or surface-water source after release from the point of use and, thus, becomes available for further use.

Saline water-Water that contains more than 1,000 milligrams per liter of dissolved solids.

Self-supplied water-Water withdrawn from a surface- or ground-water source by a user rather than being obtained from a public-supply facility. 
Thermoelectric power-Electrical power generated using fossil-fuel (coal, oil, or natural gas), geothermal, or nuclear energy. No nuclear thermoelectric power plants exist in Nevada.

Wastewater treatment-Processing of wastewater for the removal or reduction of solids or other constituents so that it can be returned to the hydrologic system.

Water withdrawal-Water removed from the ground or diverted from a surface-water source for use. Withdrawals minus conveyance losses equals use. See Offstream use and Self-supplied water.

\section{REFERENCES CITED}

Baker, Arthur, III, Archbold, N.L., and Stoll, W.J., 1973, Water for Nevada_-Forecasts for the future-Mining: Nevada Division of Water Resources, Water Planning Report 4, $223 \mathrm{p}$.

Berggren, Gregg, and Harrill, J.R., 1986, Vegetation, South Lake Tahoe quadrangle [Nevada and California]: Nevada Bureau of Mines and Geology Urban Maps Series, South Lake Tahoe Folio, Map 2Ae, scale $1: 24,000$.

Carr, J.E., Chase, E.B., Paulson, R.W., and Moody, D.W., comps., 1990, National water summary 1987-Hydrologic events and water supply and use: U.S. Geological Survey Water-Supply Paper 2350, $553 \mathrm{p}$.

Harrill, J.R., and Worts, G.F., Jr., 1968, Estimated water use in Nevada, 1950-65: Nevada Division of Water Resources, Information Report 7, $37 \mathrm{p}$.

Holmes, G.H., Jr., 1966, Water requirements and uses in Nevada mineral industries: U.S. Bureau of Mines Information Circular 8288, $66 \mathrm{p}$.

MacKichan, K.A., 1951, Estimated water use in the United States, 1950: U.S. Geological Survey Circular 115, $13 \mathrm{p}$.

1957, Estimated water use in the United States, 1955: U.S. Geological Survey Circular 398, 18 p.

MacKichan, K.A., and Kammerer, J.C., 1961, Estimated use of water in the United States, 1960: U.S. Geological Survey Circular 456, $26 \mathrm{p}$.

Murray, C.R., 1968, Estimated use of water in the United States, 1965: U.S. Geological Survey Circular 556, $53 \mathrm{p}$.

Murray, C.R., and Reeves, E.B., 1972, Estimated use of water in the United States in 1970: U.S. Geological Survey Circular 676, $37 \mathrm{p}$.

1977, Estimated use of water in the United States in 1975: U.S. Geological Survey Circular 765, 37 p.

Nevada Commission on Economic Development, 1985, Nevada industrial directory 1985-1986: Carson City, $102 \mathrm{p}$.
Nevada Crop and Livestock Reporting Service, 1985, 1984 Nevada agricultural statistics: Reno, Nevada Department of Agriculture, $36 \mathrm{p}$.

Nevada Department of Agriculture, 1986, 1985-86 Nevada agricultural statistics: Reno, 39 p.

Nevada Division of Mine Inspection, 1986, Directory of Nevada mine operations active during calendar year 1985: Nevada Department of Industrial Relations, $79 \mathrm{p}$.

Nevada Division of Water Planning, 1979, Land application of wastewater in Nevada: Nevada Department of Conservation and Natural Resources, Information Series, Water Planning Report 2, $267 \mathrm{p}$.

Resource Concepts, Inc., 1984, Public and private water sysrems in Nevada: Carson City, 43 p.

Rush, F.E., 1968, Index of hydrographic areas in Nevada: Nevada Division of Water Resources, Water Resources, Information Report 6, 38 p.

Seaber, P.R., Kapinos, F.P., and Knapp, G.L., 1984, State hydrologic unit maps: U.S. Geological Survey OpenFile Report 84-708, 198 p.

Smales, T.J., and Harrill, J.R., 1971, Estimated water use in Nevada: Nevada Division of Water Resources, Water for Nevada Report 2, $32 \mathrm{p}$.

Solley, W.B., Chase, E.B., and Mann, W.B., IV, 1983, Estimated use of water in the United States in 1980:

U.S. Geological Survey Circular 1001, 56 p.

Solley, W.B., Merk, C.F., and Pierce, R.R., 1988, Estimated use of water in the United States in 1985: U.S. Geological Survey Circular 1004, $82 \mathrm{p}$.

U.S. Bureau of Land Management, 1986, Nevada progress report-1985: Reno, Report BLMNVGI86061120, unpaginated.

U.S. Bureau of the Census, 1983, Detailed housing characteristics, Nevada: Washington, D.C.. U.S. Government Printing Office, v. 1, chap. B, $70 \mathrm{p}$.

-1984, 1982 Census of agriculture-Nevada, state and county data: Washington, D.C., U.S. Government Printing Office, v. 1, pt. 28, 196 p.

1985a, 1983 County business patterns, NevadaEmployment and payrolls, number and employment size of establishments by detailed industry: Washington, D.C., U.S. Government Printing Office, 35 p. $-1985 \mathrm{~b}, 1982$ Census of mineral industries-Water use in mineral industries: Washington, D.C., U.S. Government Printing Office, 31 p., plus appendices.

1986a, 1982 Census of manufactures-Water use in manufacturing: Washington, D.C., U.S. Government Printing Office, $72 \mathrm{p}$., plus appendices.

1986b, 1984 Farm and ranch irrigation survey:

Washington, D.C., U.S. Government Printing Office, $85 \mathrm{p}$.

U.S. Geological Survey, 1974, Hydrologic unit map of Nevada: U.S. Geological Survey Hydrologic Unit Map, 1 sheet, scale 1:500,000. 
1979, Land use and land cover, 1973, Reno, Nevada; California: U.S. Geological Survey Land Use Series Map L-64, scale 1:250,000.

1980a, Land use and land cover, 1973-76, Kingman, Arizona-Nevada-California: U.S. Geological Survey Open-File Report 80-627-1, scale 1:250,000.

1980b, Land use and land cover, 1973-77, Las Vegas, Nevada-Arizona-California: U.S. Geological Survey Open-File Report 80-272-1, scale 1:250,000.

1980c, Land use and land cover, 1973-79, Walker Lake, Nevada-California: U.S. Geological Survey Open-File Report 80-151-1, scale 1:250,000.

1980d, Land use and land cover, 1975-79, Goldfield, Nevada-California: U.S. Geological Survey OpenFile Report 80-2027-1, scale 1:250,000.

1980e, Land use and land cover, 1976, Death Valley, California-Nevada: U.S. Geological Survey Open-File Report 80-859-1, scale 1:250,000.

1983a, Land use and land cover, 1980, Elko, Nevada-Utah: U.S. Geological Survey Open-File Report 83-109-1, scale 1:250,000.

1983b, Land use and land cover, 1980, Ely, NevadaUtah: U.S. Geological Survey Open-File Report 83-569-1, scale 1:250,000.

1983c, Land use and land cover, 1980, Lovelock, Nevada-California: U.S. Geological Survey Open-File Report 83-111-1, scale 1:250,000. 1983d, Land use and land cover, 1980, Lund. Nevada-Utah: U.S. Geological Survey Open-File Report 83-564-1, scale 1:250,000.

1983e, Land use and land cover, 1980, Vya, NevadaOregon-California: U.S. Geological Survey Open-File Report 83-110-1, scale 1:250,000.

1983f, Land use and land cover, 1980, Wells, Nevada-Utah-Idaho: U.S. Geological Survey OpenFile Report 83-108-1, scale 1:250,000.

1984a, Land use and land cover, 1980, Tonopah, Nevada: U.S. Geological Survey Open-File Report 84-046-1, scale 1:250,000.

1984b, Land use and land cover, 1980,83, Winnemucca, Nevada: U.S. Geological Survey Open-File Report 84-044-1, scale 1:250,000.

1984c, Land use and land cover, 1983, Caliente, Nevada-Utah: U.S. Geological Survey Open-File Report 84-0531-1, scale 1:250,000.

1984d, Land use and land cover, 1983, McDermitt, Nevada-Oregon-Idaho: U.S. Geological Survey Open-File Report 84-047-1, scale 1:250,000.

1984e, Land use and land cover, 1983, Millett. Nevada: U.S. Geological Survey Open-File Report 84-045-1, scale 1:250,000.

U.S. Soil Conservation Service, 1985, Nevada irrigation guide: Reno, Report NV210-VI-NVIG, unpaginated. 
Tables

+3 3

-pege 45 follows) 
Table 1. National hydrologic cataloging units and corresponding Nevada hydrographic areas, grouped by Nevada regions and basins

[Data sources: Hydrologic units--Seaber and others (1984); hydrographic areas--Rush (1968)]

\begin{tabular}{|c|c|c|c|c|}
\hline \multirow{2}{*}{$\begin{array}{c}\text { Map } \\
\text { number } \\
\text { (fig. 1) }\end{array}$} & \multicolumn{2}{|c|}{ Hydrologic cataloging unit } & \multicolumn{2}{|r|}{ Nevada hydrographic area } \\
\hline & Number & Name & Number & Name \\
\hline \multicolumn{5}{|c|}{ Colorado River Basin } \\
\hline 1 & 15010005 & Lake Mead & $\begin{array}{l}215 \\
223\end{array}$ & $\begin{array}{l}\text { Black Mountain Area } \\
\text { Jold Butte Area }\end{array}$ \\
\hline 2 & 15010006 & Grand Wash & 224 & Greasewood Basin \\
\hline 3 & 15010010 & Lower Virgin & $\begin{array}{l}221 \\
222\end{array}$ & $\begin{array}{l}\text { Tule Desert } \\
\text { Virgin River Valley }\end{array}$ \\
\hline 4 & 15010011 & White & $\begin{array}{l}207 \\
208 \\
209\end{array}$ & $\begin{array}{l}\text { White River Valley } \\
\text { Pahroc Valley } \\
\text { Pahranagat Valley }\end{array}$ \\
\hline 5 & 15010012 & Muddy & $\begin{array}{l}206 \\
210 \\
216 \\
217 \\
218 \\
219 \\
220\end{array}$ & $\begin{array}{l}\text { Kane Springs Valley } \\
\text { Coyote Spring Valley } \\
\text { Garnet Valley (Dry Lake Valley) } \\
\text { Hidden Valley (North) } \\
\text { California Wash } \\
\text { Muddy River Springs Area (Upper Moapa Valley) } \\
\text { Lower Moapa Valley }\end{array}$ \\
\hline 6 & 15010013 & Meadow Valley Wash & $\begin{array}{l}198 \\
199 \\
200 \\
201 \\
202 \\
203 \\
204 \\
205\end{array}$ & $\begin{array}{l}\text { Dry Valley } \\
\text { Rose Valley } \\
\text { Eagle Valley } \\
\text { Spring Valley } \\
\text { Patterson Valley } \\
\text { Panaca Valley } \\
\text { Clover Valley } \\
\text { Lower Meadow Valley Wash }\end{array}$ \\
\hline 7 & 15010015 & Las Vegas Wash & $\begin{array}{l}211 \\
212\end{array}$ & $\begin{array}{l}\text { Three Lakes Valley (Southern Part) } \\
\text { Las Vegas Valley }\end{array}$ \\
\hline 8 & 15030101 & Havasu-Mohave Lakes & 213 & Colorado River Valley \\
\hline 9 & 15030102 & Piute Wash & 214 & Piute Valley \\
\hline \multicolumn{5}{|c|}{ Great Salt Lake Basin } \\
\hline 10 & 16020301 & Hamlin-Snake Valleys & $\begin{array}{l}194 \\
195 \\
196\end{array}$ & $\begin{array}{l}\text { Pleasant Valley } \\
\text { Snake Valley } \\
\text { Hamlin Valley }\end{array}$ \\
\hline 11 & 16020306 & $\begin{array}{l}\text { Southern Great Salt Lake } \\
\text { Desert }\end{array}$ & $\begin{array}{l}192^{\mathrm{a}} \\
193\end{array}$ & $\begin{array}{l}\text { Great Salt Lake Desert } \\
\text { Deep Creek Valley }\end{array}$ \\
\hline 12 & 16020307 & Pilot-Thousand Springs & $\begin{array}{l}189 \\
189 \mathrm{~A} \\
189 \mathrm{~B} \\
189 \mathrm{C} \\
189 \mathrm{D} \\
191\end{array}$ & $\begin{array}{l}\text { Thousand Springs Valley } \\
\text { Herrell Siding-Brush Creek Area } \\
\text { Toano-Rock Spring Area } \\
\text { Rocky Butte Area } \\
\text { Montello-Crittenden Creek Area } \\
\text { Pilot Creek Valley }\end{array}$ \\
\hline 13 & 16020308 & $\begin{array}{l}\text { Northern Great Salt Lake } \\
\text { Desert }\end{array}$ & $\begin{array}{l}190 \\
192^{b}\end{array}$ & $\begin{array}{l}\text { Grouse Creek Valley } \\
\text { Great Salt Lake Desert }\end{array}$ \\
\hline
\end{tabular}


Table 1. National hydrologic cataloging units and corresponding Nevada hydrographic areas, grouped by Nevada regions and basins-Continued

\begin{tabular}{|c|c|c|c|c|}
\hline \multirow{2}{*}{$\begin{array}{l}\text { Map } \\
\text { number } \\
\text { (fig. 1) }\end{array}$} & \multicolumn{2}{|c|}{ Hydrologlc cataloging unlt } & \multicolumn{2}{|r|}{ Nevada hydrographlc area } \\
\hline & Number & Name & Number & Name \\
\hline \multicolumn{5}{|c|}{ Escalante Desert } \\
\hline 14 & 16030006 & Escalante Desert & 197 & Escalante Desert \\
\hline \multicolumn{5}{|c|}{ Humboldt River Basin } \\
\hline 15 & 16040101 & Upper Humboldt & $\begin{array}{l}42 \\
43 \\
45 \\
49 \\
50 \\
51 \\
52\end{array}$ & $\begin{array}{l}\text { Marys River Area } \\
\text { Starr Valley Area } \\
\text { Lamoille Valley } \\
\text { Elko Segment } \\
\text { Susie Creek Area } \\
\text { Maggie Creek Area } \\
\text { Marys Creek Area }\end{array}$ \\
\hline 16 & 16040102 & North Fork Humboldt & 44 & North Fork Area \\
\hline 17 & 16040103 & South Fork Humboldt & $\begin{array}{l}46 \\
47 \\
48\end{array}$ & $\begin{array}{l}\text { South Fork Area } \\
\text { Huntington Valley } \\
\text { Dixie Creek-Tenmile Creek Area }\end{array}$ \\
\hline 18 & 16040104 & Pine & 53 & Pine Valley \\
\hline 19 & 16040105 & Middle Humboldt & $\begin{array}{l}54 \\
55 \\
59^{\mathrm{a}} \\
60 \\
61 \\
64 \\
65 \\
66\end{array}$ & $\begin{array}{l}\text { Crescent Valley } \\
\text { Carico Lake Valley } \\
\text { Lower Reese River Valley } \\
\text { Whirlwind Valley } \\
\text { Boulder Flat } \\
\text { Clovers Area } \\
\text { Pumpernickel Valley } \\
\text { Kelley Creek Area }\end{array}$ \\
\hline 20 & 16040106 & Rock & $\begin{array}{l}62 \\
63\end{array}$ & $\begin{array}{l}\text { Rock Creek Valley } \\
\text { Willow Creek Valley }\end{array}$ \\
\hline 21 & 16040107 & Reese & $\begin{array}{l}56 \\
57 \\
58 \\
59^{\mathrm{a}}\end{array}$ & $\begin{array}{l}\text { Upper Reese River Valley } \\
\text { Antelope Valley } \\
\text { Middle Reese River Valley } \\
\text { Lower Reese River Valley }\end{array}$ \\
\hline 22 & 16040108 & Lower Humboldt & $\begin{array}{l}70 \\
71 \\
72 \\
73 \\
73 \mathrm{~A} \\
74\end{array}$ & $\begin{array}{l}\text { Winnemucca Segment } \\
\text { Grass Valley } \\
\text { Imlay Area } \\
\text { Lovelock Valley } \\
\text { Oreana Subarea } \\
\text { White Plains }\end{array}$ \\
\hline 23 & 16040109 & Little Humboldt & $\begin{array}{l}67 \\
68 \\
69\end{array}$ & $\begin{array}{l}\text { Little Humboldt Valley } \\
\text { Hardscrabble Area } \\
\text { Paradise Valley }\end{array}$ \\
\hline
\end{tabular}


Table 1. National hydrologic cataloging units and corresponding Nevada hydrographic areas, grouped by Nevada regions and basins-Continued

\begin{tabular}{|c|c|c|c|c|}
\hline \multirow{2}{*}{$\begin{array}{c}\text { Map } \\
\text { number } \\
\text { (fig. 1) }\end{array}$} & \multicolumn{2}{|c|}{ Hydrologic cataloging unit } & \multicolumn{2}{|r|}{ Nevada hydrographic ares } \\
\hline & Number & Name & Number & Name \\
\hline \multicolumn{5}{|c|}{ Black Rock Desert Region } \\
\hline 24 & 16040201 & Upper Quinn & $\begin{array}{l}30 \\
30 \mathrm{~A} \\
30 \mathrm{~B} \\
31 \\
32 \\
33 \\
33 \mathrm{~A} \\
33 \mathrm{~B}\end{array}$ & $\begin{array}{l}\text { Kings River Valley } \\
\text { Rio King Subarea } \\
\text { Sod House Subarea } \\
\text { Desert Valley } \\
\text { Silver State Valley } \\
\text { Quinn River Valley } \\
\text { Orovada Subarea } \\
\text { McDermitt Subarea }\end{array}$ \\
\hline 25 & 16040202 & Lower Quinn & $\begin{array}{l}23 \\
26 \\
27 \\
28 \\
29\end{array}$ & $\begin{array}{l}\text { Granite Basin } \\
\text { Mud Meadow } \\
\text { Summit Lake Valley } \\
\text { Black Rock Desert } \\
\text { Pine Forest Valley }\end{array}$ \\
\hline 26 & 16040203 & Smoke Creek Desert & $\begin{array}{l}19 \\
20 \\
21 \\
22 \\
24 \\
25\end{array}$ & $\begin{array}{l}\text { Dry Valley } \\
\text { Sano Valley } \\
\text { Smoke Creek Desert } \\
\text { San Emidio Desert } \\
\text { Hualapai Flat } \\
\text { High Rock Lake Valley }\end{array}$ \\
\hline 27 & 18080002 & Madeline Plains & $\begin{array}{l}17 \\
18\end{array}$ & $\begin{array}{l}\text { Pilgrim Flat } \\
\text { Painters Flat }\end{array}$ \\
\hline
\end{tabular}

\begin{tabular}{lrlrl}
\hline & & Truckee River Basin & \\
\hline 28 & 16050101 & Lake Tahoe & 90 & Lake Tahoe Basin \\
29 & 16050102 & Truckee & 83 & Tracy Segment \\
& & 85 & Spanish Springs Valley \\
& & 86 & Sun Valley \\
& & 87 & Truckee Meadows \\
& & 88 & Pleasant Valley \\
& & 89 & Washoe Valley \\
30 & & & 91 & Truckee Canyon Segment \\
& & & 80 & Winnemucca Lake Valley \\
& & & 81 & Pyramid Lake Valley \\
& & 82 & Dodge Flat \\
& & 84 & Warm Springs Valley \\
& & & \\
\hline & & & & \\
\hline & & & 75 & Bradys Hot Springs Area \\
& & & 76 & Fernley Area \\
& & & 77 & Fireball Valley \\
& & & 78 & Granite Springs Valley \\
& & & 79 & Kumiva Valley
\end{tabular}


Table 1. National hydrologic cataloging units and corresponding Nevada hydrographic areas, grouped by Nevada regions and basins-Continued

\begin{tabular}{|c|c|c|c|c|}
\hline \multirow{2}{*}{$\begin{array}{l}\text { Map } \\
\text { number } \\
\text { (fig. 1) }\end{array}$} & \multicolumn{2}{|c|}{ Hydrologic cataloging unit } & \multicolumn{2}{|r|}{ Nevada hydrographic area } \\
\hline & Number & Name & Number & Name \\
\hline \multicolumn{5}{|c|}{ Carson River Basin } \\
\hline 32 & 16050201 & Upper Carson & $\begin{array}{l}104 \\
105\end{array}$ & $\begin{array}{l}\text { Eagle Valley } \\
\text { Carson Valley }\end{array}$ \\
\hline 33 & 16050202 & Middle Carson & $\begin{array}{l}102 \\
103\end{array}$ & $\begin{array}{l}\text { Churchill Valley } \\
\text { Dayton Valley }\end{array}$ \\
\hline 34 & 16050203 & Lower Carson & $\begin{array}{l}101 \\
101 \mathrm{~A}\end{array}$ & $\begin{array}{l}\text { Carson Desert } \\
\text { Packard Valley }\end{array}$ \\
\hline \multicolumn{5}{|c|}{ Walker River Basin } \\
\hline 35 & 16050301 & East Walker & 109 & East Walker Area \\
\hline 36 & 16050302 & West Walker & $\begin{array}{l}106 \\
107\end{array}$ & $\begin{array}{l}\text { Antelope Valley } \\
\text { Smith Valley }\end{array}$ \\
\hline 37 & 16050303 & Walker & $\begin{array}{l}108 \\
110 \\
110 \mathrm{~A}\end{array}$ & $\begin{array}{l}\text { Mason Valley } \\
\text { Walker Lake Valley } \\
\text { Schurz Subarea }\end{array}$ \\
\hline 38 & 16050304 & Walker Lake & $\begin{array}{l}110 \mathrm{~B} \\
110 \mathrm{C}\end{array}$ & $\begin{array}{l}\text { Lake Subarea } \\
\text { Whiskey Flat - Hawthorne Subarea }\end{array}$ \\
\hline \multicolumn{5}{|c|}{ Central Region } \\
\hline 39 & 16060001 & Dixie Valley & $\begin{array}{l}123 \\
124 \\
125 \\
126 \\
127 \\
128 \\
129 \\
130 \\
131 \\
132 \\
133\end{array}$ & $\begin{array}{l}\text { Rawhide Flats } \\
\text { Fairview Valley } \\
\text { Stingaree Valley } \\
\text { Cowkick Valley } \\
\text { Eastgate Valley Area } \\
\text { Dixie Valley } \\
\text { Buena Vista Valley } \\
\text { Pleasant Valley } \\
\text { Buffalo Valley } \\
\text { Jersey Valley } \\
\text { Edwards Creek Valley }\end{array}$ \\
\hline 40 & 16060002 & Gabbs Valley & $\begin{array}{l}122 \\
134\end{array}$ & $\begin{array}{l}\text { Gabbs Valley } \\
\text { Smith Creek Valley }\end{array}$ \\
\hline 41 & 16060003 & Southern Big Smoky Valley & $\begin{array}{l}135 \\
137 \\
137 \mathrm{~A}\end{array}$ & $\begin{array}{l}\text { Ione Valley } \\
\text { Big Smoky Valley } \\
\text { Tonopah Flat }\end{array}$ \\
\hline 42 & 16060004 & Northern Big Smoky Valley & $\begin{array}{l}137 \mathrm{~B} \\
138\end{array}$ & $\begin{array}{l}\text { Northern Part } \\
\text { Grass Valley }\end{array}$ \\
\hline 43 & 16060005 & Diamond-Monitor Valleys & $\begin{array}{l}139 \\
140 \\
140 \mathrm{~A} \\
140 \mathrm{~B} \\
151 \\
152 \\
153 \\
157\end{array}$ & $\begin{array}{l}\text { Kobeh Valley } \\
\text { Monitor Valley } \\
\text { Northern Part } \\
\text { Southern Part } \\
\text { Antelope Valley (Eureka and Nye) } \\
\text { Stevens Basin } \\
\text { Diamond Valley } \\
\text { Kawich Valley }\end{array}$ \\
\hline
\end{tabular}


Table 1. National hydrologic cataloging units and corresponding Nevada hydrographic areas, grouped by Nevada regions and basins-Continued

\begin{tabular}{|c|c|c|c|c|}
\hline \multirow{2}{*}{$\begin{array}{l}\text { Map } \\
\text { number } \\
\text { (fig. 1) }\end{array}$} & \multicolumn{2}{|c|}{ Hydrologic cataioging unit } & \multicolumn{2}{|r|}{ Nevada hydrographic area } \\
\hline & Number & Name & Number & Name \\
\hline \multicolumn{5}{|c|}{ Central Region-Continued } \\
\hline 44 & 16060006 & Little Smoky-Newark Valleys & $\begin{array}{l}154 \\
155 \\
155 \mathrm{~A} \\
155 \mathrm{~B}\end{array}$ & $\begin{array}{l}\text { Newark Valley } \\
\text { Little Smoky Valley } \\
\text { Northern Part } \\
\text { Central Part }\end{array}$ \\
\hline 45 & 16060007 & Long-Ruby Valleys & $\begin{array}{l}174 \\
175 \\
176 \\
177 \\
178 \\
178 \mathrm{~A} \\
178 \mathrm{~B} \\
188\end{array}$ & $\begin{array}{l}\text { Jakes Valley } \\
\text { Long Valley } \\
\text { Ruby Valley } \\
\text { Clover Valley } \\
\text { Butte Valley } \\
\text { Northern Part (Round Valley) } \\
\text { Southern Part } \\
\text { Independence Valley (Pequop Valley) }\end{array}$ \\
\hline 46 & 16060008 & Spring-Steptoe Valleys & $\begin{array}{l}179 \\
184 \\
185 \\
186 \\
186 \mathrm{~A} \\
186 \mathrm{~B} \\
187\end{array}$ & $\begin{array}{l}\text { Steptoe Valley } \\
\text { Spring Valley } \\
\text { Tippett Valley } \\
\text { Antelope Valley (White Pine and Elko) } \\
\text { Southern Part } \\
\text { Northern Part } \\
\text { Goshute Valley }\end{array}$ \\
\hline 47 & 16060009 & Dry Lake Valley & $\begin{array}{l}180 \\
181 \\
182 \\
183\end{array}$ & $\begin{array}{l}\text { Cave Valley } \\
\text { Dry Lake Valley } \\
\text { Delamar Valley } \\
\text { Lake Valley }\end{array}$ \\
\hline 48 & 16060010 & Fish Lake-Soda Spring Valleys & $\begin{array}{l}113 \\
114 \\
117 \\
118 \\
119 \\
120 \\
121 \\
121 \mathrm{~A} \\
121 \mathrm{~B} \\
136\end{array}$ & $\begin{array}{l}\text { Huntoon Valley } \\
\text { Teels Marsh Valley } \\
\text { Fish Lake Valley } \\
\text { Columbus Salt Marsh Valley } \\
\text { Rhodes Salt Marsh Valley } \\
\text { Garfield Flat } \\
\text { Soda Spring Valley } \\
\text { Eastern Part } \\
\text { Western Part } \\
\text { Monte Cristo Valley }\end{array}$ \\
\hline 49 & 16060011 & Ralston-Stone Cabin Valleys & $\begin{array}{l}141 \\
142 \\
143 \\
148 \\
149\end{array}$ & $\begin{array}{l}\text { Ralston Valley } \\
\text { Alkali Spring Valley (Esmeralda) } \\
\text { Clayton Valley } \\
\text { Cactus Flat } \\
\text { Stone Cabin Valley }\end{array}$ \\
\hline 50 & 16060012 & Hot Creek-Railroad Valleys & $\begin{array}{l}150 \\
155 \mathrm{C} \\
156 \\
173 \\
173 \mathrm{~A} \\
173 \mathrm{~B}\end{array}$ & $\begin{array}{l}\text { Little Fish Lake Valley } \\
\text { Little Smoky Valley, Southern part } \\
\text { Hot Creek Valley } \\
\text { Railroad Valley } \\
\text { Southern part } \\
\text { Northern Part }\end{array}$ \\
\hline
\end{tabular}


Table 1. National hydrologic cataloging units and corresponding Nevada hydrographic areas, grouped by Nevada regions and basins-Continued

\begin{tabular}{|c|c|c|c|c|}
\hline \multirow{2}{*}{$\begin{array}{c}\text { Map } \\
\text { number } \\
\text { (fig. 1) }\end{array}$} & \multicolumn{2}{|c|}{ Hydrologic cataloging unit } & \multicolumn{2}{|r|}{ Nevada hydrographic area } \\
\hline & Number & Name & Number & Name \\
\hline \multicolumn{5}{|c|}{ Central Region-continued } \\
\hline 51 & 16060013 & Cactus-Sarcobatus Flats & $\begin{array}{l}144 \\
145 \\
146 \\
147\end{array}$ & $\begin{array}{l}\text { Lida Valley } \\
\text { Stonewall Flat } \\
\text { Sarcobatus Flat } \\
\text { Gold Flat }\end{array}$ \\
\hline 52 & 16060014 & Sand Spring-Tikaboo Valleys & $\begin{array}{l}158 \\
158 \mathrm{~A} \\
158 \mathrm{~B} \\
159 \\
160 \\
161 \\
168 \\
169 \\
169 \mathrm{~A} \\
169 \mathrm{~B} \\
170 \\
171 \\
172\end{array}$ & $\begin{array}{l}\text { Emigrant Valley } \\
\text { Groom Lake Valley } \\
\text { Papoose Lake Valley } \\
\text { Yucca Flat } \\
\text { Frenchman Flat } \\
\text { Indian Springs Valley } \\
\text { Three Lakes Valley (Northern Part) } \\
\text { Tikapoo Valley } \\
\text { Northern Part } \\
\text { Southern Part } \\
\text { Penoyer Valley } \\
\text { (Sand Spring Valley) } \\
\text { Coal Valley } \\
\text { Garden Valley }\end{array}$ \\
\hline 53 & 16060015 & Ivanpah-Pahrump & $\begin{array}{l}162 \\
163 \\
164 \\
164 \mathrm{~A} \\
164 \mathrm{~B} \\
165 \\
166 \\
167\end{array}$ & $\begin{array}{l}\text { Pahrump Valley } \\
\text { Mesquite Valley } \\
\quad \text { (Sandy Valley) } \\
\text { Ivanpah Valley } \\
\text { Northern Part } \\
\text { Southern Part } \\
\text { Jean Lake Valley } \\
\text { Hidden Valley (South) } \\
\text { Eldorado Valley }\end{array}$ \\
\hline 54 & 18090101 & Mono Lake & $\begin{array}{l}111 \\
111 \mathrm{~A} \\
111 \mathrm{~B} \\
112 \\
115\end{array}$ & $\begin{array}{l}\text { Alkali Valley (Mineral) } \\
\text { Northern Part } \\
\text { Southern Part } \\
\text { Mono Valley } \\
\text { Adobe Valley }\end{array}$ \\
\hline 55 & 18090102 & Crowley Lake & 116 & Queen Valley \\
\hline \multicolumn{5}{|c|}{ Snake River Basin } \\
\hline 56 & 17040211 & Goose & 41 & Goose Creek Area \\
\hline 57 & 17040213 & Salmon Falls & 40 & Salmon Falls Creek Area \\
\hline 58 & 17050102 & Bruneau & $\begin{array}{l}38 \\
39\end{array}$ & $\begin{array}{l}\text { Bruneau River Area } \\
\text { Jarbidge River Area }\end{array}$ \\
\hline 59 & 17050104 & Upper Owyhee & $\begin{array}{l}35^{\mathrm{a}} \\
37\end{array}$ & $\begin{array}{l}\text { South Fork Owyhee River Area } \\
\text { Owyhee River Area }\end{array}$ \\
\hline 60 & 17050105 & South Fork Owyhee & $\begin{array}{l}35^{b} \\
36\end{array}$ & $\begin{array}{l}\text { South Fork Owyhee River Area } \\
\text { Independence Valley }\end{array}$ \\
\hline 61 & 17050106 & East Little Owyhee & $34^{b}$ & Little Owyhee River Area \\
\hline 62 & 17050107 & Middle Owyhee & $34^{\mathrm{a}}$ & Little Owyhee River Area \\
\hline
\end{tabular}


Table 1. National hydrologic cataloging units and corresponding Nevada hydrographic areas, grouped by Nevada regions and basins-Continued

\begin{tabular}{|c|c|c|c|c|}
\hline \multirow{2}{*}{$\begin{array}{l}\text { Map } \\
\text { number } \\
\text { (fig. 1) }\end{array}$} & \multicolumn{2}{|c|}{ Hydrologic cataloging unlt } & \multicolumn{2}{|r|}{ Nevada hydrographlc area } \\
\hline & Number & Name & Number & Name \\
\hline \multicolumn{5}{|c|}{ Northwest Region } \\
\hline 63 & 16040204 & Massacre Lake & $\begin{array}{r}8 \\
9 \\
12 \\
15 \\
16\end{array}$ & $\begin{array}{l}\text { Massacre Valley Lake } \\
\text { Long Valley } \\
\text { Mosquito Valley } \\
\text { Boulder Valley } \\
\text { Duck Lake Valley }\end{array}$ \\
\hline 64 & 16040205 & Thousand-Virgin & $\begin{array}{l}2 \\
3 \\
4\end{array}$ & $\begin{array}{l}\text { Continental Lake Valley } \\
\text { Gridley Lake Valley } \\
\text { Virgin Valley }\end{array}$ \\
\hline 65 & 17120007 & Warner Lakes & $\begin{array}{l}11 \\
13\end{array}$ & $\begin{array}{l}\text { Coleman Valley } \\
\text { Warner Valley }\end{array}$ \\
\hline 66 & 17120008 & Guano & $\begin{array}{r}5 \\
6 \\
7 \\
10\end{array}$ & $\begin{array}{l}\text { Sage Hen Valley } \\
\text { Guano Valley } \\
\text { Swan Lake Valley } \\
\text { Macy Flat }\end{array}$ \\
\hline 67 & 17120009 & Alvord Lake & 1 & Pueblo Valley \\
\hline 68 & 18080001 & Suprise Valley & 14 & Suprise Valley \\
\hline \multicolumn{5}{|c|}{ Western Region } \\
\hline 69 & 18080003 & Honey-Eagle Lakes & $\begin{array}{l}92 \\
92 \mathrm{~A} \\
92 \mathrm{~B} \\
93 \\
94 \\
95 \\
96 \\
97 \\
98 \\
99 \\
100 \\
100 \mathrm{~A}\end{array}$ & $\begin{array}{l}\text { Lemmon Valley } \\
\text { Western Part } \\
\text { Eastern Part } \\
\text { Antelope Valley } \\
\text { Bedell Flat } \\
\text { Dry Valley } \\
\text { Newcomb Lake Valley } \\
\text { Honey Lake Valley } \\
\text { Skedaddle Creek Valley } \\
\text { Red Rock Valley } \\
\text { Cold Spring Valley } \\
\text { Long Valley }\end{array}$ \\
\hline \multicolumn{5}{|c|}{ Death Valley Basin } \\
\hline 70 & 18090201 & Eureka-Saline Valleys & $232^{\mathrm{b}}$ & Oriental Wash \\
\hline 71 & 18090202 & Upper Amargosa & $\begin{array}{l}225 \\
226 \\
227 \\
227 \mathrm{~A} \\
227 \mathrm{~B} \\
228 \\
229 \\
230\end{array}$ & $\begin{array}{l}\text { Mercury Valley } \\
\text { Rock Valley } \\
\text { Fortymile Canyon } \\
\text { Jackass Flats } \\
\text { Buckboard Mesa } \\
\text { Oasis Valley } \\
\text { Crater Flat } \\
\text { Amargosa Desert }\end{array}$ \\
\hline 72 & 18090203 & Death Valley-Lower Amargosa & $\begin{array}{l}231 \\
232^{\mathrm{a}}\end{array}$ & $\begin{array}{l}\text { Grapevine Canyon } \\
\text { Oriental Wash }\end{array}$ \\
\hline
\end{tabular}

${ }^{\text {a }}$ Nonwater-use contributing part of this hydrographic area.

${ }^{b}$ Water-use contributing part of this hydrographic area. 
Table 2. Area, population, and population density in Nevada, by hydrologic cataloging unit, 1985

[Data from Wayne B. Solley, U.S. Geological Survey, written commun., 1986]

\begin{tabular}{|c|c|c|c|}
\hline $\begin{array}{c}\text { Map number } \\
\text { (fig. 1) }\end{array}$ & $\begin{array}{c}\text { Area } \\
\text { (square } \\
\text { miles) }\end{array}$ & $\begin{array}{l}\text { Population } \\
\text { (thousands) }\end{array}$ & $\begin{array}{l}\text { Population density } \\
\text { (people per } \\
\text { square mile) }\end{array}$ \\
\hline \multicolumn{4}{|c|}{ Colorado River Basin } \\
\hline 1 & 1,166 & 2.05 & 1.8 \\
\hline 2 & 120 & 0 & 0 \\
\hline 3 & 1,174 & 2.64 & 2.2 \\
\hline 4 & 2,869 & 1.58 & .6 \\
\hline 5 & 1,718 & 2.41 & 1.4 \\
\hline 6 & 2,599 & 2.97 & 1.1 \\
\hline 7 & 1,876 & 546.36 & 220 \\
\hline 8 & 484 & 2.56 & 5.3 \\
\hline 9 & 418 & .63 & 1.5 \\
\hline Region & 12,424 & 561.20 & 45 \\
\hline \multicolumn{4}{|c|}{ Great Salt Lake Basin } \\
\hline 10 & 1,282 & .20 & .2 \\
\hline 11 & 716 & 2.60 & 3.6 \\
\hline 12 & 1,761 & .46 & .3 \\
\hline 13 & 126 & 0 & 0 \\
\hline Region & 3,885 & 3.26 & .8 \\
\hline \multicolumn{4}{|c|}{ Escalante Desert } \\
\hline 14 & 100 & 0 & 0 \\
\hline \multicolumn{4}{|c|}{ Humboldt River Basin } \\
\hline 15 & 2,734 & 16.06 & 5.9 \\
\hline 16 & 1,025 & 0 & 0 \\
\hline 17 & 1,250 & .54 & .4 \\
\hline 18 & 970 & .11 & .1 \\
\hline 19 & 3,223 & 4.82 & 1.5 \\
\hline 20 & 864 & .26 & .3 \\
\hline 21 & 2,386 & .67 & .3 \\
\hline 22 & 2,620 & 11.27 & 4.3 \\
\hline 23 & 1,848 & .89 & .5 \\
\hline Region & 16,920 & 34.62 & 2.0 \\
\hline \multicolumn{4}{|c|}{ Black Rock Desert Region } \\
\hline 24 & 2,949 & 1.80 & .6 \\
\hline 25 & 3,068 & .28 & $<.1$ \\
\hline 26 & 2,302 & .62 & .3 \\
\hline 27 & 44 & 0 & 0 \\
\hline Region & 8,363 & 2.70 & .3 \\
\hline
\end{tabular}


Table 2. Area, population, and population density in Nevada, by hydrologic cataloging unit, 1985-Continued

\begin{tabular}{|c|c|c|c|}
\hline $\begin{array}{c}\text { Map number } \\
\text { (fig. 1) }\end{array}$ & $\begin{array}{c}\text { Area } \\
\text { (square } \\
\text { miles) }\end{array}$ & $\begin{array}{l}\text { Population } \\
\text { (thousands) }\end{array}$ & $\begin{array}{l}\text { Population density } \\
\text { (people per } \\
\text { square mile) }\end{array}$ \\
\hline \multicolumn{4}{|c|}{ Truckee River Basin } \\
\hline 28 & 152 & 12.90 & 85 \\
\hline 29 & 725 & 195.52 & 270 \\
\hline 30 & 1,414 & 1.98 & 1.4 \\
\hline Region & 2,291 & 210.40 & 92 \\
\hline \multicolumn{4}{|c|}{ West-Central Region } \\
\hline 31 & 1,624 & 4.15 & 2.6 \\
\hline \multicolumn{4}{|c|}{ Carson River Basin } \\
\hline 32 & 478 & 49.91 & 100 \\
\hline 33 & 846 & 7.91 & 9.4 \\
\hline 34 & 2,152 & 15.30 & 7.1 \\
\hline Region & 3,476 & 73.12 & 21 \\
\hline \multicolumn{4}{|c|}{ Walker River Basin } \\
\hline 35 & 604 & .01 & $<.1$ \\
\hline 36 & 604 & 2.28 & 3.8 \\
\hline 37 & 1,086 & 6.77 & 6.2 \\
\hline 38 & 816 & 5.00 & 6.1 \\
\hline Region & 3,110 & 14.06 & 4.5 \\
\hline \multicolumn{4}{|c|}{ Central Region } \\
\hline 39 & 4,139 & .40 & .1 \\
\hline 40 & 2,038 & 1.02 & .5 \\
\hline 41 & 2,068 & 3.75 & 1.8 \\
\hline 42 & 1,917 & 1.23 & .6 \\
\hline 43 & 3,275 & .96 & .3 \\
\hline 44 & 1,425 & .05 & $<.1$ \\
\hline 45 & 4,044 & .26 & $<.1$ \\
\hline 46 & 5,268 & 6.50 & 1.2 \\
\hline 47 & 2,061 & 0 & 0 \\
\hline 48 & 2,440 & .76 & .3 \\
\hline 49 & 3,131 & 1.22 & .4 \\
\hline 50 & 4,837 & .38 & $<.1$ \\
\hline 51 & 2,742 & .07 & $<.1$ \\
\hline 52 & 5,123 & 3.52 & .7 \\
\hline 53 & 2,011 & 17.94 & 8.9 \\
\hline 54 & 140 & 0 & 0 \\
\hline 55 & 67 & 0 & 0 \\
\hline Region & 46,726 & 38.06 & .8 \\
\hline
\end{tabular}


Table 2. Area, population, and population density in Nevada, by hydrologic cataloging unit, 1985-Continued

\begin{tabular}{|c|c|c|c|}
\hline $\begin{array}{c}\text { Map number } \\
\text { (fig. 1) }\end{array}$ & $\begin{array}{c}\text { Area } \\
\text { (square } \\
\text { miles) }\end{array}$ & $\begin{array}{l}\text { Populatlon } \\
\text { (thousands) }\end{array}$ & $\begin{array}{l}\text { Population density } \\
\text { (people per } \\
\text { square mile) }\end{array}$ \\
\hline \multicolumn{4}{|c|}{ Snake River Basin } \\
\hline 56 & 342 & 0.01 & $<0.1$ \\
\hline 57 & 1,208 & 1.09 & .9 \\
\hline 58 & 804 & .05 & .1 \\
\hline 59 & 541 & 1.40 & 2.6 \\
\hline 60 & 1,615 & .41 & .2 \\
\hline 61 & 714 & 0 & 0 \\
\hline 62 & 7 & 0 & 0 \\
\hline Region & 5,231 & 2.96 & .6 \\
\hline \multicolumn{4}{|c|}{ Northwest Region } \\
\hline 63 & 1,265 & .16 & .1 \\
\hline 64 & 932 & .02 & $<.1$ \\
\hline 65 & 121 & 0 & 0 \\
\hline 66 & 455 & 0 & 0 \\
\hline 67 & 130 & .04 & .3 \\
\hline 68 & 243 & 0 & 0 \\
\hline Region & 3,146 & .22 & $<.1$ \\
\hline \multicolumn{4}{|c|}{ Western Region } \\
\hline 69 & 636 & 20.23 & 32 \\
\hline \multicolumn{4}{|c|}{ Death Valley Basin } \\
\hline 70 & 7 & 0 & 0 \\
\hline 71 & 2,231 & 2.76 & 1.2 \\
\hline 72 & 363 & .01 & 0 \\
\hline Region & 2,601 & 2.77 & 1.1 \\
\hline STATE & 110,533 & 967.76 & 8.8 \\
\hline
\end{tabular}


Table 3. Area, population, and population density in Nevada by county, 1985

[Data from: Harrill and Worts, 1968; Bureau of Business and Economic Research, University of Nevada, Reno, written commun., 1986]

\begin{tabular}{|c|c|c|c|}
\hline $\begin{array}{l}\text { County } \\
\text { (fig. 3) }\end{array}$ & $\begin{array}{c}\text { Area } \\
\text { (square } \\
\text { miles) }\end{array}$ & $\begin{array}{l}\text { Population } \\
\text { (thousands) }\end{array}$ & $\begin{array}{c}\text { Population } \\
\text { density } \\
\text { (people per } \\
\text { square mile) }\end{array}$ \\
\hline Carson City & 163 & 35.40 & 220 \\
\hline Churchill & 4,997 & 15.45 & 3.1 \\
\hline Clark & 8,056 & 572.14 & 71 \\
\hline Douglas & 746 & 23.20 & 31 \\
\hline Elko & 17,127 & 22.85 & 1.3 \\
\hline Esmeralda & 3,596 & 1.38 & .4 \\
\hline Eureka & 4,164 & 1.45 & .4 \\
\hline Humboldt & 9,665 & 11.88 & 1.2 \\
\hline Lander & 5,523 & 4.50 & .8 \\
\hline Lincoln & 10,593 & 4.20 & .4 \\
\hline Lyon & 2,045 & 17.05 & 8.3 \\
\hline Mineral & 3,843 & 6.03 & 1.6 \\
\hline Nye & 18,251 & 14.85 & .8 \\
\hline Pershing & 6,012 & 3.61 & .6 \\
\hline Storey & 264 & 1.78 & 6.7 \\
\hline Washoe & 6,617 & 224.42 & 34 \\
\hline White Pine & 8,871 & 7.56 & .8 \\
\hline STATE & 110,533 & 967.76 & 8.8 \\
\hline
\end{tabular}




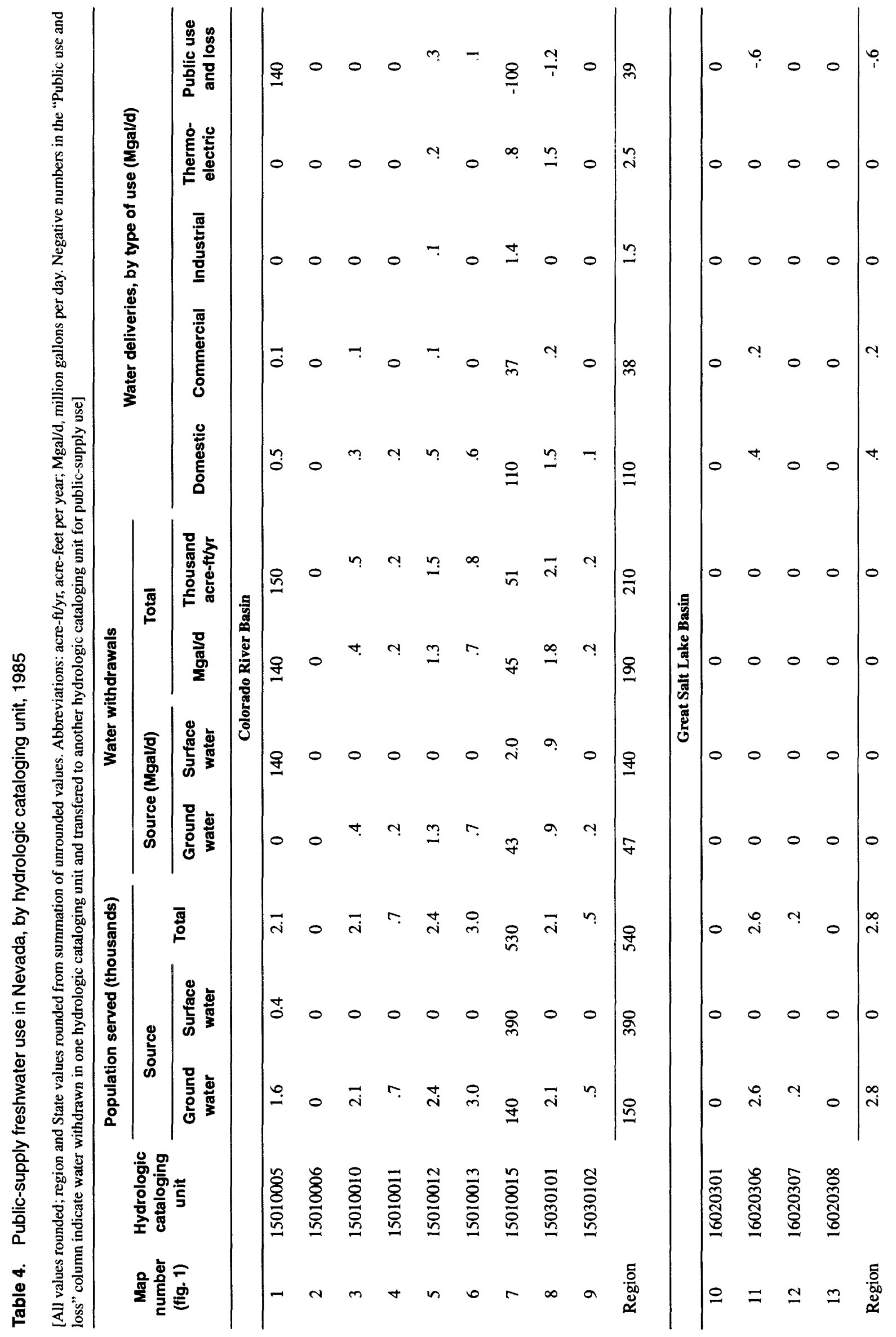




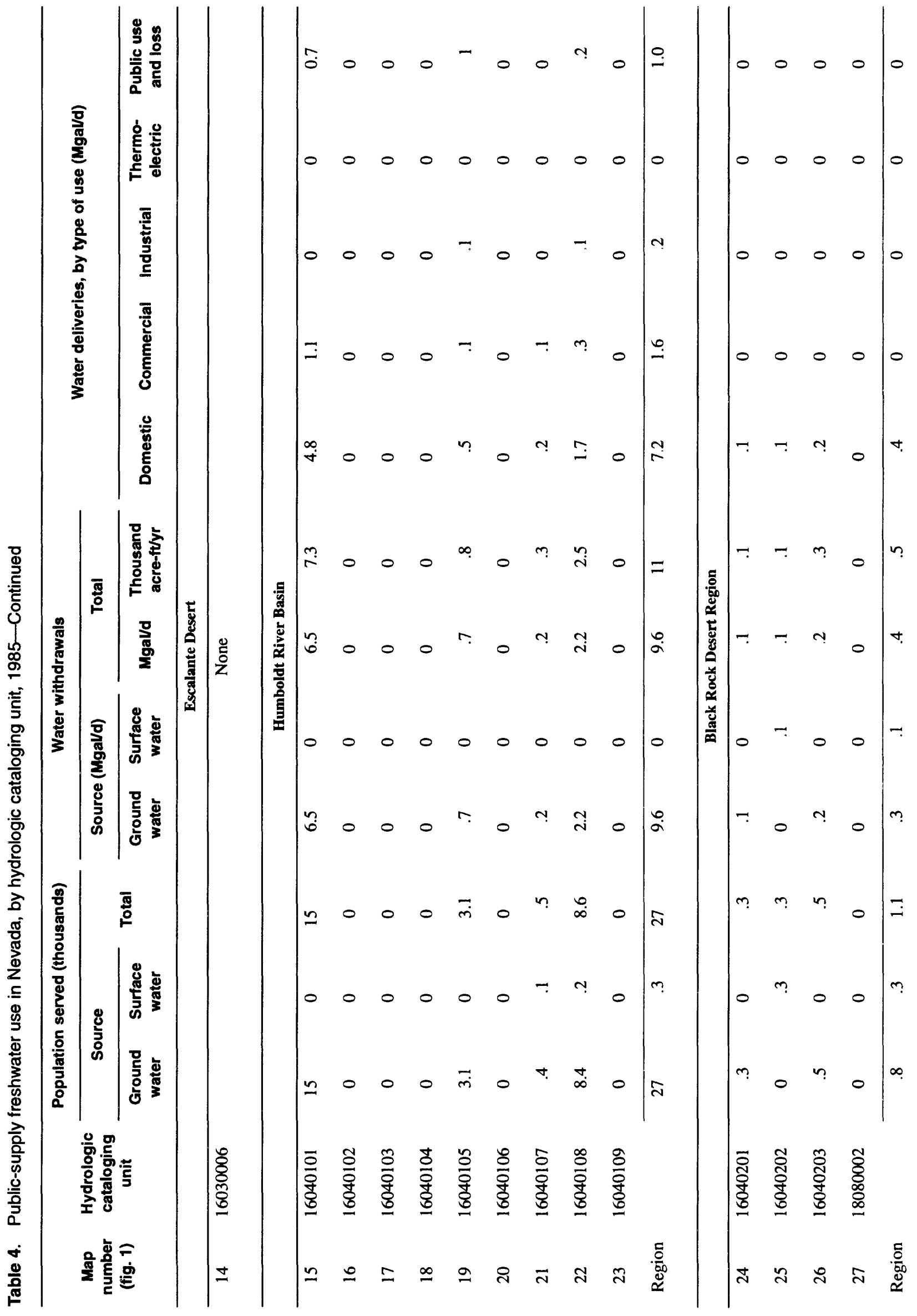




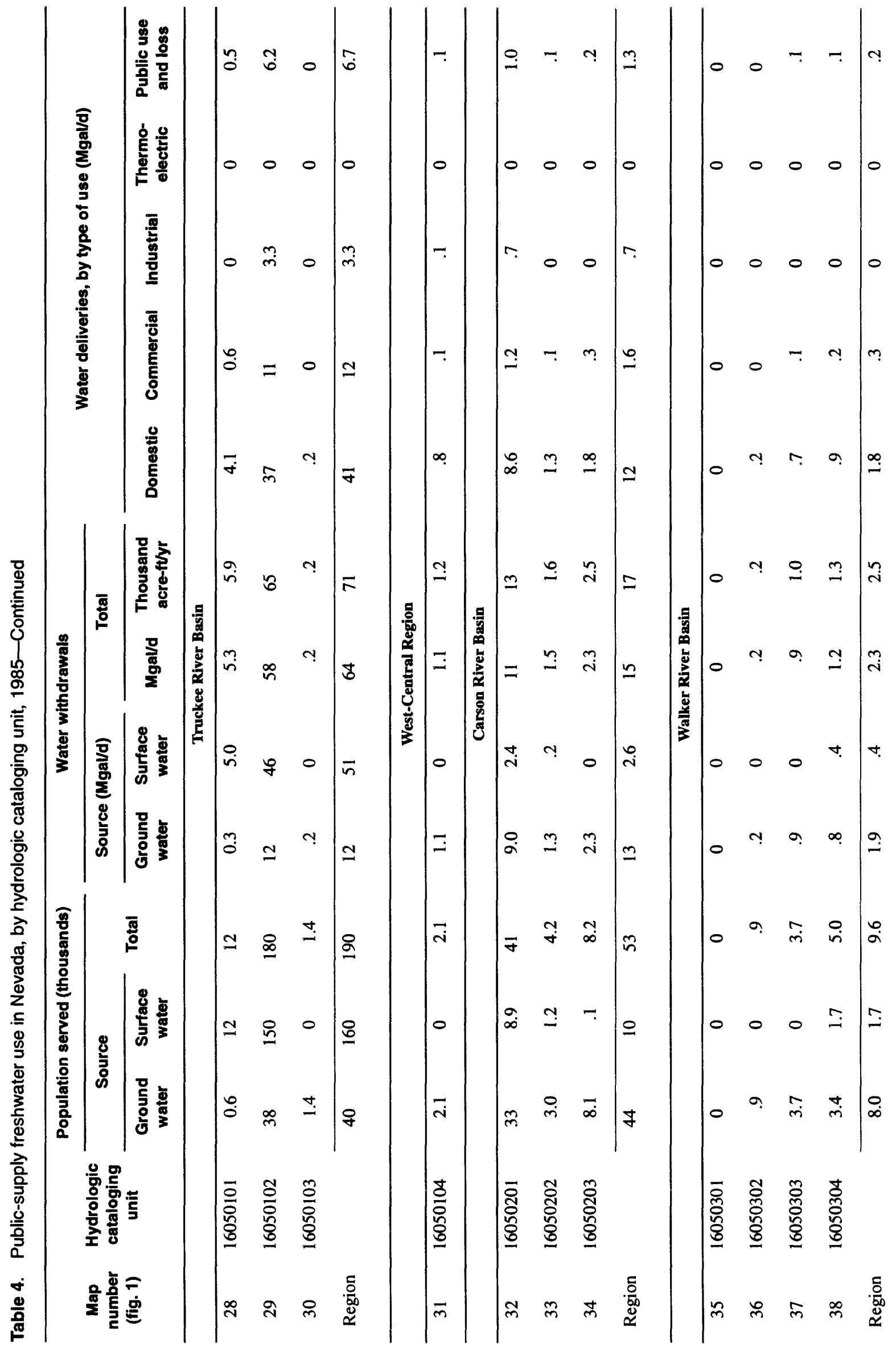




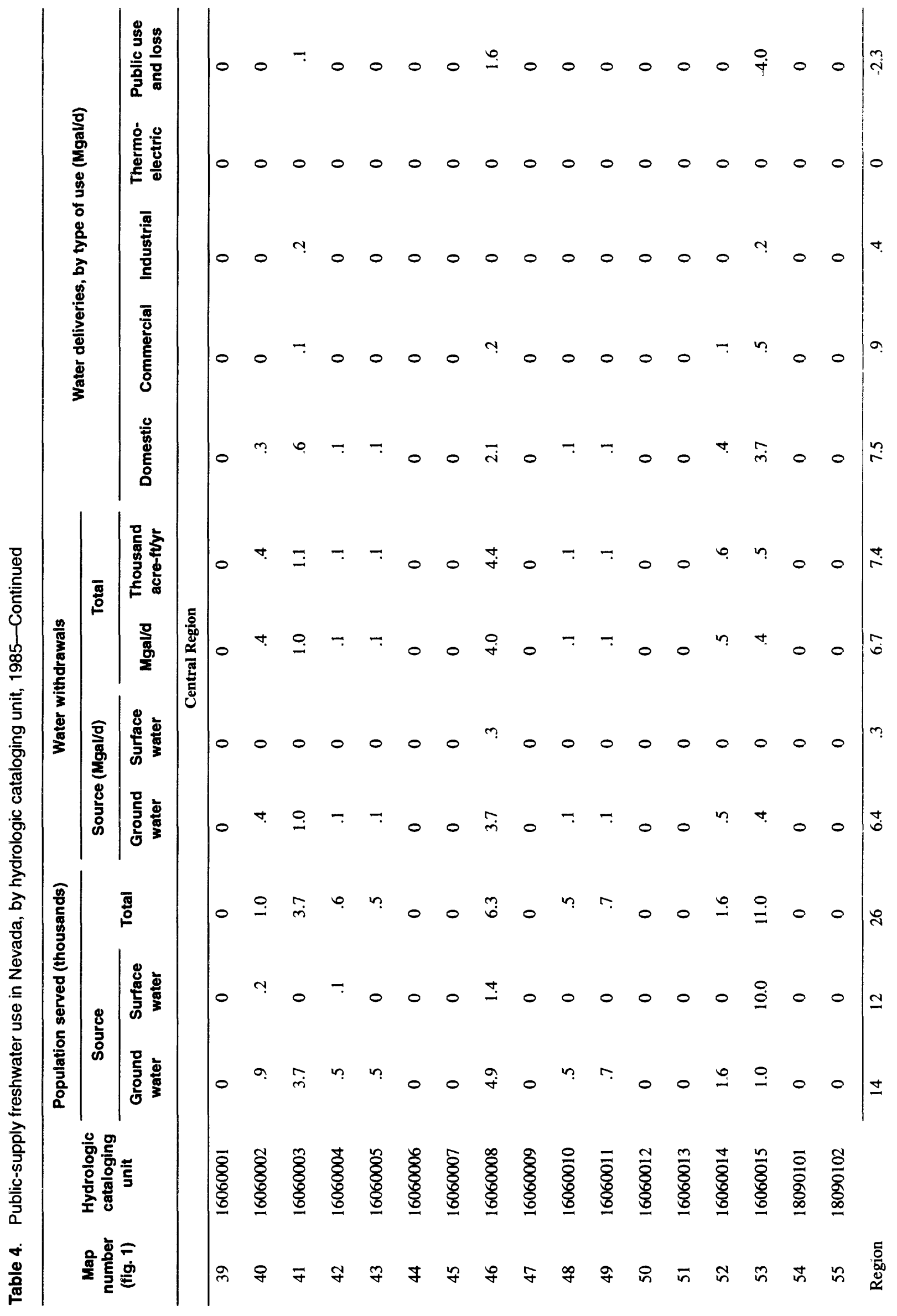




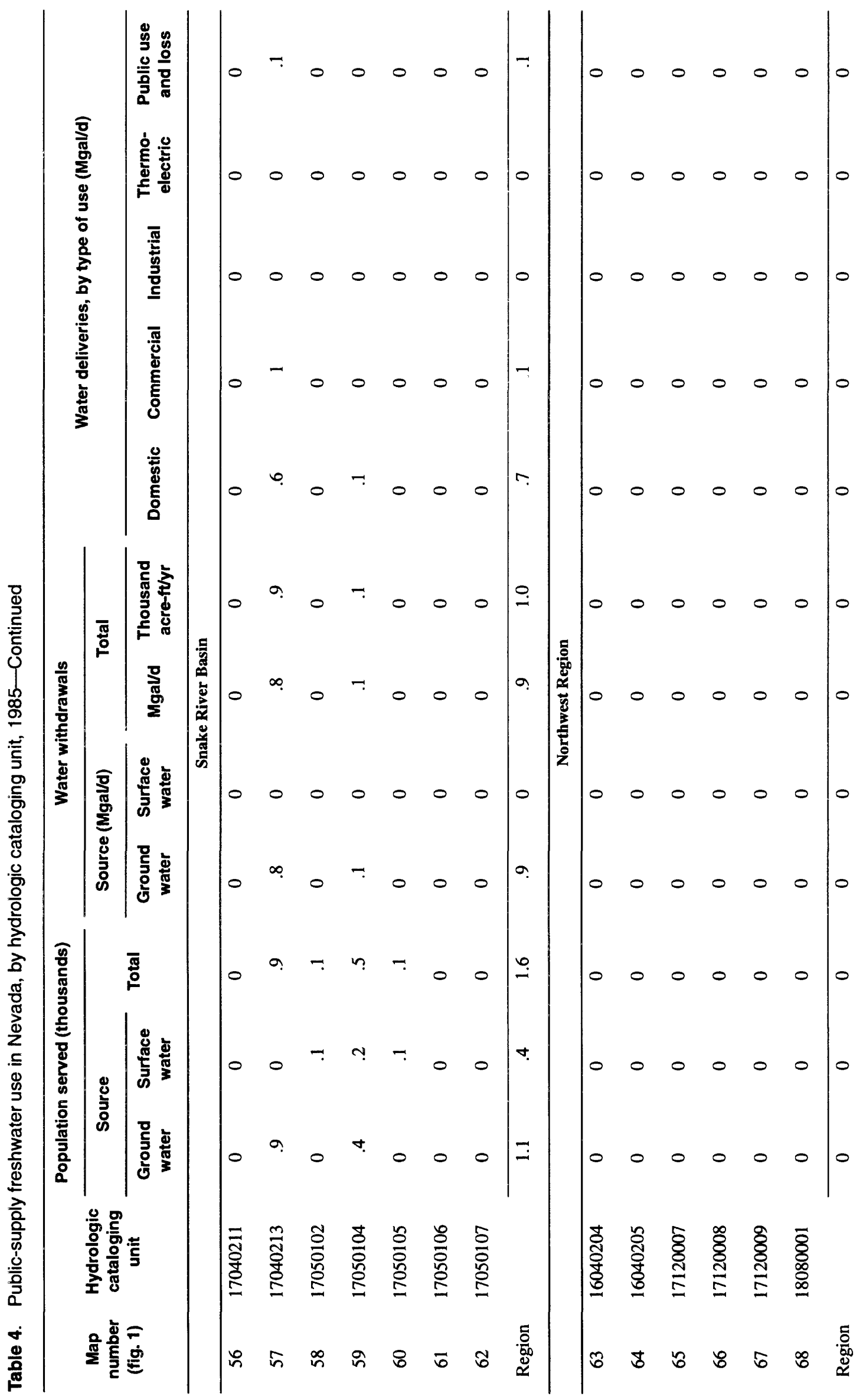




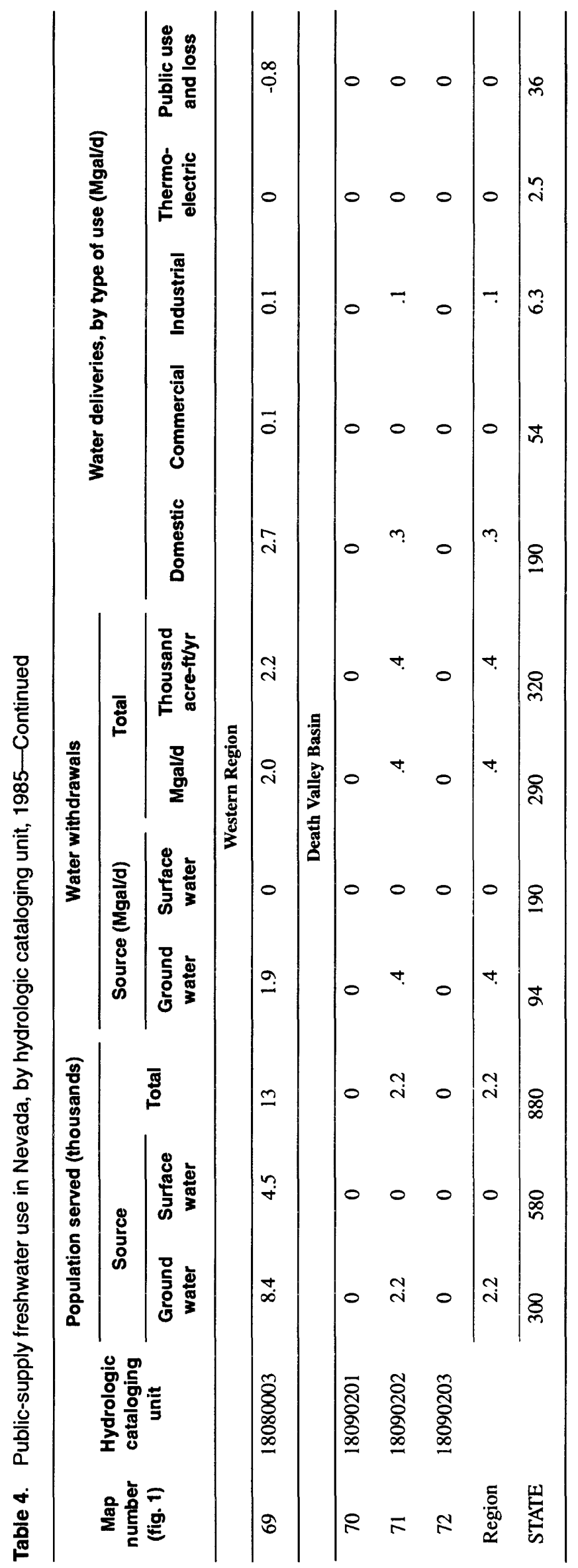




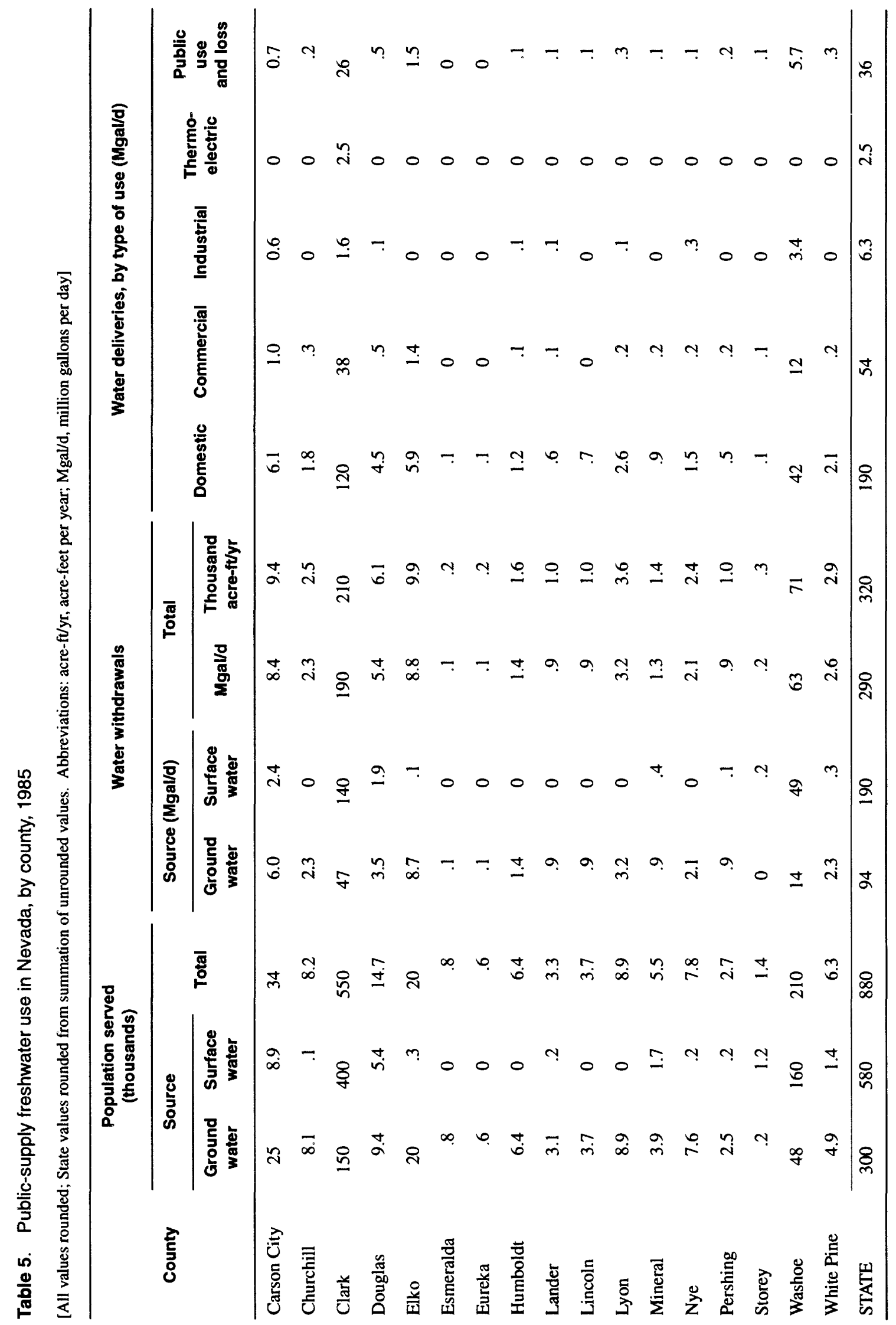




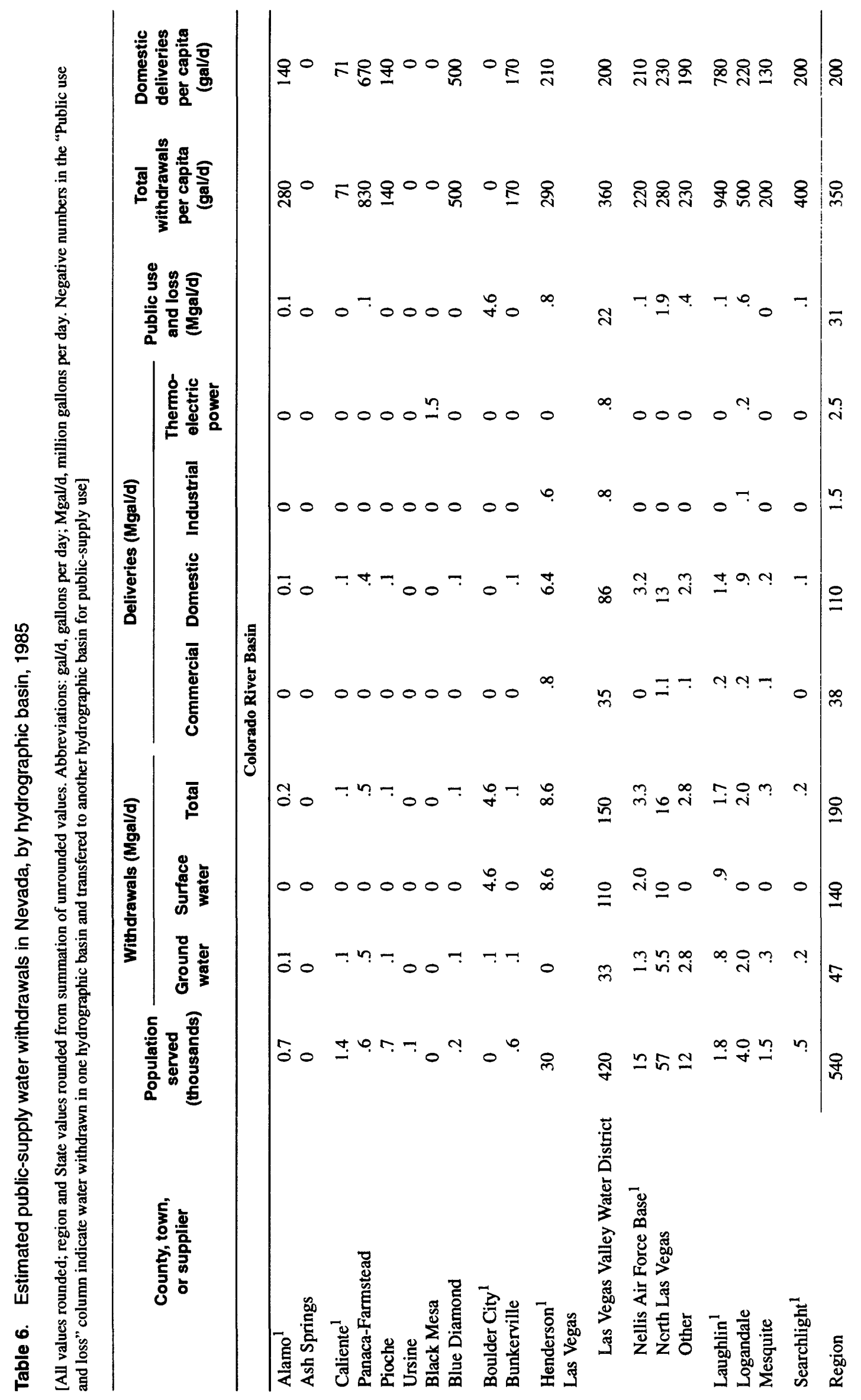




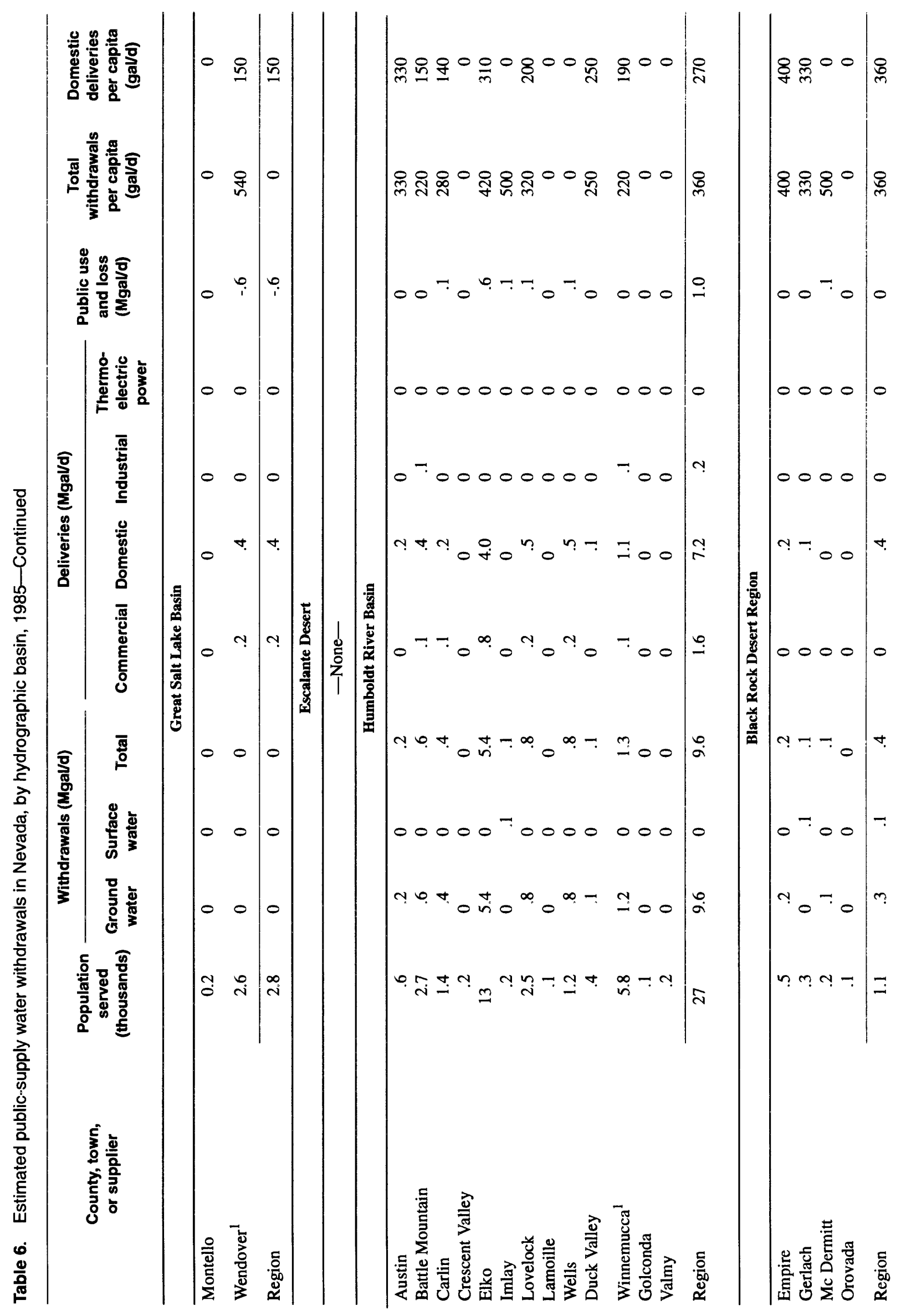




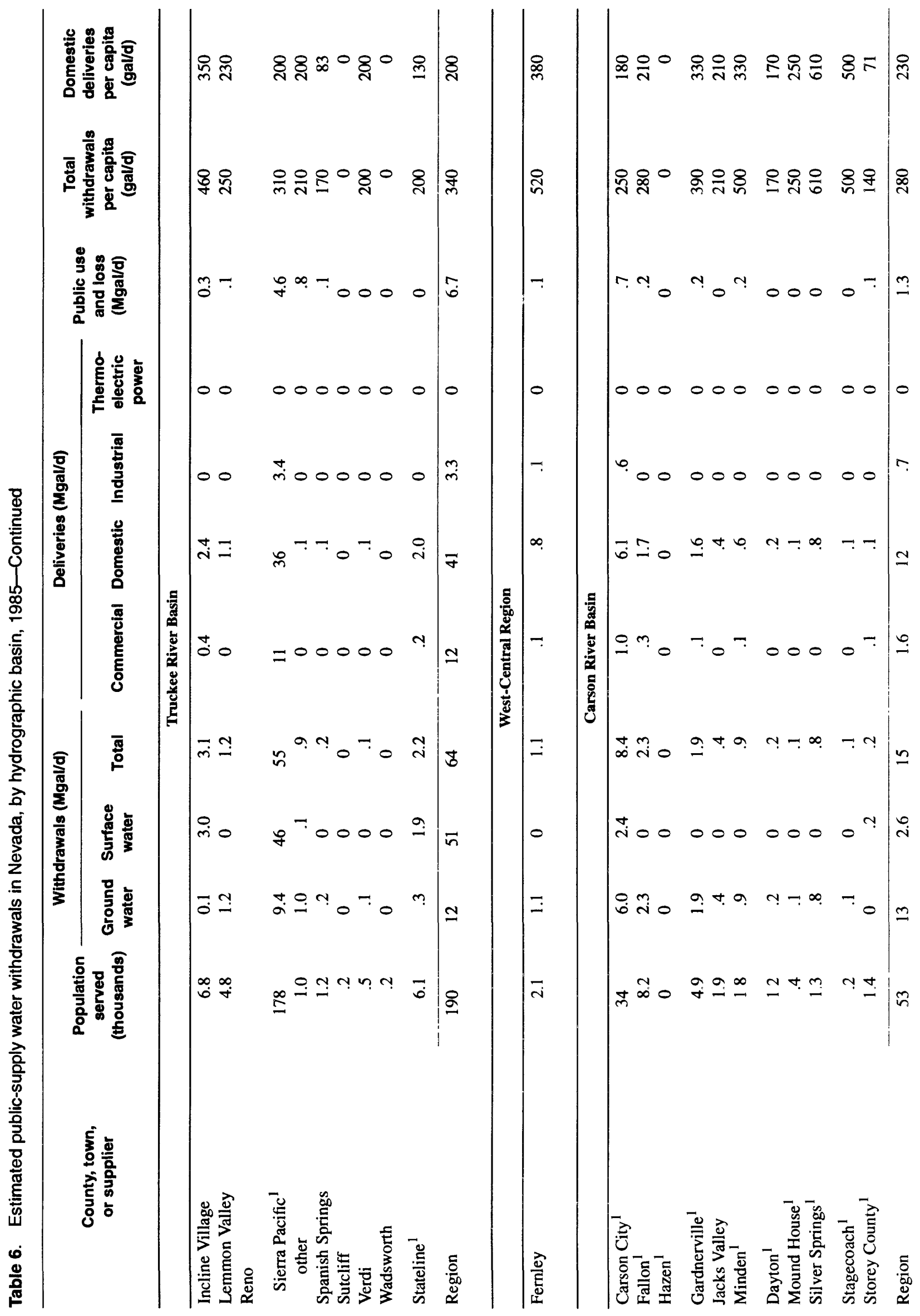




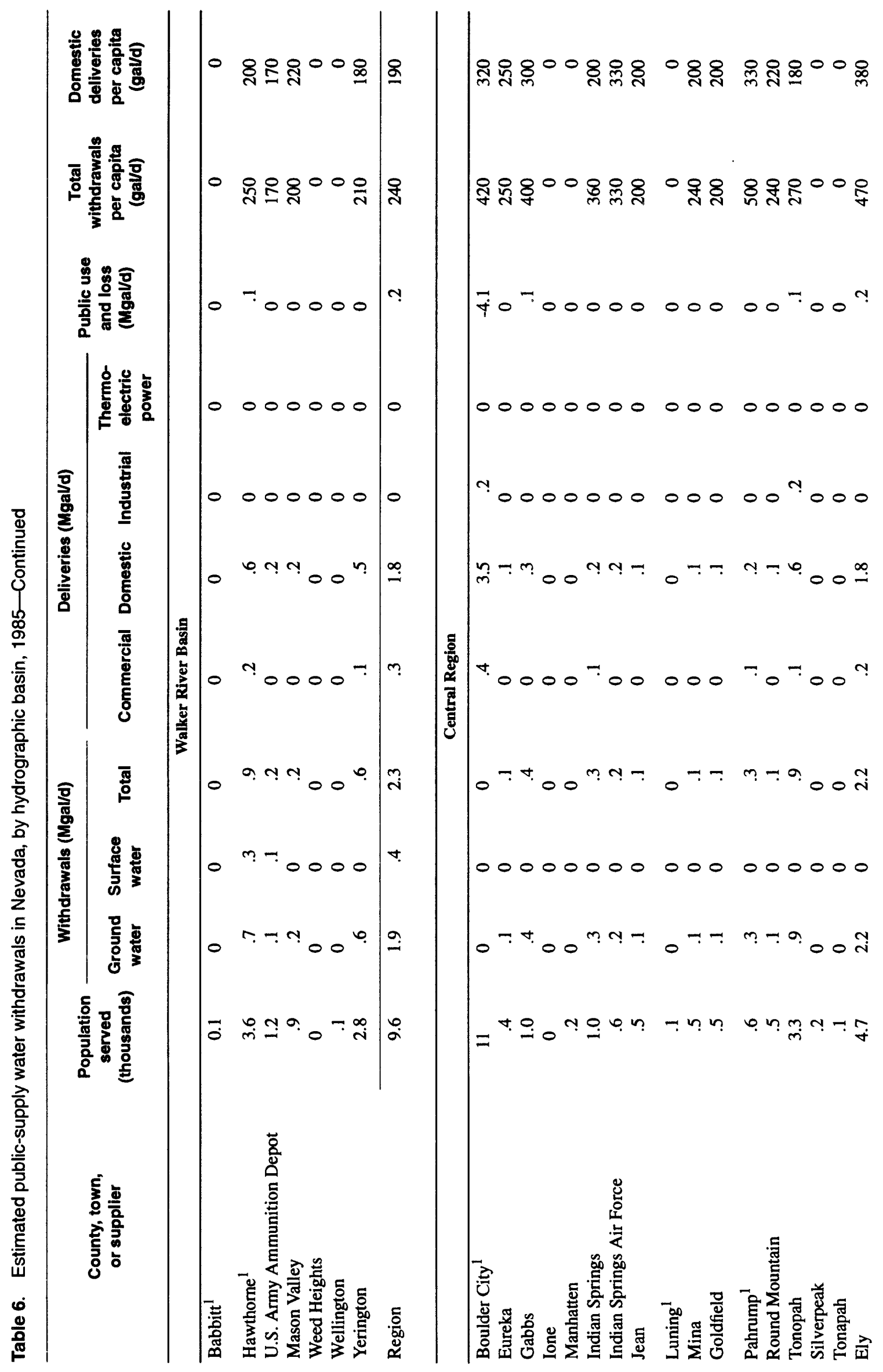




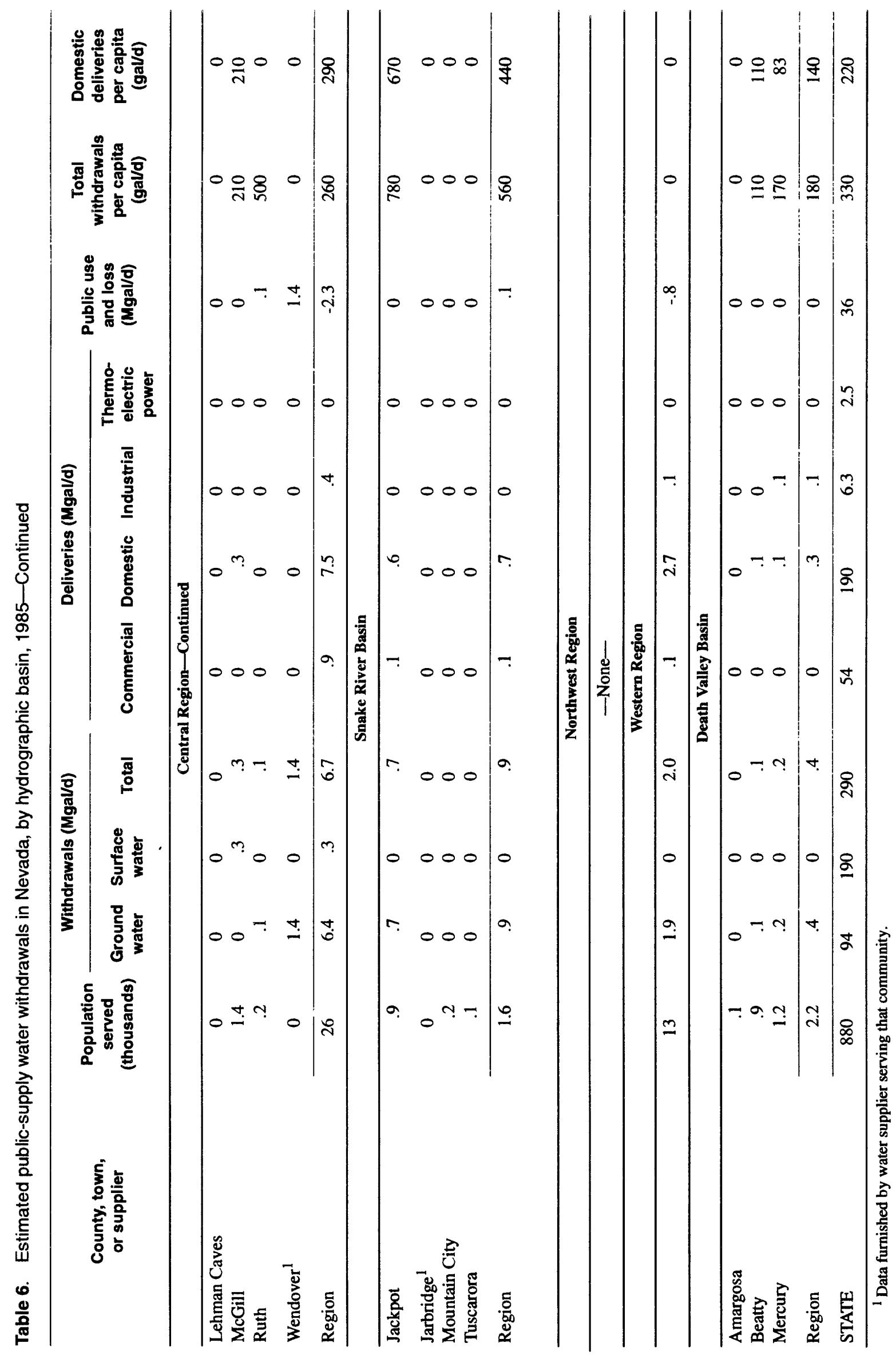




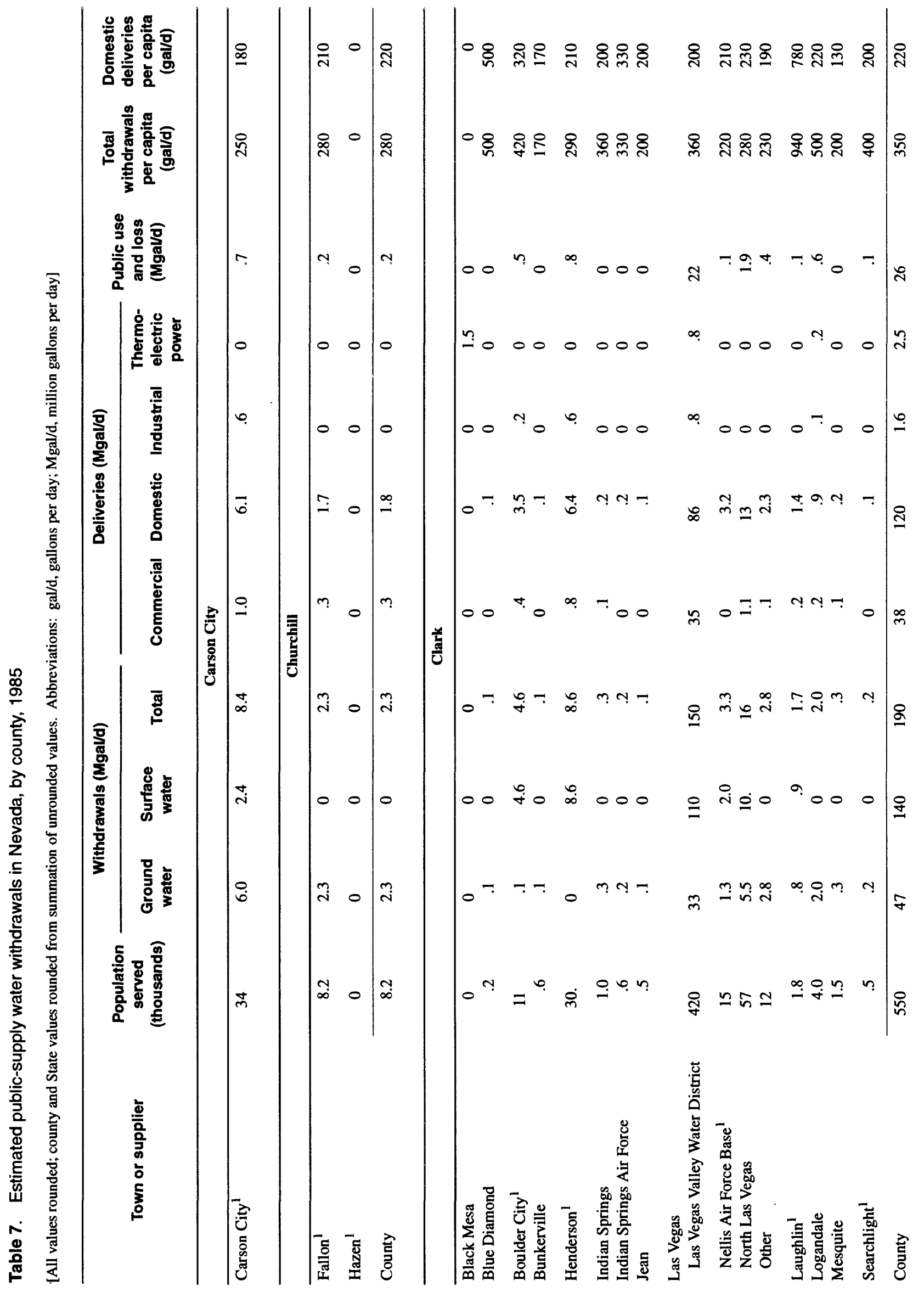




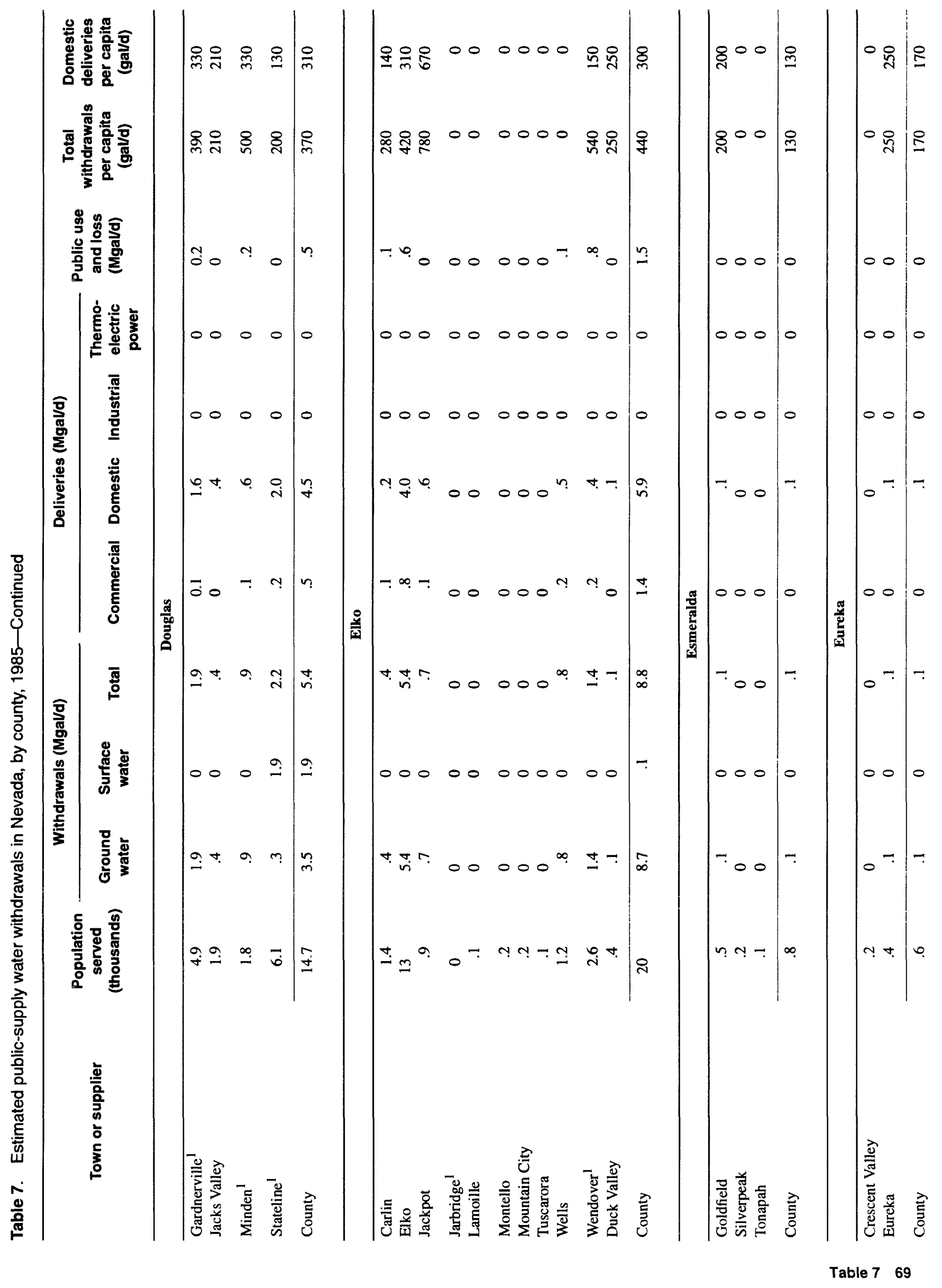




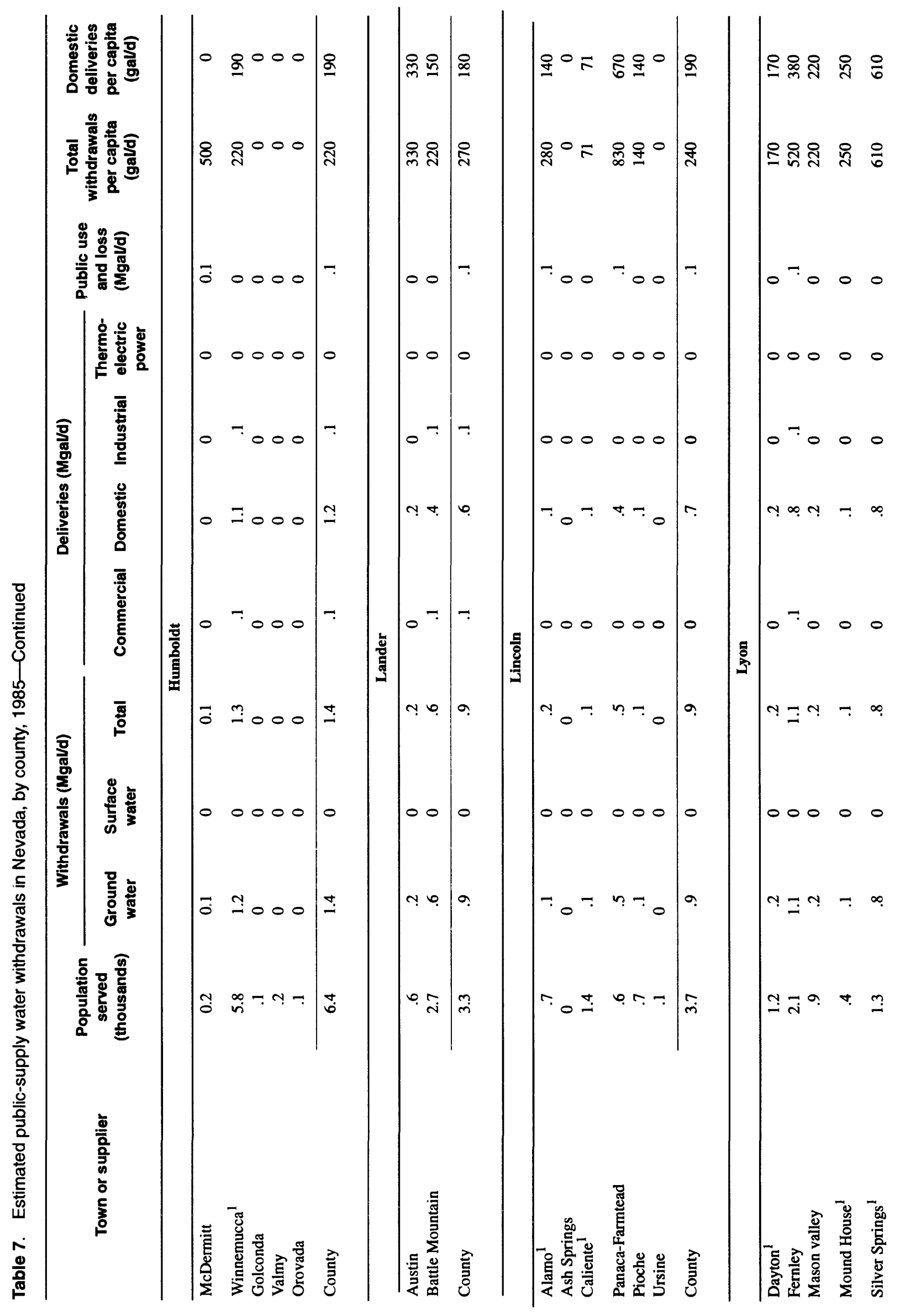




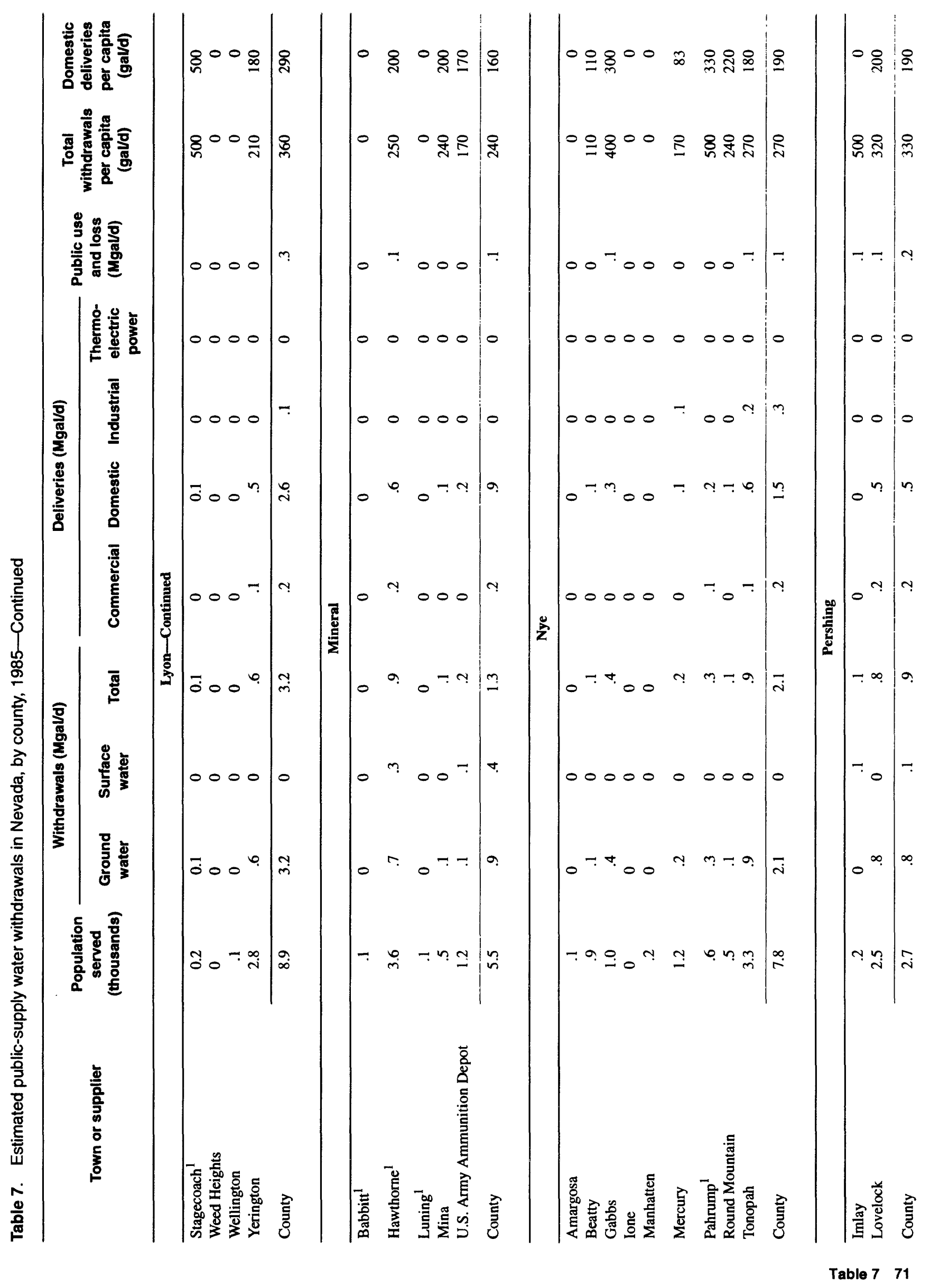




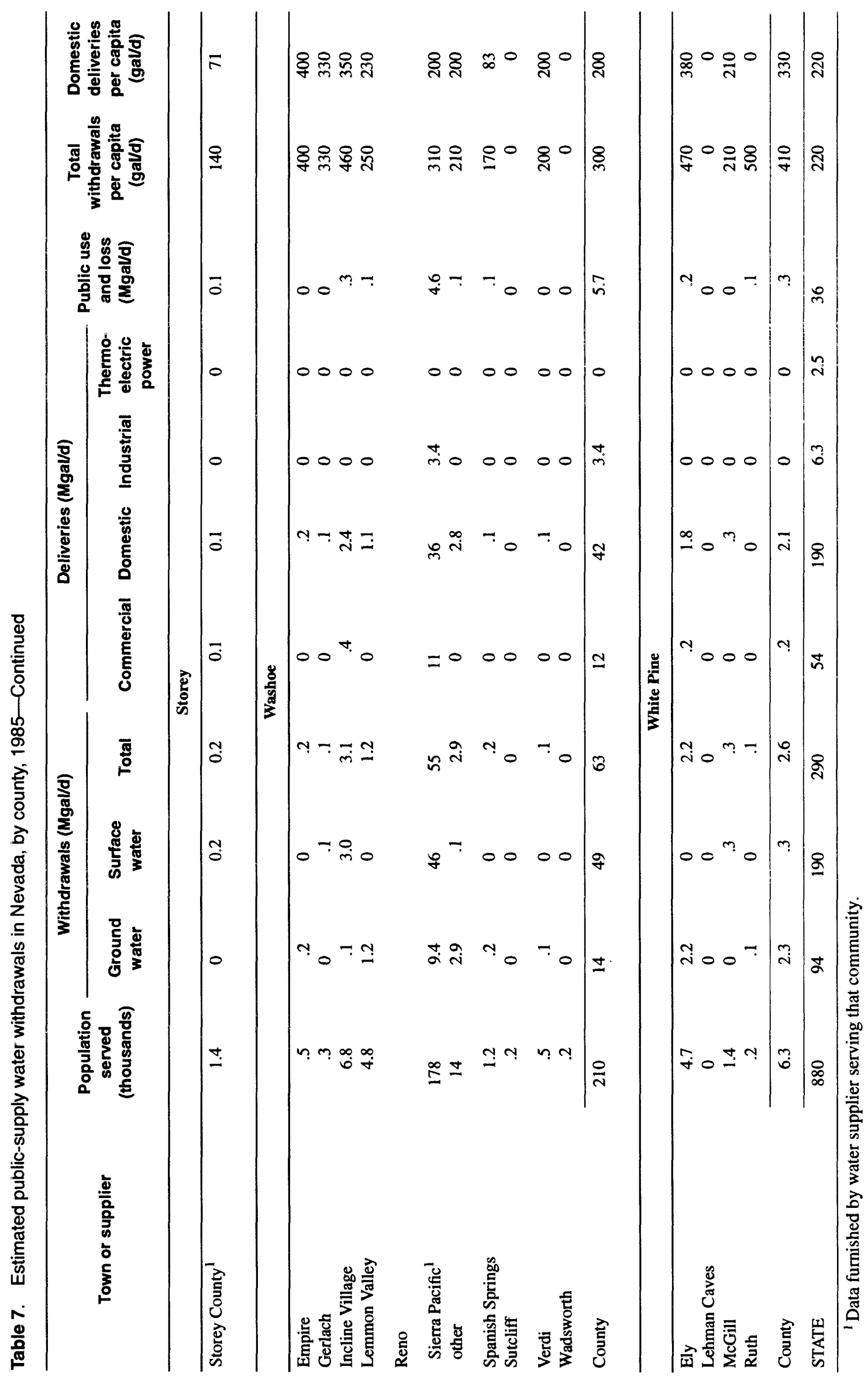




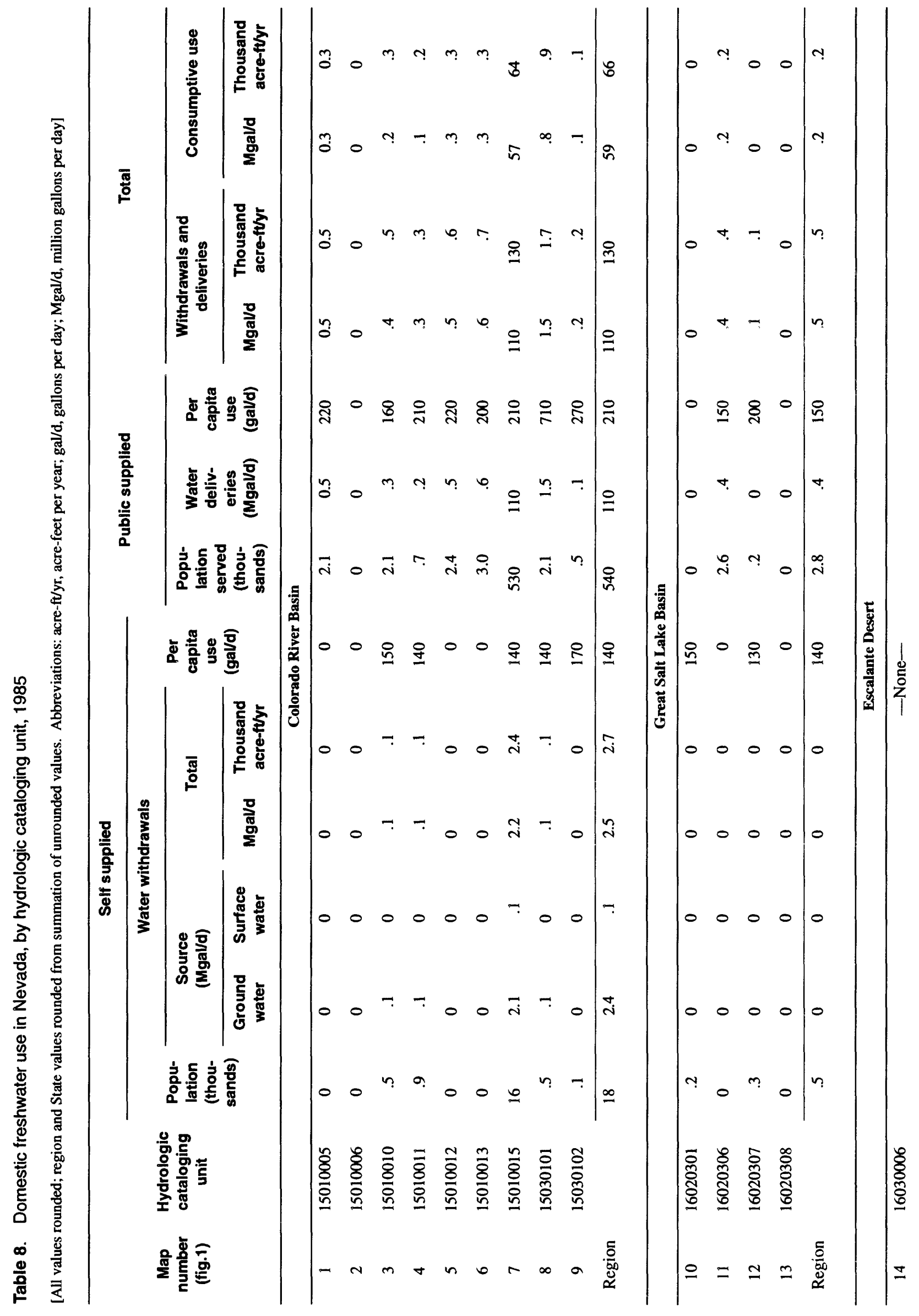




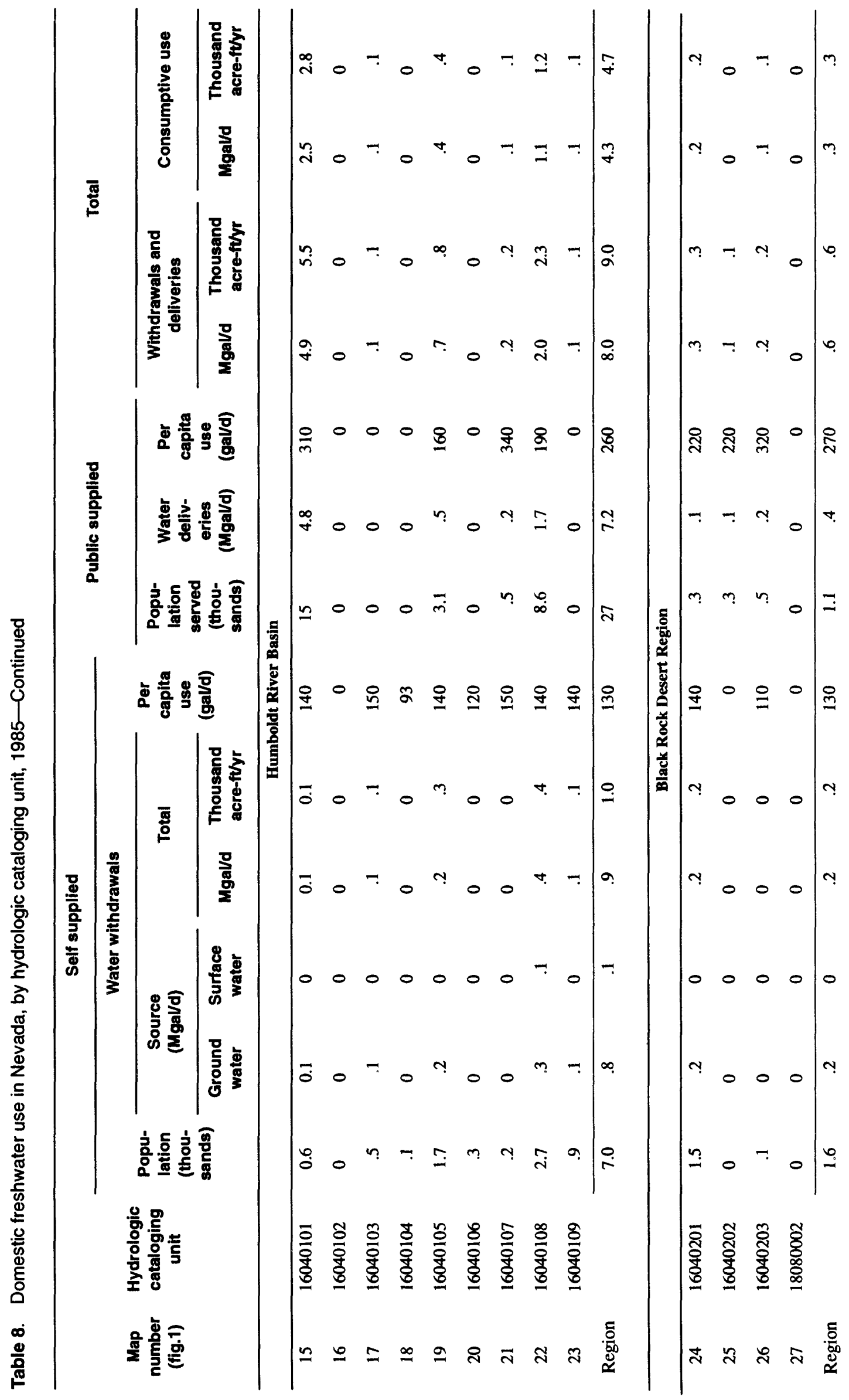




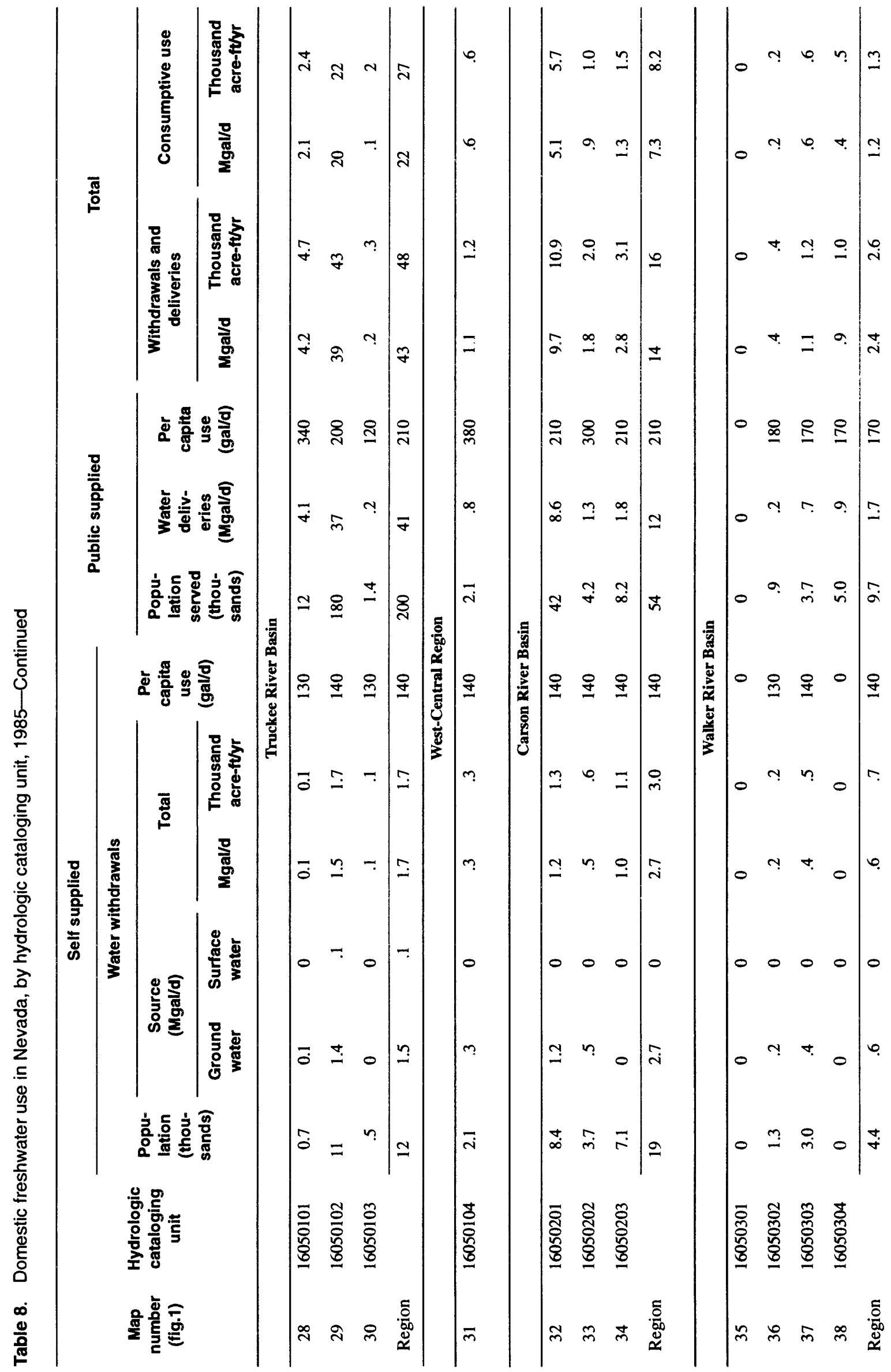




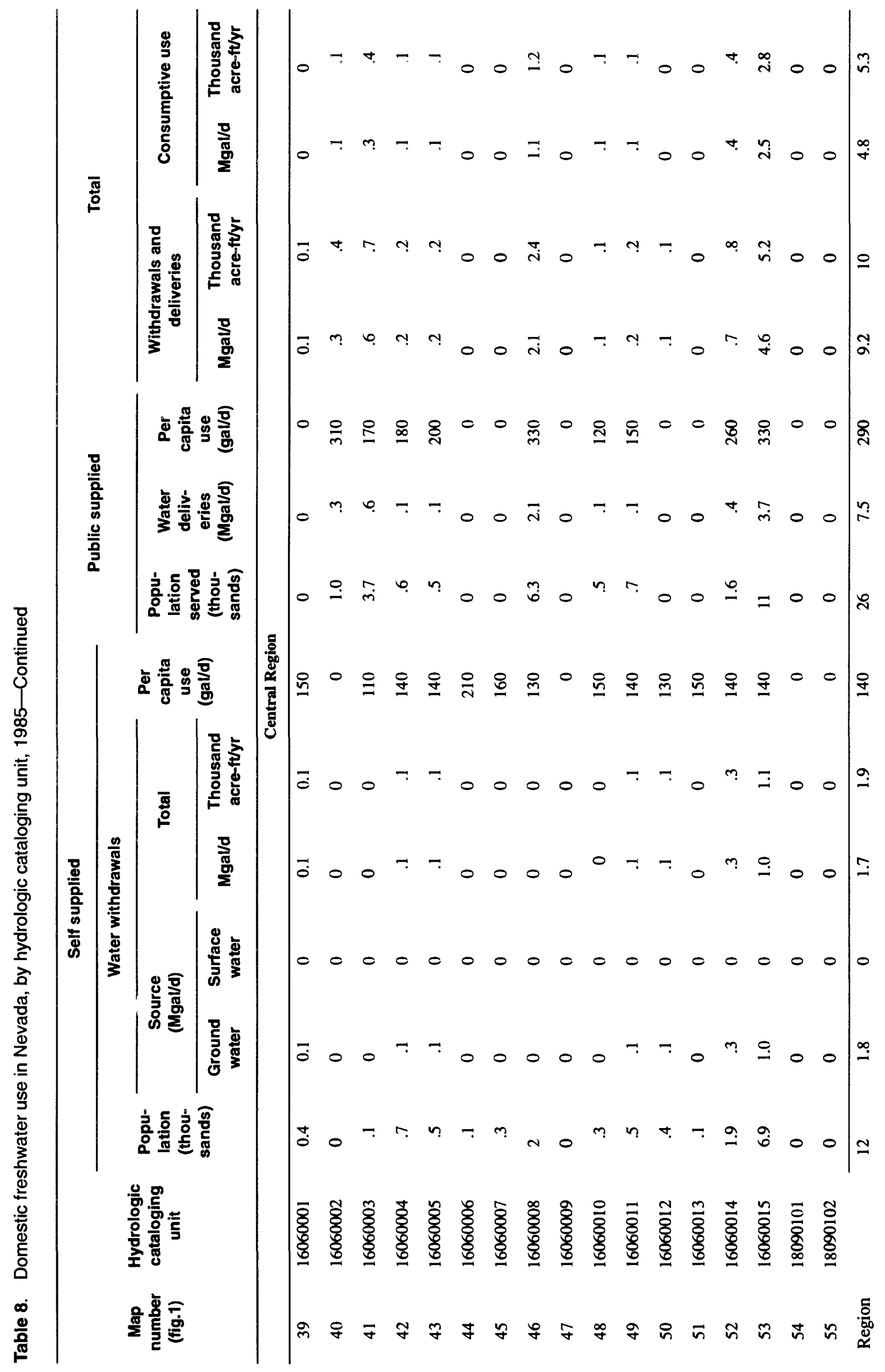




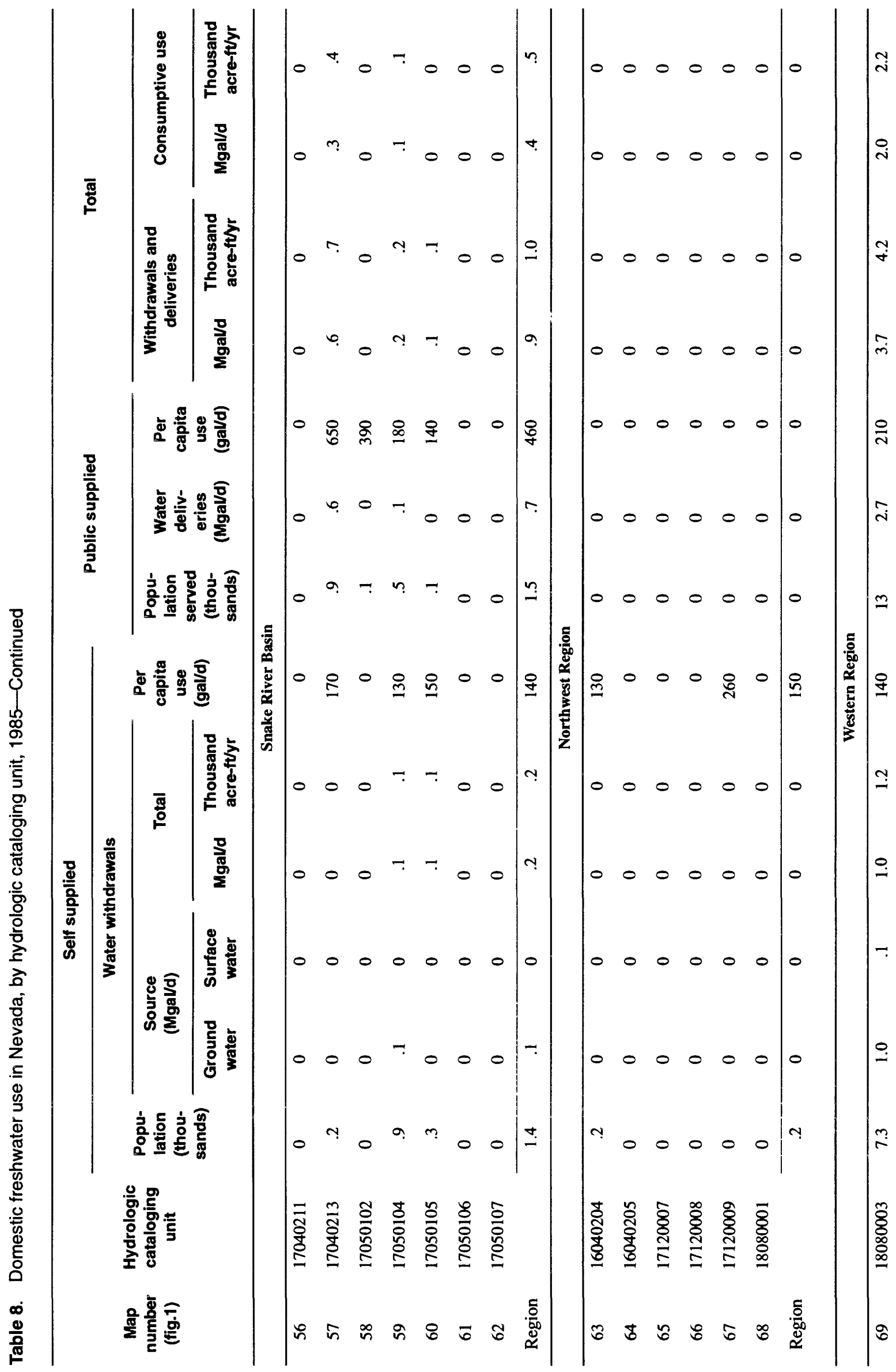




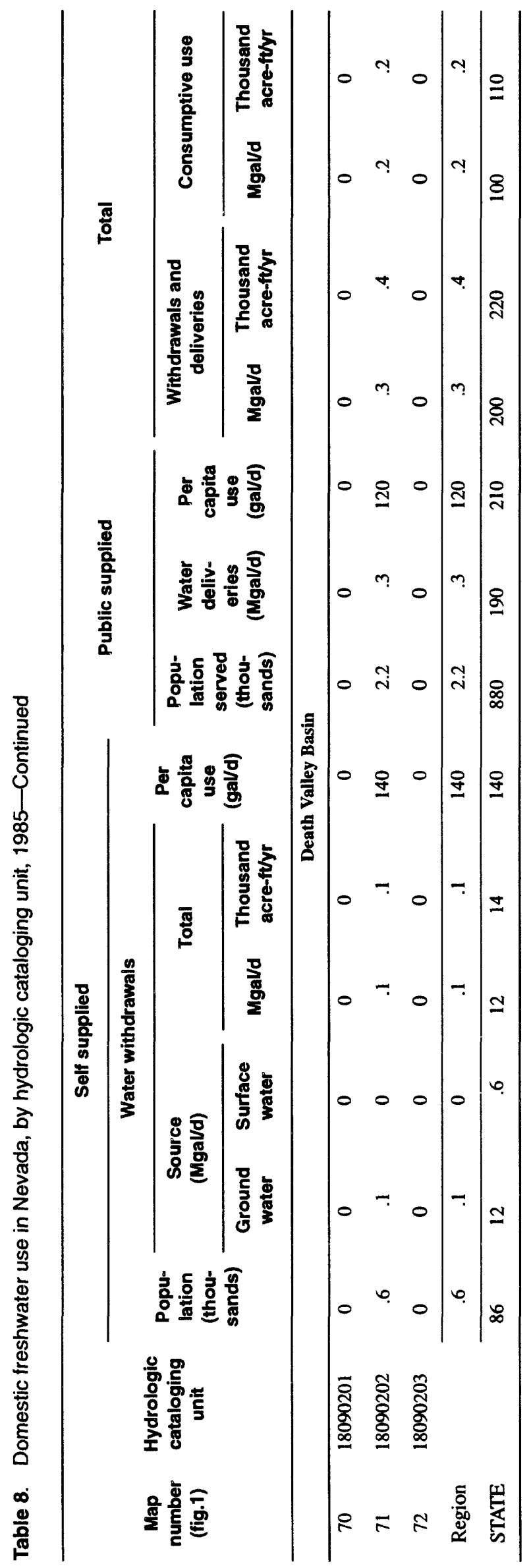




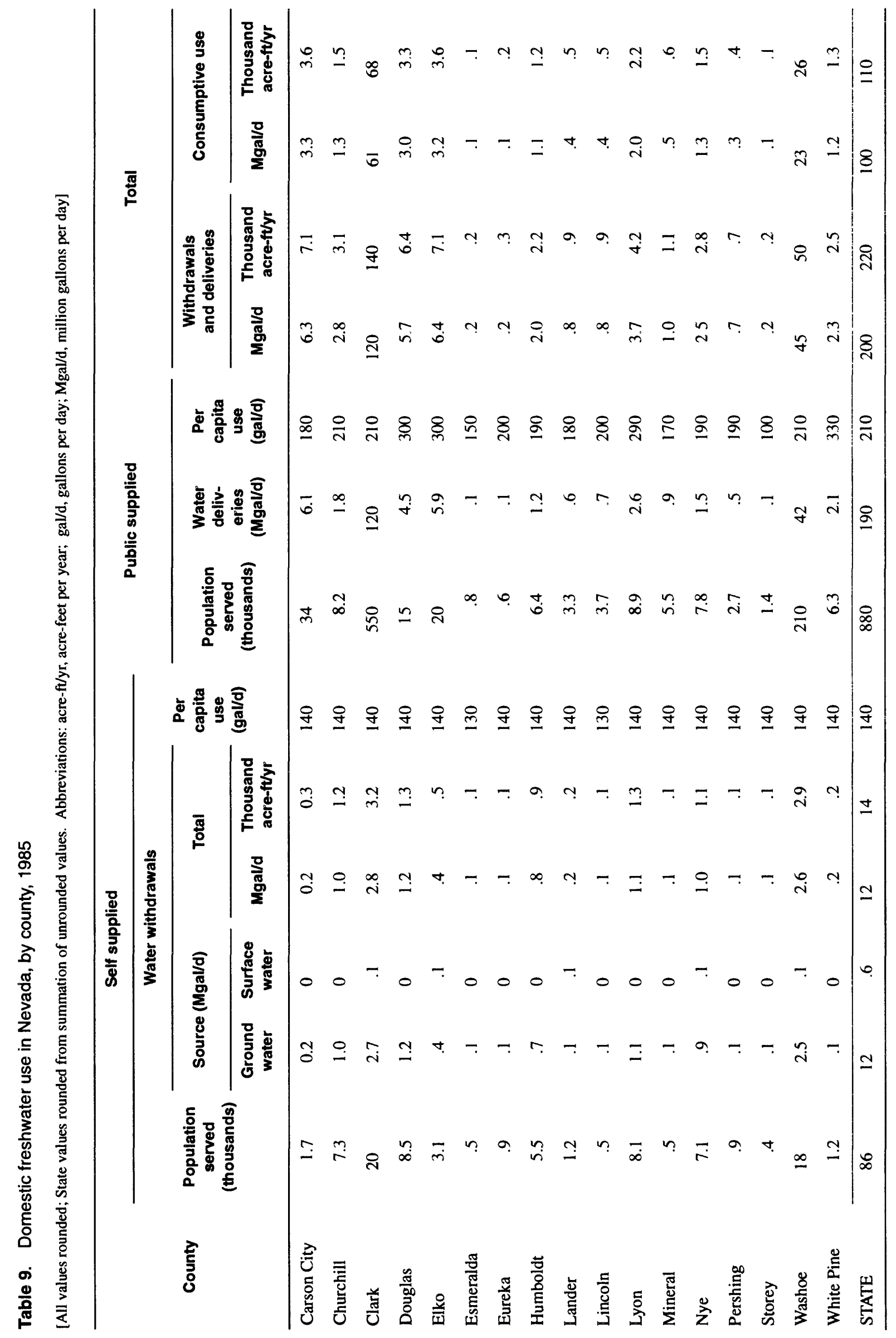


Table 10. Commerical freshwater use in Nevada, by hydrologic cataloging unit, 1985

[All values rounded; region and State values rounded from summation of unrounded values. Abbreviation: acre-ft/yr, acre-feet per year; Mgal/d, million gallons per day]

\begin{tabular}{|c|c|c|c|c|c|c|c|c|c|c|}
\hline \multirow{3}{*}{$\begin{array}{c}\text { Map } \\
\text { number } \\
\text { (fig.1) }\end{array}$} & \multirow{3}{*}{$\begin{array}{c}\text { Hydrologic } \\
\text { cataloging } \\
\text { unit }\end{array}$} & \multicolumn{4}{|c|}{ Self-supplied withdrawals } & \multirow{3}{*}{$\begin{array}{l}\text { Public- } \\
\text { supplied } \\
\text { deliveries } \\
\text { (Mgal/d) }\end{array}$} & \multicolumn{4}{|c|}{ Total } \\
\hline & & \multicolumn{2}{|c|}{ Source (Mgal/d) } & \multicolumn{2}{|c|}{ Total } & & \multicolumn{2}{|c|}{$\begin{array}{l}\text { Withdrawals and } \\
\text { deliveries }\end{array}$} & \multicolumn{2}{|c|}{ Consumptive use } \\
\hline & & $\begin{array}{l}\text { Ground } \\
\text { water }\end{array}$ & $\begin{array}{c}\text { Surface } \\
\text { water }\end{array}$ & (Mgal/d) & $\begin{array}{r}\text { (Thousand } \\
\text { acre-ft/yr) }\end{array}$ & & (Mgal/d) & $\begin{array}{l}\text { (Thousand } \\
\text { acre-ft/yr) }\end{array}$ & (Mgal/d) & $\begin{array}{r}\text { (Thousand } \\
\text { acre-ft/yr) }\end{array}$ \\
\hline \multicolumn{11}{|c|}{ Colorado River Basin } \\
\hline 1 & 15010005 & 0 & 0.2 & 0.2 & 0.3 & 0.1 & 0.3 & 0.3 & 0.1 & 0.1 \\
\hline 2 & 15010006 & 0 & 0 & 0 & 0 & 0 & 0 & 0 & 0 & 0 \\
\hline 3 & 15010010 & 0 & 0 & 0 & 0 & 1 & .1 & .1 & 0 & 0 \\
\hline 4 & 15010011 & 0 & 0 & 0 & 0 & 0 & 0 & 0 & 0 & 0 \\
\hline 5 & 15010012 & .1 & 0 & .1 & .1 & .1 & .2 & .2 & 0 & 0 \\
\hline 6 & 15010013 & 0 & 0 & 0 & 0 & 0 & 0 & 0 & 0 & 0 \\
\hline 7 & 15010015 & 5.2 & .1 & 5.4 & 6.0 & 37 & 42 & 47 & 8.5 & 9.5 \\
\hline 8 & 15030101 & .2 & 0 & .2 & .3 & .2 & .4 & .4 & .1 & .1 \\
\hline 9 & 15030102 & 0 & 0 & 0 & 0 & 0 & 0 & 0 & 0 & 0 \\
\hline Region & & 5.5 & .3 & 5.9 & 6.7 & 38 & 43 & 48 & 8.7 & 9.7 \\
\hline \multicolumn{11}{|c|}{ Great Salt Lake Basin } \\
\hline 10 & 16020301 & 0 & 0 & 0 & 0 & 0 & 0 & 0 & 0 & 0 \\
\hline 11 & 16020306 & 0 & 0 & 0 & 0 & .2 & .2 & .2 & 0 & 0 \\
\hline 12 & 16020307 & 0 & 0 & 0 & 0 & 0 & 0 & 0 & 0 & 0 \\
\hline 13 & 16020308 & 0 & 0 & 0 & 0 & 0 & 0 & 0 & 0 & 0 \\
\hline Region & & 0 & 0 & 0 & 0 & .2 & .2 & .2 & 0 & 0 \\
\hline \multicolumn{11}{|c|}{ Escalante Desert } \\
\hline 14 & 16030006 & & & & -None- & & & & & \\
\hline \multicolumn{11}{|c|}{ Humboldt River Basin } \\
\hline 15 & 16040101 & .4 & 0 & .4 & .4 & 1.1 & 1.4 & 1.6 & .3 & .3 \\
\hline 16 & 16040102 & 0 & 0 & 0 & 0 & 0 & 0 & 0 & 0 & 0 \\
\hline 17 & 16040103 & 0 & 0 & 0 & 0 & 0 & 0 & 0 & 0 & 0 \\
\hline 18 & 16040104 & 0 & 0 & 0 & 0 & 0 & 0 & 0 & 0 & 0 \\
\hline 19 & 16040105 & 0 & 0 & 0 & 0 & .1 & .1 & .1 & 0 & 0 \\
\hline 20 & 16040106 & 0 & 0 & 0 & 0 & 0 & 0 & 0 & 0 & 0 \\
\hline 21 & 16040107 & 0 & 0 & 0 & 0 & .1 & .1 & .1 & 0 & 0 \\
\hline 22 & 16040108 & 0 & 0 & 0 & 0 & .3 & .3 & .3 & .1 & .1 \\
\hline 23 & 16040109 & 0 & 0 & 0 & 0 & 0 & 0 & 0 & 0 & 0 \\
\hline Region & & .4 & 0 & .4 & .4 & 1.6 & 1.9 & 2.1 & .4 & .4 \\
\hline
\end{tabular}


Table 10. Commerical freshwater use in Nevada, by hydrologic cataloging unit, 1985-Continued

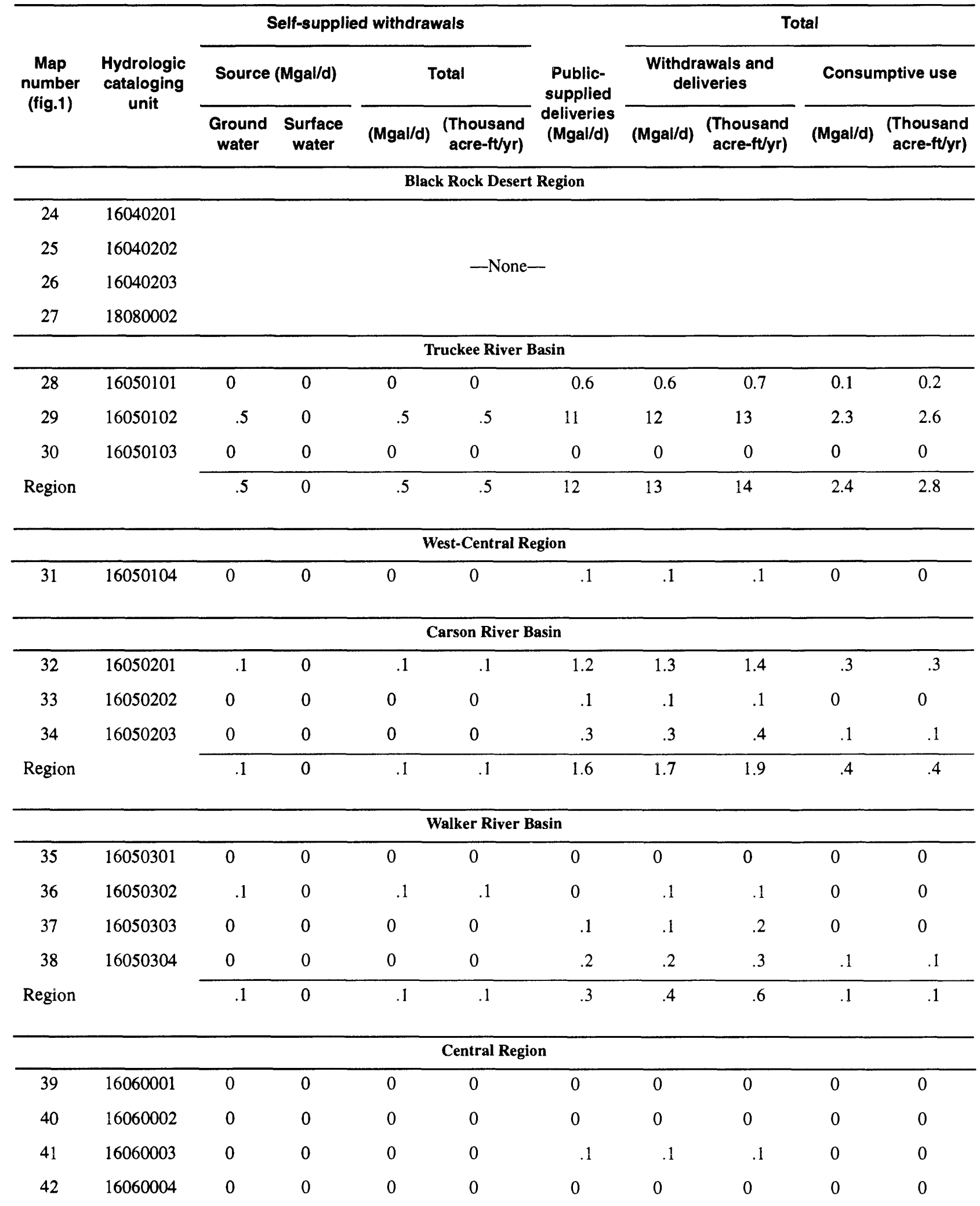


Table 10. Commerical freshwater use in Nevada, by hydrologic cataloging unit, 1985-Continued

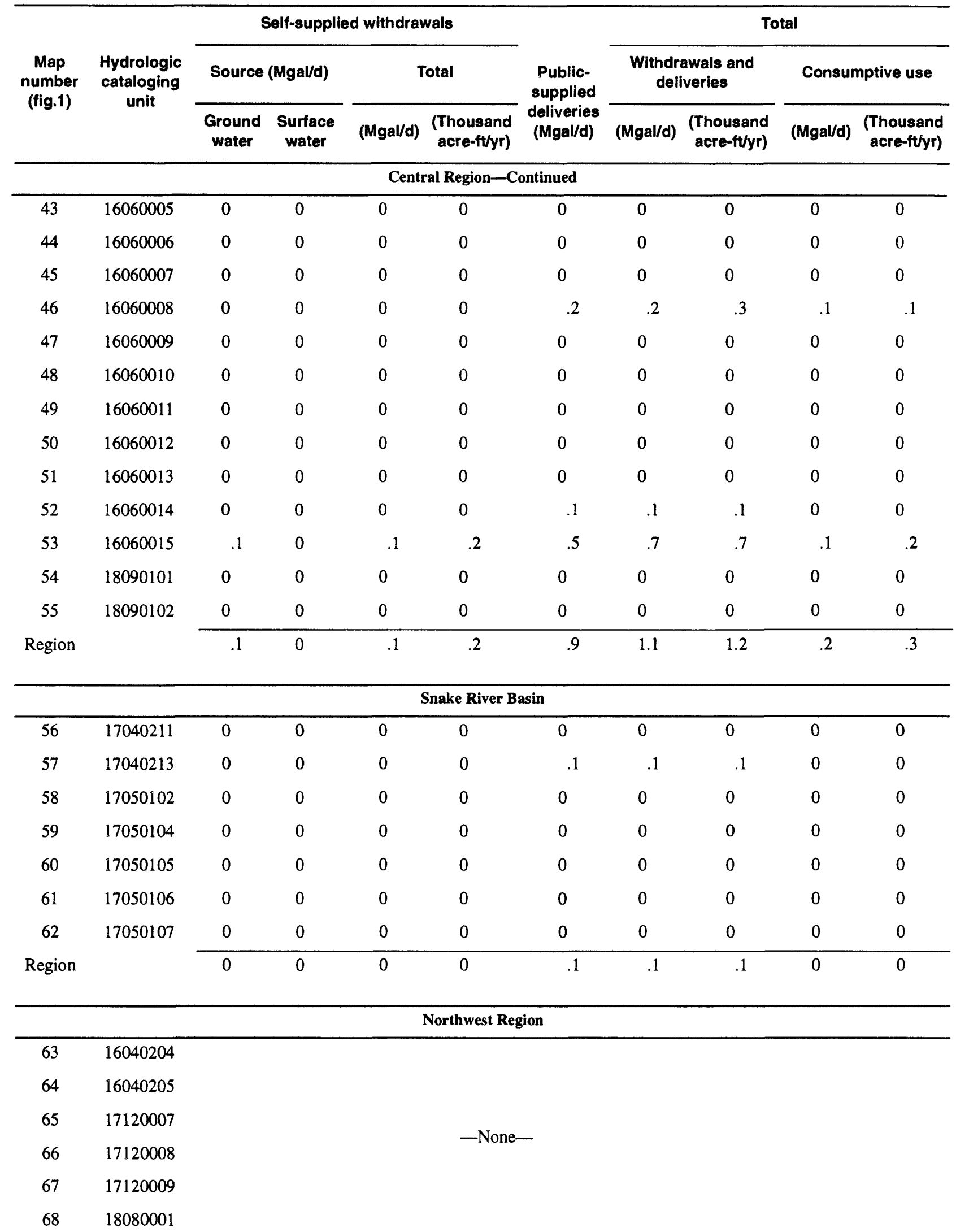


Table 10. Commerical freshwater use in Nevada, by hydrologic cataloging unit, 1985-Continued

\begin{tabular}{|c|c|c|c|c|c|c|c|c|c|c|}
\hline \multirow{3}{*}{$\begin{array}{c}\text { Map } \\
\text { number } \\
\text { (fig.1) }\end{array}$} & \multirow{3}{*}{$\begin{array}{c}\text { Hydrologic } \\
\text { cataloging } \\
\text { unit }\end{array}$} & \multicolumn{4}{|c|}{ Self-supplied withdrawals } & \multirow{3}{*}{$\begin{array}{l}\text { Public- } \\
\text { supplied } \\
\text { deliveries } \\
\text { (Mgal/d) }\end{array}$} & \multicolumn{4}{|c|}{ Total } \\
\hline & & \multicolumn{2}{|c|}{ Source (Mgal/d) } & \multicolumn{2}{|c|}{ Total } & & \multicolumn{2}{|c|}{$\begin{array}{c}\text { Withdrawals and } \\
\text { deliveries }\end{array}$} & \multicolumn{2}{|c|}{ Consumptive use } \\
\hline & & $\begin{array}{l}\text { Ground } \\
\text { water }\end{array}$ & $\begin{array}{c}\text { Surface } \\
\text { water }\end{array}$ & (Mgal/d) & $\begin{array}{l}\text { (Thousand } \\
\text { acre-ftyr) }\end{array}$ & & (Mgal/d) & $\begin{array}{l}\text { (Thousand } \\
\text { acre-ft/yr) }\end{array}$ & (Mgal/d) & $\begin{array}{r}\text { (Thousand } \\
\text { acre-ft/yr) }\end{array}$ \\
\hline \multicolumn{11}{|c|}{ Western Region } \\
\hline 69 & 18080003 & 0 & 0 & 0 & 0 & .1 & .1 & .1 & 0 & 0 \\
\hline \multicolumn{11}{|c|}{ Death Valley Basin } \\
\hline 70 & 18090201 & 0 & 0 & 0 & 0 & 0 & 0 & 0 & 0 & 0 \\
\hline 71 & 18090202 & .1 & 0 & .1 & .1 & 0 & .1 & .1 & 0 & 0 \\
\hline 72 & 18090203 & 0 & 0 & 0 & 0 & 0 & 0 & 0 & 0 & 0 \\
\hline Region & & .1 & 0 & .1 & .1 & 0 & .1 & .1 & 0 & 0 \\
\hline STATE & & 7.0 & .4 & 7.4 & 8.3 & 54 & 61 & 69 & 12 & 14 \\
\hline
\end{tabular}


Table 11. Commercial freshwater use in Nevada, by county 1985

[All values rounded; State values rounded from summation of unrounded values. Abbreviations: acre-ft/yr, acre-feet per year; Mgal/d, million gallons per day]

\begin{tabular}{|c|c|c|c|c|c|c|c|c|c|}
\hline \multirow{3}{*}{ County } & \multicolumn{4}{|c|}{ Self-supplied withdrawals } & \multirow{3}{*}{$\begin{array}{l}\text { Public-supplied } \\
\text { deliveries } \\
\text { (Mgal/d) }\end{array}$} & \multicolumn{4}{|c|}{ Total } \\
\hline & \multicolumn{2}{|c|}{ Source (Mgal/d) } & \multicolumn{2}{|c|}{ Total } & & \multicolumn{2}{|c|}{ Withdrawals and deliveries } & \multicolumn{2}{|c|}{ Consumptive use } \\
\hline & $\begin{array}{l}\text { Ground } \\
\text { water }\end{array}$ & $\begin{array}{l}\text { Surface } \\
\text { water }\end{array}$ & Mgal/d & $\begin{array}{l}\text { Thousand } \\
\text { acre-ft/yr }\end{array}$ & & Mgal/d & $\begin{array}{l}\text { Thousand } \\
\text { acre-ft/yr }\end{array}$ & Mgal/d & $\begin{array}{l}\text { Thousand } \\
\text { acre-ft/yr }\end{array}$ \\
\hline Carson City & 0 & 0 & 0 & 0 & 1.0 & 1.0 & 1.1 & 0.2 & 0.2 \\
\hline Churchill & 0 & 0 & 0 & 0 & .3 & .3 & .4 & .1 & .1 \\
\hline Clark & 5.7 & .4 & 6.0 & 6.8 & 38 & 44 & 49 & 8.8 & 9.8 \\
\hline Douglas & .1 & 0 & .1 & .1 & .5 & .6 & .7 & .1 & .2 \\
\hline Elko & .4 & 0 & .4 & .4 & 1.4 & 1.7 & 2.0 & .4 & .4 \\
\hline Esmeralda & 0 & 0 & 0 & 0 & 0 & 0 & 0 & 0 & 0 \\
\hline Eureka & 0 & 0 & 0 & 0 & 0 & 0 & 0 & 0 & 0 \\
\hline Humboldt & 0 & 0 & 0 & 0 & .1 & .1 & .1 & 0 & 0 \\
\hline Lander & 0 & 0 & 0 & 0 & .1 & .1 & .1 & 0 & 0 \\
\hline Lincoln & 0 & 0 & 0 & 0 & 0 & .1 & .1 & 0 & 0 \\
\hline Lyon & .1 & 0 & .1 & .1 & .2 & .3 & .3 & .1 & .1 \\
\hline Mineral & 0 & 0 & 0 & 0 & .2 & .3 & .3 & .1 & .1 \\
\hline Nye & .1 & 0 & .1 & .1 & .2 & .3 & .4 & .1 & .1 \\
\hline Pershing & 0 & 0 & 0 & 0 & .2 & .2 & .2 & 0 & 0 \\
\hline Storey & 0 & 0 & 0 & 0 & .1 & .1 & .1 & 0 & 0 \\
\hline Washoe & .5 & 0 & .5 & .5 & 12 & 12 & 14 & 2.4 & 2.7 \\
\hline White Pine & 0 & 0 & 0 & 0 & .2 & .3 & .3 & .1 & .1 \\
\hline STATE & 7.0 & .4 & 7.4 & 8.3 & 54 & 61 & 69 & 12 & 14 \\
\hline
\end{tabular}




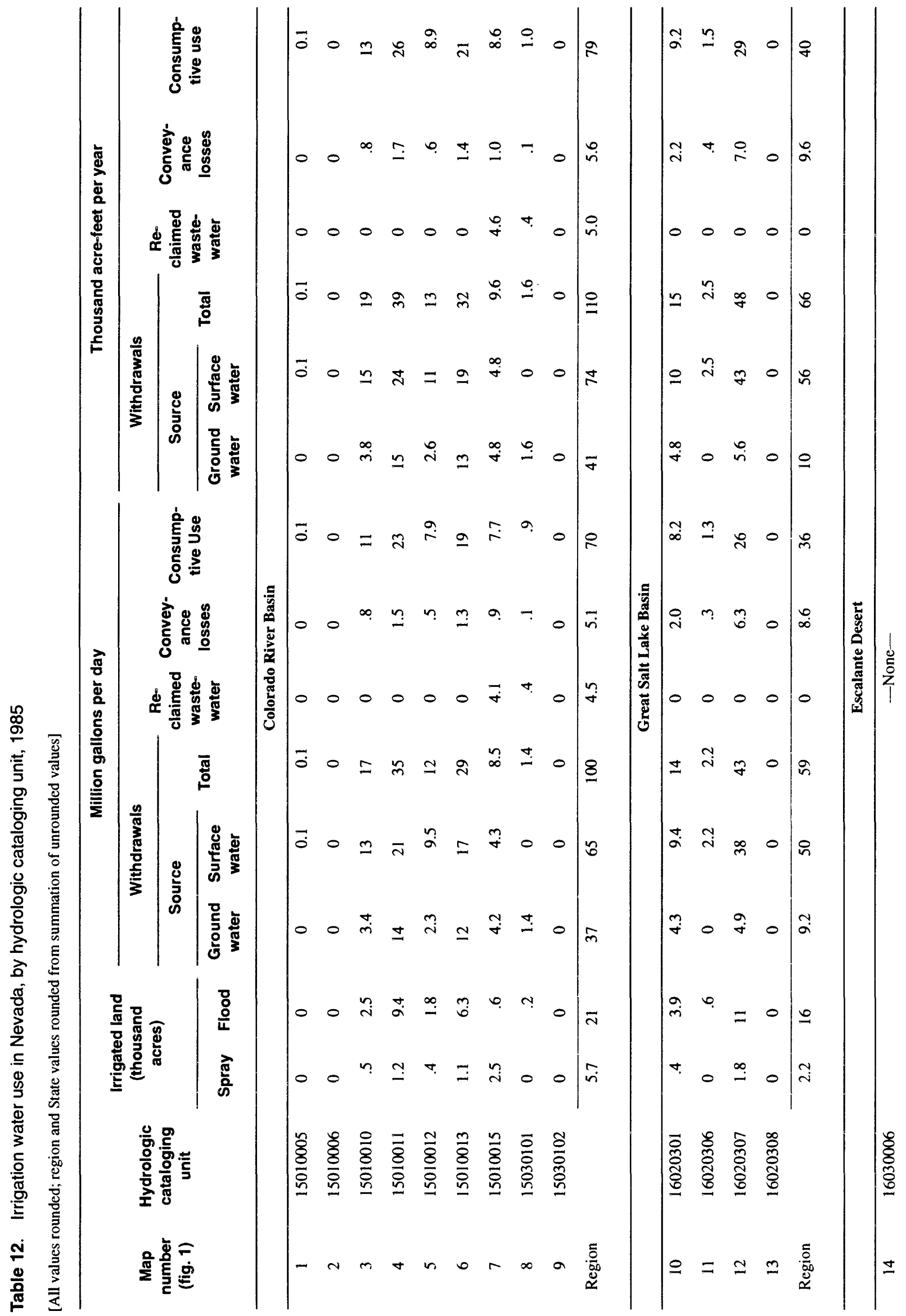




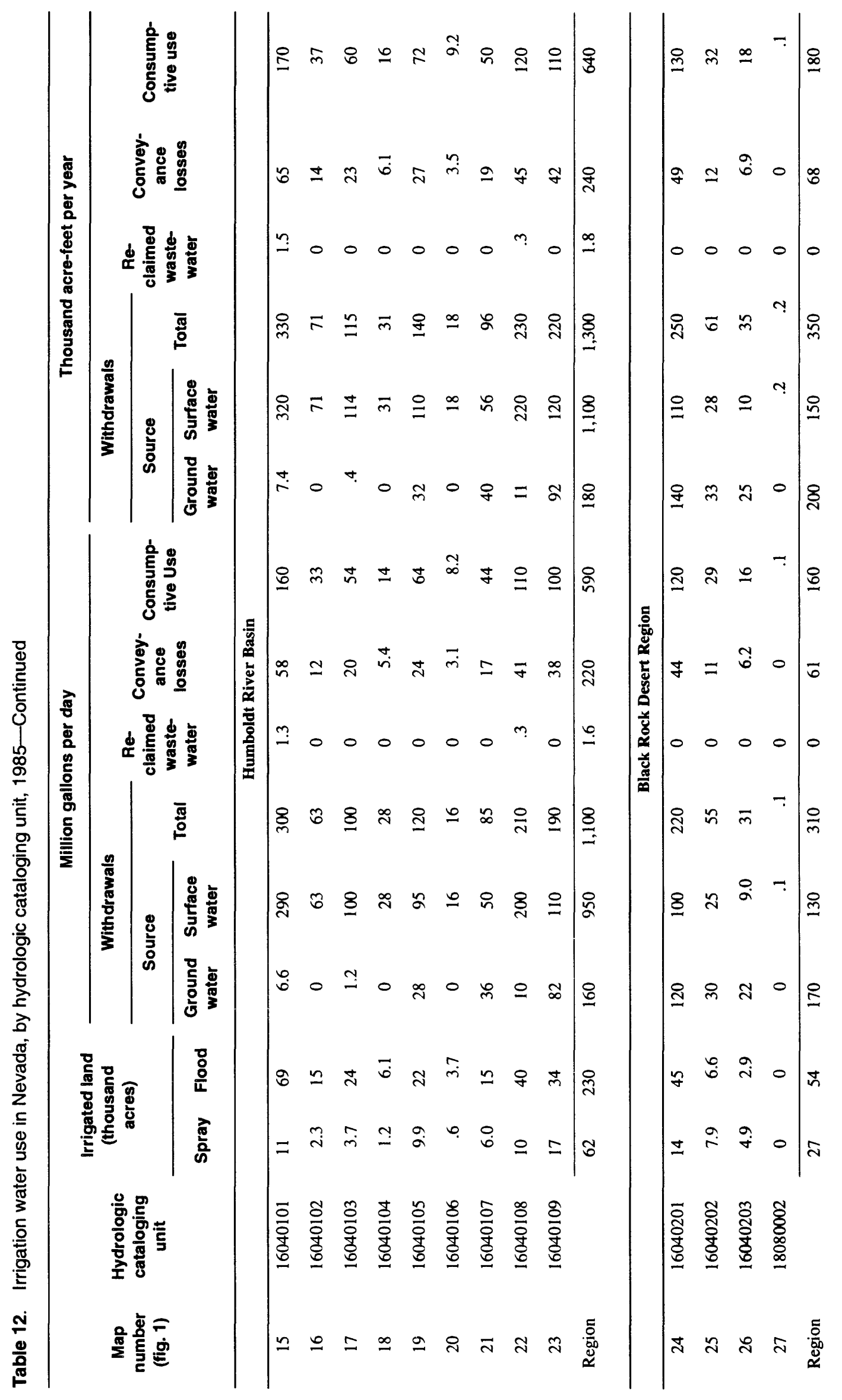




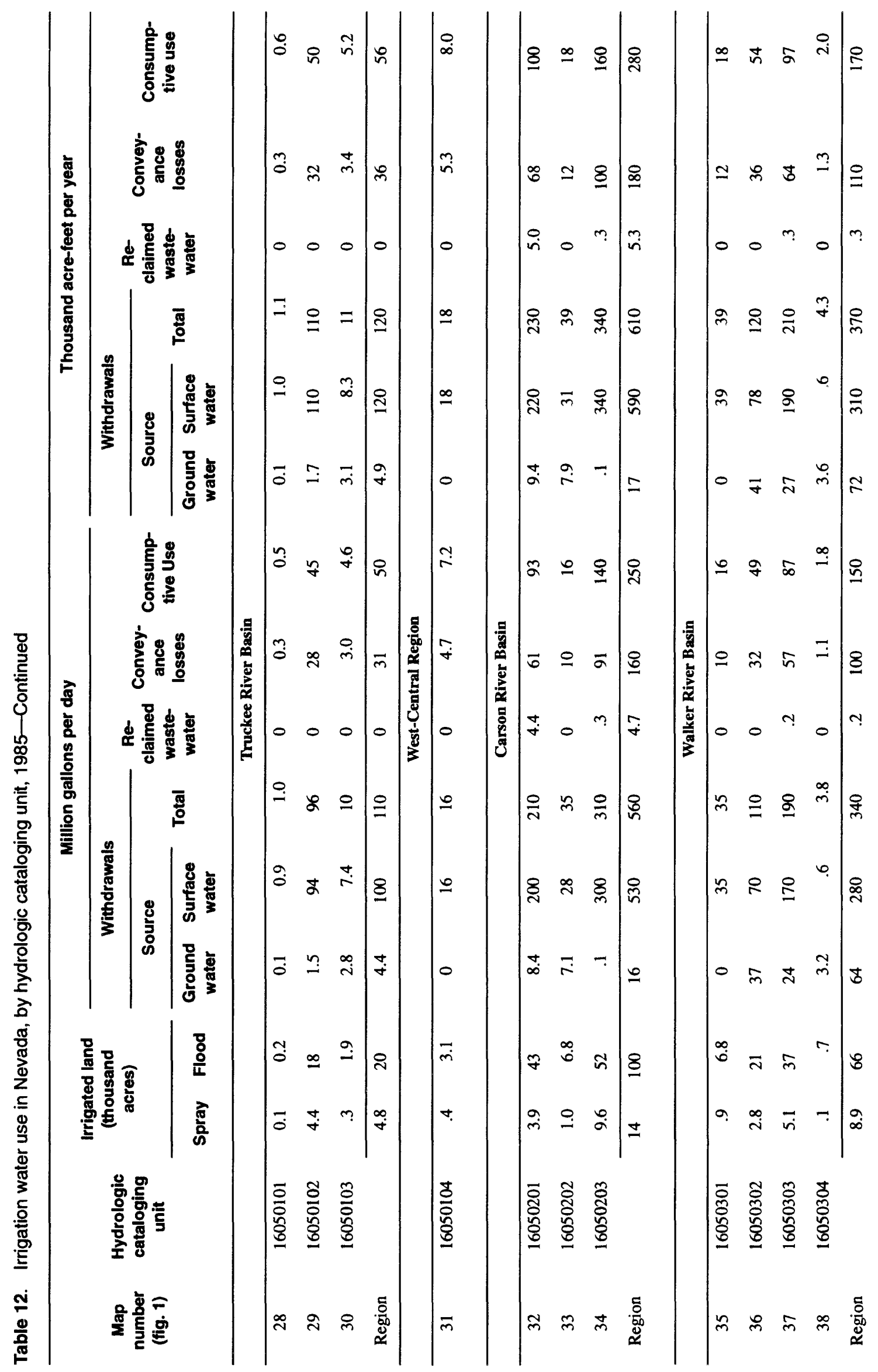




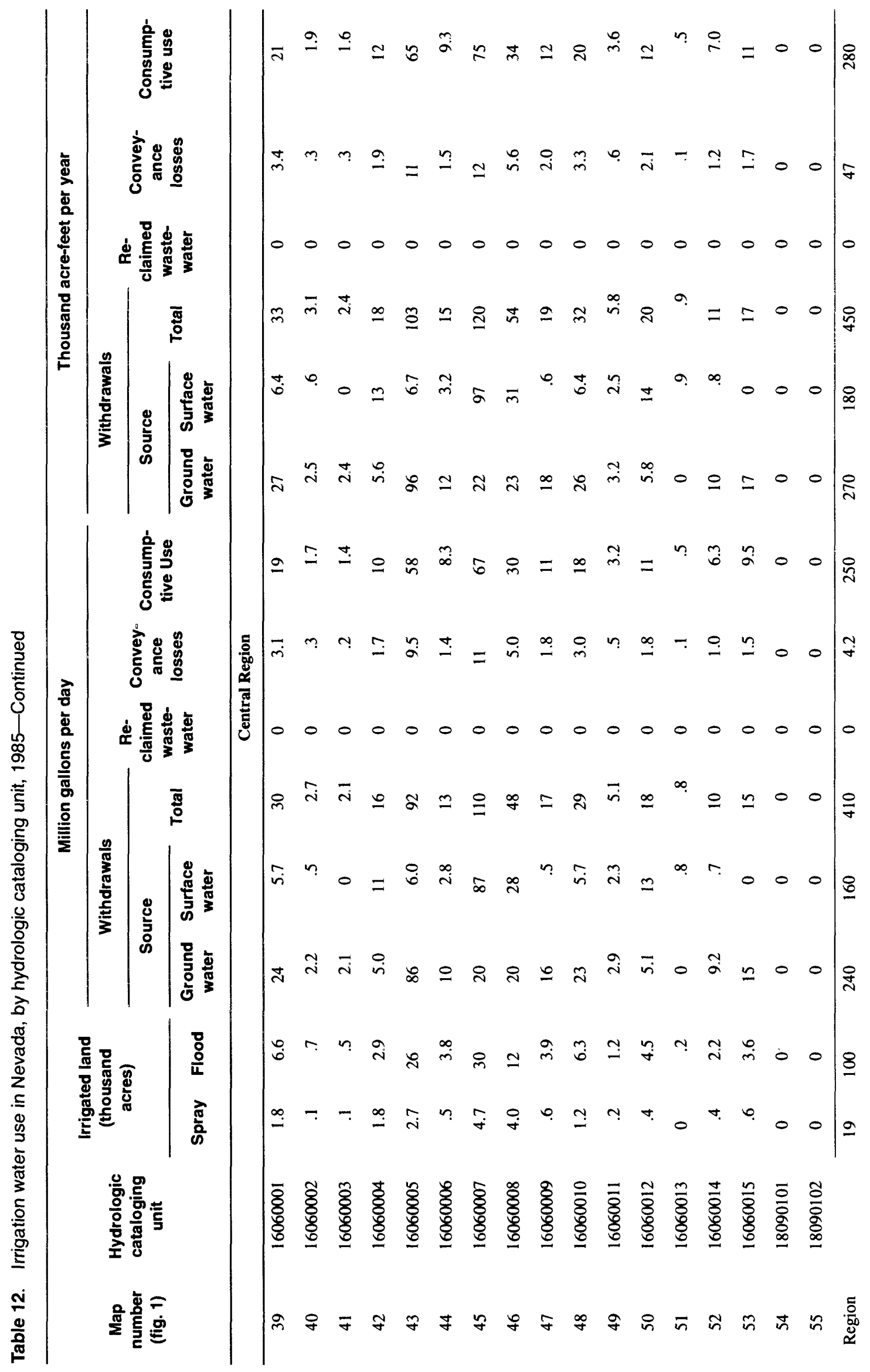




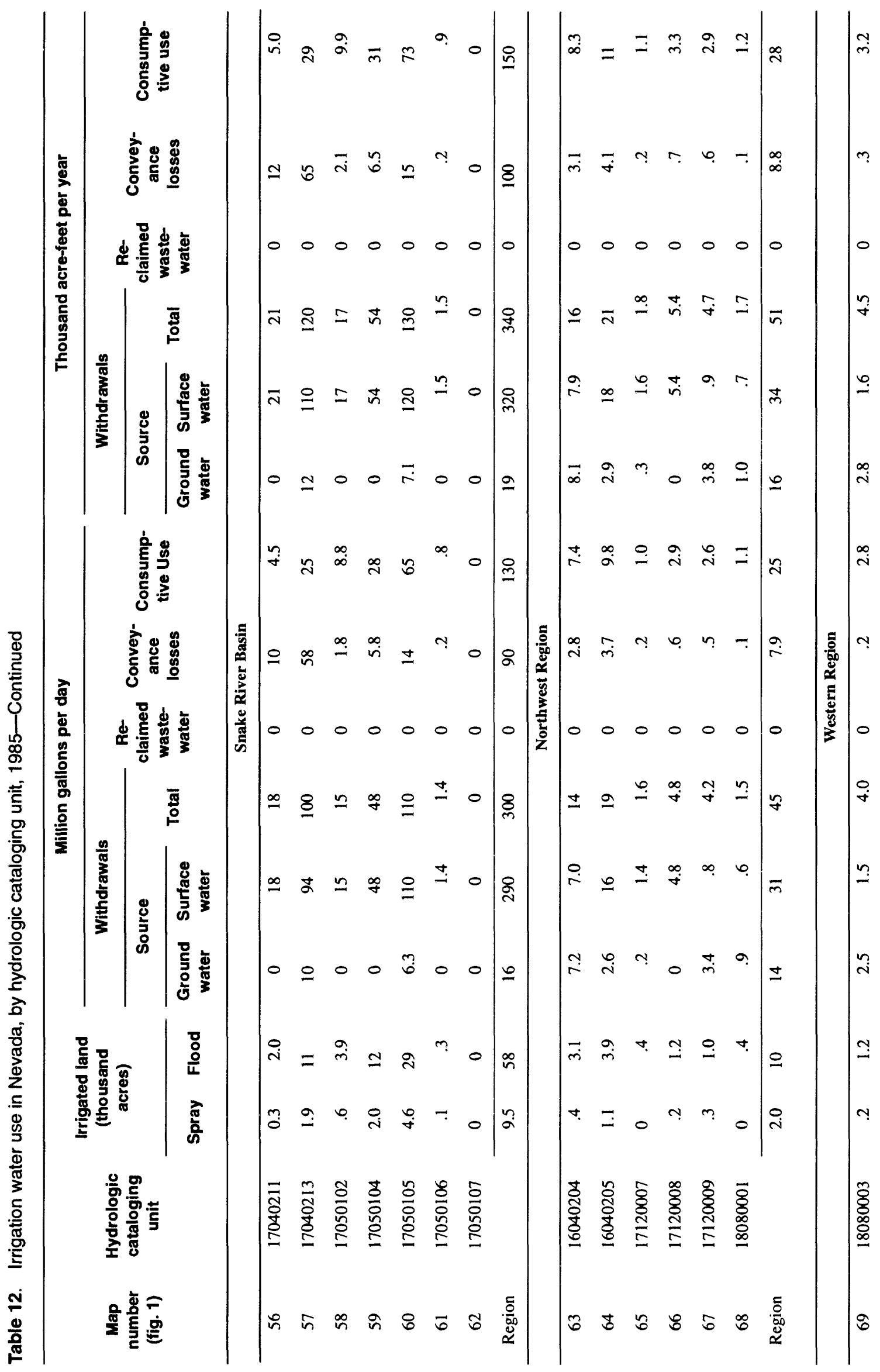




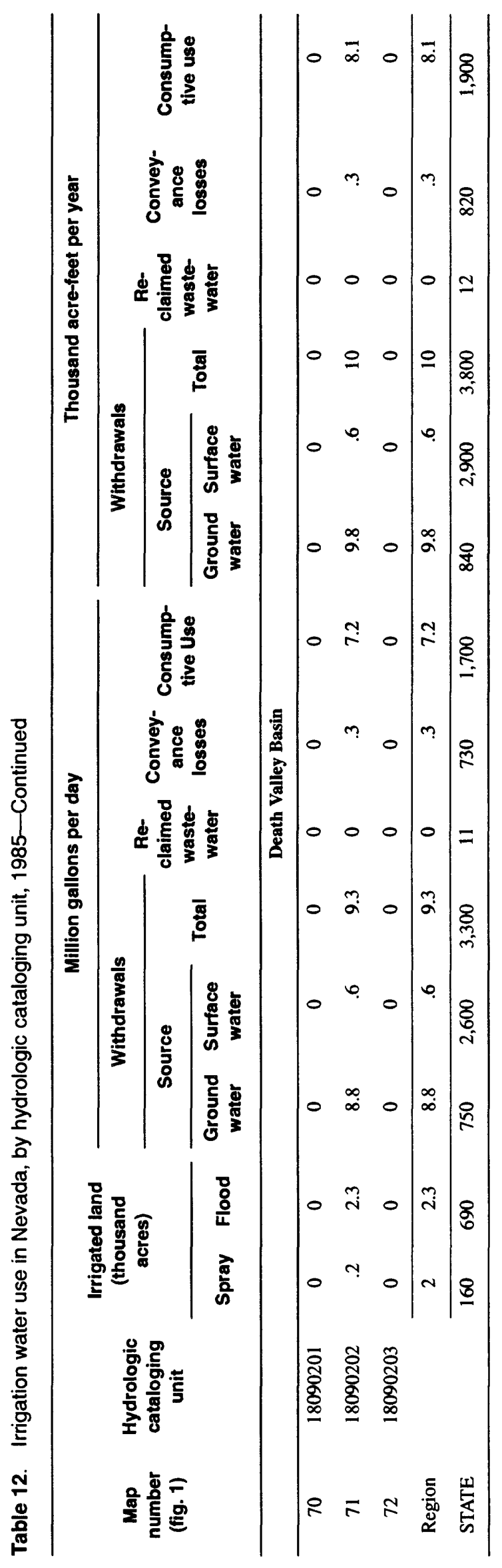




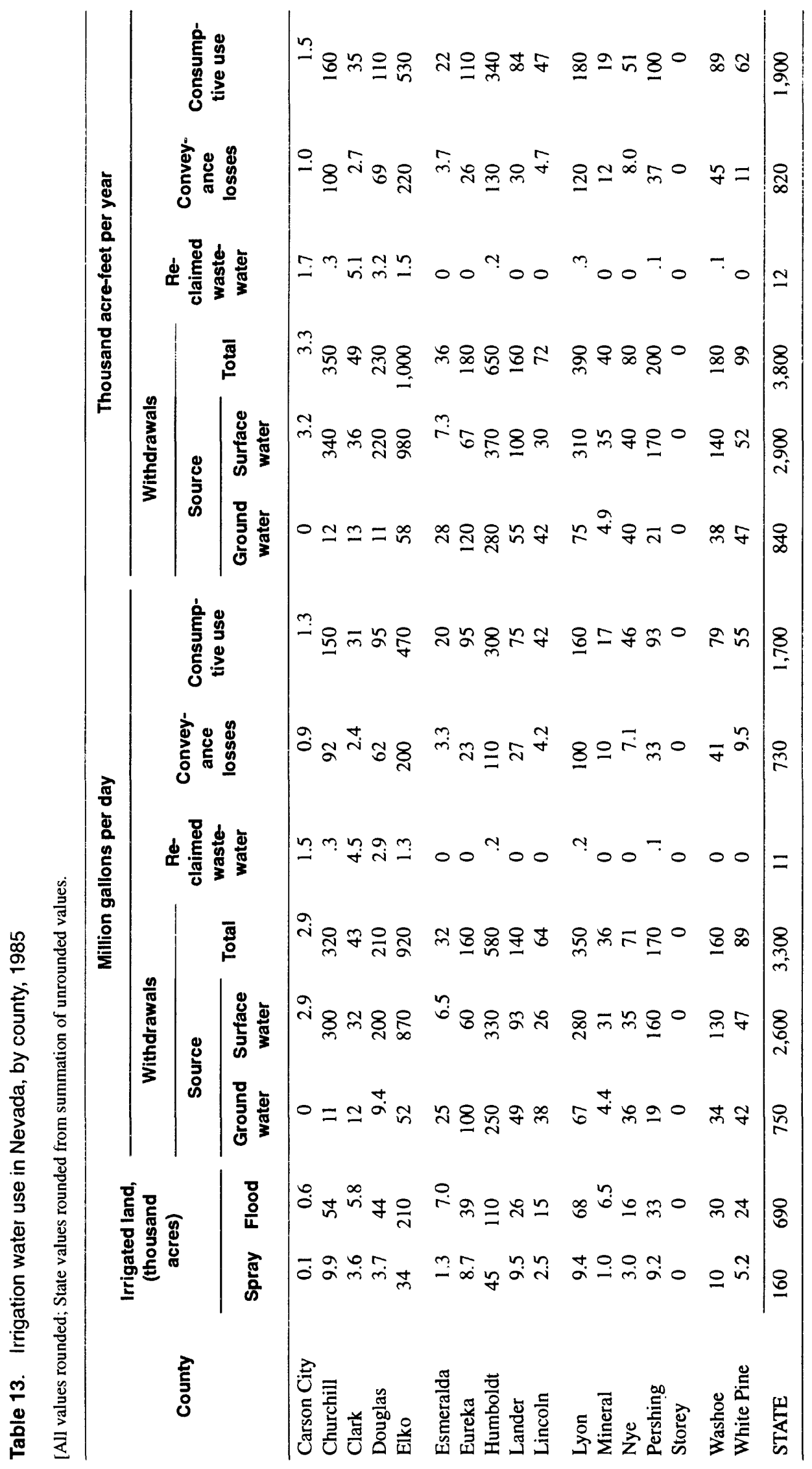


Table 14. Nonirrigation agriculture water use in Nevada, by hydrologic cataloging unit, 1985

[All values rounded; region and State values rounded from summation of unrounded values. Abbreviations: acre-ft/yr, acre-feet per year; Mgal/d, million gallons per day]

\begin{tabular}{|c|c|c|c|c|c|c|c|c|c|}
\hline \multirow{5}{*}{$\begin{array}{c}\text { Map } \\
\text { number } \\
\text { (fig. 1) }\end{array}$} & \multirow{5}{*}{$\begin{array}{c}\text { Hydrologic } \\
\text { cataloging } \\
\text { unit }\end{array}$} & \multicolumn{6}{|c|}{ Withdrawals } & \multirow{2}{*}{\multicolumn{2}{|c|}{ Consumptive use }} \\
\hline & & \multicolumn{4}{|c|}{ Type of use } & \multirow{2}{*}{\multicolumn{2}{|c|}{ Total }} & & \\
\hline & & \multicolumn{2}{|c|}{ Livestock } & \multicolumn{2}{|c|}{ Fisheries } & & & & \\
\hline & & \multicolumn{2}{|c|}{ Source (Mgal/d) } & \multicolumn{2}{|c|}{ Source (Mgal/d) } & \multirow[b]{2}{*}{ Mgal/d } & \multirow{2}{*}{$\begin{array}{l}\text { Thousand } \\
\text { acre-ft/yr }\end{array}$} & \multirow[b]{2}{*}{ Mgal/d } & \multirow{2}{*}{$\begin{array}{l}\text { Thousand } \\
\text { acre-ft/yr }\end{array}$} \\
\hline & & $\begin{array}{l}\text { Ground } \\
\text { water }\end{array}$ & $\begin{array}{l}\text { Surface } \\
\text { water }\end{array}$ & $\begin{array}{l}\text { Ground } \\
\text { water }\end{array}$ & $\begin{array}{c}\text { Surface } \\
\text { water }\end{array}$ & & & & \\
\hline \multicolumn{10}{|c|}{ Colorado River Basin } \\
\hline 1 & 15010005 & 0 & 0 & 0 & 3.7 & 3.7 & 4.1 & 0 & 0 \\
\hline 2 & 15010006 & 0 & 0 & 0 & 0 & 0 & 0 & 0 & 0 \\
\hline 3 & 15010010 & 0 & 0 & 0 & 0 & .1 & .1 & 0 & 0 \\
\hline 4 & 15010011 & .1 & 0 & 0 & 0 & .2 & .2 & .1 & .2 \\
\hline 5 & 15010012 & 0 & 0 & 0 & 0 & 0 & 0 & 0 & 0 \\
\hline 6 & 15010013 & .1 & 0 & 0 & 0 & .1 & .1 & .1 & .1 \\
\hline 7 & 15010015 & .4 & .3 & 0 & 0 & .6 & .7 & .4 & .5 \\
\hline 8 & 15030101 & 0 & 0 & 0 & 0 & 0 & 0 & 0 & 0 \\
\hline 9 & 15030102 & 0 & 0 & 0 & 0 & 0 & 0 & 0 & 0 \\
\hline Region & & .5 & .3 & 0 & 3.7 & 4.7 & 5.2 & .6 & .8 \\
\hline \multicolumn{10}{|c|}{ Great Salt Lake Basin } \\
\hline 10 & 16020301 & 0 & 0 & 0 & 2.6 & 2.6 & 3.0 & .1 & .1 \\
\hline 11 & 16020306 & 0 & 0 & 0 & 0 & 0 & 0 & 0 & 0 \\
\hline 12 & 16020307 & .1 & .1 & 0 & 0 & .2 & .2 & .1 & .1 \\
\hline 13 & 16020308 & 0 & 0 & 0 & 0 & 0 & 0 & 0 & 0 \\
\hline Region & & .1 & .1 & 0 & 2.6 & 2.8 & 3.2 & .2 & .2 \\
\hline \multicolumn{10}{|c|}{ Escalante Desert } \\
\hline 14 & 16030006 & & & & & & & & \\
\hline \multicolumn{10}{|c|}{$\frac{\text {-None- }}{\text { Humboldt River Basin }}$} \\
\hline 15 & 16040101 & .4 & .5 & 0 & 0 & 0 & 1.0 & .5 & .6 \\
\hline 16 & 16040102 & .1 & .1 & 0 & 0 & .2 & .2 & .1 & .1 \\
\hline 17 & 16040103 & .2 & .2 & 0 & 0 & .3 & .4 & .2 & .2 \\
\hline 18 & 16040104 & 0 & 0 & 0 & 0 & .1 & .1 & .1 & .1 \\
\hline 19 & 16040105 & .2 & .2 & 0 & 0 & .4 & .4 & .2 & .3 \\
\hline 20 & 16040106 & 0 & 0 & 0 & 0 & .1 & .1 & 0 & 0 \\
\hline 21 & 16040107 & .1 & .1 & 0 & 0 & .2 & .3 & .1 & .2 \\
\hline 22 & 16040108 & .3 & .3 & 0 & 0 & .6 & .7 & .3 & .4 \\
\hline 23 & 16040109 & .3 & .3 & 0 & 0 & .6 & .7 & .4 & .4 \\
\hline Region & & 1.6 & 1.7 & 0 & 0 & 3.4 & 3.9 & 1.9 & 2.3 \\
\hline
\end{tabular}


Table 14. Nonirrigation agriculture water use in Nevada, by hydrologic cataloging unit, 1985—Continued

\begin{tabular}{|c|c|c|c|c|c|c|c|c|c|}
\hline \multirow{5}{*}{$\begin{array}{c}\text { Map } \\
\text { number } \\
\text { (fig. 1) }\end{array}$} & \multirow{5}{*}{$\begin{array}{c}\text { Hydrologic } \\
\text { cataloging } \\
\text { unit }\end{array}$} & \multicolumn{6}{|c|}{ Withdrawals } & \multirow{2}{*}{\multicolumn{2}{|c|}{ Consumptive use }} \\
\hline & & \multicolumn{4}{|c|}{ Type of use } & \multirow{2}{*}{\multicolumn{2}{|c|}{ Total }} & & \\
\hline & & \multicolumn{2}{|c|}{ Livestock } & \multicolumn{2}{|c|}{ Fisheries } & & & & \\
\hline & & Source ( & (Mgal/d) & Source ( & (Mgal/d) & \multirow[b]{2}{*}{ Mgal/d } & \multirow{2}{*}{$\begin{array}{l}\text { Thousand } \\
\text { acre-ft/yr }\end{array}$} & \multirow[b]{2}{*}{ Mgal/d } & \multirow{2}{*}{$\begin{array}{l}\text { Thousand } \\
\text { acre-ft/yr }\end{array}$} \\
\hline & & $\begin{array}{l}\text { Ground } \\
\text { water }\end{array}$ & $\begin{array}{c}\text { Surface } \\
\text { water }\end{array}$ & $\begin{array}{l}\text { Ground } \\
\text { water }\end{array}$ & $\begin{array}{l}\text { Surface } \\
\text { water }\end{array}$ & & & & \\
\hline \multicolumn{10}{|c|}{ Black Rock Desert Region } \\
\hline 24 & 16040201 & 0.3 & 0.4 & 0 & 0 & 0.7 & 0.8 & 0.4 & 0.4 \\
\hline 25 & 16040202 & .1 & .1 & 0 & 0 & .2 & .2 & .1 & .1 \\
\hline 26 & 16040203 & 0 & .1 & 0 & 0 & .1 & .1 & .1 & .1 \\
\hline 27 & 18080002 & 0 & 0 & 0 & 0 & 0 & 0 & 0 & 0 \\
\hline Region & & .4 & .6 & 0 & 0 & 1.0 & 1.1 & .6 & .6 \\
\hline \multicolumn{10}{|c|}{ Truckee River Basin } \\
\hline 28 & 16050101 & 0 & 0 & 0 & 0 & 0 & 0 & 0 & 0 \\
\hline 29 & 16050102 & 0 & .3 & .6 & 0 & .9 & 1.0 & .2 & .2 \\
\hline 30 & 16050103 & 0 & 0 & .4 & 1.9 & 2.4 & 2.6 & 0 & 0 \\
\hline Region & & 0 & .3 & 1.0 & 1.9 & 3.3 & 3.6 & .2 & .2 \\
\hline \multicolumn{10}{|c|}{ West-Central Region } \\
\hline 31 & 16050104 & 0 & .1 & 0 & 0 & .1 & .1 & 0 & 0 \\
\hline \multicolumn{10}{|c|}{ Carson River Basin } \\
\hline 32 & 16050201 & .1 & .6 & .2 & 0 & .9 & 1.0 & .3 & .3 \\
\hline 33 & 16050202 & 0 & .1 & 0 & 0 & .1 & .1 & 0 & 0 \\
\hline 34 & 16050203 & .1 & .8 & 0 & 0 & .9 & 1.0 & .3 & .4 \\
\hline Region & & .2 & 1.5 & .2 & 0 & 1.9 & 2.1 & .6 & .7 \\
\hline \multicolumn{10}{|c|}{ Walker River Basin } \\
\hline 35 & 16050301 & 0 & .1 & 0 & 0 & .1 & .1 & 0 & 0 \\
\hline 36 & 16050302 & .1 & .3 & 0 & .3 & .7 & .8 & .1 & .2 \\
\hline 37 & 16050303 & .1 & .5 & 0 & 0 & .6 & .7 & .2 & .3 \\
\hline 38 & 16050304 & 0 & 0 & 0 & 0 & 0 & 0 & 0 & 0 \\
\hline Region & & .2 & .9 & 0 & .3 & 1.4 & 1.6 & .3 & .4 \\
\hline
\end{tabular}


Table 14. Nonirrigation agriculture water use in Nevada, by hydrologic cataloging unit, 1985—Continued

\begin{tabular}{|c|c|c|c|c|c|c|c|c|c|}
\hline \multirow{5}{*}{$\begin{array}{c}\text { Map } \\
\text { number } \\
\text { (fig. 1) }\end{array}$} & \multirow{5}{*}{$\begin{array}{c}\text { Hydrologic } \\
\text { cataloging } \\
\text { unit }\end{array}$} & \multicolumn{6}{|c|}{ Withdrawals } & \multirow{2}{*}{\multicolumn{2}{|c|}{ Consumptive use }} \\
\hline & & \multicolumn{4}{|c|}{ Type of use } & \multirow{2}{*}{\multicolumn{2}{|c|}{ Total }} & & \\
\hline & & \multicolumn{2}{|c|}{ Livestock } & \multicolumn{2}{|c|}{ Fisheries } & & & & \\
\hline & & \multicolumn{2}{|c|}{ Source (Mgal/d) } & \multicolumn{2}{|c|}{ Source (Mgal/d) } & \multirow[b]{2}{*}{ Mgal/d } & \multirow{2}{*}{$\begin{array}{l}\text { Thousand } \\
\text { acre-ft/yr }\end{array}$} & \multirow[b]{2}{*}{ Mgal/d } & \multirow{2}{*}{$\begin{array}{l}\text { Thousano } \\
\text { acre-ft/yr }\end{array}$} \\
\hline & & $\begin{array}{l}\text { Ground } \\
\text { water }\end{array}$ & $\begin{array}{c}\text { Surface } \\
\text { water }\end{array}$ & $\begin{array}{c}\text { Ground } \\
\text { water }\end{array}$ & $\begin{array}{c}\text { Surface } \\
\text { water }\end{array}$ & & & & \\
\hline \multicolumn{10}{|c|}{ Central Region } \\
\hline 39 & 16060001 & 0.1 & 0.1 & 0 & 0 & 0.1 & 0.2 & 0.1 & 0.1 \\
\hline 40 & 16060002 & 0 & 0 & 0 & 0 & 0 & 0 & 0 & 0 \\
\hline 41 & 16060003 & 0 & 0 & 0 & 0 & 0 & 0 & 0 & 0 \\
\hline 42 & 16060004 & 0 & .1 & 0 & 0 & .1 & .1 & .1 & .1 \\
\hline 43 & 16060005 & .2 & .2 & 0 & 0 & .4 & .5 & .3 & .3 \\
\hline 44 & 16060006 & 0 & 0 & 0 & 0 & .1 & .1 & 0 & 0 \\
\hline 45 & 16060007 & .3 & .2 & 0 & 4.5 & 5.0 & 5.6 & .5 & .6 \\
\hline 46 & 16060008 & .1 & .1 & 0 & 0 & .2 & .3 & .2 & .2 \\
\hline 47 & 16060009 & 0 & 0 & 0 & 0 & .1 & .1 & 0 & 0 \\
\hline 48 & 16060010 & .1 & .1 & 0 & 0 & .1 & .1 & .1 & .1 \\
\hline 49 & 16060011 & 0 & 0 & 0 & 0 & 0 & 0 & 0 & 0 \\
\hline 50 & 16060012 & 0 & 0 & 0 & 0 & .1 & .1 & .1 & .1 \\
\hline 51 & 16060013 & 0 & 0 & 0 & 0 & 0 & 0 & 0 & 0 \\
\hline 52 & 16060014 & 0 & 0 & 0 & 0 & .1 & .1 & 0 & 0 \\
\hline 53 & 16060015 & 0 & 0 & 0 & 0 & .1 & .1 & 0 & 0 \\
\hline 54 & 18090101 & 0 & 0 & 0 & 0 & 0 & 0 & 0 & 0 \\
\hline 55 & 18090102 & 0 & 0 & 0 & 0 & 0 & 0 & 0 & 0 \\
\hline Region & & .8 & .8 & 0 & 4.5 & 6.4 & 7.3 & 1.4 & 1.5 \\
\hline \multicolumn{10}{|c|}{ Snake River Basin } \\
\hline 56 & 17040211 & 0 & 0 & 0 & 0 & 0 & 0 & 0 & 0 \\
\hline 57 & 17040213 & .1 & .1 & 0 & 0 & .2 & .2 & .1 & .1 \\
\hline 58 & 17050102 & 0 & 0 & 0 & 0 & .1 & .1 & 0 & 0 \\
\hline 59 & 17050104 & .1 & .1 & 0 & 0 & .2 & .2 & .1 & .1 \\
\hline 60 & 17050105 & .1 & .3 & 0 & 0 & .4 & .5 & .2 & .3 \\
\hline 61 & 17050106 & 0 & 0 & 0 & 0 & 0 & 0 & 0 & 0 \\
\hline 62 & 17050107 & 0 & 0 & 0 & 0 & 0 & 0 & 0 & 0 \\
\hline Region & & .3 & .5 & 0 & 0 & .9 & 1.0 & .4 & .5 \\
\hline
\end{tabular}


Table 14. Nonirrigation agriculture water use in Nevada, by hydrologic cataloging unit, 1985-Continued

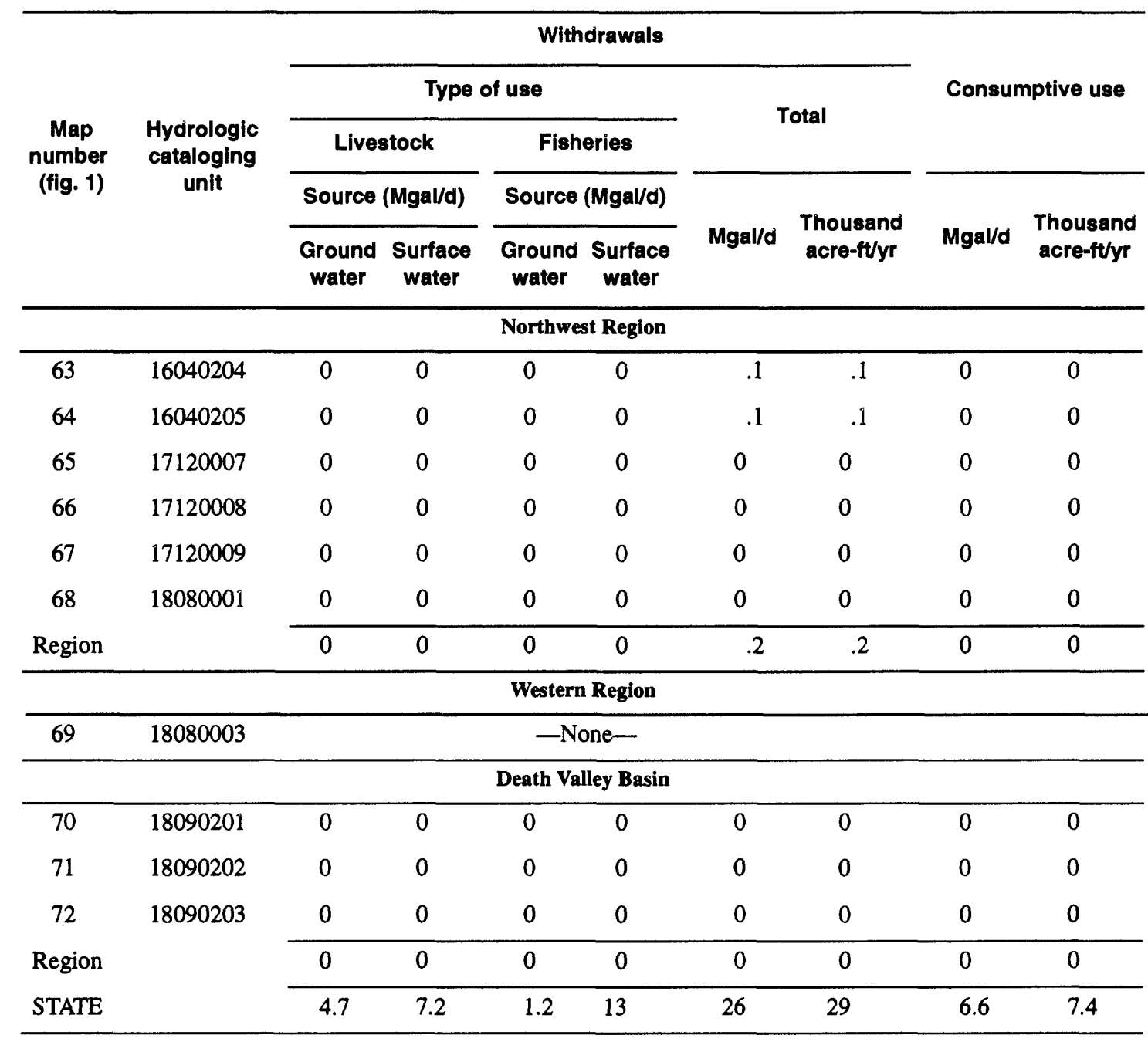


Table 15. Nonirrigation agriculture water use in Nevada, by county, 1985

[All values rounded; State values were rounded from summation of unrounded values. Abbreviations: acre-ft/yr, acre-feet per year; Mgal/d, million gallons per day]

\begin{tabular}{|c|c|c|c|c|c|c|c|c|}
\hline \multirow{5}{*}{ County } & \multicolumn{6}{|c|}{ Withdrawals } & \multirow{2}{*}{\multicolumn{2}{|c|}{ Consumptive use }} \\
\hline & \multicolumn{4}{|c|}{ Type of use } & \multirow{2}{*}{\multicolumn{2}{|c|}{ Total }} & & \\
\hline & \multicolumn{2}{|c|}{ Livestock } & \multicolumn{2}{|c|}{ Fisheries } & & & & \\
\hline & \multicolumn{2}{|c|}{ Source (Mgal/d) } & \multicolumn{2}{|c|}{ Source (Mgal/d) } & \multirow[b]{2}{*}{ Mgal/d } & \multirow{2}{*}{$\begin{array}{l}\text { Thousand } \\
\text { acre-ft/yr }\end{array}$} & \multirow[b]{2}{*}{ Mgal/d } & \multirow{2}{*}{$\begin{array}{l}\text { Thousand } \\
\text { acre-ft/yr }\end{array}$} \\
\hline & $\begin{array}{l}\text { Ground } \\
\text { water }\end{array}$ & $\begin{array}{c}\text { Surface } \\
\text { water }\end{array}$ & $\begin{array}{l}\text { Ground } \\
\text { water }\end{array}$ & $\begin{array}{c}\text { Surface } \\
\text { water }\end{array}$ & & & & \\
\hline Carson City & 0 & 0 & 0 & 0 & 0.1 & 0.1 & 0 & 0 \\
\hline Churchill & .5 & .7 & 0 & 0 & 1.2 & 1.3 & .6 & .7 \\
\hline Clark & .6 & .2 & 0 & 3.7 & 4.4 & 5.0 & .6 & .7 \\
\hline Douglas & 0 & .4 & .2 & 0 & 6 & .7 & .2 & .2 \\
\hline Elko & 1.3 & 2.0 & 0 & 4.5 & 7.8 & 8.7 & 1.9 & 2.2 \\
\hline Esmeralda & .2 & 0 & 0 & 0 & .2 & .2 & .2 & .2 \\
\hline Eureka & .2 & .3 & 0 & 0 & .5 & .6 & .3 & .3 \\
\hline Humboldt & .4 & .8 & 0 & 0 & 1.2 & 1.4 & .6 & .6 \\
\hline Lander & .2 & .3 & 0 & 0 & .5 & .6 & .3 & .3 \\
\hline Lincoln & .2 & .2 & 0 & 0 & .4 & .4 & .2 & .2 \\
\hline Lyon & .2 & .8 & 0 & .3 & 1.2 & 1.4 & .4 & .4 \\
\hline Mineral & .1 & 0 & 0 & 0 & .1 & .1 & .1 & .1 \\
\hline Nye & .2 & .3 & 0 & 0 & .5 & .5 & .3 & .3 \\
\hline Pershing & .1 & .4 & 0 & 0 & .5 & .5 & .2 & .2 \\
\hline Storey & 0 & 0 & 0 & 0 & 0 & 0 & 0 & 0 \\
\hline Washoe & .2 & .5 & 1.0 & 1.9 & 3.6 & 4.1 & .4 & .4 \\
\hline White Pine & .3 & .3 & 0 & 2.6 & 3.2 & 3.6 & .4 & .4 \\
\hline STATE & 4.7 & 7.2 & 1.2 & 13 & 26 & 29 & 6.6 & 7.4 \\
\hline
\end{tabular}


Table 16. Industrial water use in Nevada, by hydrologic cataloging unit, 1985

[All values rounded; region and State values rounded from summation of unrounded values. Abbreviations: acre-ft/yr, acre-feet per year; $\mathrm{Mgal} / \mathrm{d}$, million gallons per day]

\begin{tabular}{|c|c|c|c|c|c|c|c|c|c|c|}
\hline \multirow{3}{*}{$\begin{array}{c}\text { Map } \\
\text { number } \\
\text { (flg. 1) }\end{array}$} & \multirow{3}{*}{$\begin{array}{c}\text { Hydrologic } \\
\text { cataloging } \\
\text { unit }\end{array}$} & \multicolumn{4}{|c|}{ Self-supplied withdrawals } & \multirow{3}{*}{$\begin{array}{l}\text { Public- } \\
\text { supplied } \\
\text { deliv- } \\
\text { eries } \\
\text { (Mgal/d) }\end{array}$} & \multicolumn{4}{|c|}{ Total } \\
\hline & & \multicolumn{2}{|c|}{ Source (Mgal/d) } & \multicolumn{2}{|c|}{ Total } & & \multicolumn{2}{|c|}{$\begin{array}{l}\text { Withdrawal and } \\
\text { deliveries }\end{array}$} & \multicolumn{2}{|c|}{ Consumptive use } \\
\hline & & $\begin{array}{l}\text { Ground } \\
\text { water }\end{array}$ & $\begin{array}{l}\text { Surface } \\
\text { water }\end{array}$ & Mgal/d & $\begin{array}{l}\text { Thousand } \\
\text { acre-ft/yr }\end{array}$ & & Mgal/d & $\begin{array}{l}\text { Thousand } \\
\text { acre-ft/yr }\end{array}$ & Mgal/d & $\begin{array}{l}\text { Thousand } \\
\text { acre-ft/yr }\end{array}$ \\
\hline \multicolumn{11}{|c|}{ Colorado River $B \varepsilon$ sin } \\
\hline 1 & 15010005 & 0 & 0 & 0 & 0 & 0 & 0 & 0 & 0 & 0 \\
\hline 2 & 15010006 & 0 & 0 & 0 & 0 & 0 & 0 & 0 & 0 & 0 \\
\hline 3 & 15010010 & 0 & 0 & 0 & 0 & 0 & 0 & 0 & 0 & 0 \\
\hline 4 & 15010011 & 0 & 0 & 0 & 0 & 0 & 0 & 0 & 0 & 0 \\
\hline 5 & 15010012 & 0 & 0 & 0 & 0 & .1 & .1 & .1 & 0 & 0 \\
\hline 6 & 15010013 & 0 & 0 & 0 & 0 & 0 & 0 & 0 & 0 & 0 \\
\hline 7 & 15010015 & .6 & 7.4 & 8.1 & 9.0 & 1.4 & 9.4 & 10 & 1.8 & 2.0 \\
\hline 8 & 15030101 & 0 & 0 & 0 & 0 & 0 & 0 & 0 & 0 & 0 \\
\hline 9 & 15030102 & 0 & 0 & 0 & 0 & 0 & 0 & 0 & 0 & 0 \\
\hline Region & & .6 & 7.4 & 8.1 & 9.0 & 1.5 & 9.5 & 10 & 1.8 & 2.0 \\
\hline
\end{tabular}

\begin{tabular}{llc}
\hline & & Great Salt Lake Basin \\
\hline 10 & 16020301 & \\
11 & 16020306 & - None- \\
12 & 16020307 & \\
13 & 16020308 & \\
\hline
\end{tabular}

\begin{tabular}{ccccccccccc}
\hline \multicolumn{10}{c}{ Escalante Desert } \\
\hline 14 & 16030006 & \multicolumn{1}{c}{ Humboldt River Basin } \\
\hline 15 & 16040101 & 0 & 0 & 0 & 0 & 0 & 0 & 0 & 0 & 0 \\
16 & 16040102 & 0 & 0 & 0 & 0 & 0 & 0 & 0 & 0 & 0 \\
17 & 16040103 & 0 & 0 & 0 & 0 & 0 & 0 & 0 & 0 & 0 \\
18 & 16040104 & 0 & 0 & 0 & 0 & 0 & 0 & 0 & 0 & 0 \\
19 & 16040105 & .1 & .1 & .1 & .1 & .1 & .2 & .2 & 0 & 0 \\
20 & 16040106 & 0 & 0 & 0 & 0 & 0 & 0 & 0 & 0 & 0 \\
21 & 16040107 & 0 & 0 & 0 & 0 & 0 & 0 & 0 & 0 & 0 \\
22 & 16040108 & .1 & 0 & .1 & .1 & .1 & .1 & .1 & 0 & 0 \\
23 & 16040109 & 0 & 0 & 0 & 0 & 0 & 0 & 0 & 0 & 0 \\
\cline { 3 - 9 } Region & & .2 & .1 & .2 & .2 & .2 & .3 & .3 & 0 & 0
\end{tabular}


Table 16. Industrial water use in Nevada, by hydrologic cataloging unit, 1985—Continued

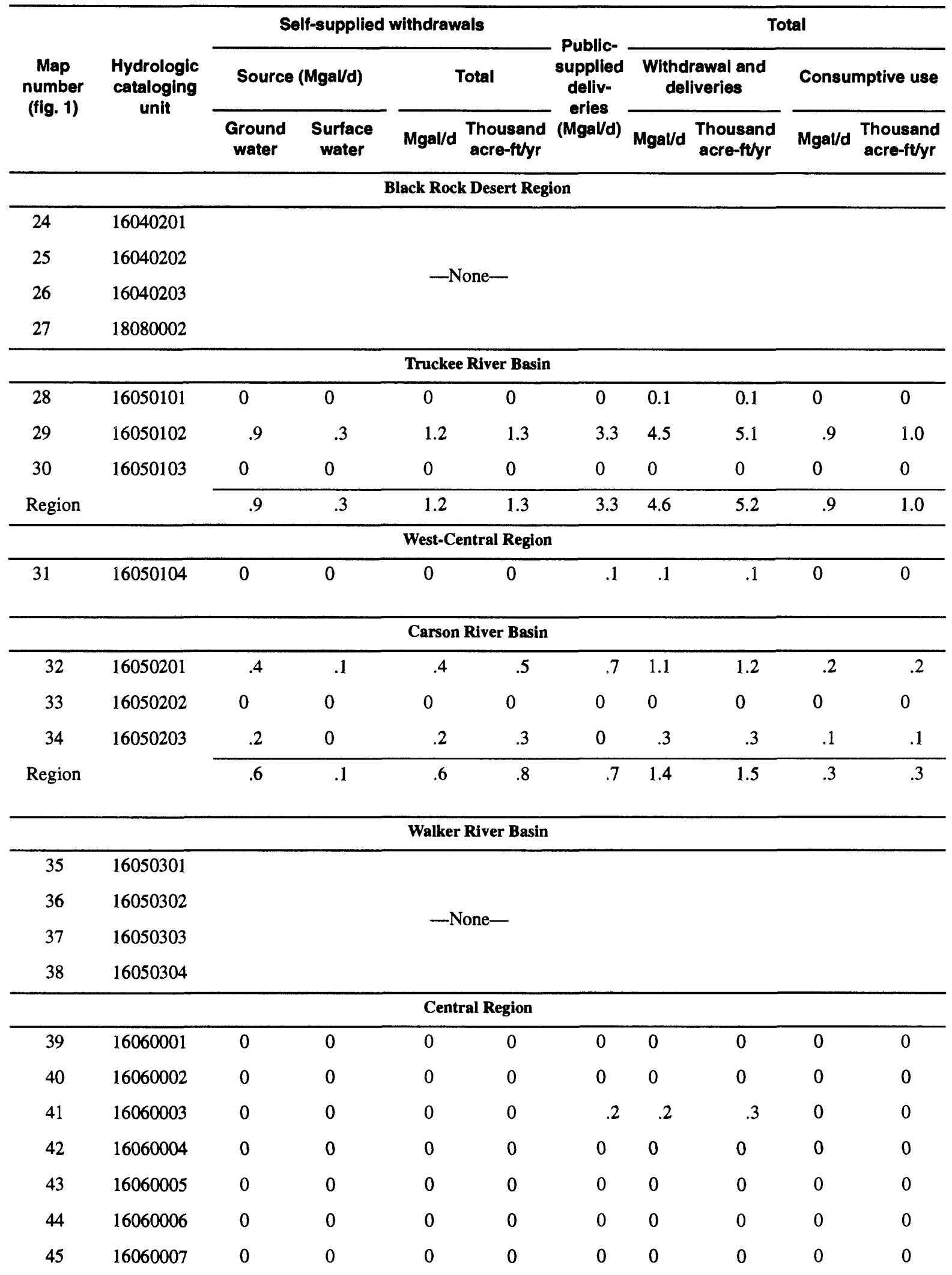


Table 16. Industrial water use in Nevada, by hydrologic cataloging unit, 1985-Continued

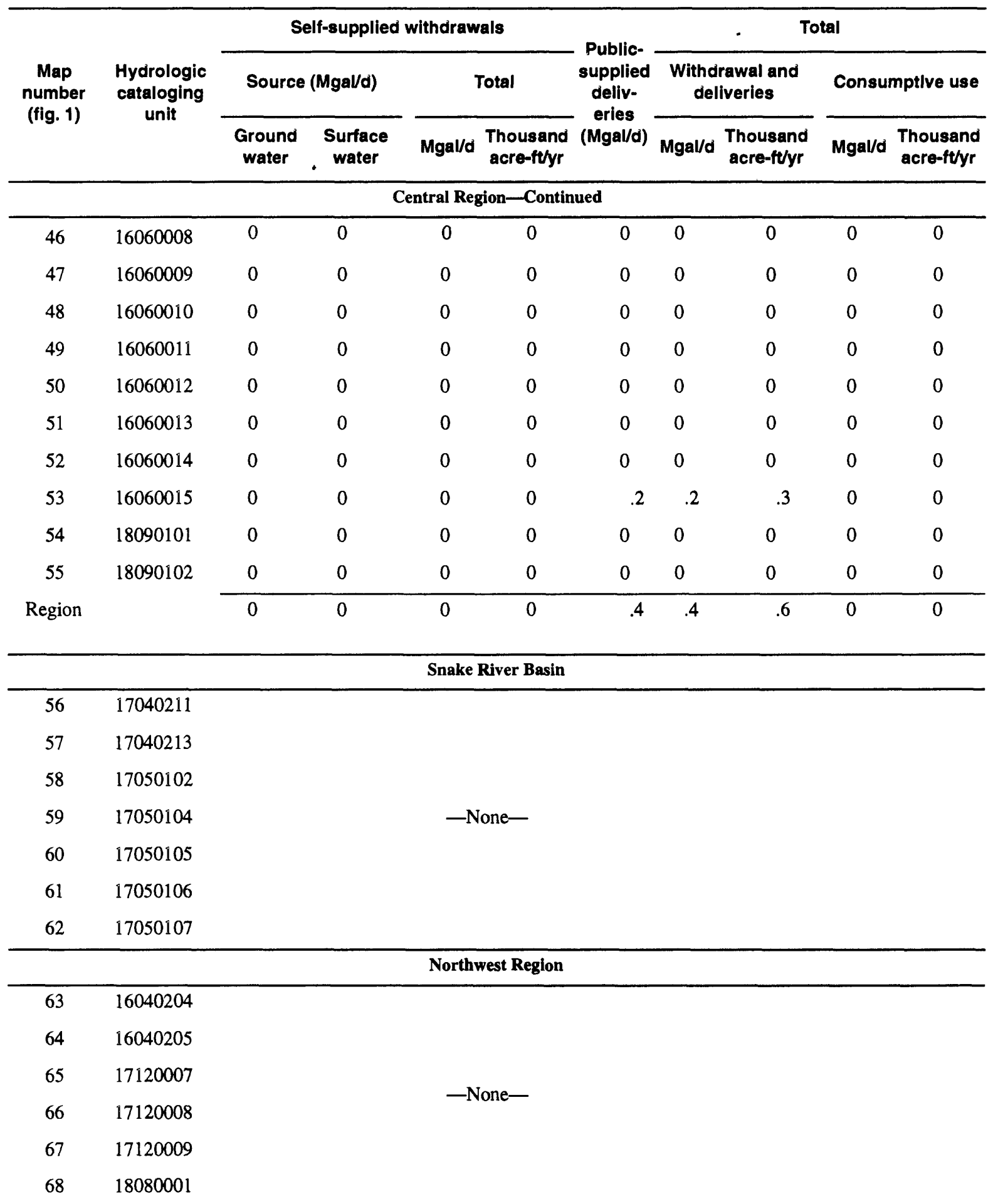


Table 16. Industrial water use in Nevada, by hydrologic cataloging unit, 1985-Continued

\begin{tabular}{|c|c|c|c|c|c|c|c|c|c|c|}
\hline \multirow{3}{*}{$\begin{array}{c}\text { Map } \\
\text { number } \\
\text { (fig. 1) }\end{array}$} & \multirow{3}{*}{$\begin{array}{c}\text { Hydrologic } \\
\text { cataloging } \\
\text { unit }\end{array}$} & \multicolumn{4}{|c|}{ Self-supplied withdrawals } & \multirow{3}{*}{$\begin{array}{l}\text { Public- } \\
\text { supplied } \\
\text { deliv- } \\
\text { eries } \\
\text { (Mgal/d) }\end{array}$} & \multicolumn{4}{|c|}{ Total } \\
\hline & & \multicolumn{2}{|c|}{ Source (Mgal/d) } & \multicolumn{2}{|c|}{ Total } & & \multicolumn{2}{|c|}{$\begin{array}{l}\text { Withdrawal and } \\
\text { deliveries }\end{array}$} & \multicolumn{2}{|c|}{ Consumptlve use } \\
\hline & & $\begin{array}{l}\text { Ground } \\
\text { water }\end{array}$ & $\begin{array}{l}\text { Surface } \\
\text { water }\end{array}$ & Mgal/d & $\begin{array}{l}\text { Thousand } \\
\text { acre-ft/yr }\end{array}$ & & Mgal/d & $\begin{array}{l}\text { Thousand } \\
\text { acre-ft/yr }\end{array}$ & Mgal/d & $\begin{array}{l}\text { Thousand } \\
\text { acre-ft/yr }\end{array}$ \\
\hline \multicolumn{11}{|c|}{ Western Region } \\
\hline 69 & 18080003 & 0 & 0 & 0 & 0 & 0.1 & 0.1 & 0.1 & 0 & 0 \\
\hline \multicolumn{11}{|c|}{ Death Valley Basin } \\
\hline 70 & 18090201 & 0 & 0 & 0 & 0 & 0 & 0 & 0 & 0 & 0 \\
\hline 71 & 18090202 & 0 & 0 & 0 & 0 & .1 & .1 & .1 & 0 & 0 \\
\hline 72 & 18090203 & 0 & 0 & 0 & 0 & 0 & 0 & 0 & 0 & 0 \\
\hline Region & & 0 & 0 & 0 & 0 & .1 & .1 & .1 & 0 & 0 \\
\hline STATE & & 2.4 & 7.8 & 10 & 11 & 6.3 & 16 & 18 & 3.2 & 3.6 \\
\hline
\end{tabular}


Table 17. Industrial water use in Nevada, by county, 1985

[All values rounded; State values rounded from summation of unrounded values. Abbreviations: acre-ft/yr, acre-feet per year; Mgal/d, million gallons per day]

\begin{tabular}{|c|c|c|c|c|c|c|c|c|c|}
\hline \multirow{3}{*}{ County } & \multicolumn{4}{|c|}{ Self-supplied withdrawals } & \multirow{3}{*}{$\begin{array}{l}\text { Public- } \\
\text { supplied } \\
\text { deliv- } \\
\text { eries } \\
\text { (Mgal/d) }\end{array}$} & \multicolumn{4}{|c|}{ Total } \\
\hline & \multicolumn{2}{|c|}{ Source (Mgal/d) } & \multicolumn{2}{|c|}{ Total } & & \multicolumn{2}{|c|}{$\begin{array}{l}\text { Withdrawal and } \\
\text { deliveries }\end{array}$} & \multicolumn{2}{|c|}{ Consumptive use } \\
\hline & $\begin{array}{l}\text { Ground } \\
\text { water }\end{array}$ & $\begin{array}{l}\text { Surface } \\
\text { water }\end{array}$ & Mgal/d & $\begin{array}{l}\text { Thousand } \\
\text { acre-ft/yr }\end{array}$ & & Mgal/d & $\begin{array}{l}\text { Thousand } \\
\text { acre-ft/yr }\end{array}$ & Mgal/d & $\begin{array}{l}\text { Thousand } \\
\text { acre-ft/yr }\end{array}$ \\
\hline Carson City & 0.2 & 0.1 & 0.3 & 0.3 & 0.6 & 0.9 & 1.0 & 0.2 & 0.2 \\
\hline Churchill & .2 & 0 & .2 & .3 & 0 & .3 & .3 & .1 & .1 \\
\hline Clark & 6 & 7.4 & 8.1 & 9.0 & 1.6 & 9.7 & 11 & 1.8 & 2.0 \\
\hline Douglas & .2 & 0 & .2 & .2 & .1 & .2 & .2 & 0 & 0 \\
\hline Elko & 0 & 0 & 0 & 0 & 0 & 0 & 0 & 0 & 0 \\
\hline Esmeralda & 0 & 0 & 0 & 0 & 0 & 0 & 0 & 0 & 0 \\
\hline Eureka & 0 & 0 & 0 & 0 & 0 & 0 & 0 & 0 & 0 \\
\hline Humboldt & .1 & .1 & .1 & .2 & .1 & .2 & .2 & 0 & 0 \\
\hline Lander & 0 & 0 & 0 & 0 & .1 & .1 & .1 & 0 & 0 \\
\hline Lincoln & 0 & 0 & 0 & 0 & 0 & 0 & 0 & 0 & 0 \\
\hline Lyon & 0 & 0 & 0 & 0 & .1 & .1 & .1 & 0 & 0 \\
\hline Mineral & 0 & 0 & 0 & 0 & 0 & 0 & 0 & 0 & 0 \\
\hline Nye & 0 & 0 & 0 & 0 & .3 & .3 & .4 & .1 & .1 \\
\hline Pershing & 0 & 0 & 0 & 0 & 0 & 0 & 0 & 0 & 0 \\
\hline Storey & 0 & 0 & 0 & 0 & 0 & 0 & 0 & 0 & 0 \\
\hline Washoe & 1.0 & .3 & 1.3 & 1.4 & 3.4 & 4.7 & 5.3 & .9 & 1.1 \\
\hline White Pine & 0 & 0 & 0 & 0 & 0 & 0 & 0 & 0 & 0 \\
\hline STATE & 2.4 & 7.8 & 10 & 11 & 6.3 & 16 & 18 & 3.2 & 3.6 \\
\hline
\end{tabular}


Table 18. Mining water use in Nevada, by hydrologic cataloging unit, 1985

[All values rounded: region and State values rounded from summation of unrounded values. Abbreviations: acre-ft/yr, acre-feet per year; Mgal/d, million gallons per day]

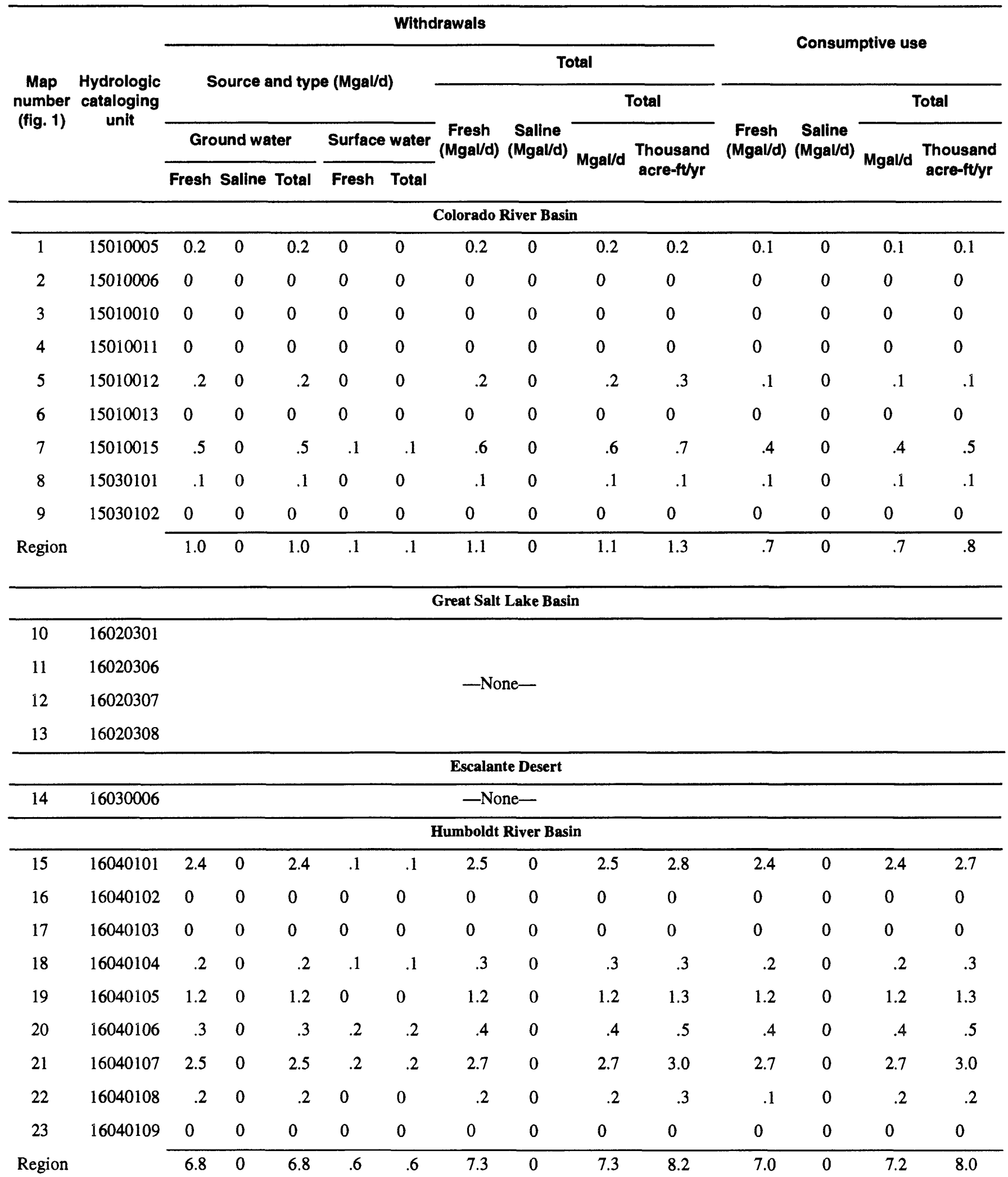


Table 18. Mining water use in Nevada, by hydrologic cataloging unit, 1985-Continued

\begin{tabular}{|c|c|c|c|c|c|c|c|c|c|c|c|c|c|c|}
\hline \multirow{5}{*}{$\begin{array}{l}\text { Map } \\
\text { number } \\
\text { (fig. 1) }\end{array}$} & \multirow{5}{*}{$\begin{array}{c}\text { Hydrologic } \\
\text { cataloging } \\
\text { unit }\end{array}$} & \multicolumn{9}{|c|}{ Withdrawals } & \multirow{2}{*}{\multicolumn{4}{|c|}{ Consumptive use }} \\
\hline & & \multirow{2}{*}{\multicolumn{5}{|c|}{ Source and type (Mgal/d) }} & \multicolumn{4}{|c|}{ Total } & & & & \\
\hline & & & & & & & \multirow{3}{*}{$\begin{array}{c}\text { Fresh } \\
(\mathrm{Mgal} / \mathrm{d})\end{array}$} & \multirow{3}{*}{$\begin{array}{c}\text { Saline } \\
\text { (Mgal/d) }\end{array}$} & \multicolumn{2}{|c|}{ Total } & \multirow{3}{*}{$\begin{array}{l}\text { Fresh } \\
\text { (Mgal/d) }\end{array}$} & \multirow{3}{*}{$\begin{array}{c}\text { Saline } \\
\text { (Mgal/d) }\end{array}$} & \multicolumn{2}{|r|}{ Total } \\
\hline & & Gro & ond wat & & Surface & water & & & \multirow{2}{*}{ Mgal/d } & \multirow{2}{*}{$\begin{array}{l}\text { Thousand } \\
\text { acre-ft/yr }\end{array}$} & & & \multirow{2}{*}{ Mgal/d } & \multirow{2}{*}{$\begin{array}{l}\text { Thousand } \\
\text { acre-ft/yr }\end{array}$} \\
\hline & & Fresh & Saline & Total & Fresh & Total & & & & & & & & \\
\hline \multicolumn{15}{|c|}{ Black Rock Desert Region } \\
\hline 24 & 16040201 & 0.8 & 0 & 0.8 & 0 & 0 & 0.8 & 0 & 0.8 & 0.9 & 0.8 & 0 & 0.8 & 0.9 \\
\hline 25 & 16040202 & .2 & 0 & .2 & 0 & 0 & .2 & 0 & .2 & .2 & .2 & 0 & .2 & .2 \\
\hline 26 & 16040203 & .1 & 0 & .1 & 0 & 0 & .1 & 0 & .1 & .1 & .1 & 0 & .1 & .1 \\
\hline 27 & 18080002 & 0 & 0 & 0 & 0 & 0 & 0 & 0 & 0 & 0 & 0 & 0 & 0 & 0 \\
\hline Region & & 1.1 & 0 & 1.1 & 0 & 0 & 1.1 & 0 & 1.1 & 1.2 & 1.1 & 0 & 1.1 & 1.2 \\
\hline \multicolumn{15}{|c|}{ Truckee River Basin } \\
\hline 28 & 16050101 & 0 & 0 & 0 & 0 & 0 & 0 & 0 & 0 & 0 & 0 & 0 & 0 & 0 \\
\hline 29 & 16050102 & .3 & 0 & .3 & 0 & 0 & .3 & 0 & .3 & .3 & .1 & 0 & .1 & .2 \\
\hline 30 & 16050103 & .1 & 0 & .1 & 0 & 0 & .1 & 0 & .1 & .1 & .1 & 0 & .1 & .1 \\
\hline Region & & .4 & 0 & .4 & 0 & 0 & .4 & 0 & .4 & .4 & .2 & 0 & .2 & .3 \\
\hline \multicolumn{15}{|c|}{ West-Central Region } \\
\hline 31 & 16050104 & .4 & 0 & .4 & 0 & 0 & .4 & 0 & .4 & .4 & .3 & 0 & .3 & .4 \\
\hline \multicolumn{15}{|c|}{ Carson River Basin } \\
\hline 32 & 16050201 & 0 & 0 & 0 & 0 & 0 & 0 & 0 & 0 & 0 & 0 & 0 & 0 & 0 \\
\hline 33 & 16050202 & .3 & 0 & .3 & 0 & 0 & .3 & 0 & .3 & .4 & .2 & 0 & .2 & .2 \\
\hline 34 & 16050203 & .1 & 0 & .2 & 0 & .1 & .2 & .1 & .2 & .3 & .1 & .1 & .2 & .2 \\
\hline Region & & .4 & 0 & .5 & 0 & .1 & .5 & .1 & .5 & .7 & .3 & .1 & .4 & .4 \\
\hline \multicolumn{15}{|c|}{ Walker River Basin } \\
\hline 35 & 16050301 & .3 & 0 & .3 & 0 & 0 & .3 & 0 & .3 & .4 & .3 & 0 & .3 & .4 \\
\hline 36 & 16050302 & .3 & 0 & .3 & 0 & 0 & .3 & 0 & .3 & .4 & .2 & 0 & .2 & .2 \\
\hline 37 & 16050303 & 0 & 0 & 0 & 0 & 0 & 0 & 0 & 0 & 0 & 0 & 0 & 0 & 0 \\
\hline 38 & 16050304 & 0 & 0 & 0 & 0 & 0 & 0 & 0 & 0 & 0 & 0 & 0 & 0 & 0 \\
\hline Region & & .6 & 0 & .6 & 0 & 0 & .6 & 0 & .6 & 8 & .5 & 0 & .5 & .6 \\
\hline
\end{tabular}

\begin{tabular}{rrrrrrrrrrrrrrrr}
\hline \multicolumn{11}{c}{ Central Region } \\
\hline 39 & 16060001 & .1 & 0 & .1 & 0 & 0 & .1 & 0 & .1 & .2 & .1 & 0 & .1 & .1 \\
40 & 16060002 & .4 & 0 & .4 & 0 & 0 & .4 & 0 & .4 & .4 & .3 & 0 & .3 & .3 \\
41 & 16060003 & .5 & 0 & .5 & .1 & .1 & .6 & 0 & .6 & .6 & .6 & 0 & .6 & .7 \\
42 & 16060004 & 2.1 & 0 & 2.1 & 1.6 & 1.6 & 3.7 & 0 & 3.7 & 4.1 & 3.6 & 0 & 3.6 & 4.0
\end{tabular}


Table 18. Mining water use in Nevada, by hydrologic cataloging unit, 1985—Continued

\begin{tabular}{|c|c|c|c|c|c|c|c|c|c|c|c|c|c|c|}
\hline \multirow{5}{*}{$\begin{array}{c}\text { Map } \\
\text { number } \\
\text { (fig. 1) }\end{array}$} & \multirow{5}{*}{$\begin{array}{c}\text { Hydrologic } \\
\text { cataloging } \\
\text { unit }\end{array}$} & \multicolumn{9}{|c|}{ Withdrawals } & \multirow{2}{*}{\multicolumn{4}{|c|}{ Consumptive use }} \\
\hline & & \multirow{2}{*}{\multicolumn{5}{|c|}{ Source and type (Mgal/d) }} & \multicolumn{4}{|c|}{ Total } & & & & \\
\hline & & & & & & & \multirow{3}{*}{$\begin{array}{c}\text { Fresh } \\
(\text { Mgal/d) }\end{array}$} & \multirow{3}{*}{$\begin{array}{c}\text { Saline } \\
\text { (Mgal/d) }\end{array}$} & \multicolumn{2}{|r|}{ Total } & \multirow{3}{*}{$\begin{array}{c}\text { Fresh } \\
\text { (Mgal/d) }\end{array}$} & \multirow{3}{*}{$\begin{array}{l}\text { Saline } \\
\text { (Mgal/d) }\end{array}$} & \multicolumn{2}{|r|}{ Total } \\
\hline & & \multicolumn{3}{|c|}{ Ground water } & \multicolumn{2}{|c|}{ Surface water } & & & \multirow{2}{*}{ Mgal/d } & \multirow{2}{*}{$\begin{array}{l}\text { Thousand } \\
\text { acre-ft/yr }\end{array}$} & & & \multirow{2}{*}{ Mgal/d } & \multirow{2}{*}{$\begin{array}{l}\text { Thousanc } \\
\text { acre-ft/yr }\end{array}$} \\
\hline & & Fresh & Saline & Total & Fresh & Total & & & & & & & & \\
\hline \multicolumn{15}{|c|}{ Central Region-Continued } \\
\hline 43 & 16060005 & 0.3 & 0 & 0.3 & 0 & 0 & 0.3 & 0 & 0.3 & 0.3 & 0.2 & 0 & 0.2 & 0.2 \\
\hline 44 & 16060006 & 0 & 0 & 0 & 0 & 0 & .1 & 0 & .1 & .1 & 0 & 0 & 0 & 0 \\
\hline 45 & 16060007 & .7 & 0 & .7 & .1 & .1 & .8 & 0 & .8 & .9 & .6 & 0 & .6 & .7 \\
\hline 46 & 16060008 & .5 & 0 & .5 & 0 & 0 & .5 & 0 & .5 & .6 & .3 & 0 & .3 & .4 \\
\hline 47 & 16060009 & 0 & 0 & 0 & 0 & 0 & 0 & 0 & 0 & 0 & 0 & 0 & 0 & 0 \\
\hline 48 & 16060010 & .3 & 0 & .3 & 0 & 0 & .3 & 0 & .3 & .3 & .2 & 0 & .2 & .2 \\
\hline 49 & 16060011 & 1.5 & 8.3 & 9.8 & .1 & .1 & 1.5 & 8.3 & 9.8 & 11 & .4 & 8.3 & 8.7 & 9.7 \\
\hline 50 & 16060012 & 0 & 0 & 0 & 0 & 0 & 0 & 0 & 0 & 0 & 0 & 0 & 0 & 0 \\
\hline 51 & 16060013 & 0 & 0 & 0 & 0 & 0 & 0 & 0 & 0 & 0 & 0 & 0 & 0 & 0 \\
\hline 52 & 16060014 & 0 & 0 & 0 & 0 & 0 & 0 & 0 & 0 & 0 & 0 & 0 & 0 & 0 \\
\hline 53 & 16060015 & .1 & 0 & .1 & 0 & 0 & .1 & 0 & .1 & .1 & 0 & 0 & 0 & 0 \\
\hline 54 & 18090101 & 0 & 0 & 0 & 0 & 0 & 0 & 0 & 0 & 0 & 0 & 0 & 0 & 0 \\
\hline 55 & 18090102 & 0 & 0 & 0 & 0 & 0 & 0 & 0 & 0 & 0 & 0 & 0 & 0 & 0 \\
\hline Region & & 6.5 & 8.3 & 15 & 1.9 & 1.9 & 8.4 & 8.3 & 17 & 19 & 6.3 & 8.3 & 15 & 16 \\
\hline \multicolumn{15}{|c|}{ Snake River Basin } \\
\hline 56 & 17040211 & 0 & 0 & 0 & 0 & 0 & 0 & 0 & 0 & 0 & 0 & 0 & 0 & 0 \\
\hline 57 & 17040213 & 0 & 0 & 0 & 0 & 0 & 0 & 0 & 0 & 0 & 0 & 0 & 0 & 0 \\
\hline 58 & 17050102 & 0 & 0 & 0 & 0 & 0 & 0 & 0 & 0 & 0 & 0 & 0 & 0 & 0 \\
\hline 59 & 17050104 & 0 & 0 & 0 & 0 & 0 & 0 & 0 & 0 & 0 & 0 & 0 & 0 & 0 \\
\hline 60 & 17050105 & 1.7 & 0 & 1.7 & 0 & 0 & 1.7 & 0 & 1.7 & 1.9 & 1.6 & 0 & 1.6 & 1.8 \\
\hline 61 & 17050106 & 0 & 0 & 0 & 0 & 0 & 0 & 0 & 0 & 0 & 0 & 0 & 0 & 0 \\
\hline 62 & 17050107 & 0 & 0 & 0 & 0 & 0 & 0 & 0 & 0 & 0 & 0 & 0 & 0 & 0 \\
\hline Region & & 1.7 & 0 & 1.7 & 0 & 0 & 1.7 & 0 & 1.7 & 1.9 & 1.6 & 0 & 1.6 & 1.8 \\
\hline \multicolumn{15}{|c|}{ Northwest Region } \\
\hline 63 & 16040204 & & & & & & \multirow{6}{*}{\multicolumn{2}{|c|}{-None- }} & & & & & & \\
\hline 64 & 16040205 & & & & & & & & & & & & & \\
\hline 65 & 17120007 & & & & & & & & & & & & & \\
\hline 66 & 17120008 & & & & & & & & & & & & & \\
\hline 67 & 17120009 & & & & & & & & & & & & & \\
\hline 68 & 18080001 & & & & & & & & & & & & & \\
\hline
\end{tabular}


Table 18. Mining water use in Nevada, by hydrologic cataloging unit, 1985-Continued

\begin{tabular}{|c|c|c|c|c|c|c|c|c|c|c|c|c|c|c|}
\hline \multirow{5}{*}{$\begin{array}{c}\text { Map } \\
\text { number } \\
\text { (fig. 1) }\end{array}$} & \multirow{5}{*}{$\begin{array}{l}\text { Hydrologic } \\
\text { cataloging } \\
\text { unit }\end{array}$} & \multicolumn{9}{|c|}{ Withdrawals } & \multirow{2}{*}{\multicolumn{4}{|c|}{ Consumptive use }} \\
\hline & & \multirow{2}{*}{\multicolumn{5}{|c|}{ Source and type (Mgal/d) }} & \multicolumn{4}{|c|}{ Total } & & & & \\
\hline & & & & & & & \multirow{3}{*}{$\begin{array}{c}\text { Fresh } \\
\text { (Mgal/d) }\end{array}$} & \multirow{3}{*}{$\begin{array}{c}\text { Saline } \\
\text { (Mgal/d) }\end{array}$} & \multicolumn{2}{|c|}{ Total } & \multirow{3}{*}{$\begin{array}{c}\text { Fresh } \\
\text { (Mgal/d) }\end{array}$} & \multirow{3}{*}{$\begin{array}{c}\text { Saline } \\
\text { (Mgal/d) }\end{array}$} & \multicolumn{2}{|r|}{ Total } \\
\hline & & \multicolumn{3}{|c|}{ Ground water } & \multicolumn{2}{|c|}{ Surface water } & & & \multirow{2}{*}{ Mgal/d } & \multirow{2}{*}{$\begin{array}{l}\text { Thousand } \\
\text { acre-ft/yr }\end{array}$} & & & \multirow{2}{*}{ Mgal/d } & \multirow{2}{*}{$\begin{array}{l}\text { Thousano } \\
\text { acre-ft/yr }\end{array}$} \\
\hline & & Fresh & Saline & Total & Fresh & Total & & & & & & & & \\
\hline \multicolumn{15}{|c|}{ Western Regior: } \\
\hline 69 & 18080003 & & & & & & $-\mathrm{No}$ & $\overline{\text { ne- }}$ & & & & & & \\
\hline \multicolumn{15}{|c|}{ Death Valley Basin } \\
\hline 70 & 18090201 & 0 & 0 & 0 & 0 & 0 & 0 & 0 & 0 & 0 & 0 & 0 & 0 & 0 \\
\hline 71 & 18090202 & .1 & 0 & .1 & 0 & 0 & .1 & 0 & .1 & .1 & 0 & 0 & 0 & 0 \\
\hline 72 & 18090203 & 0 & 0 & 0 & 0 & 0 & 0 & 0 & 0 & 0 & 0 & 0 & 0 & 0 \\
\hline Region & & .1 & 0 & .1 & 0 & 0 & .1 & 0 & .1 & .1 & 0 & 0 & 0 & 0 \\
\hline STATE & & 19 & 8.4 & 27 & 2.7 & 2.7 & 22 & 8.4 & 30 & 33 & 18 & 8.4 & 27 & 30 \\
\hline
\end{tabular}




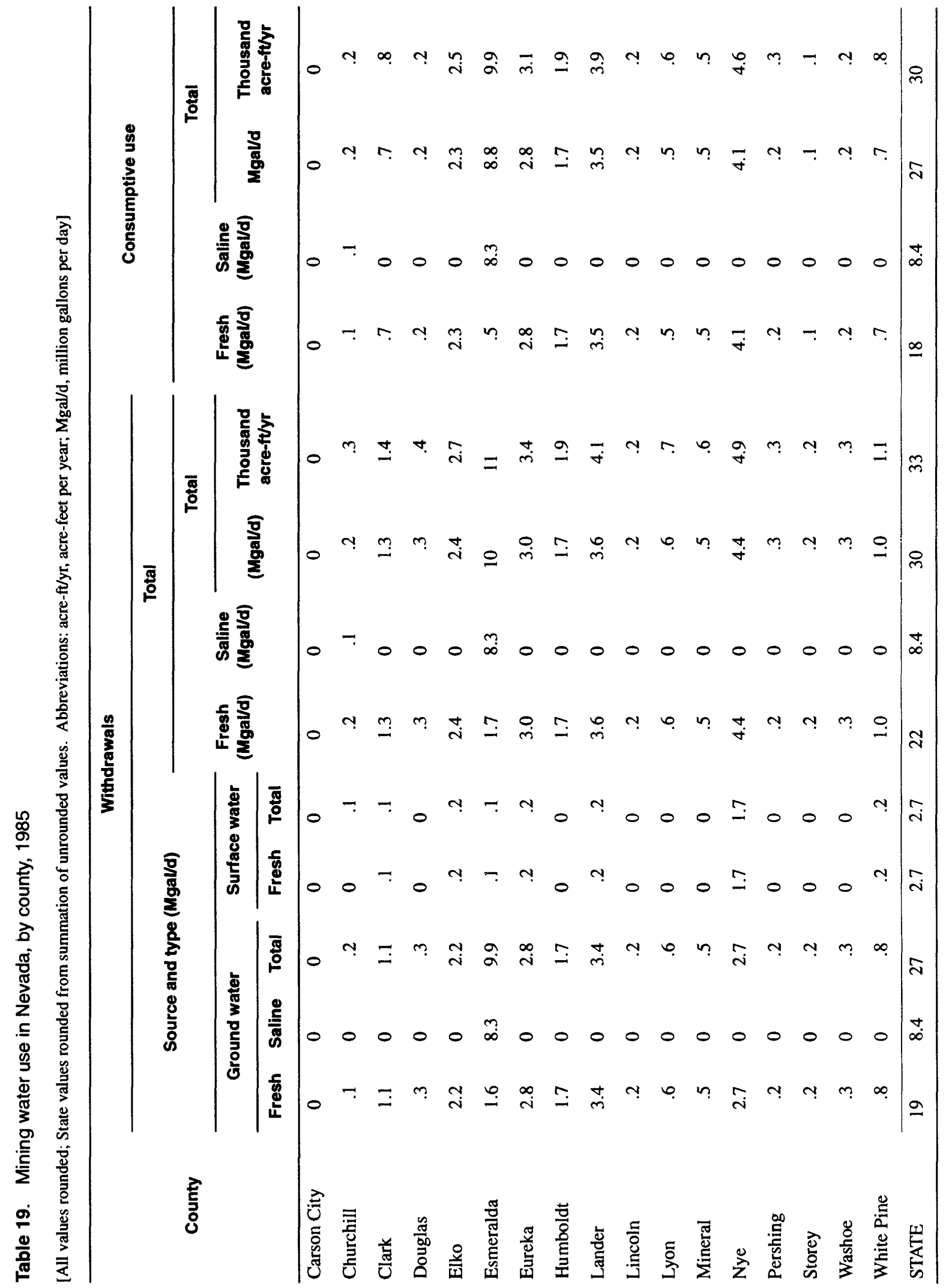




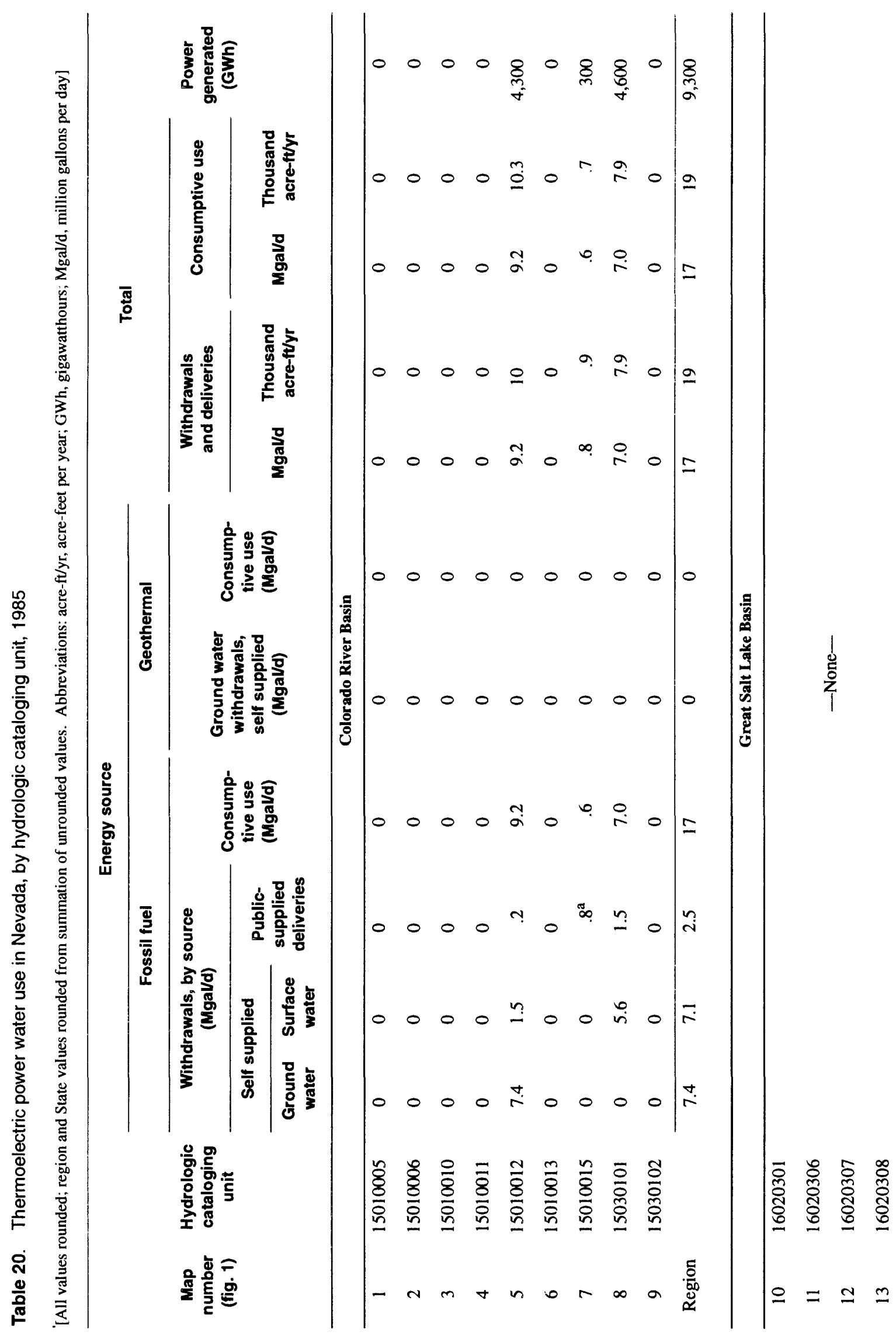




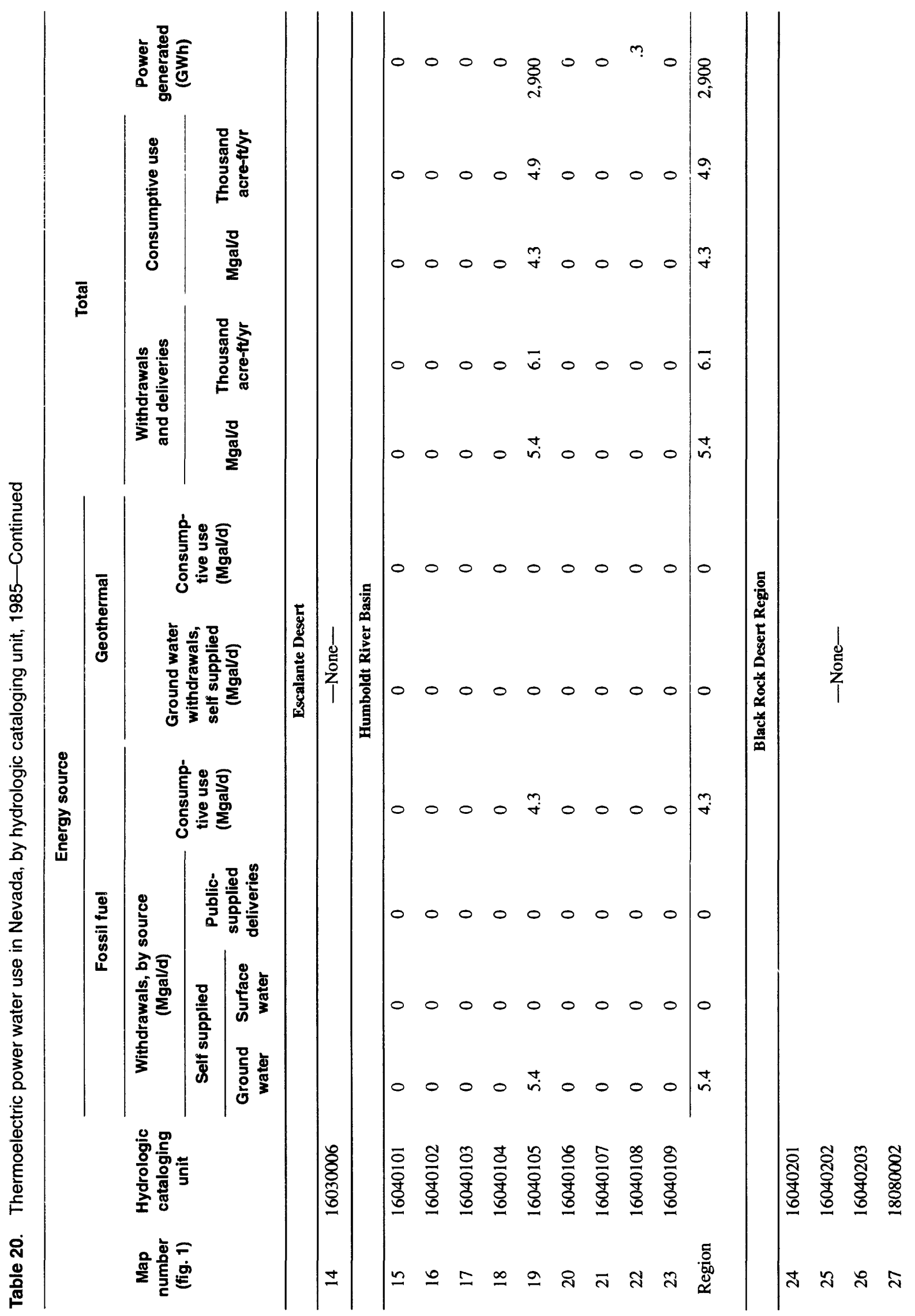




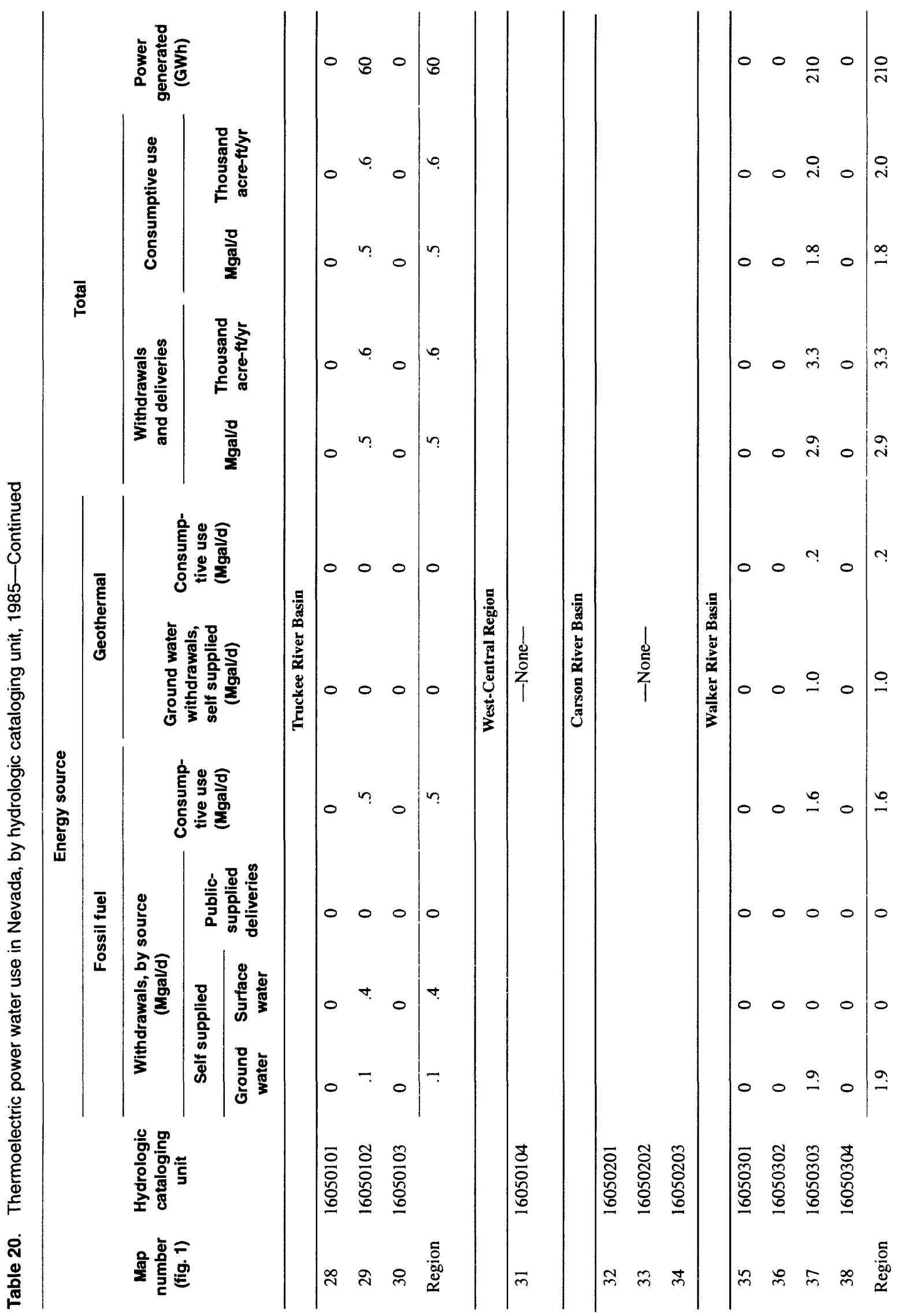

Table $20 \quad 109$ 


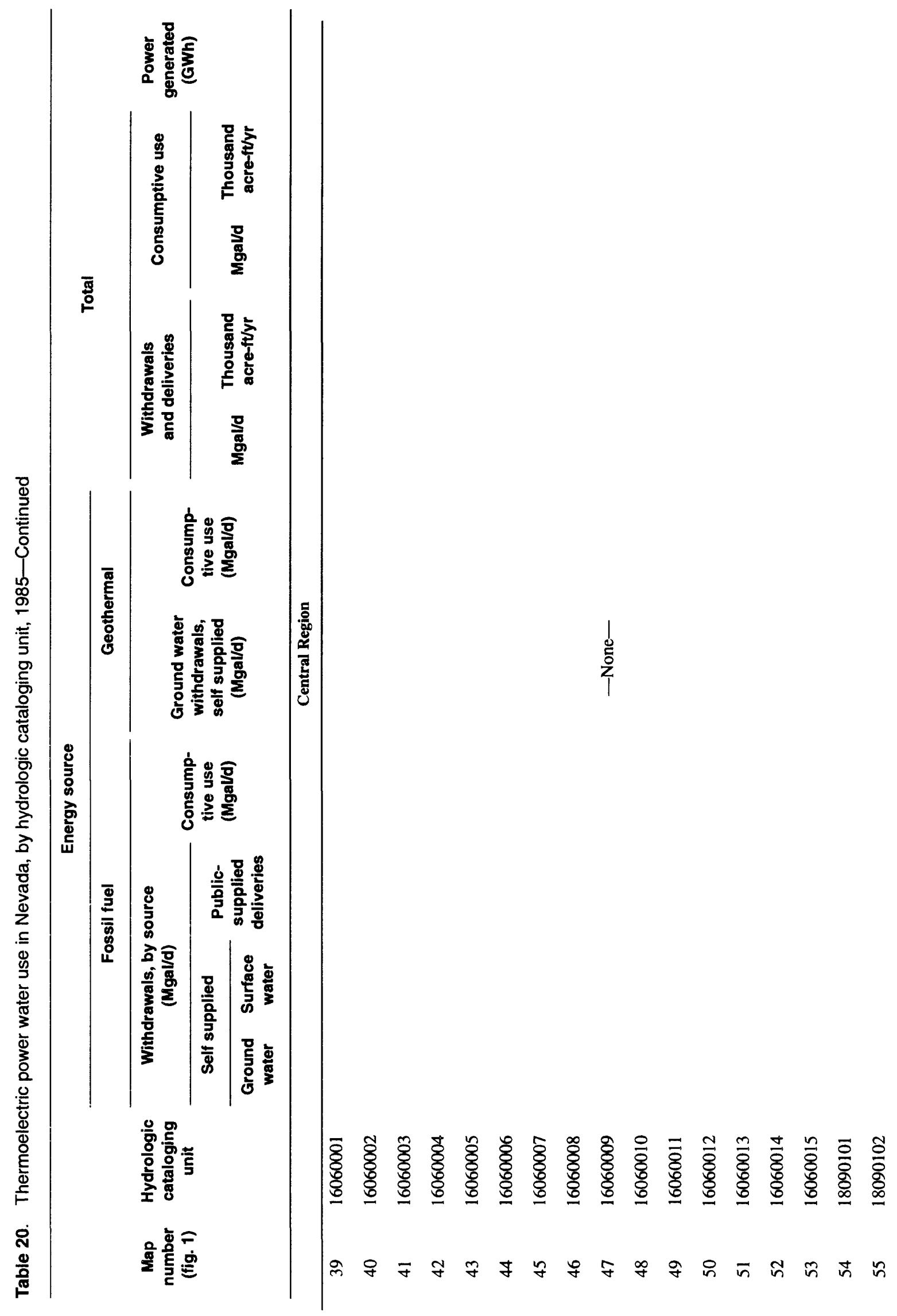




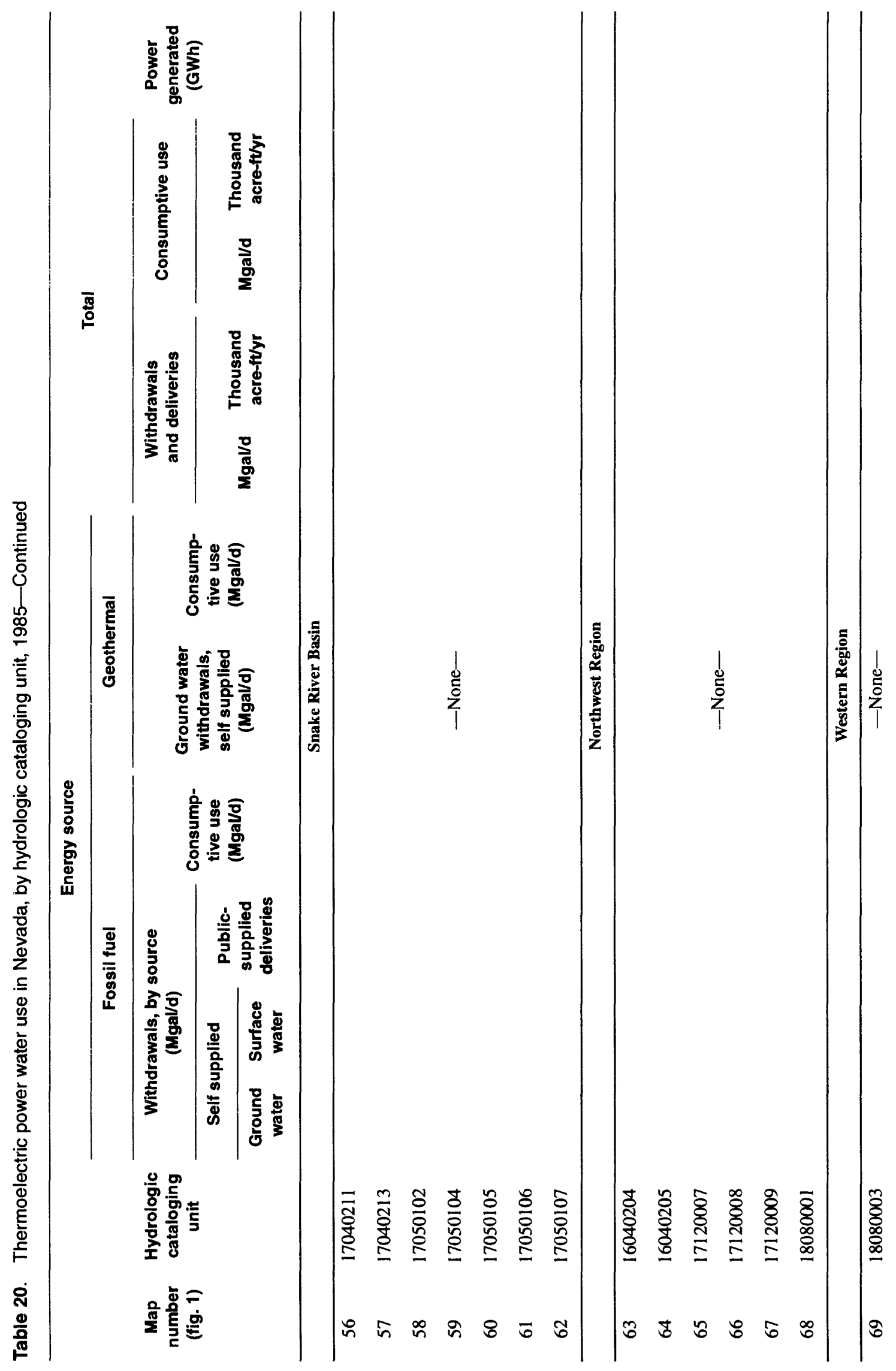




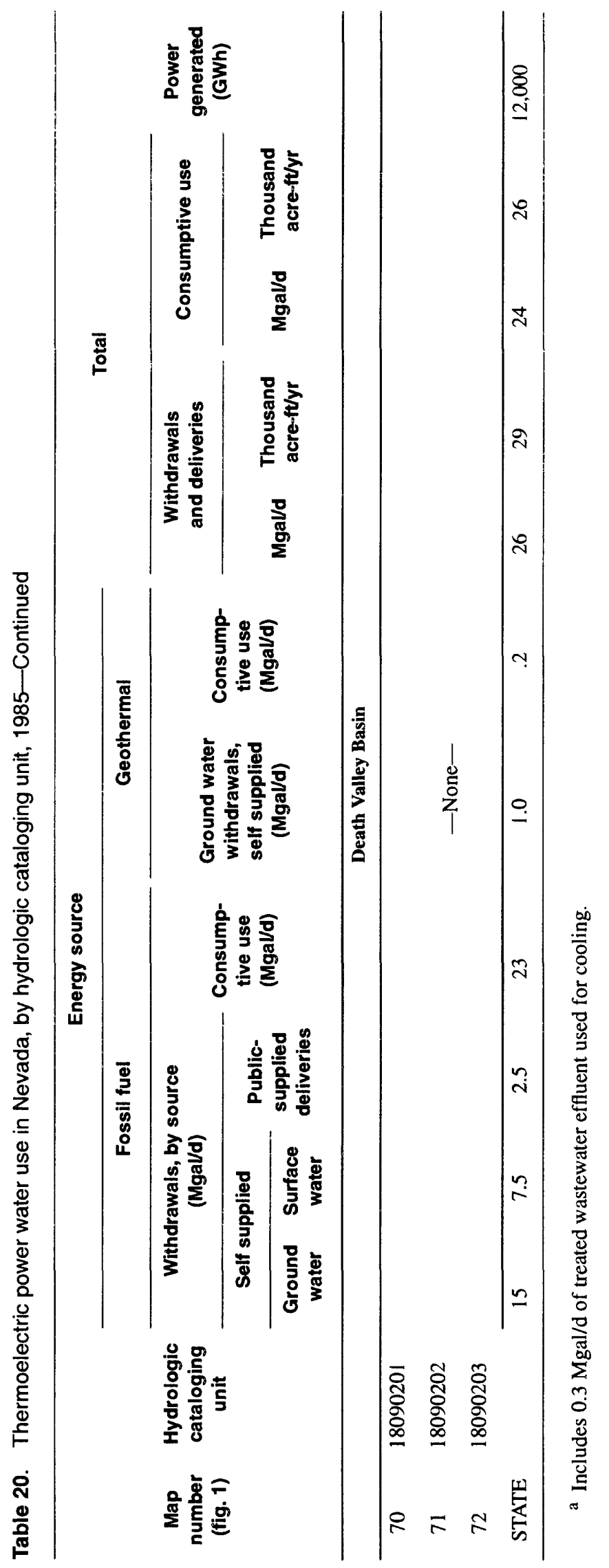




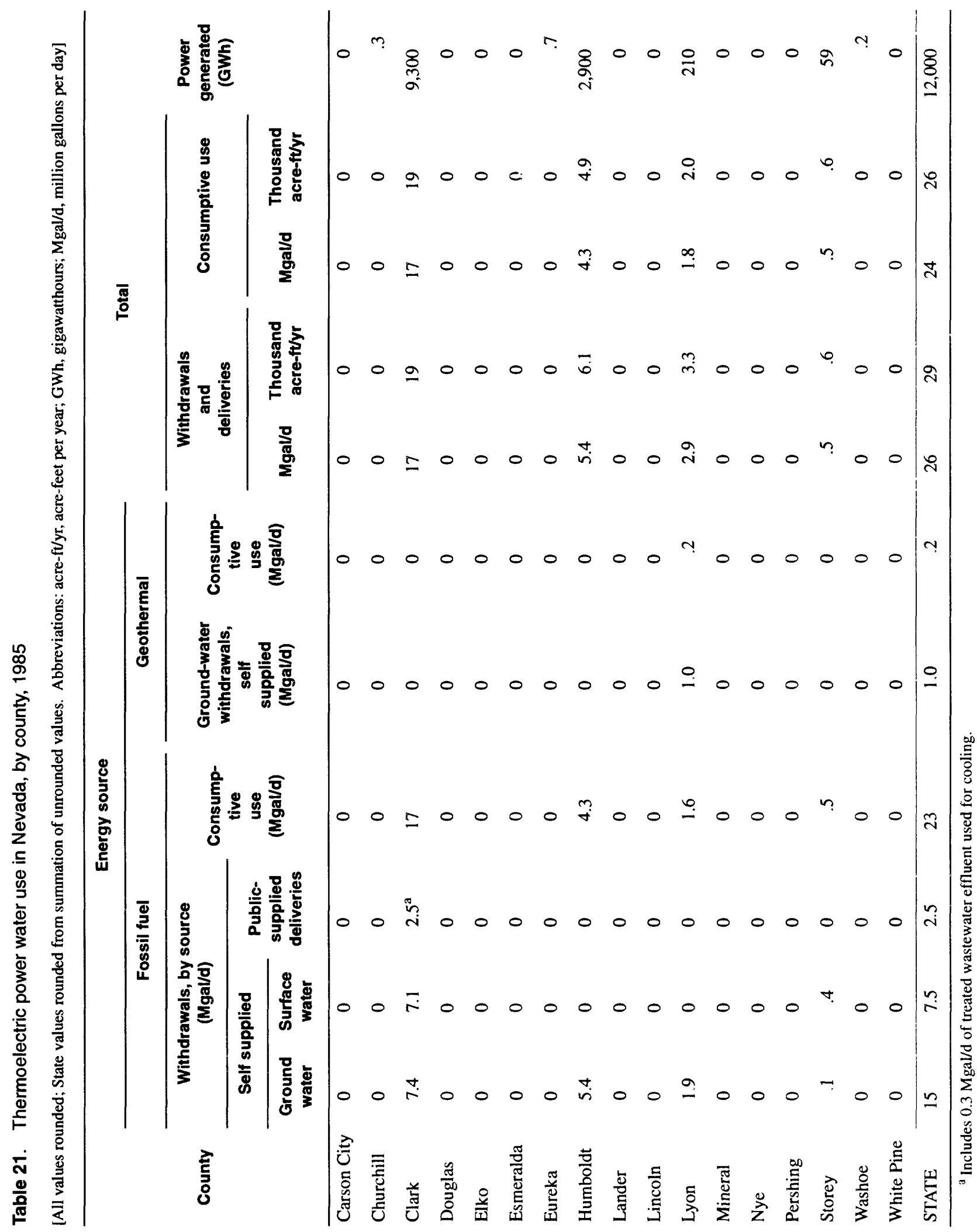




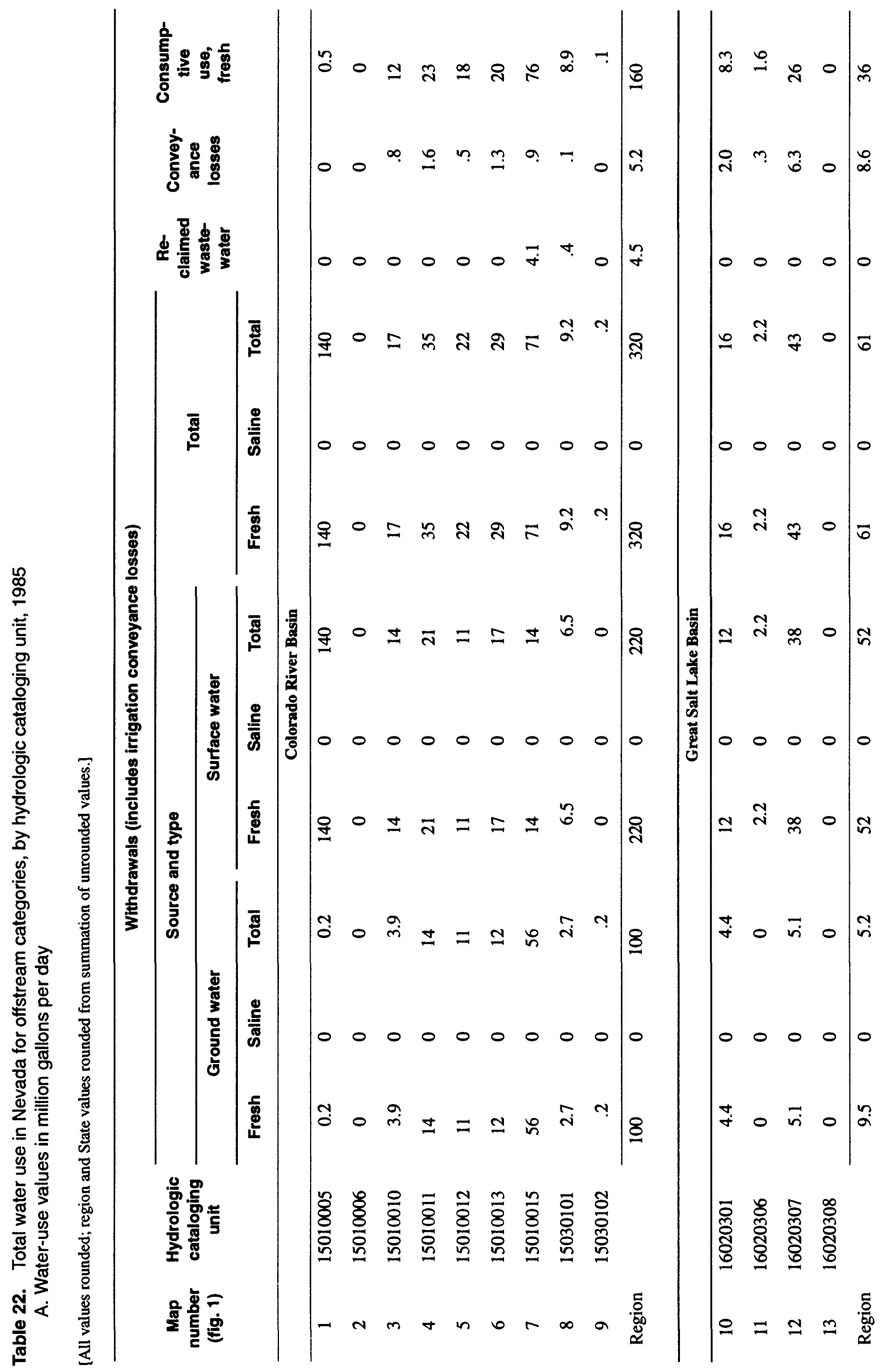




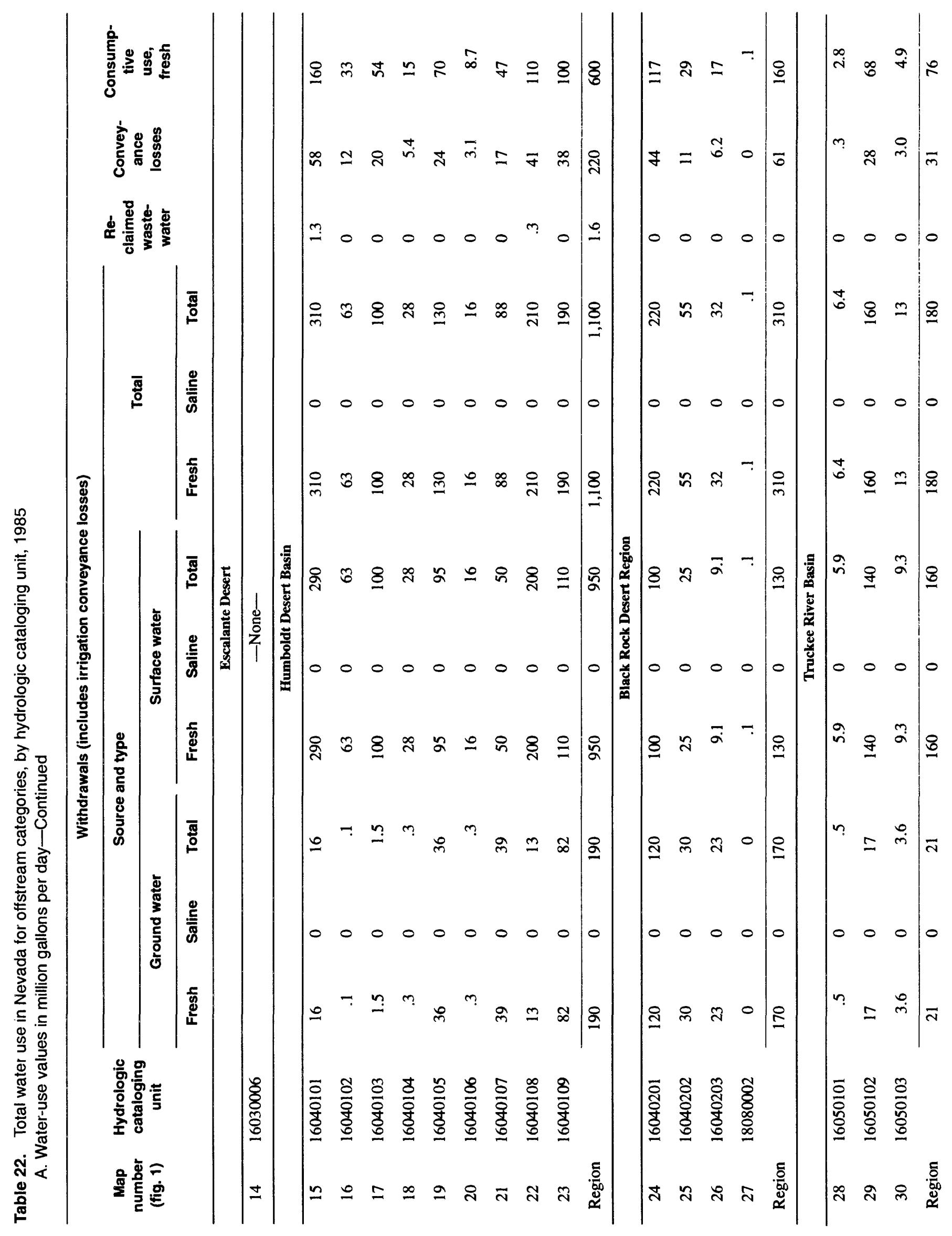




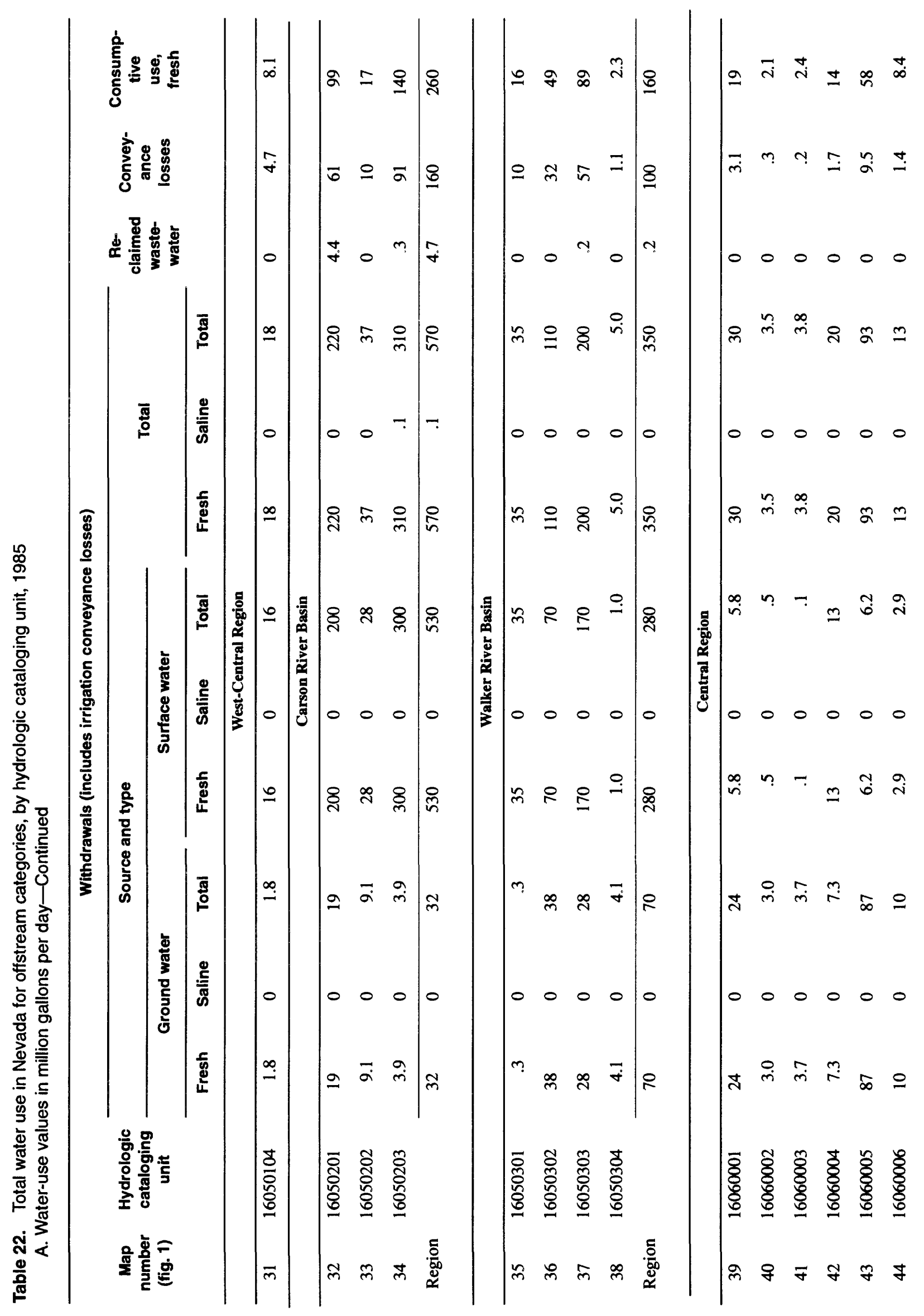




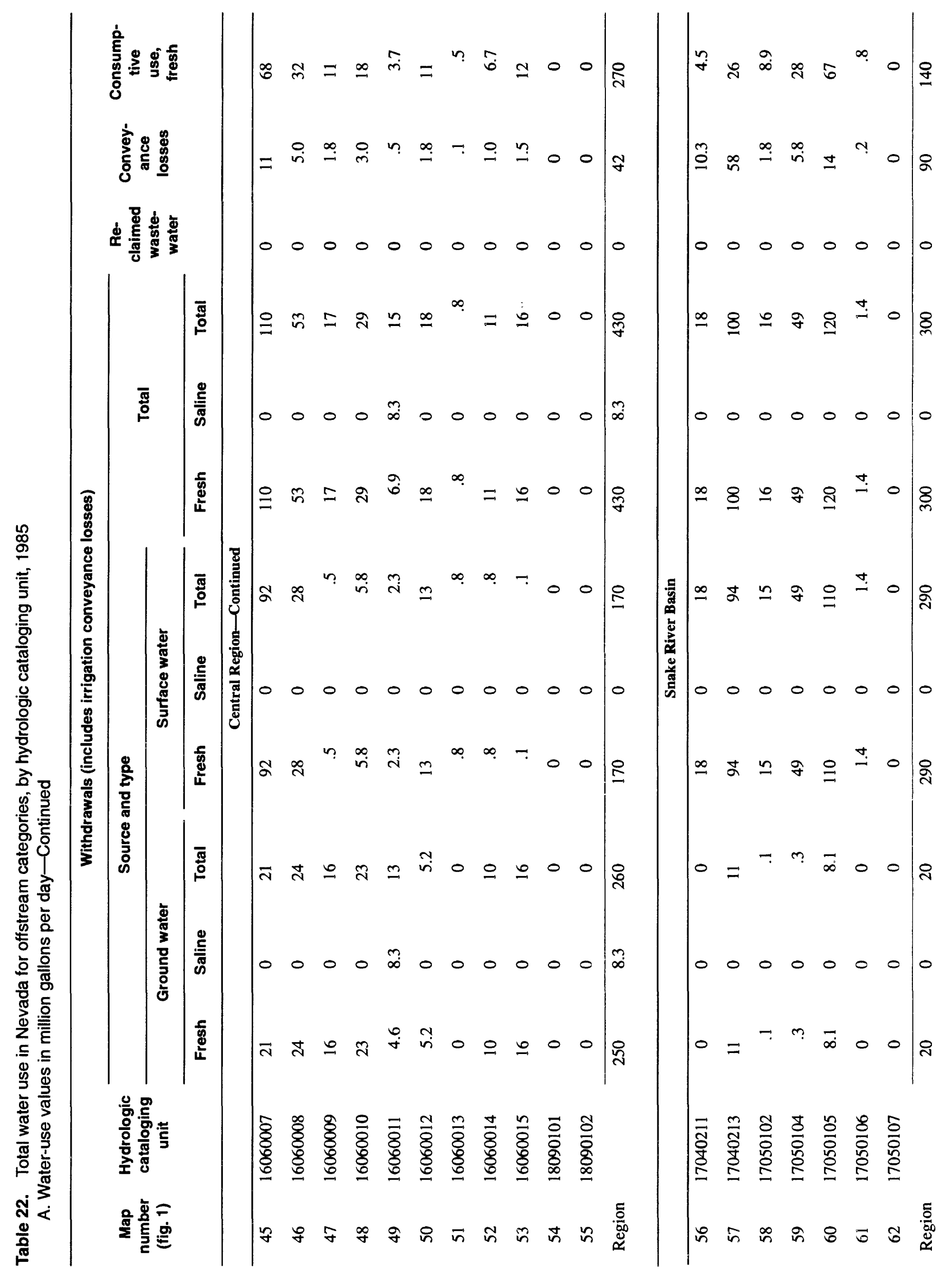




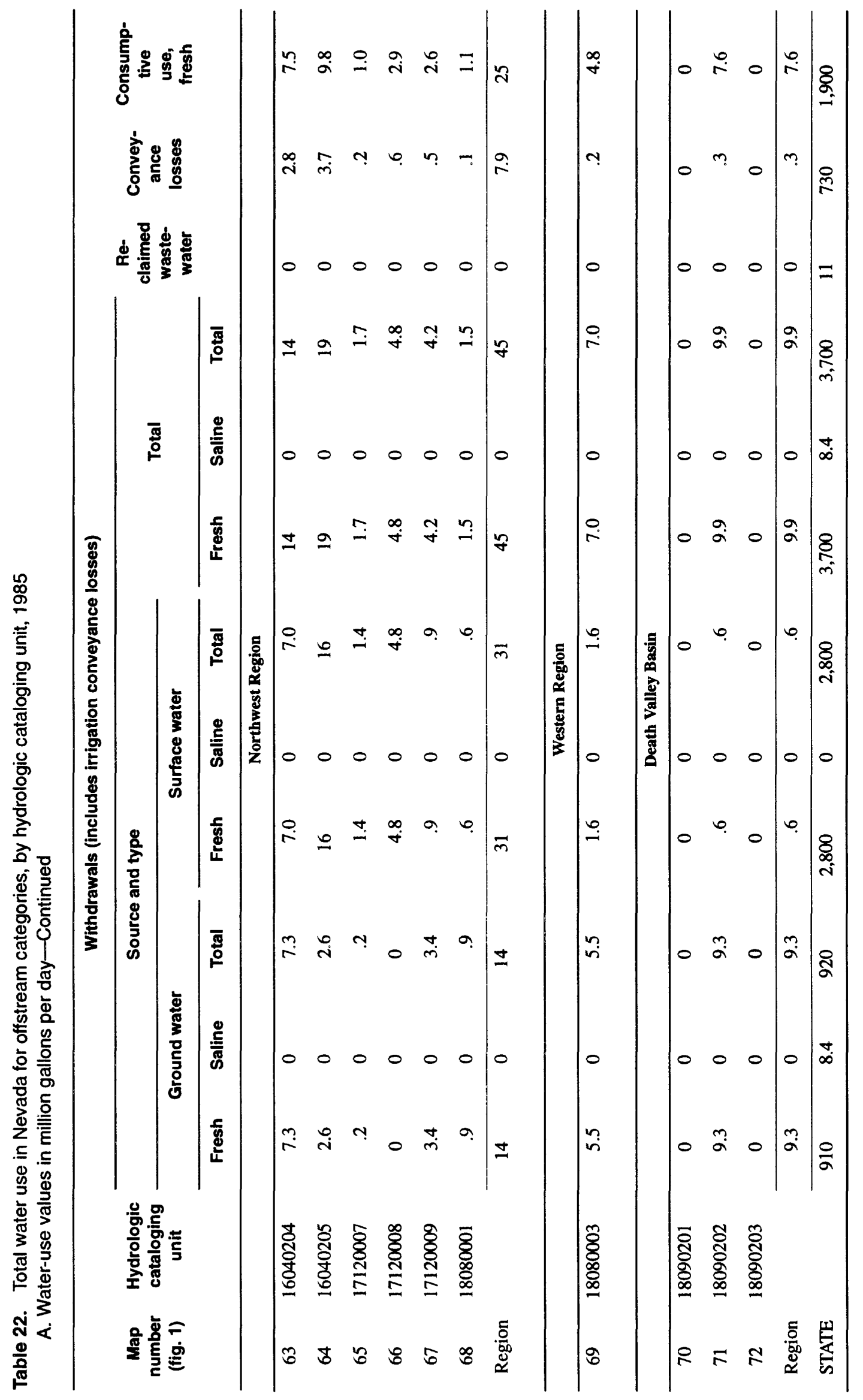




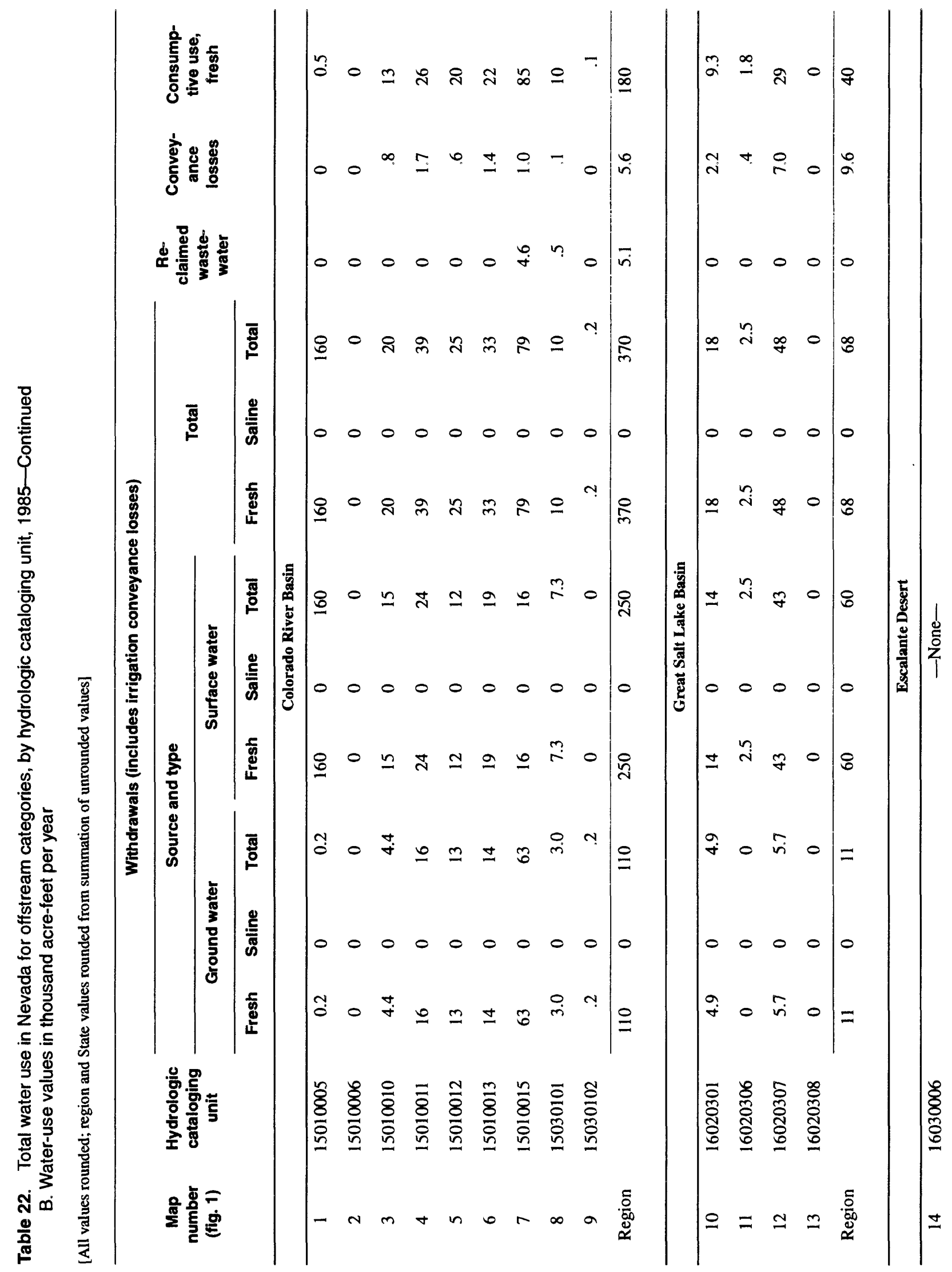




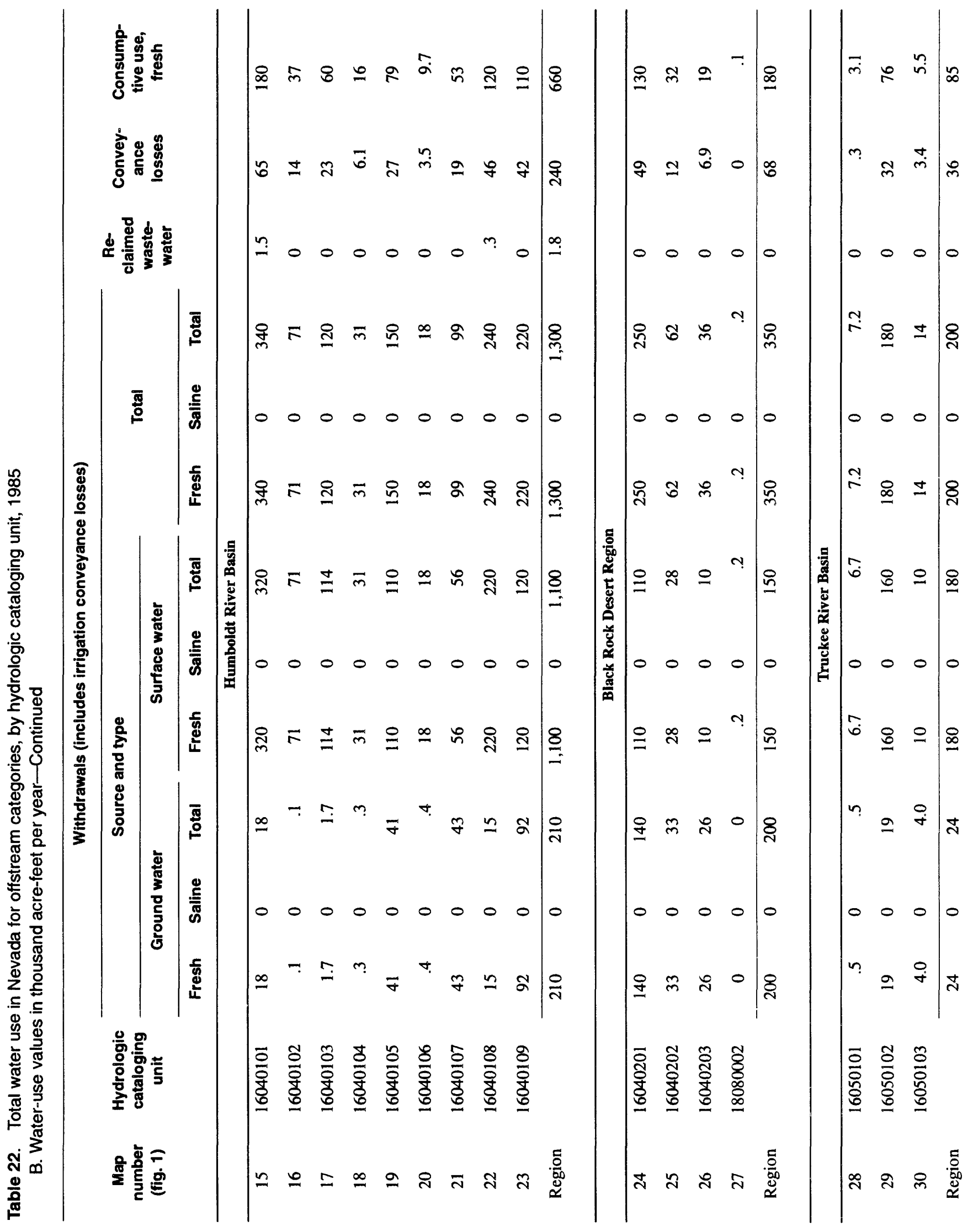




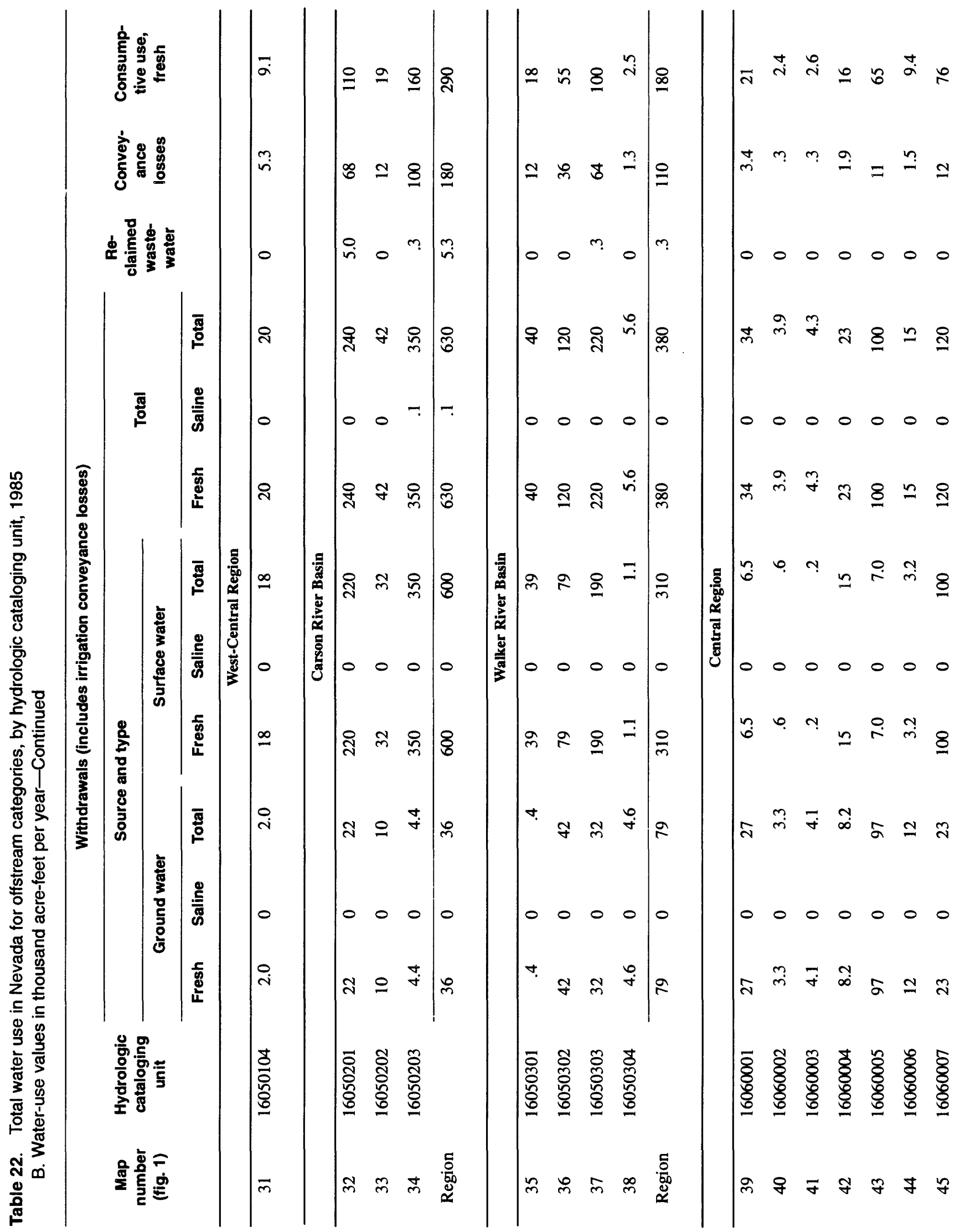




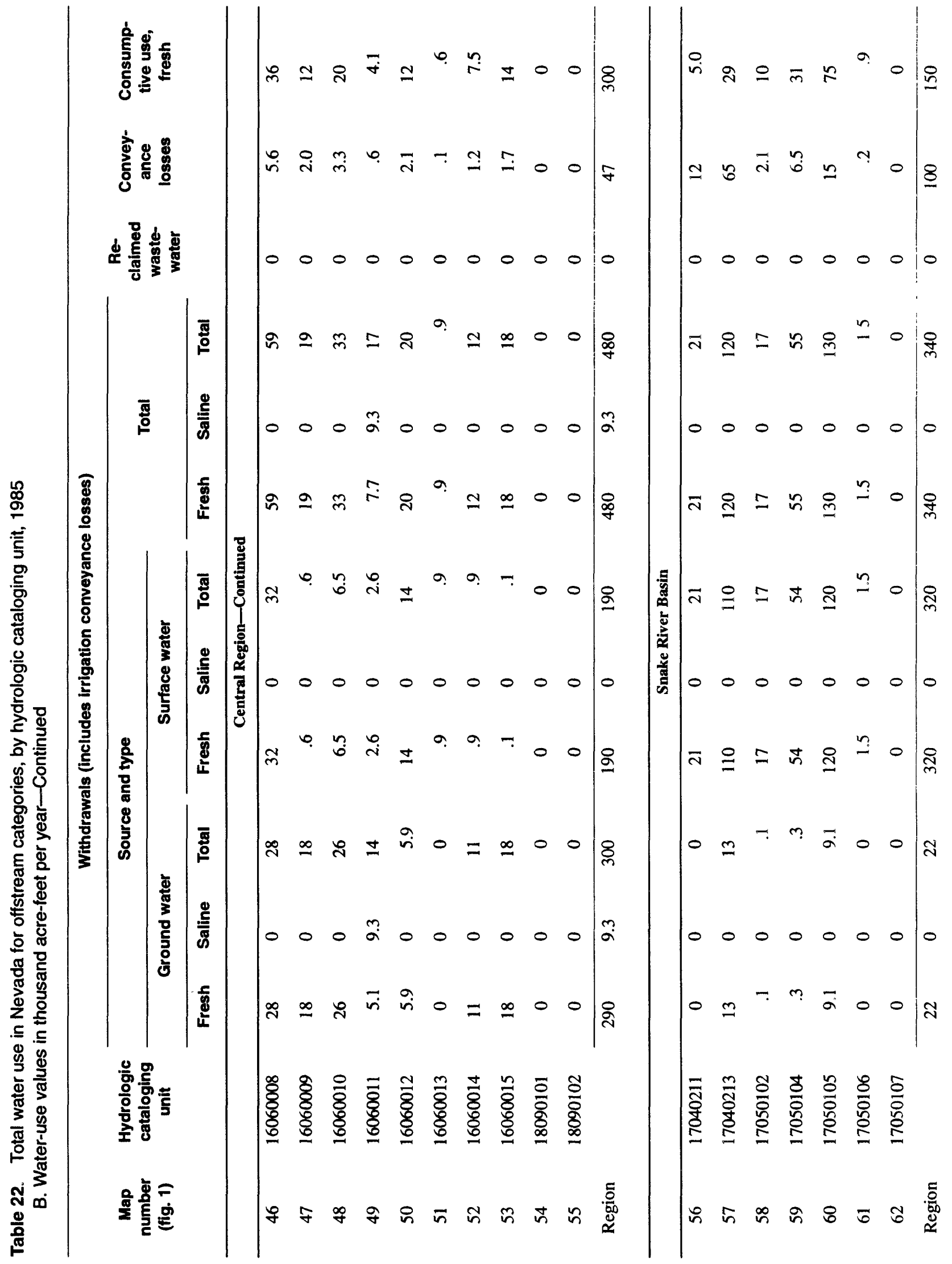




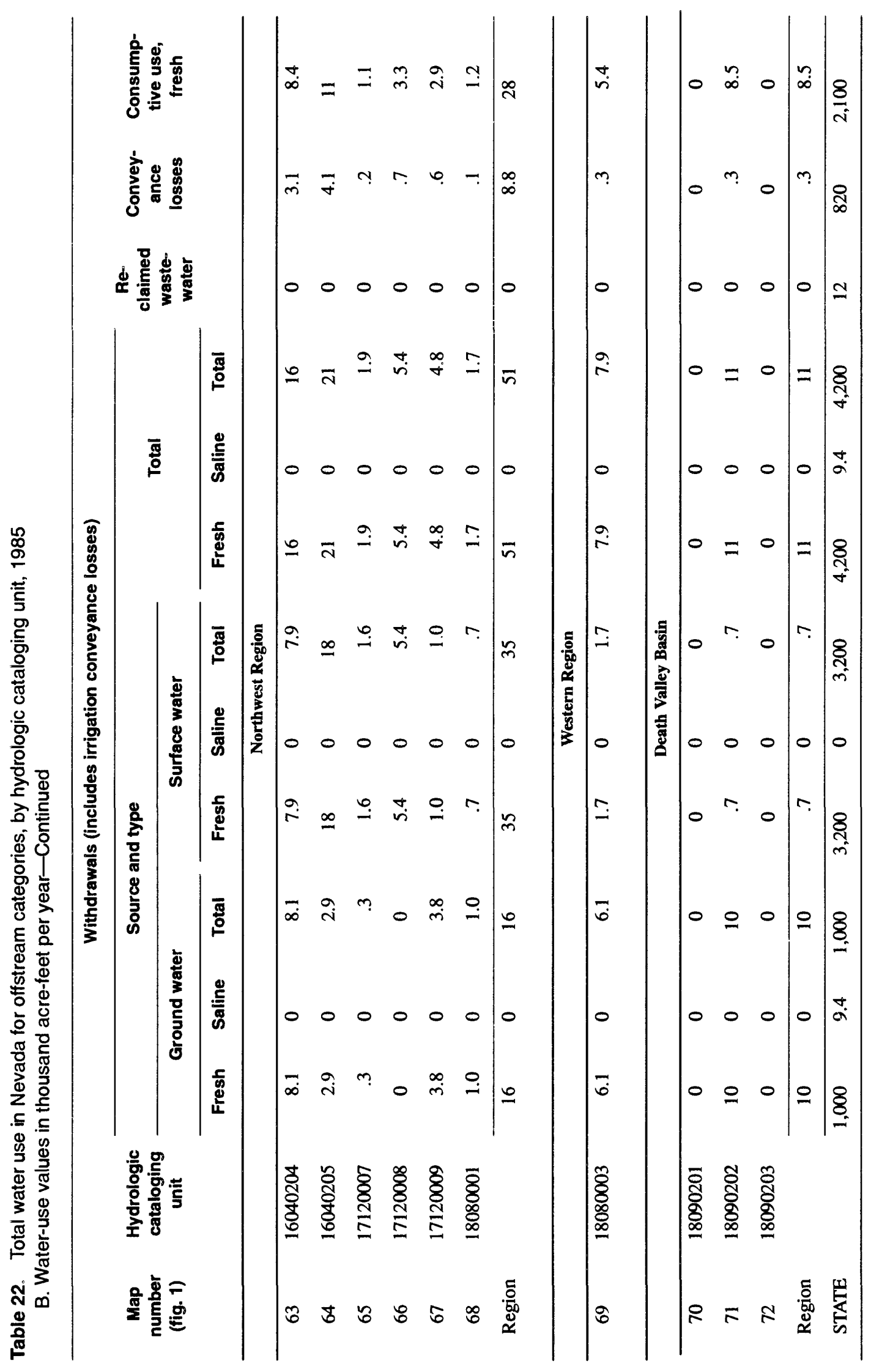




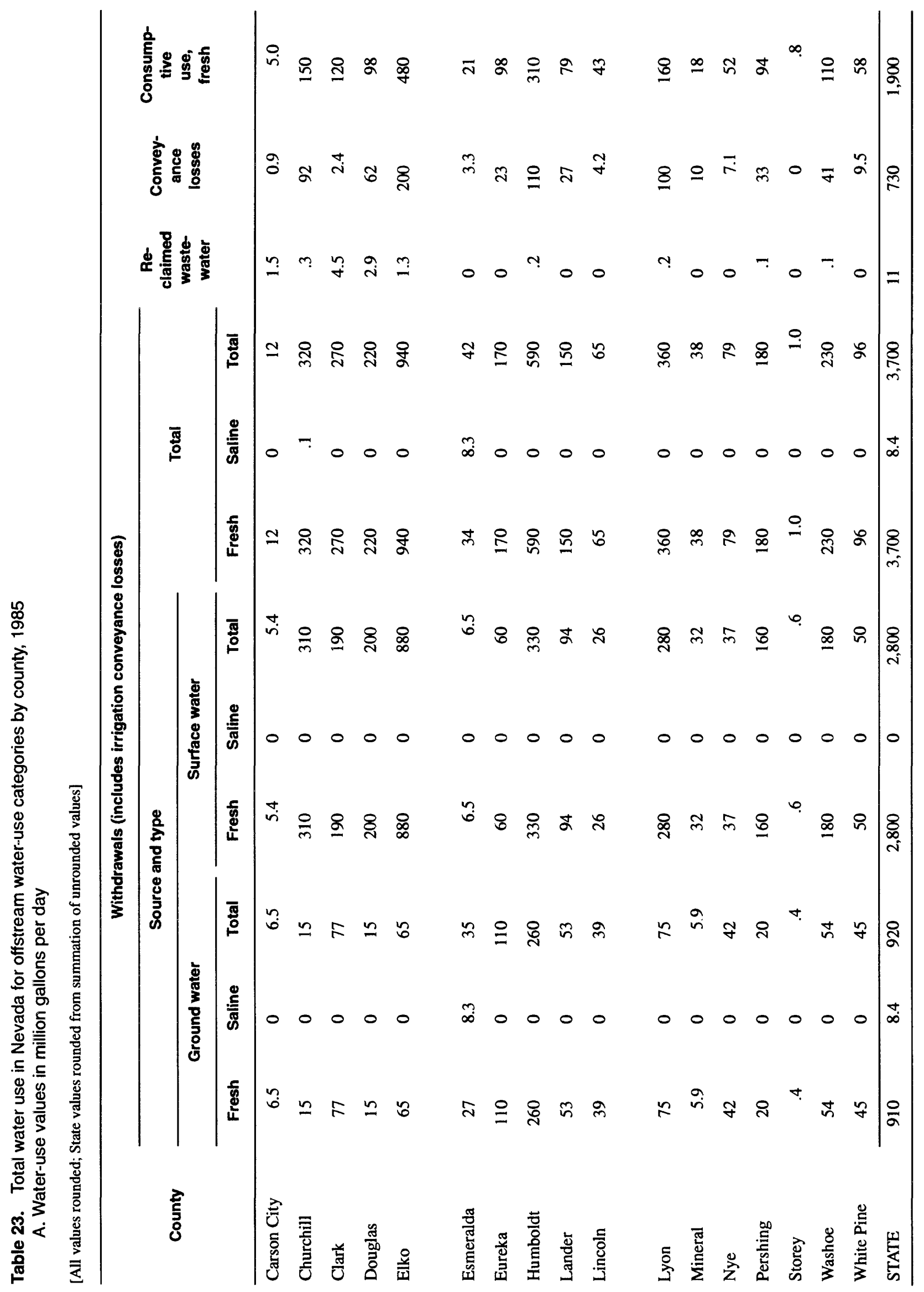




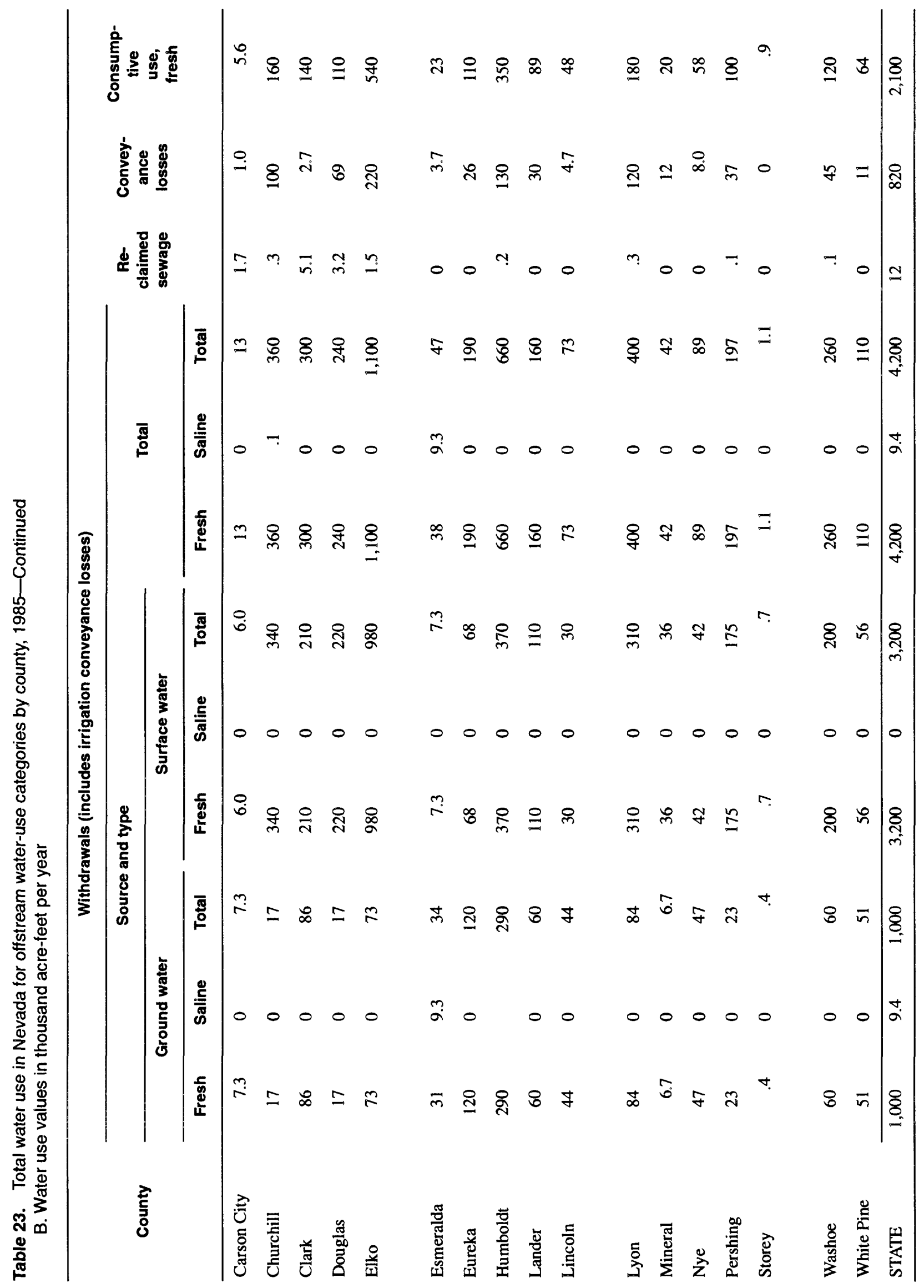




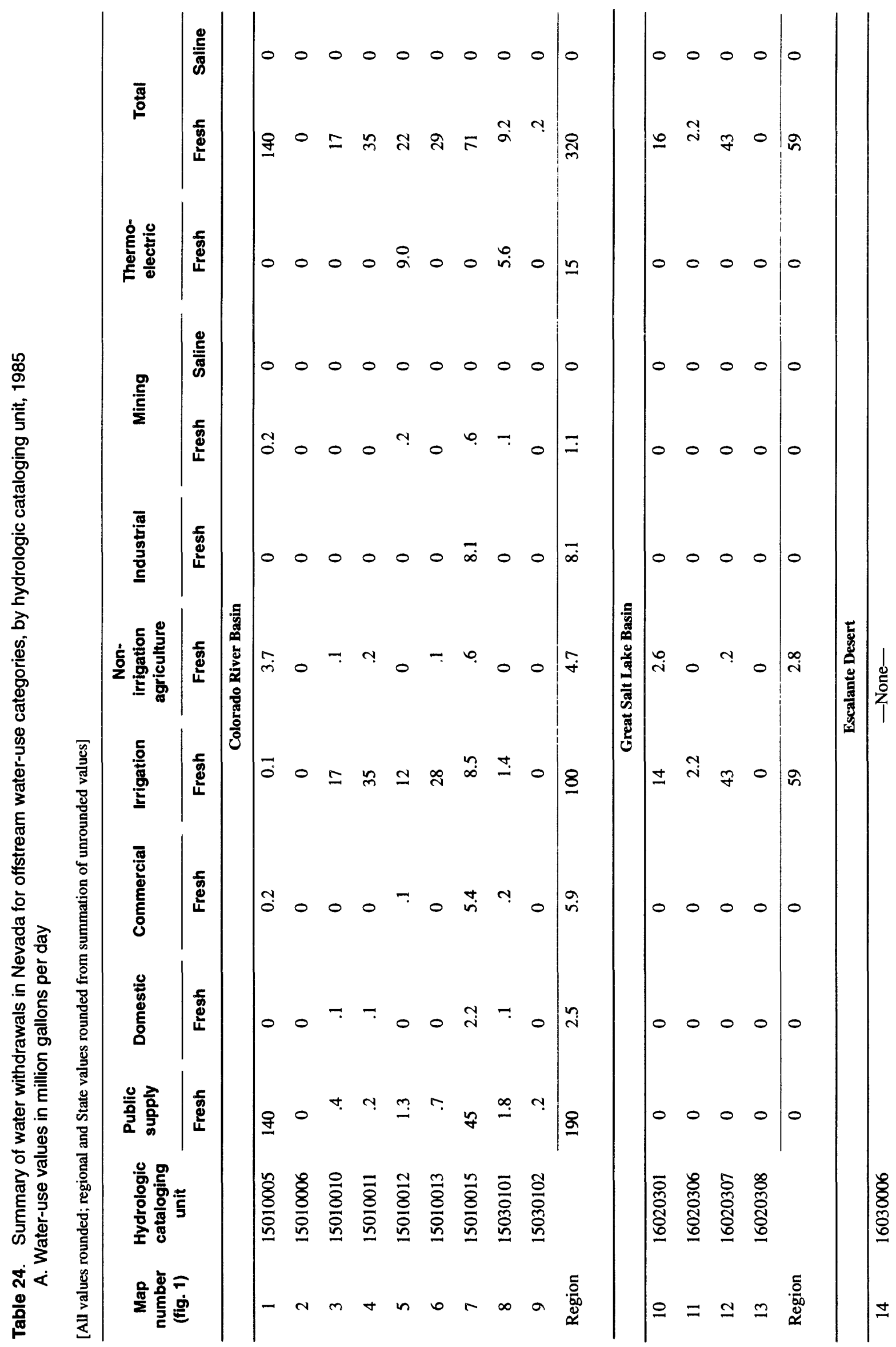




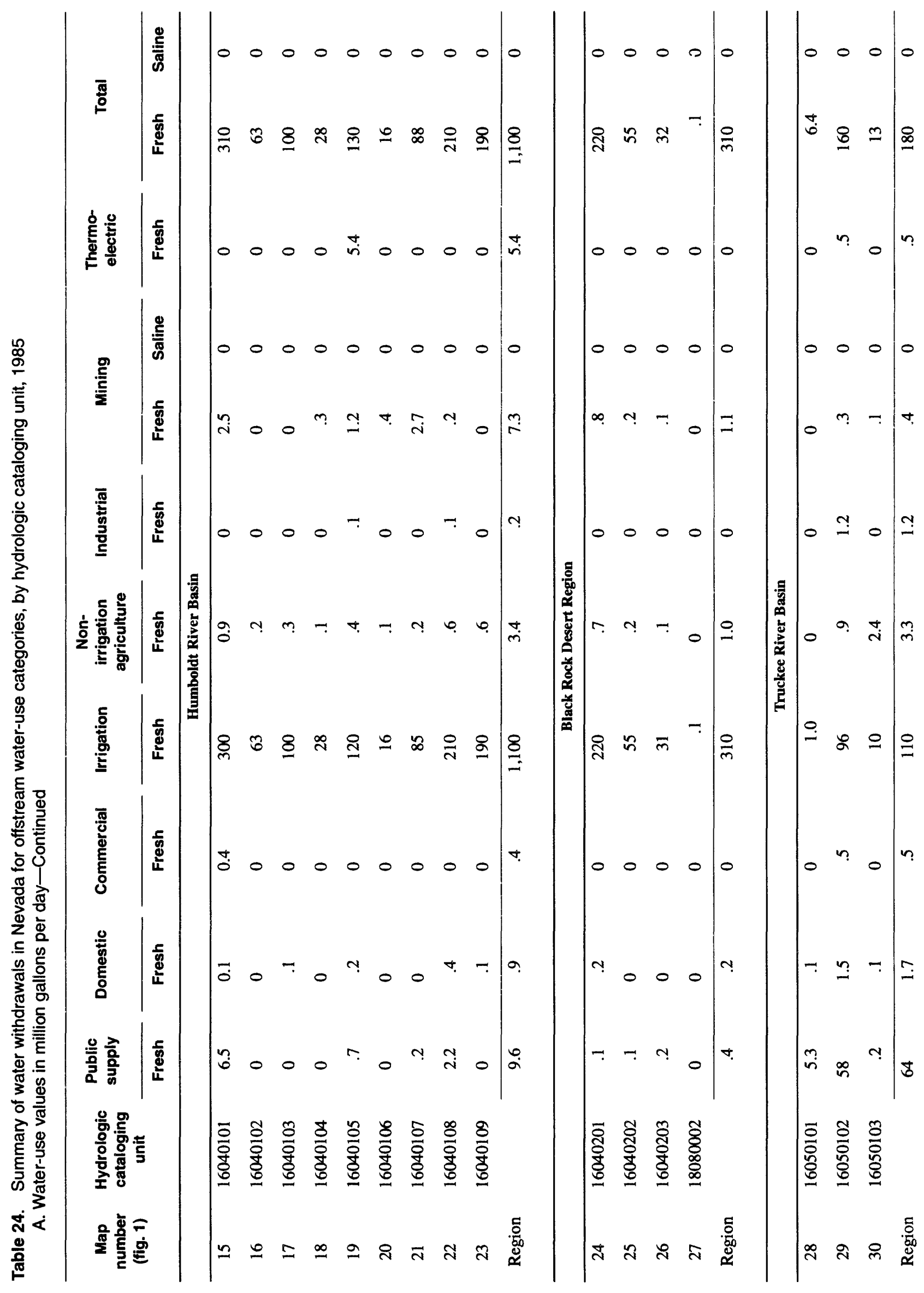




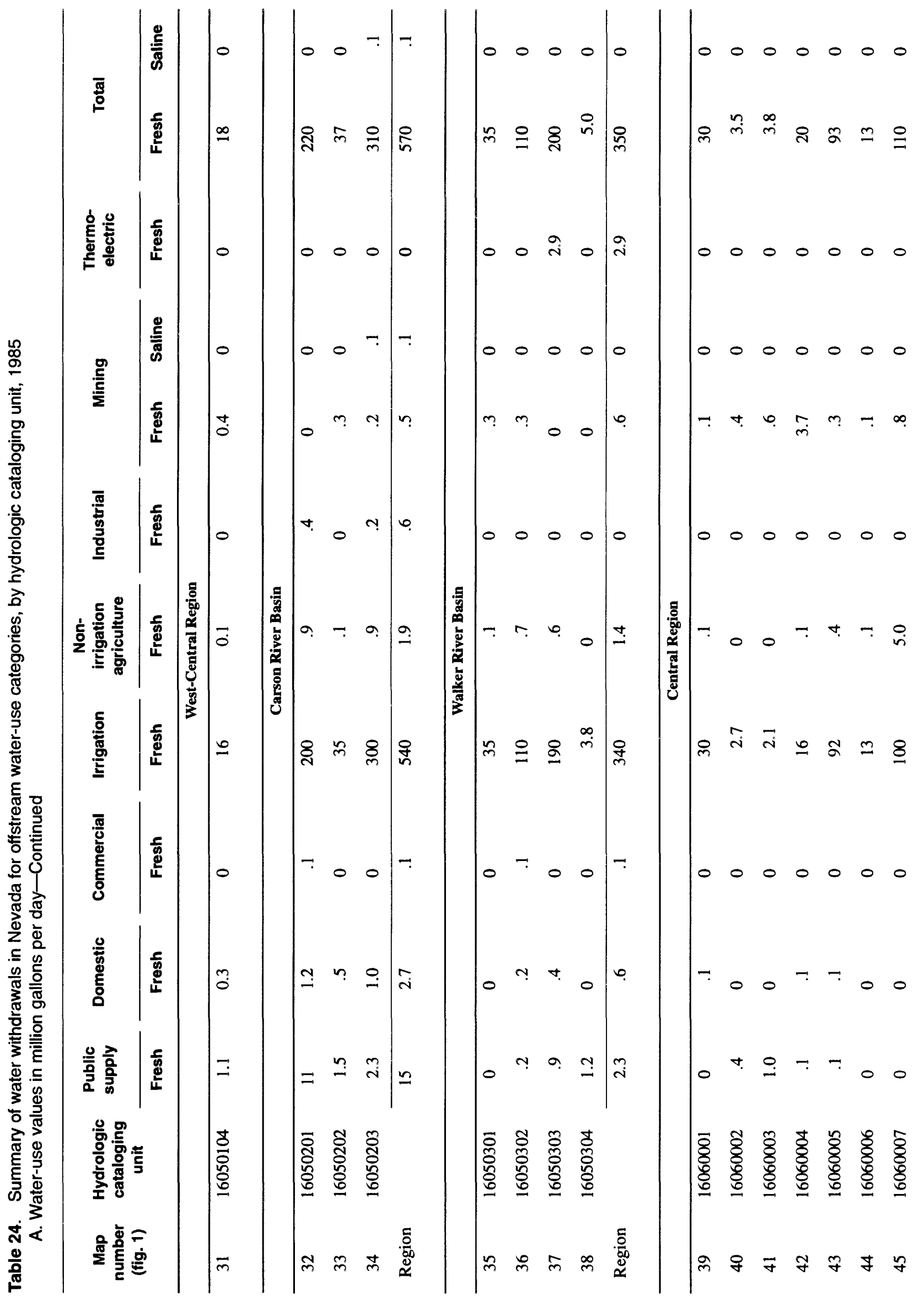




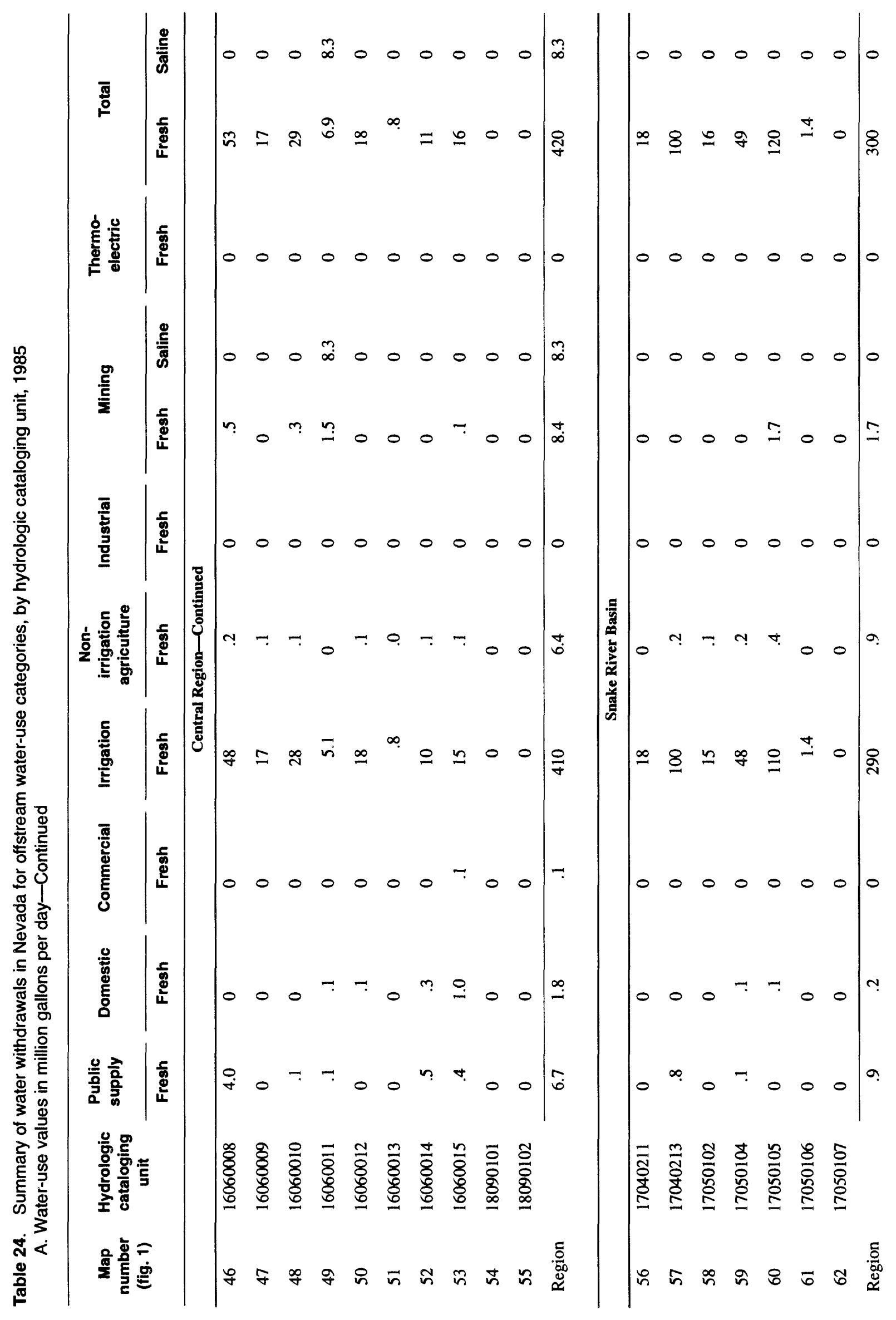




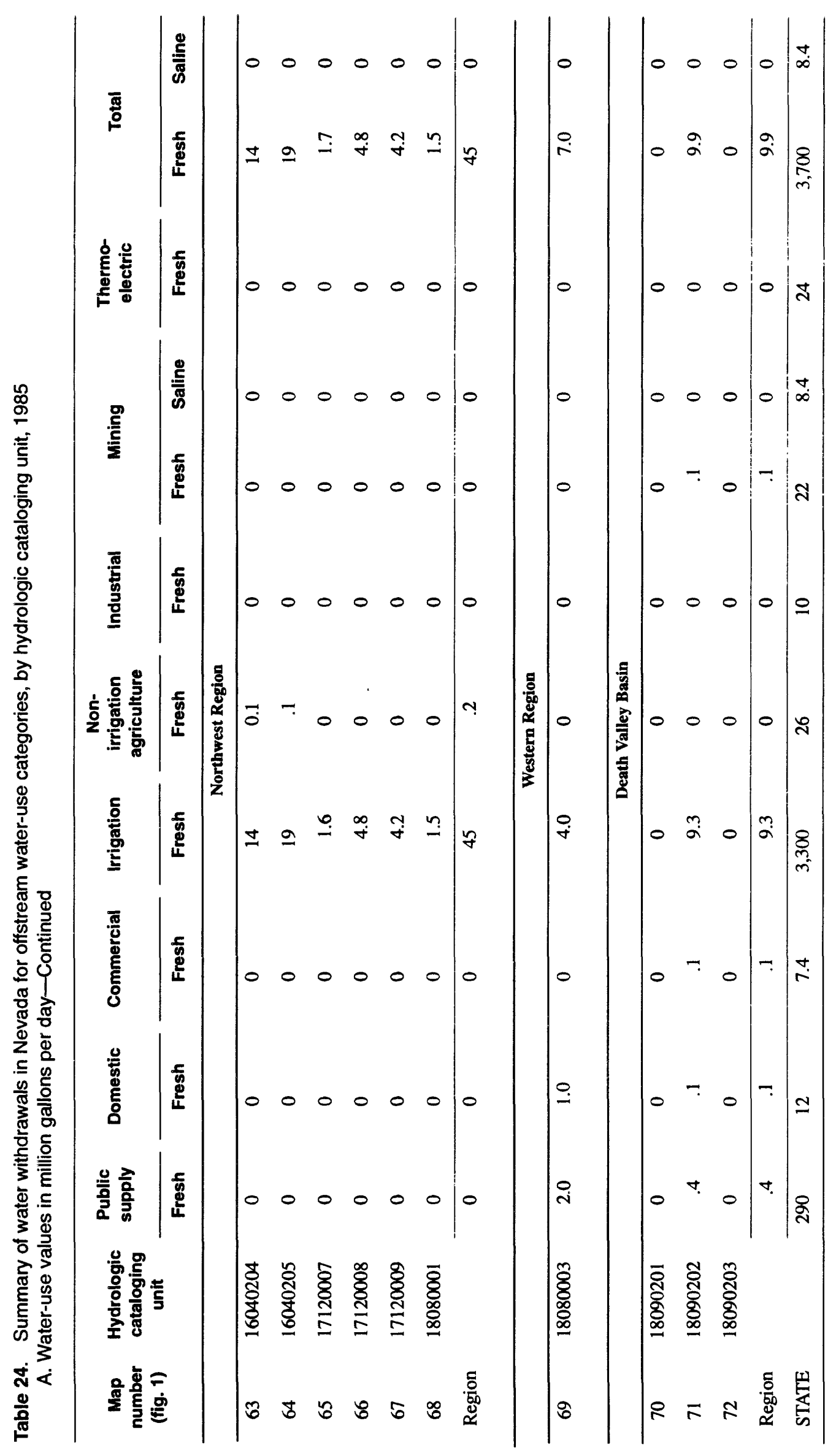




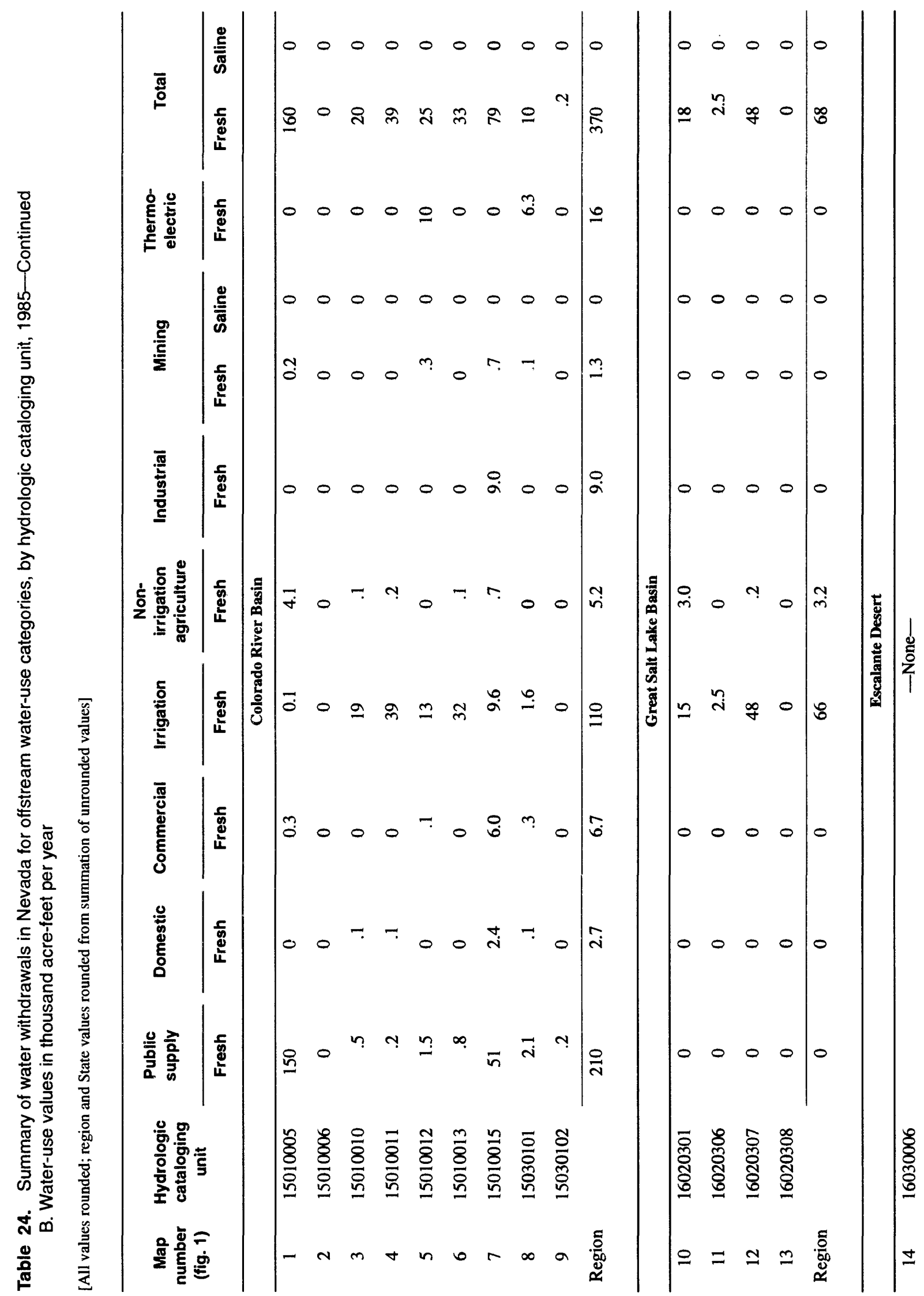




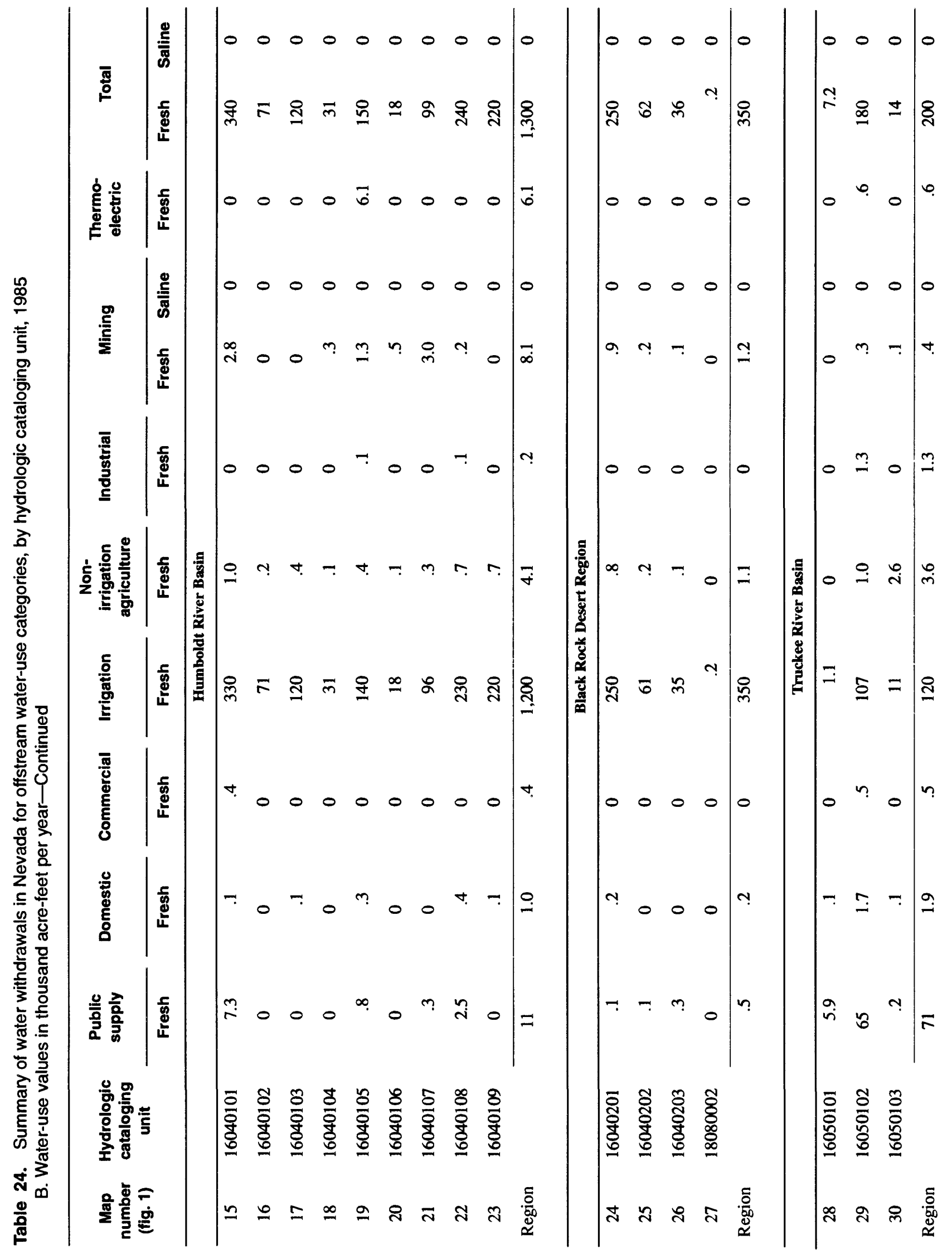




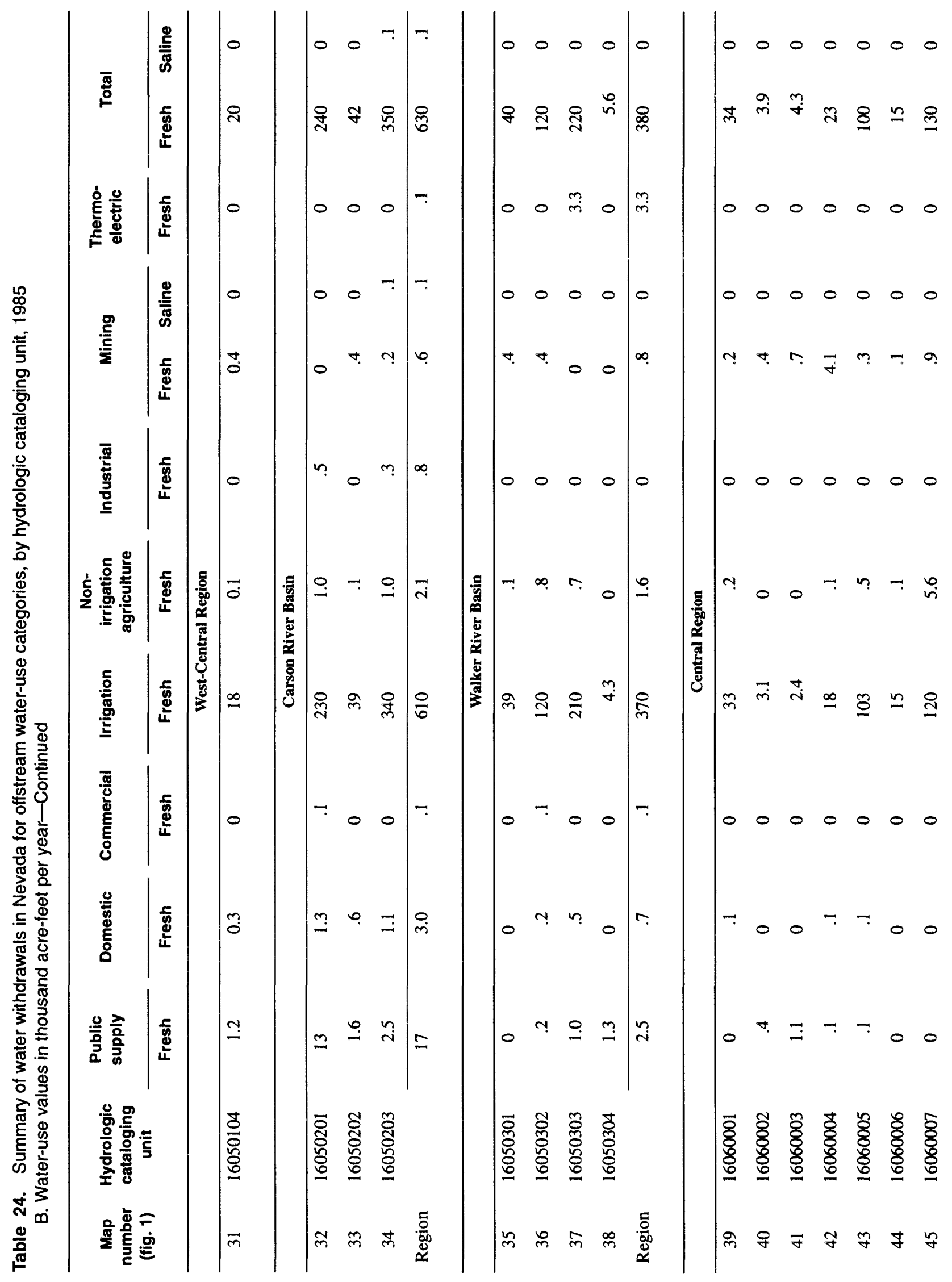




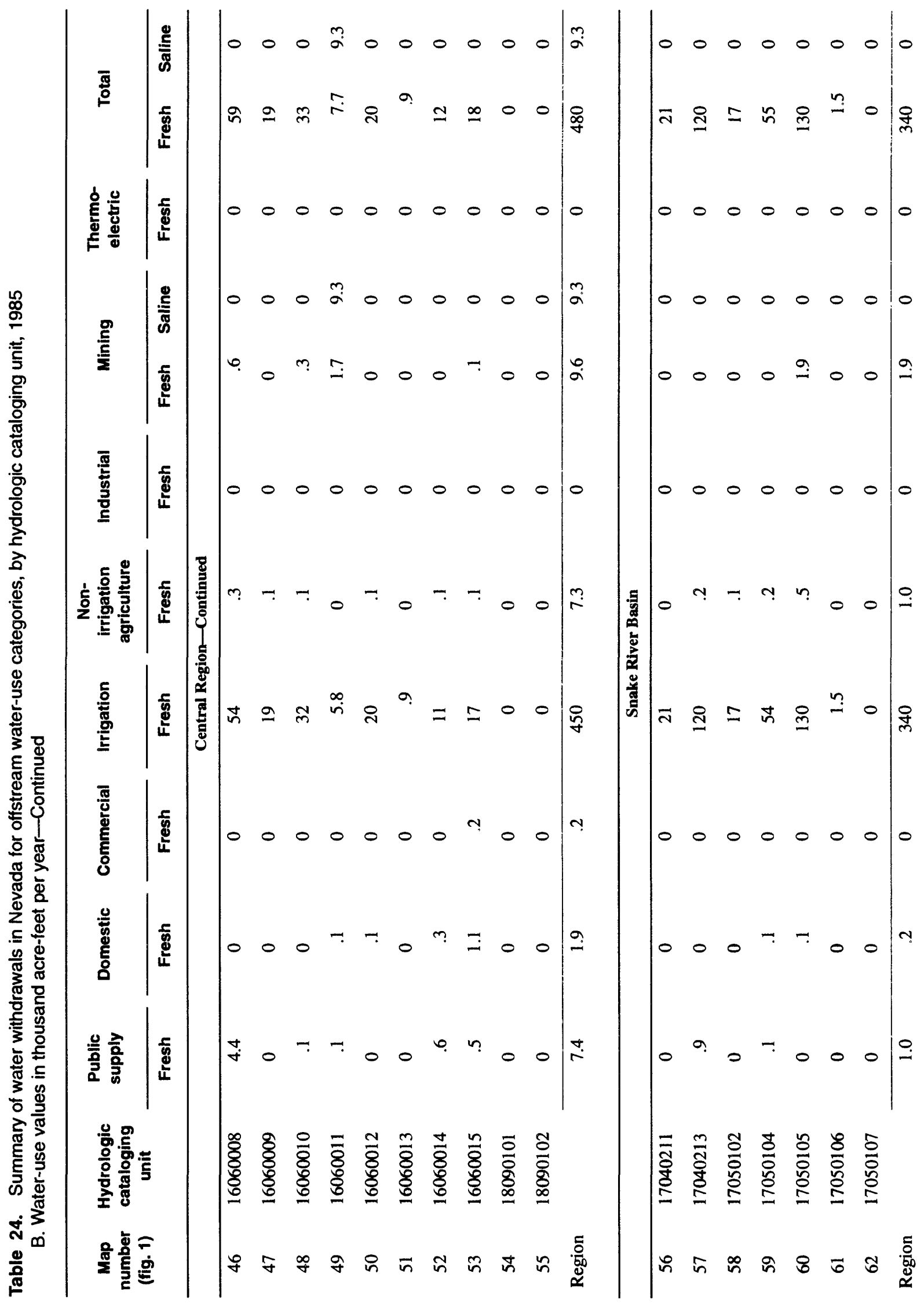




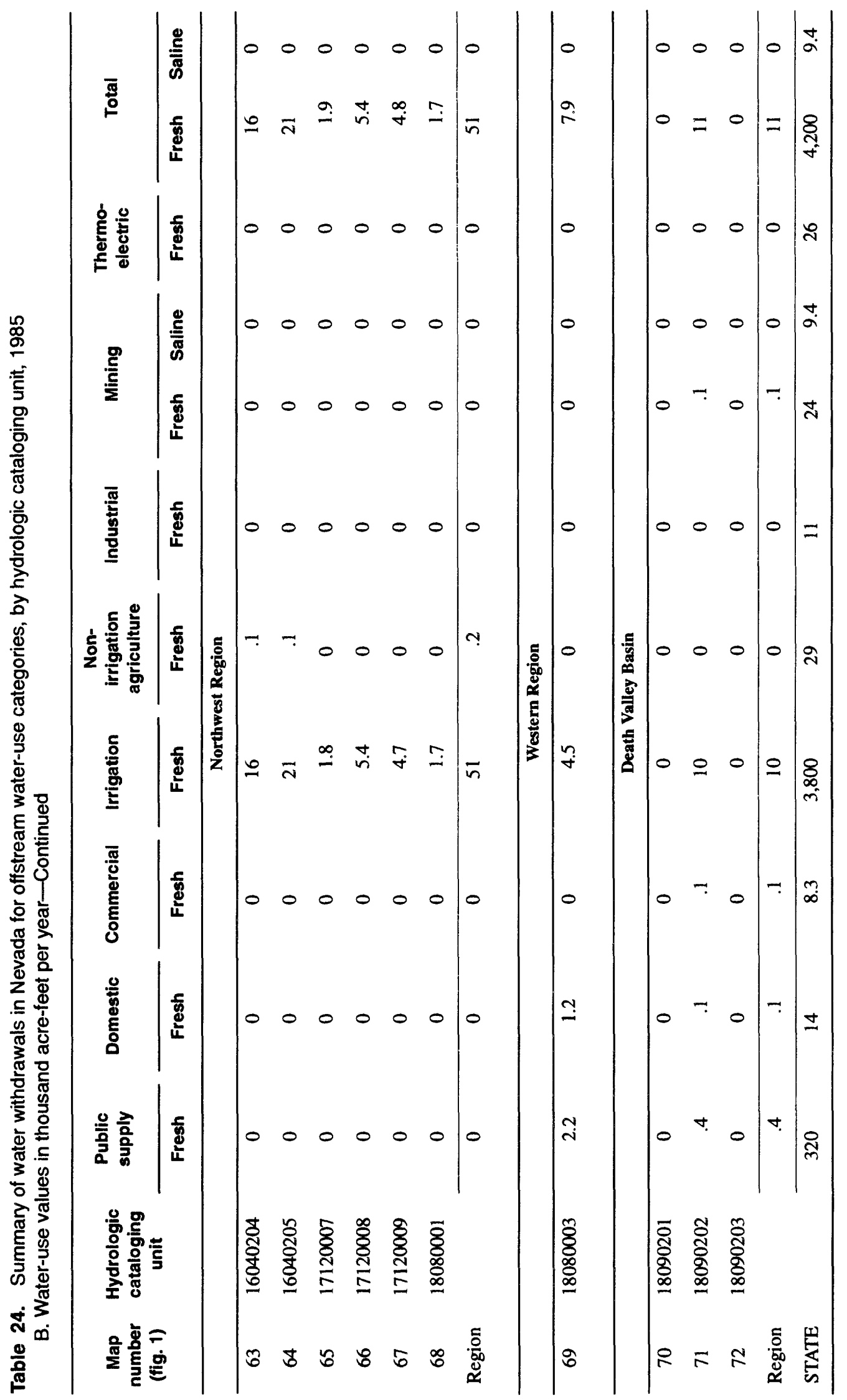




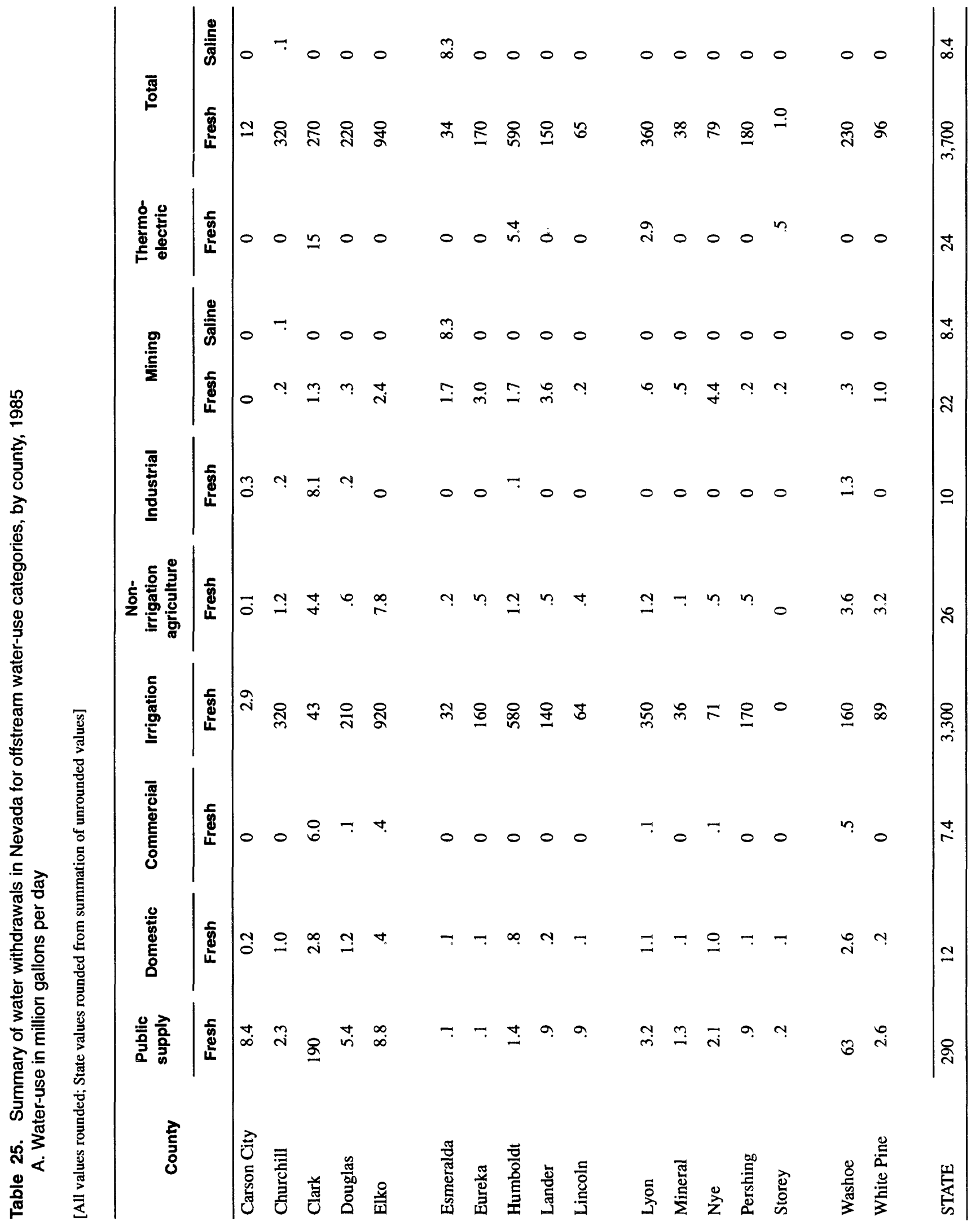




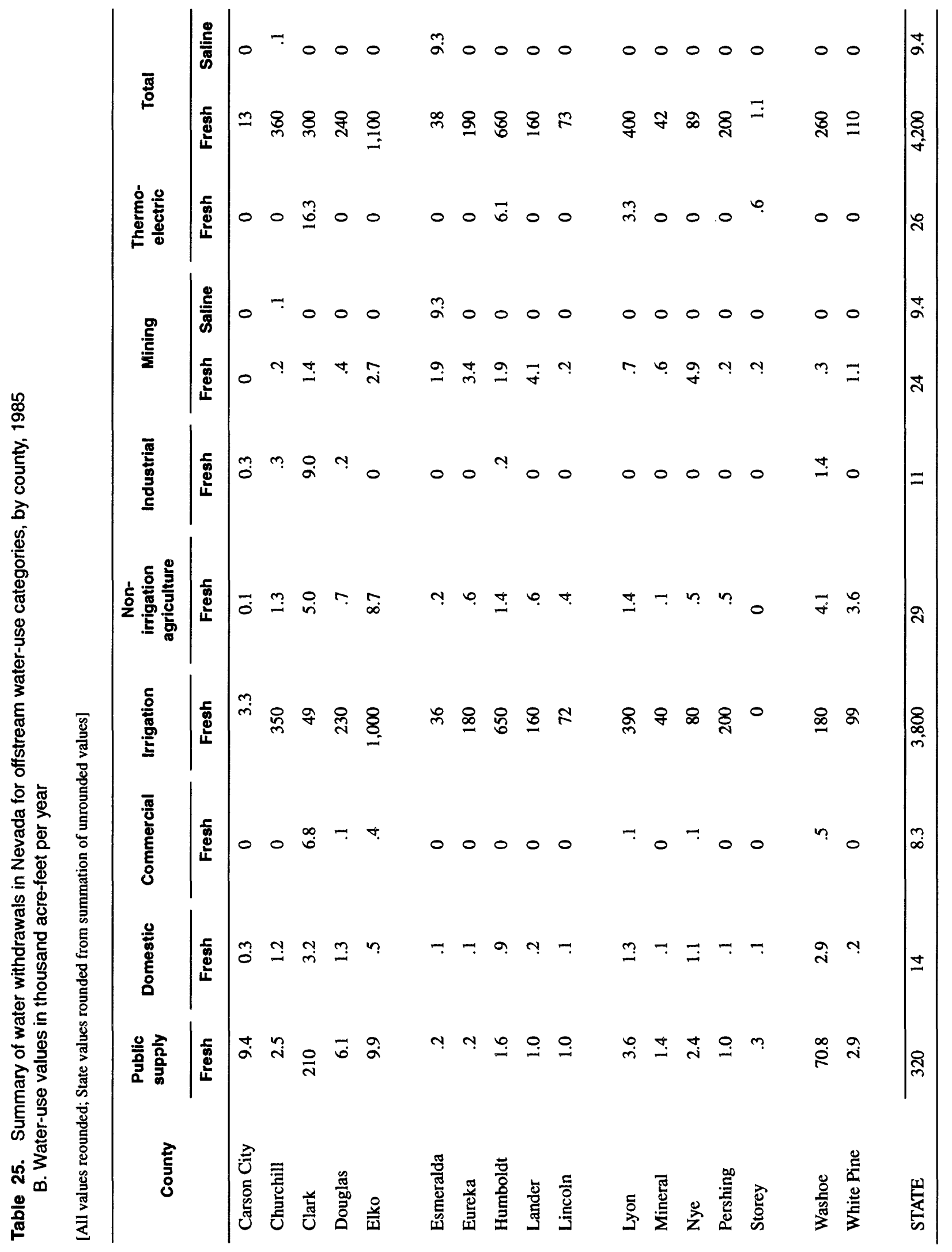




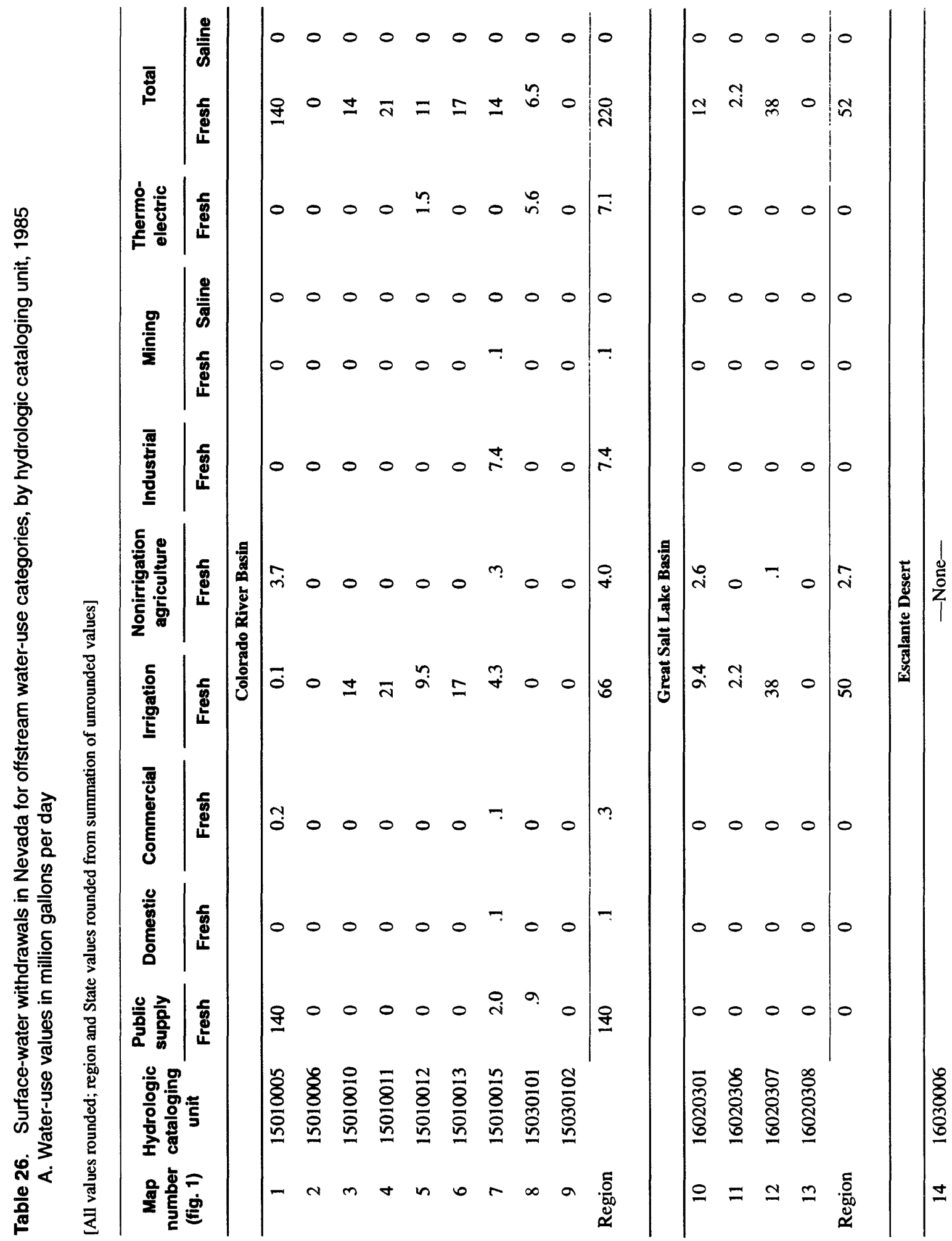




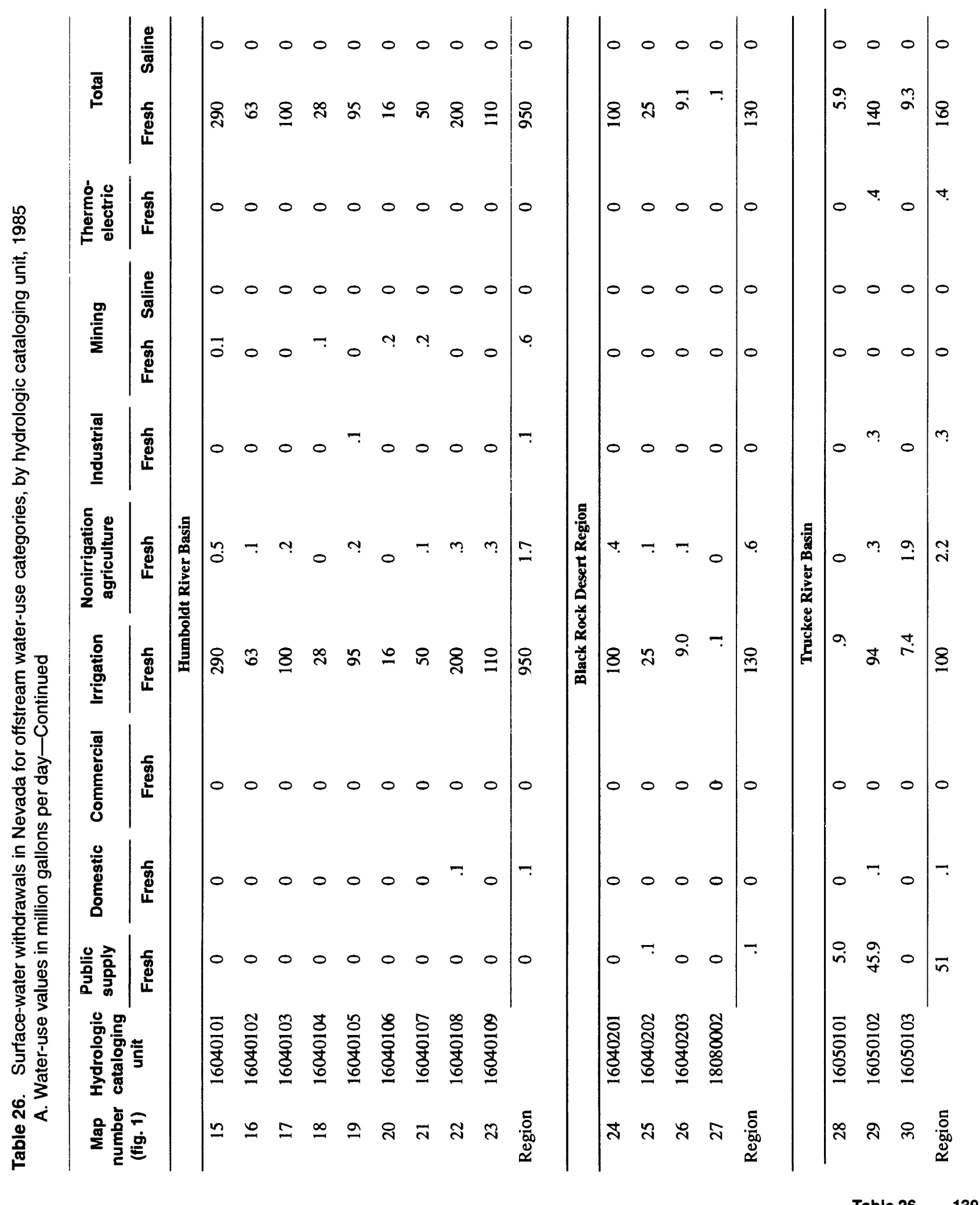




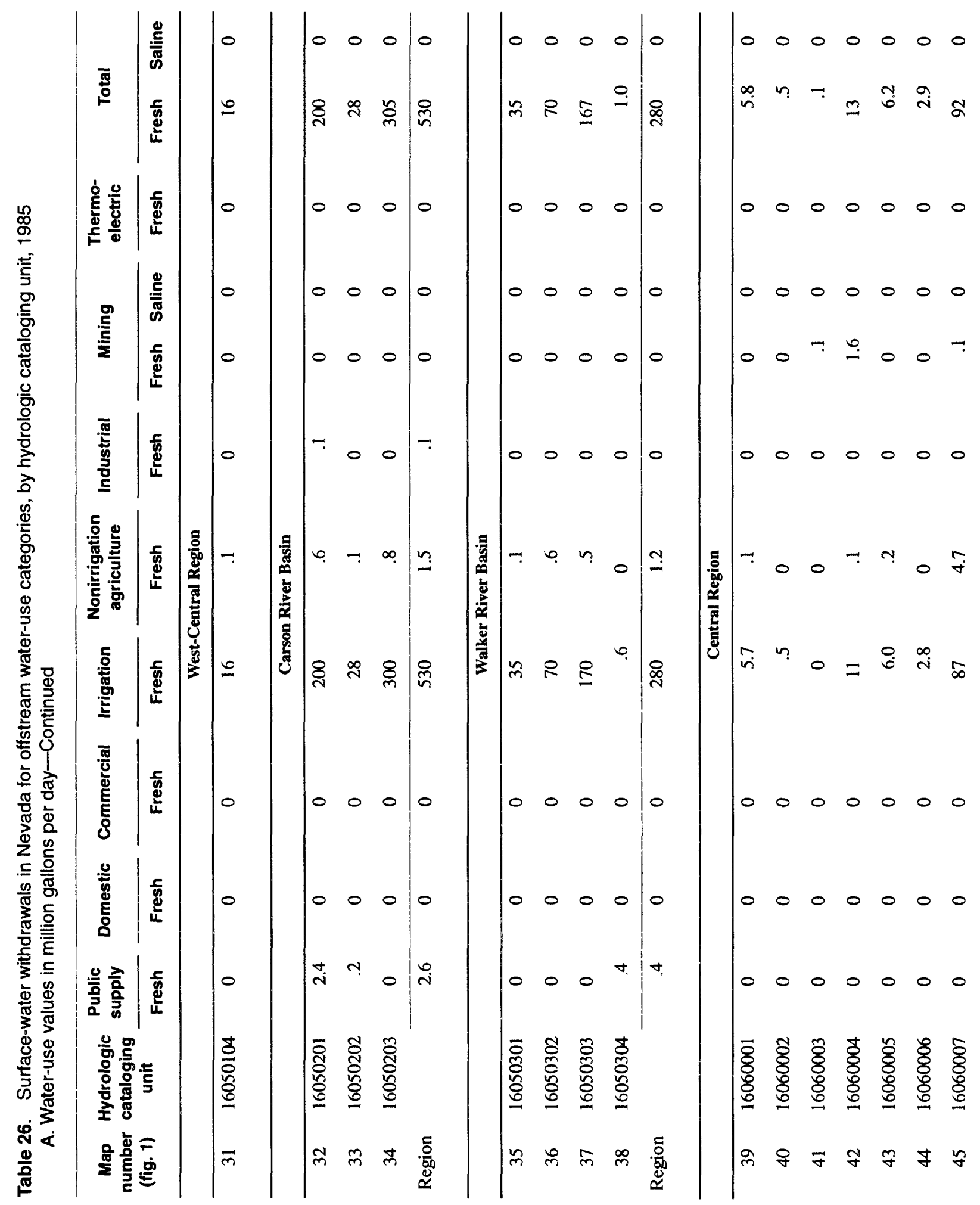




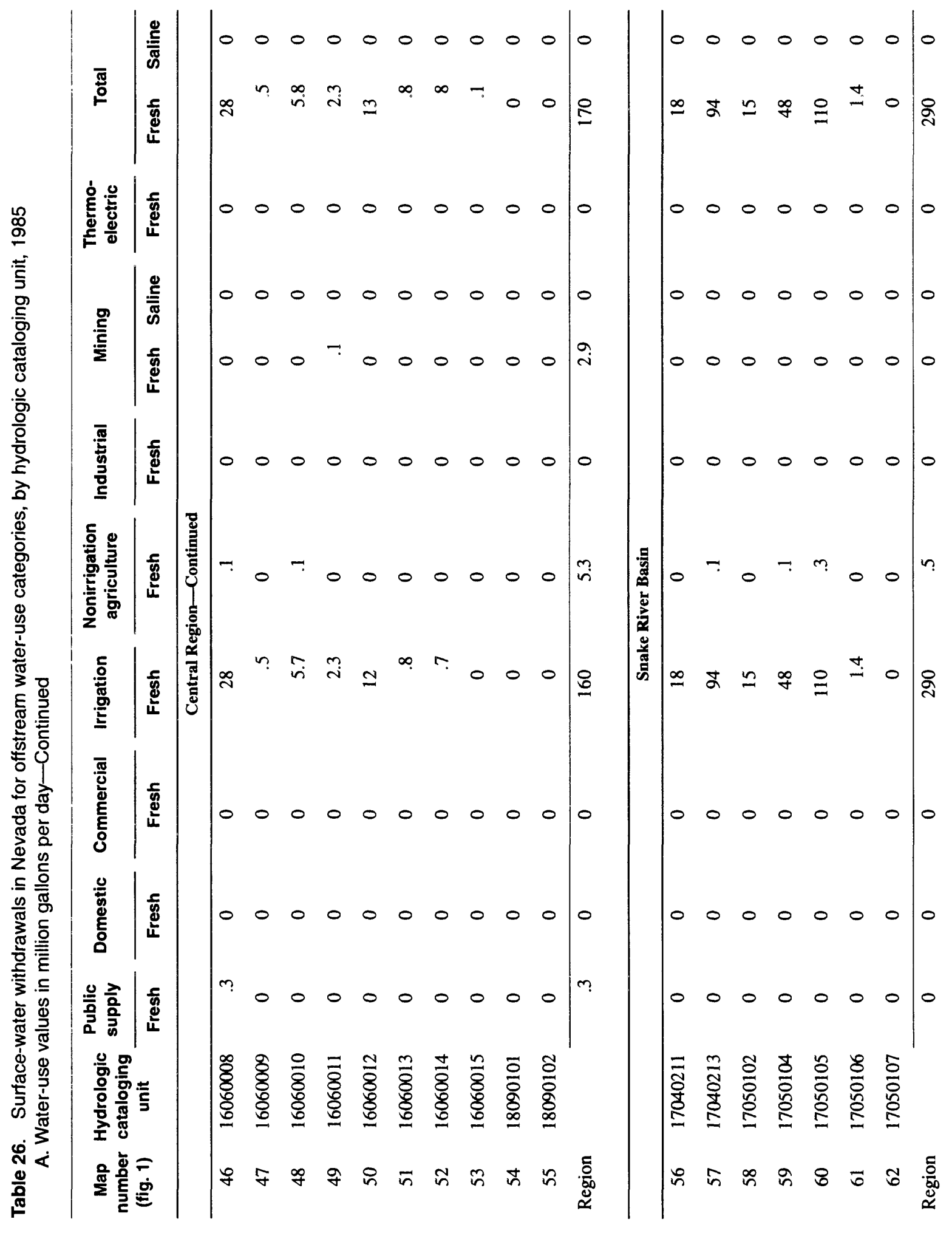




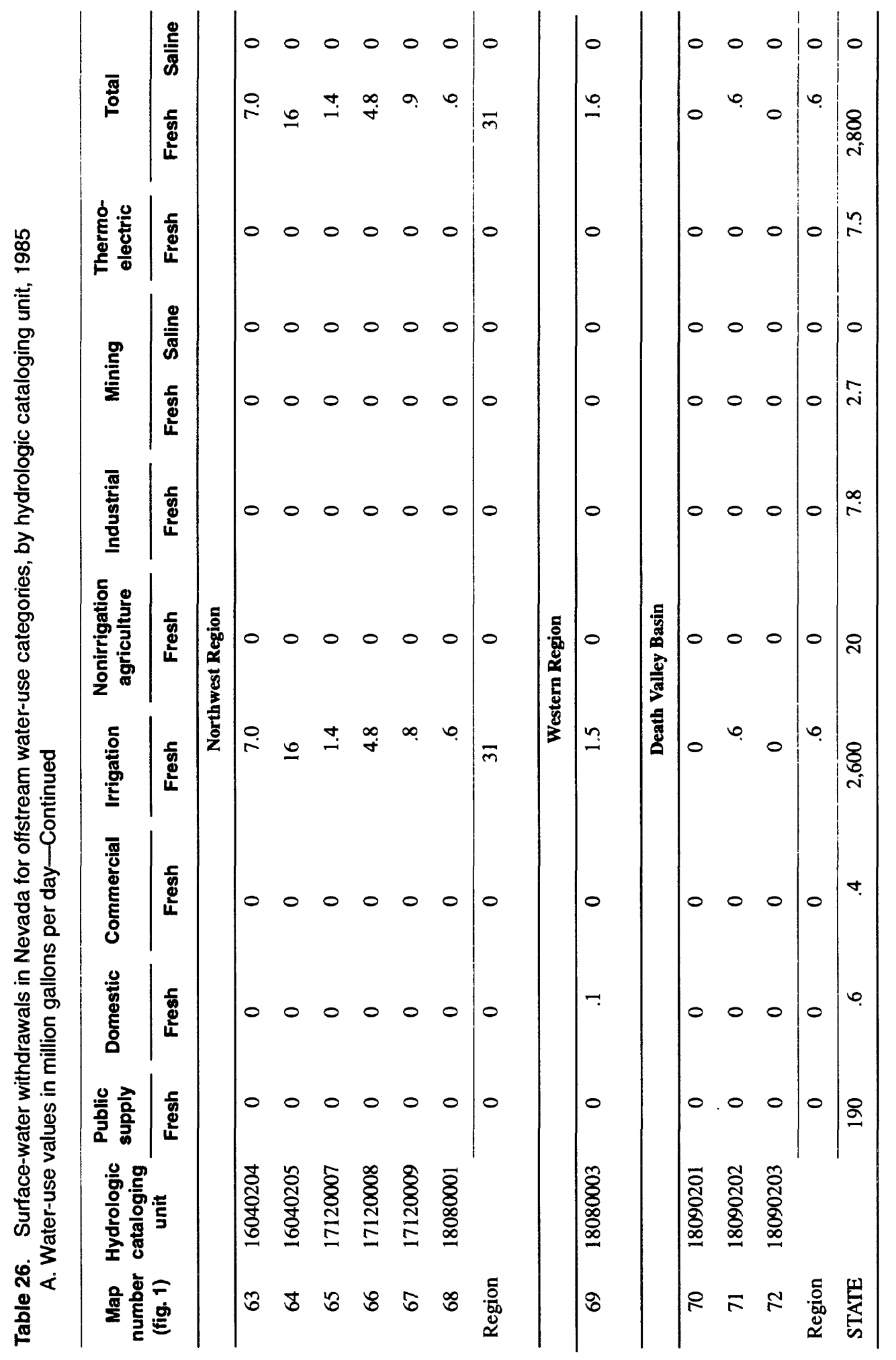




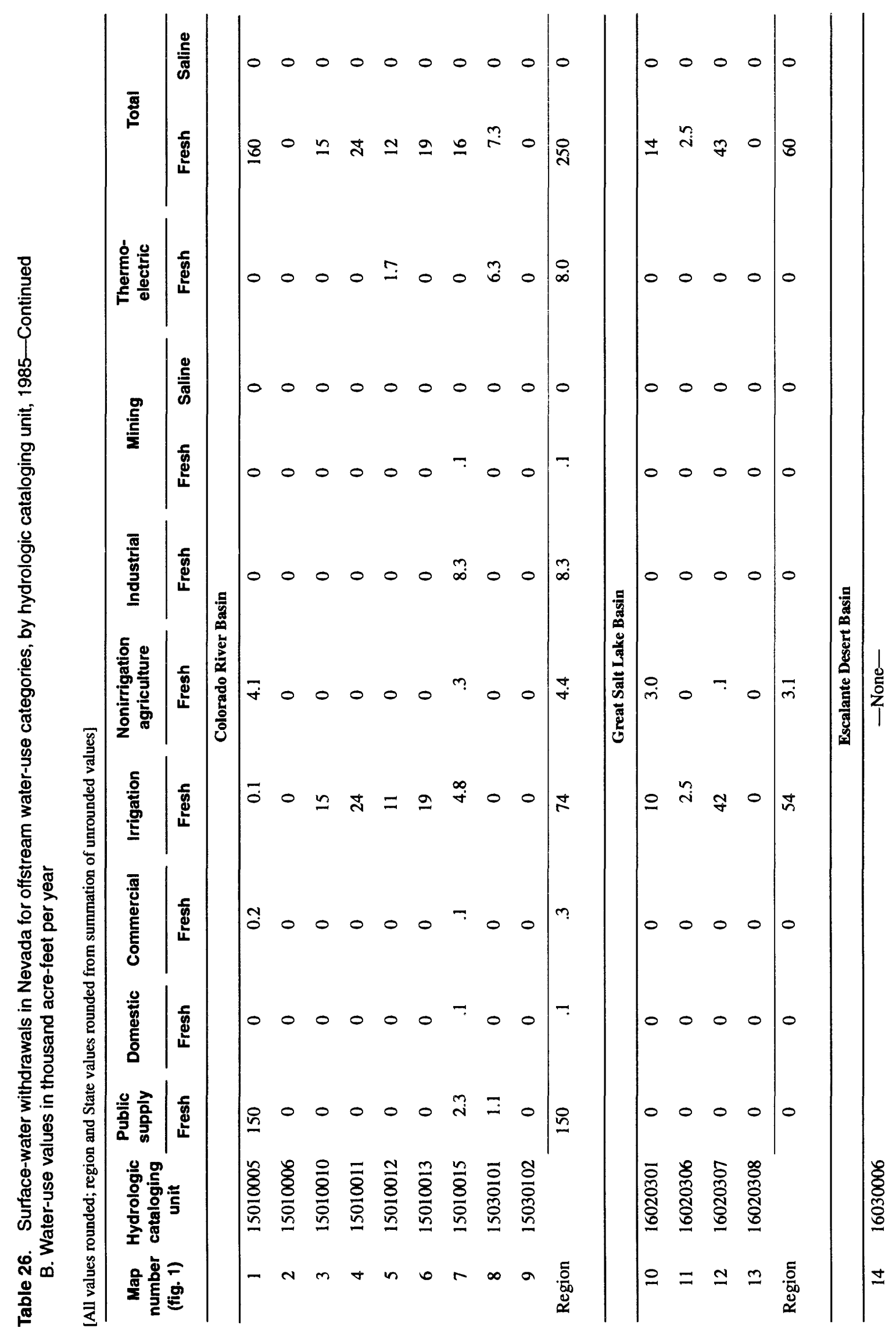




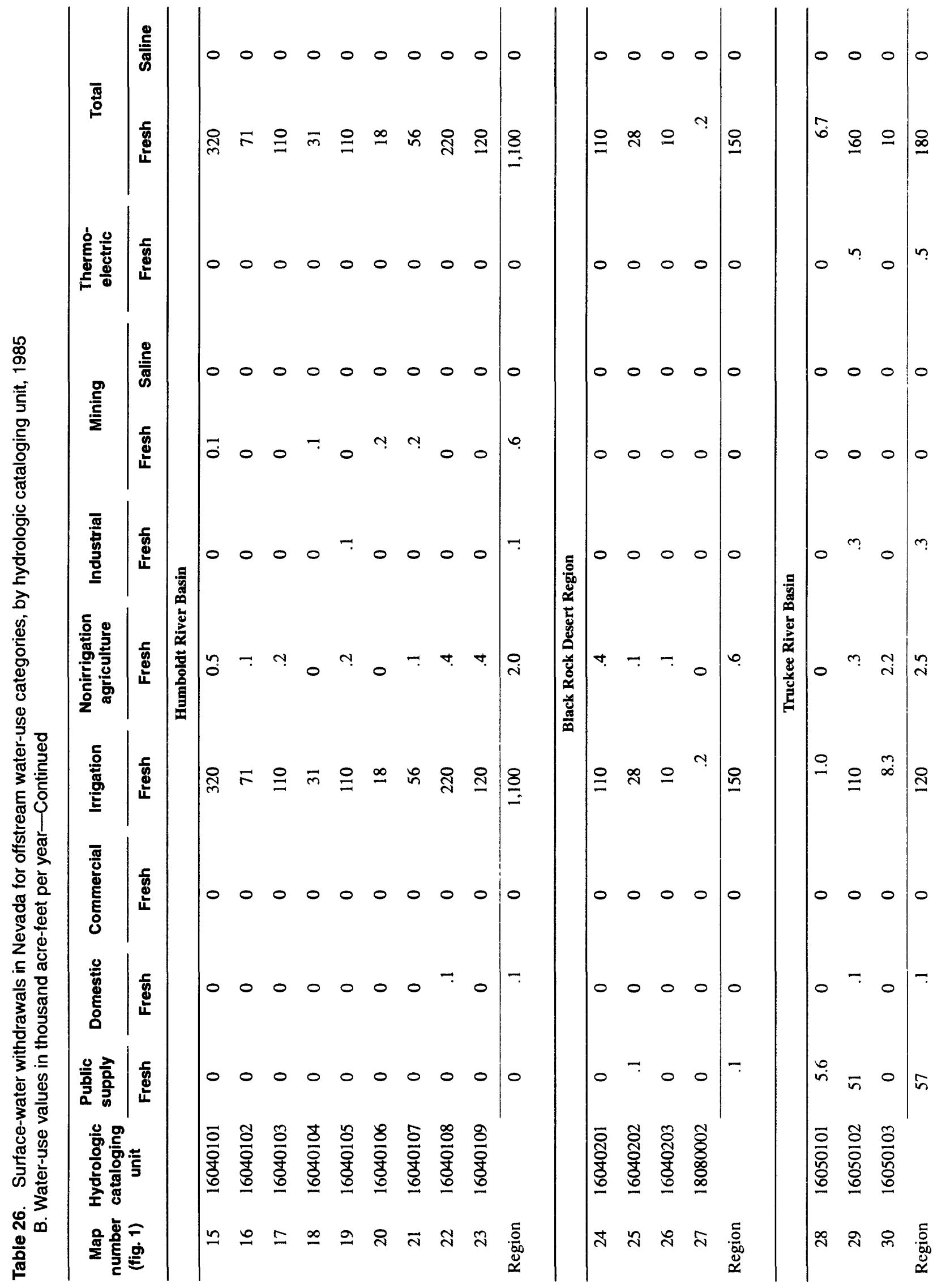




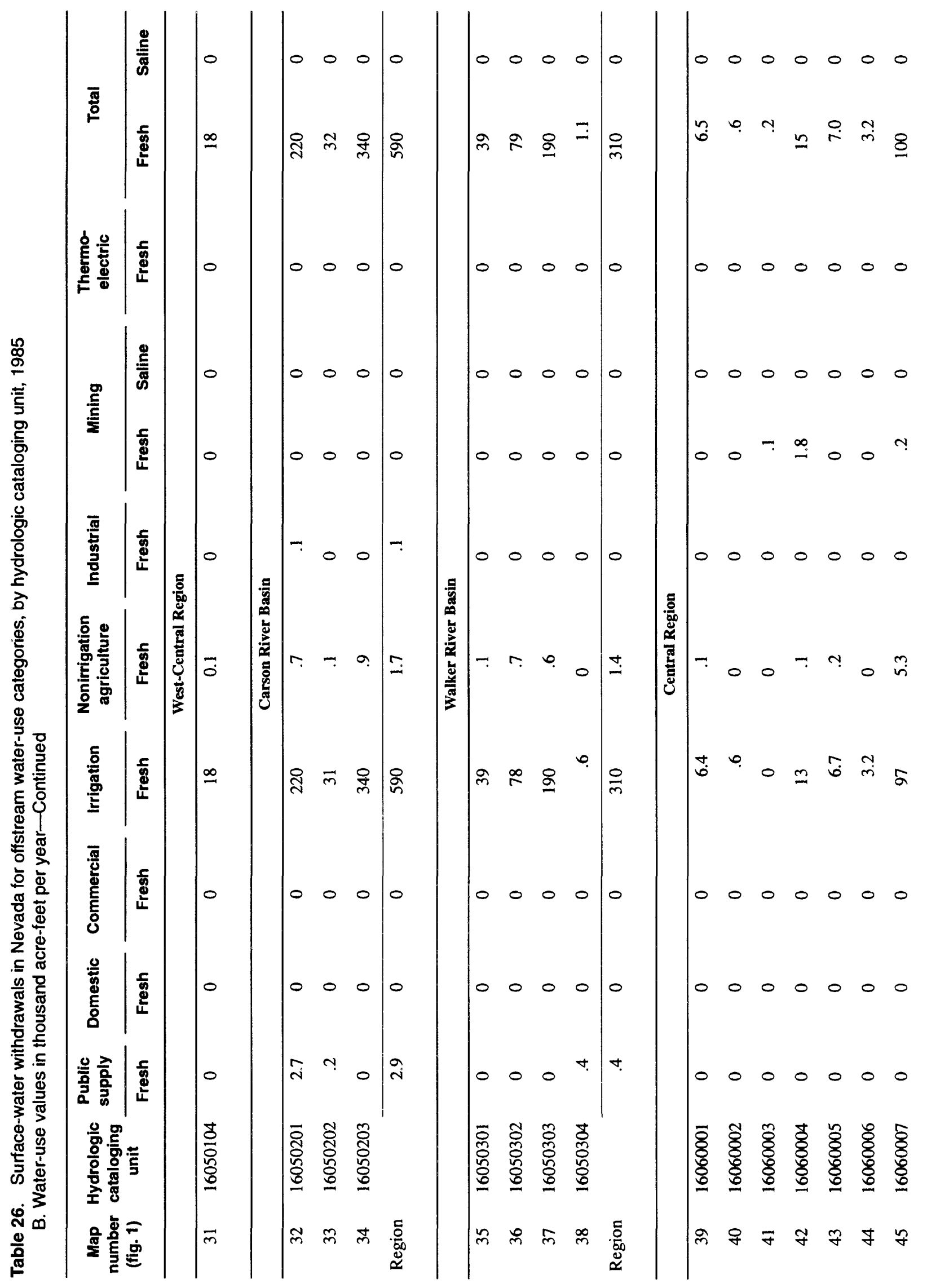




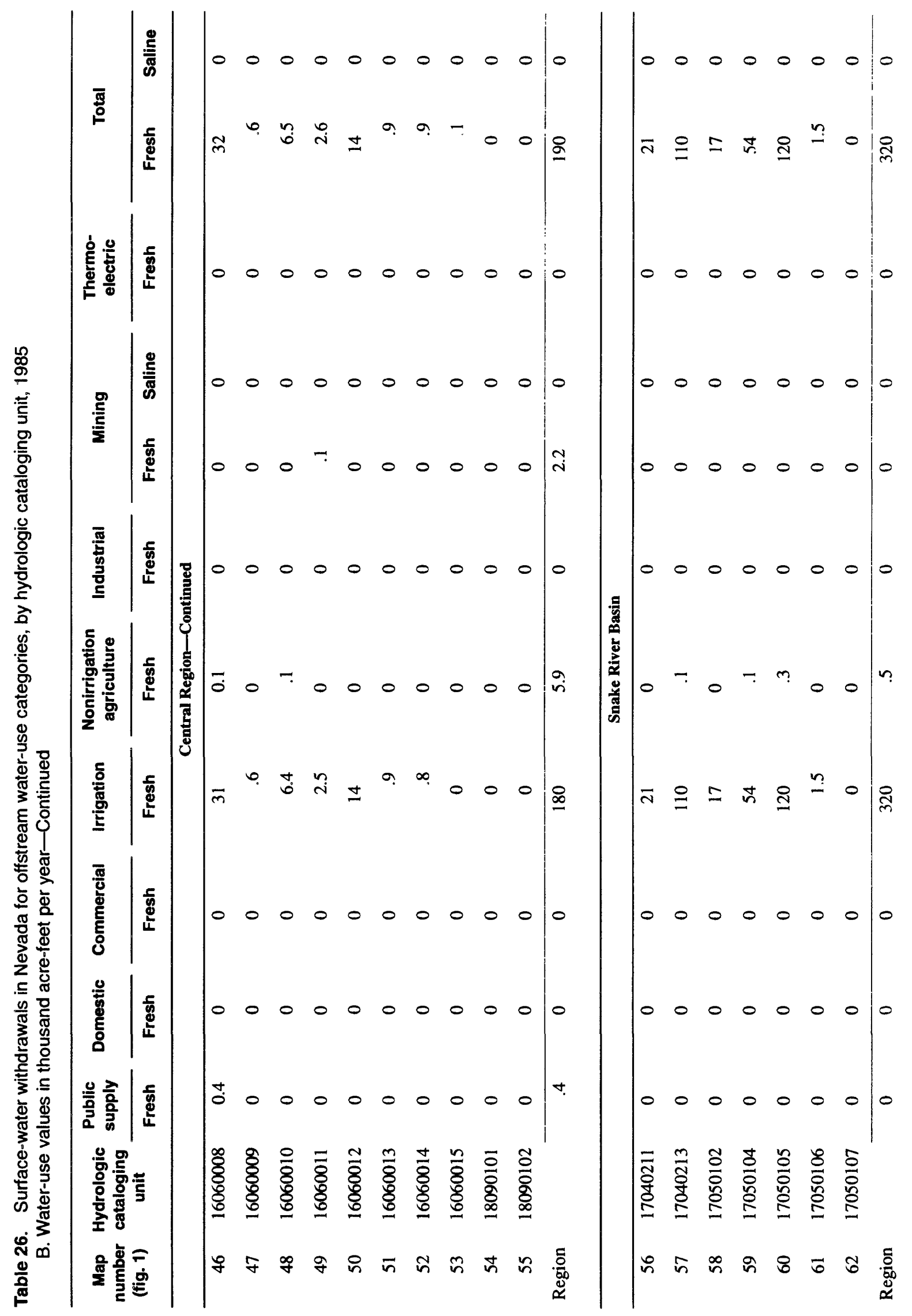




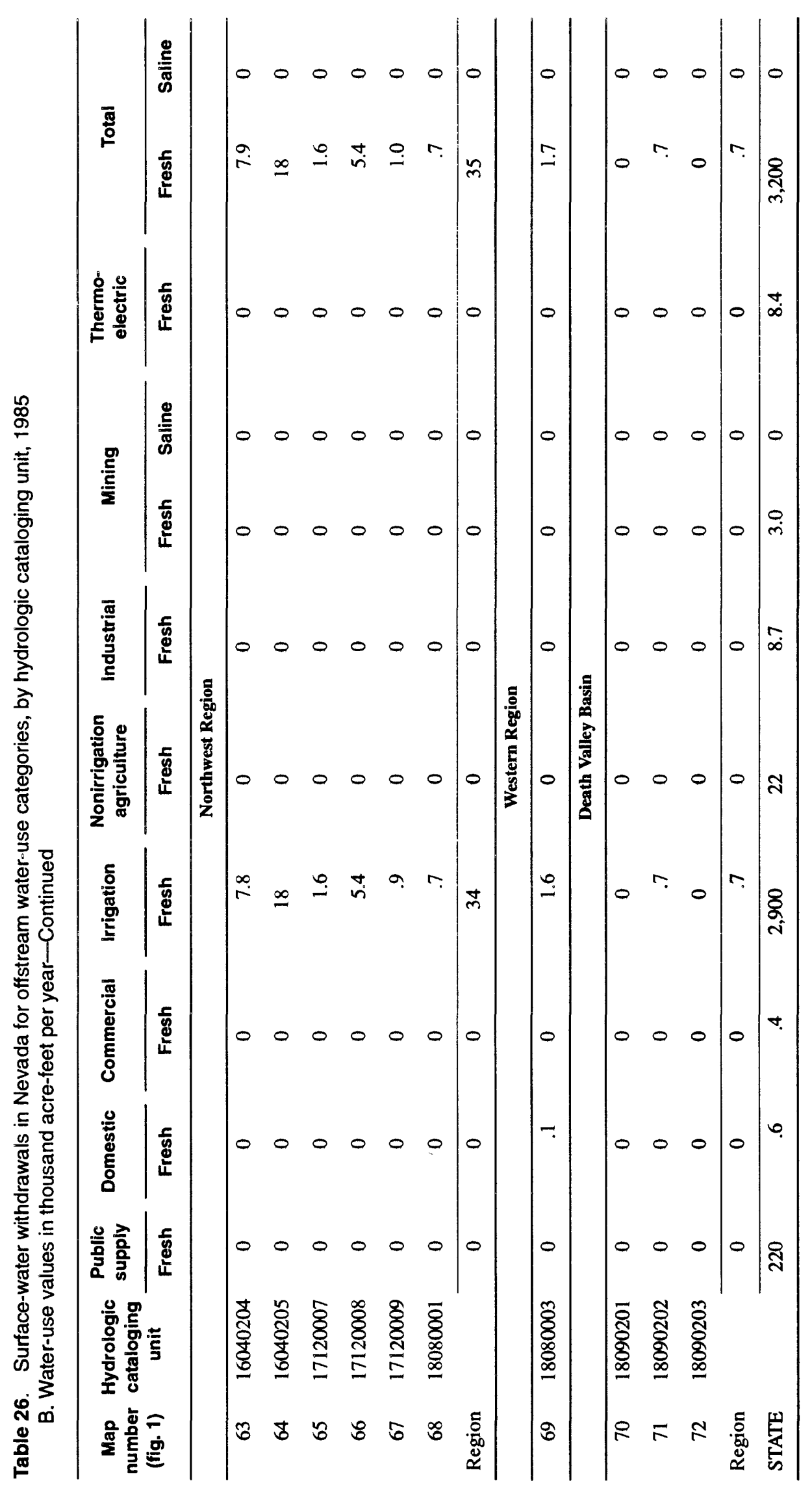


Table 27. Surface-water withdrawals in Nevada for offstream water-use categories, by county, 1985

A. Water-use values in million gallons per day

[All values rounded; State values rounded from summation of unrounded values]

\begin{tabular}{|c|c|c|c|c|c|c|c|c|c|c|c|}
\hline \multirow{2}{*}{ County } & \multirow{2}{*}{$\begin{array}{c}\begin{array}{c}\text { Public } \\
\text { supply }\end{array} \\
\text { Fresh }\end{array}$} & \multirow{2}{*}{$\begin{array}{c}\text { Domestic } \\
\text { Fresh }\end{array}$} & \multirow{2}{*}{$\frac{\text { Commercial }}{\text { Fresh }}$} & \multirow{2}{*}{$\frac{\text { Irrigation }}{\text { Fresh }}$} & \multirow{2}{*}{$\begin{array}{c}\begin{array}{c}\text { Nonirrigation } \\
\text { agriculture }\end{array} \\
\text { Fresh }\end{array}$} & \multirow{2}{*}{$\frac{\text { Industrial }}{\text { Fresh }}$} & \multicolumn{2}{|c|}{ Mining } & \multirow{2}{*}{$\begin{array}{c}\text { Thermo- } \\
\text { electric }\end{array}$} & \multicolumn{2}{|c|}{ Total } \\
\hline & & & & & & & Fresh & Saline & & Fresh & Saline \\
\hline Carson City & 2.4 & 0 & 0 & 2.9 & 0 & 0.1 & 0 & 0 & 0 & 5.4 & 0 \\
\hline Churchill & 0 & 0 & 0 & 300 & .7 & 0 & 0 & 0 & 0 & 310 & 0 \\
\hline Clark & 140 & .1 & .4 & 32 & 3.9 & 7.4 & .1 & 0 & 7.1 & 190 & 0 \\
\hline Douglas & 1.9 & 0 & 0 & 200 & .4 & 0 & 0 & 0 & 0 & 200 & 0 \\
\hline Elko & .1 & .1 & 0 & 870 & 6.5 & 0 & .2 & 0 & 0 & 880 & 0 \\
\hline Esmeralda & 0 & 0 & 0 & 6.5 & 0 & 0 & .1 & 0 & 0 & 6.5 & 0 \\
\hline Eureka & 0 & 0 & 0 & 60 & .3 & 0 & .2 & 0 & 0 & 60 & 0 \\
\hline Humboldt & 0 & 0 & 0 & 330 & .8 & .1 & 0 & 0 & 0 & 330 & 0 \\
\hline Lander & 0 & .1 & 0 & 93 & .3 & 0 & .2 & 0 & 0 & 94 & 0 \\
\hline Lincoln & 0 & 0 & 0 & 26 & .2 & 0 & 0 & 0 & 0 & 26 & 0 \\
\hline Lyon & 0 & 0 & 0 & 280 & 1.1 & 0 & 0 & 0 & 0 & 280 & 0 \\
\hline Mineral & .4 & 0 & 0 & 32 & 0 & 0 & 0 & 0 & 0 & 32 & 0 \\
\hline Nye & 0 & .1 & 0 & 35 & .3 & 0 & 1.7 & 0 & 0 & 37 & 0 \\
\hline Pershing & .1 & 0 & 0 & 160 & .4 & 0 & 0 & 0 & 0 & 160 & 0 \\
\hline Storey & .2 & 0 & 0 & 0 & 0 & 0 & 0 & 0 & .4 & .6 & 0 \\
\hline Washoe & 49 & .1 & 0 & 130 & 2.4 & .3 & 0 & 0 & 0 & 180 & 0 \\
\hline White Pine & .3 & 0 & 0 & 47 & 2.9 & 0 & .2 & 0 & 0 & 50.1 & 0 \\
\hline STATE & 190 & .6 & .4 & 2,600 & 20 & 7.8 & 2.7 & 0 & 7.5 & 2,800 & 0 \\
\hline
\end{tabular}


Table 27. Surface-water withdrawals in Nevada for offstream water-use categories, by county, 1985-Continued B. Water-use values in thousand acre-feet per year

[All values rounded, State values rounded from summation of unrounded values]

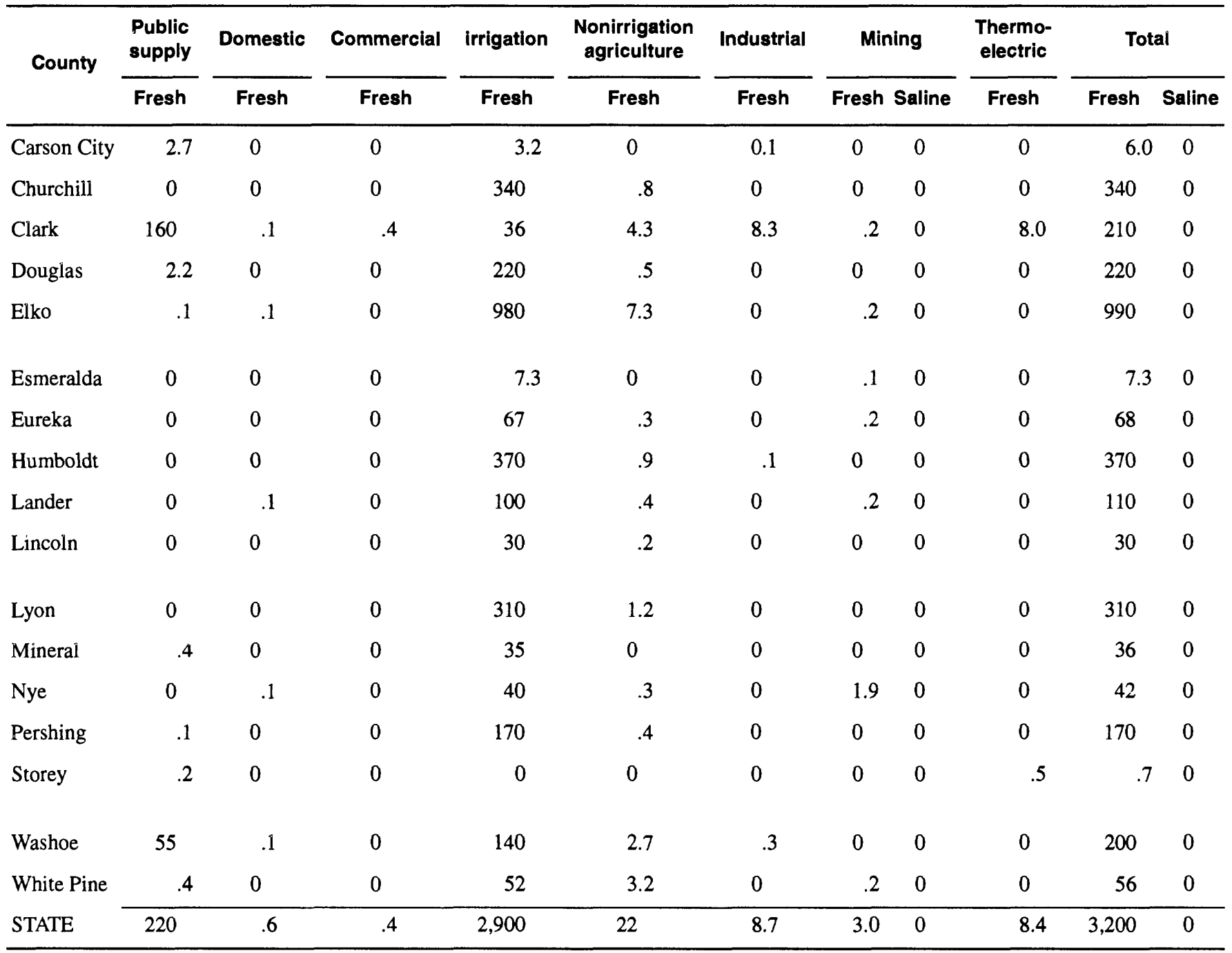




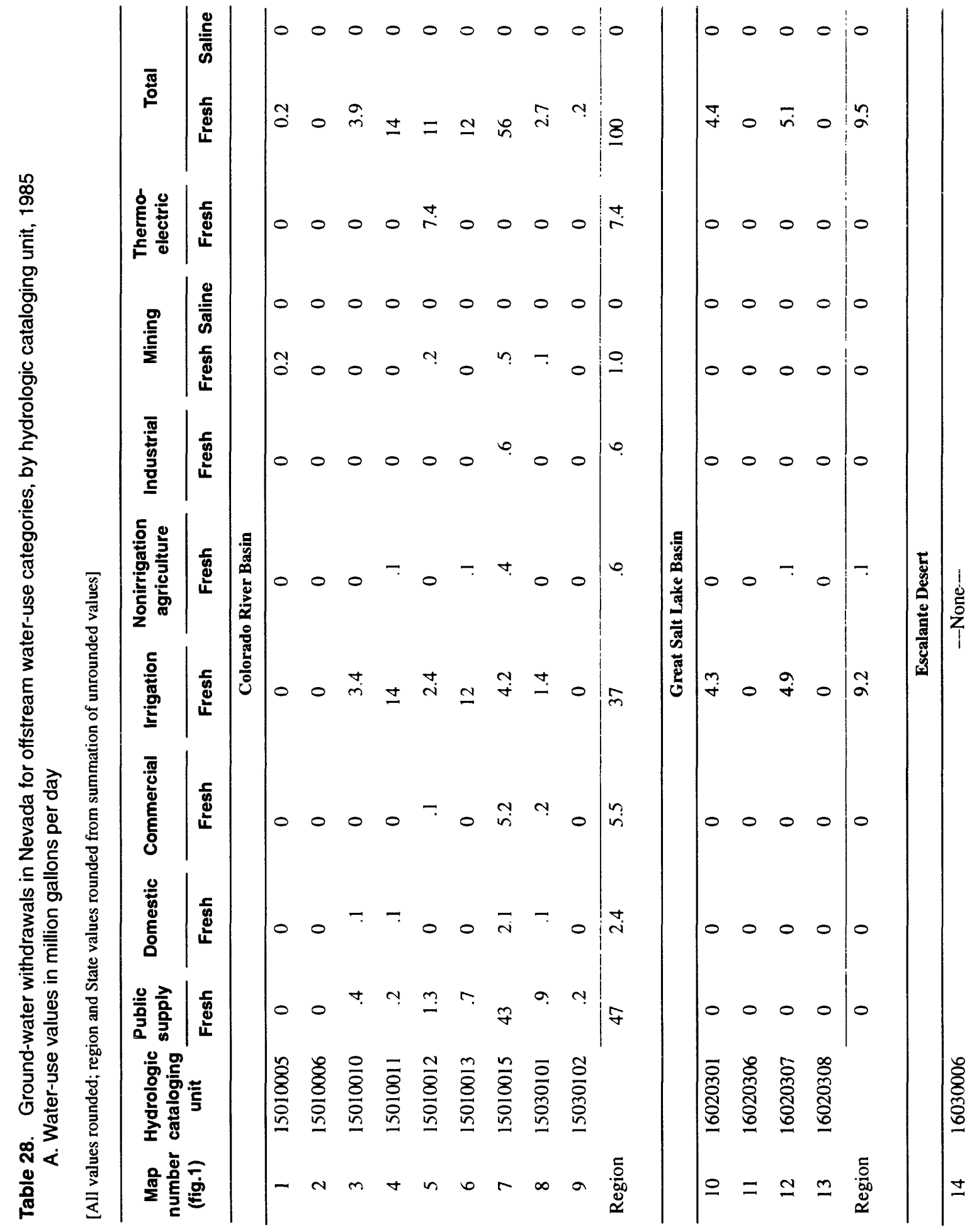




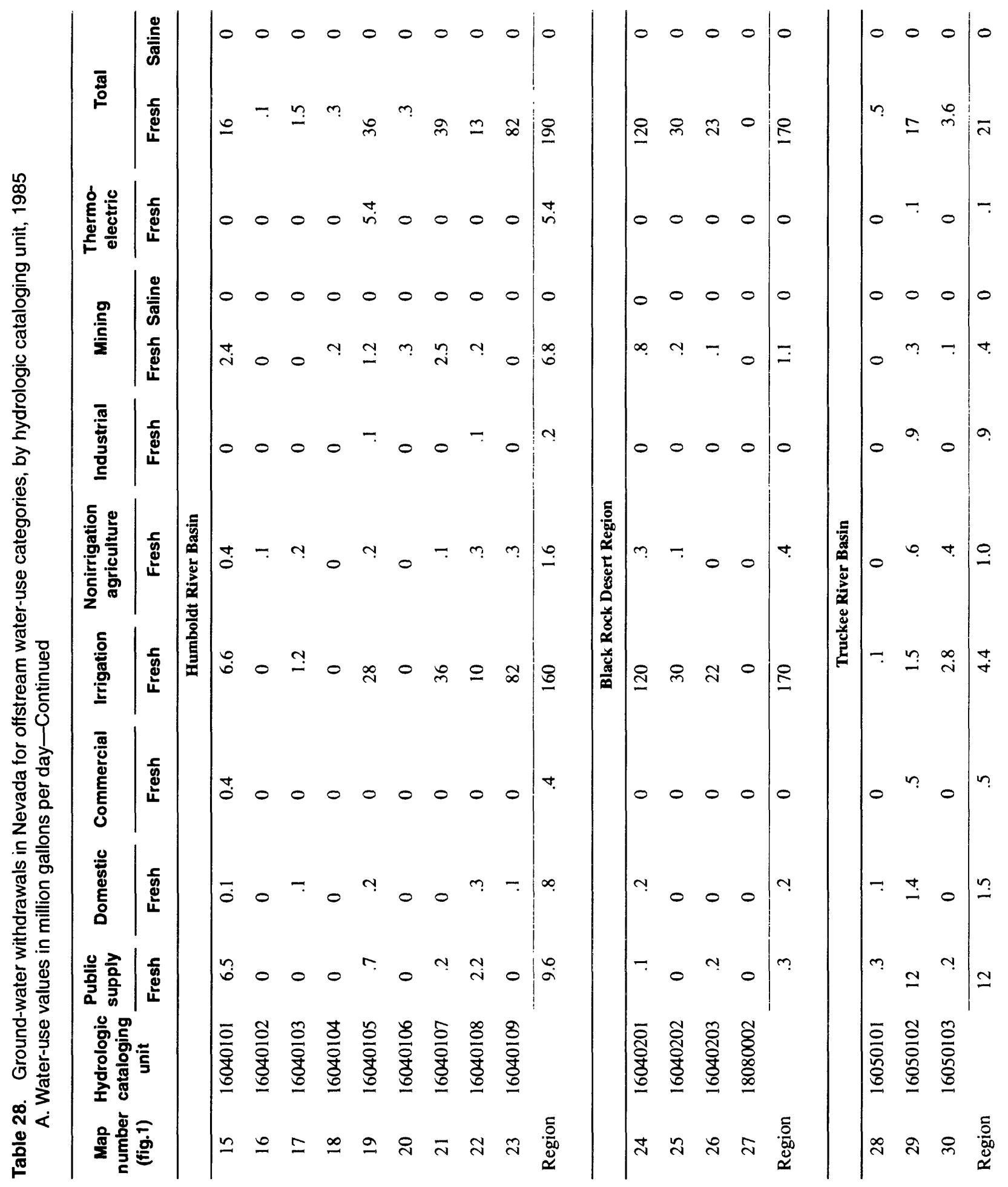




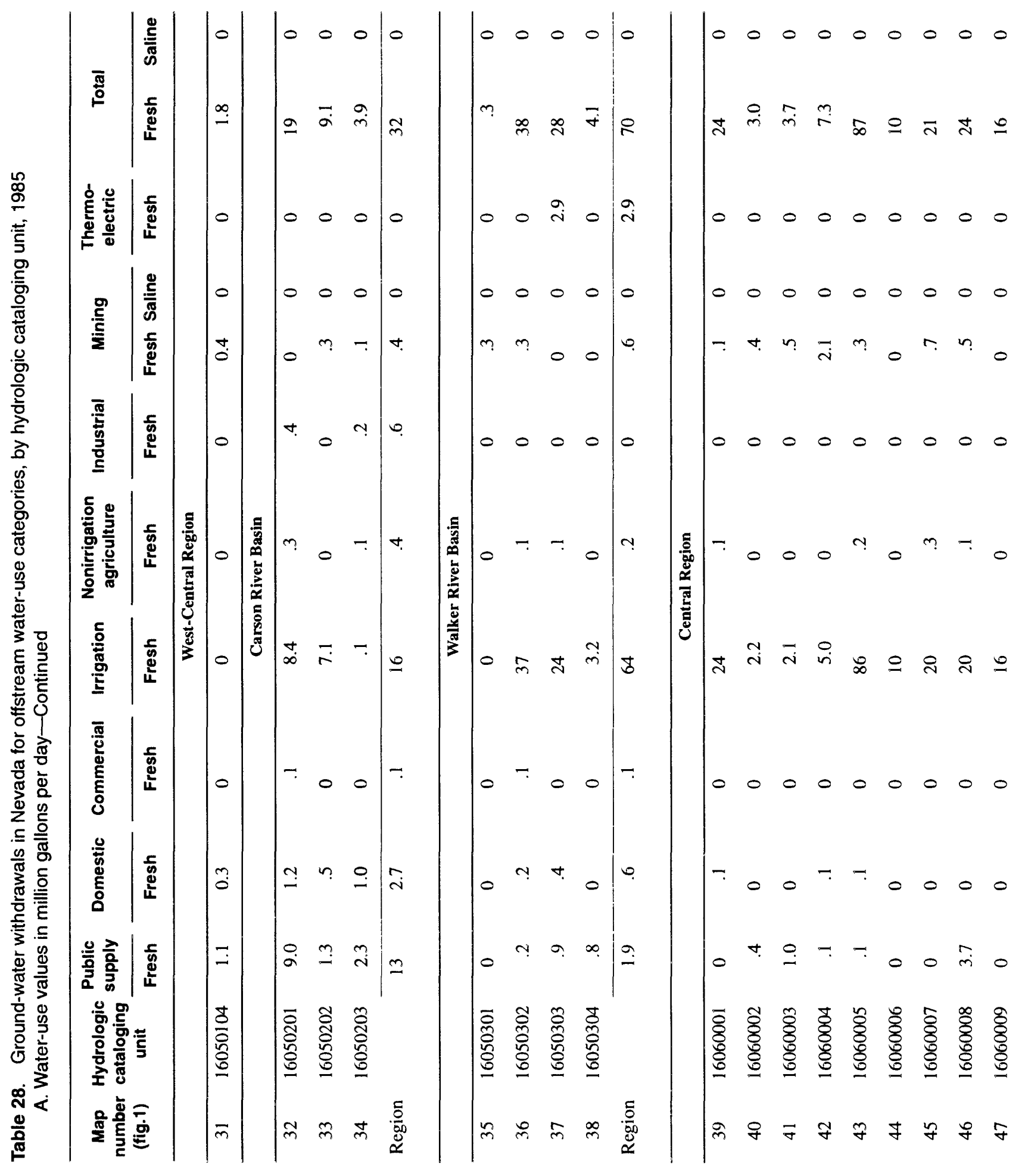




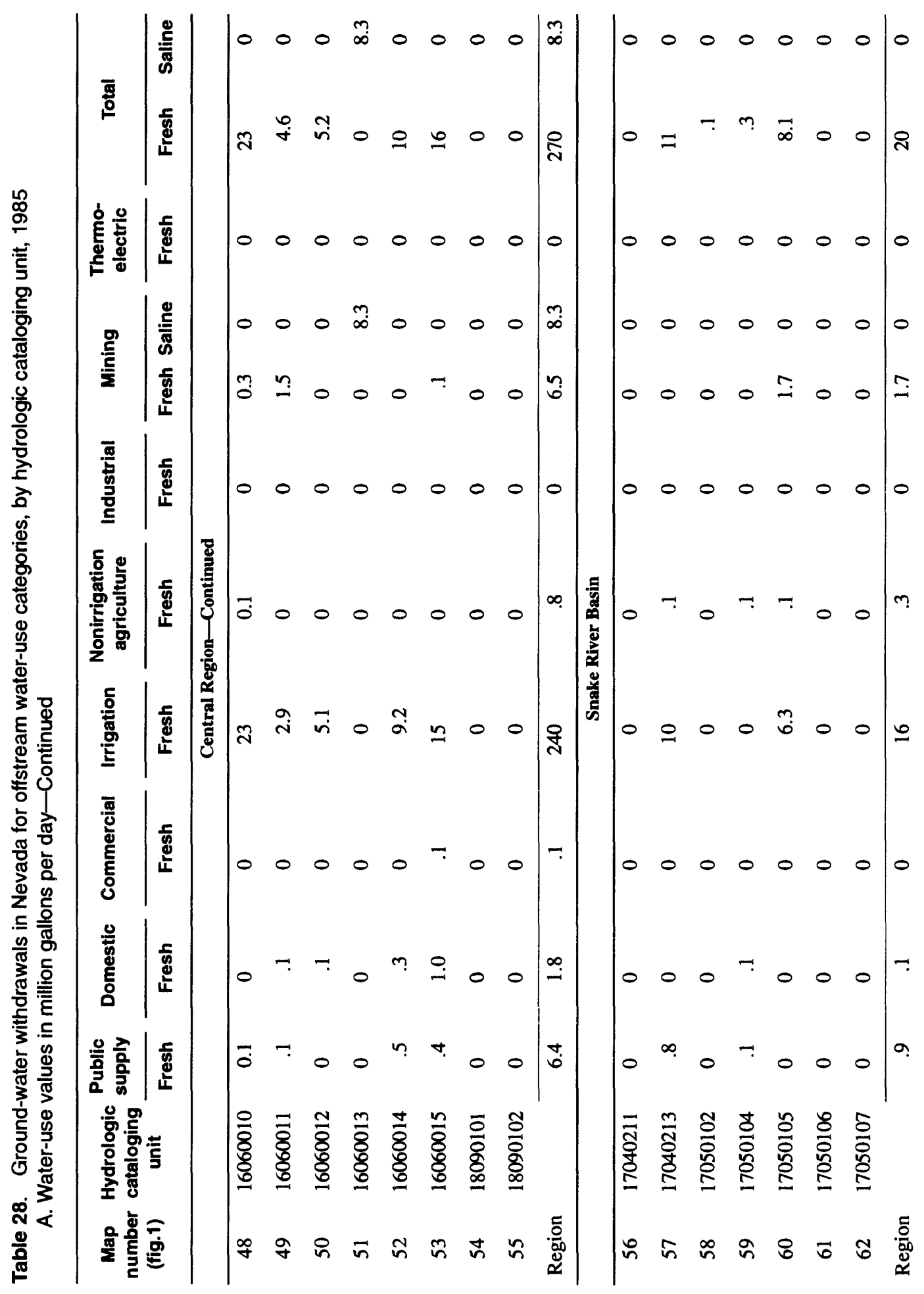




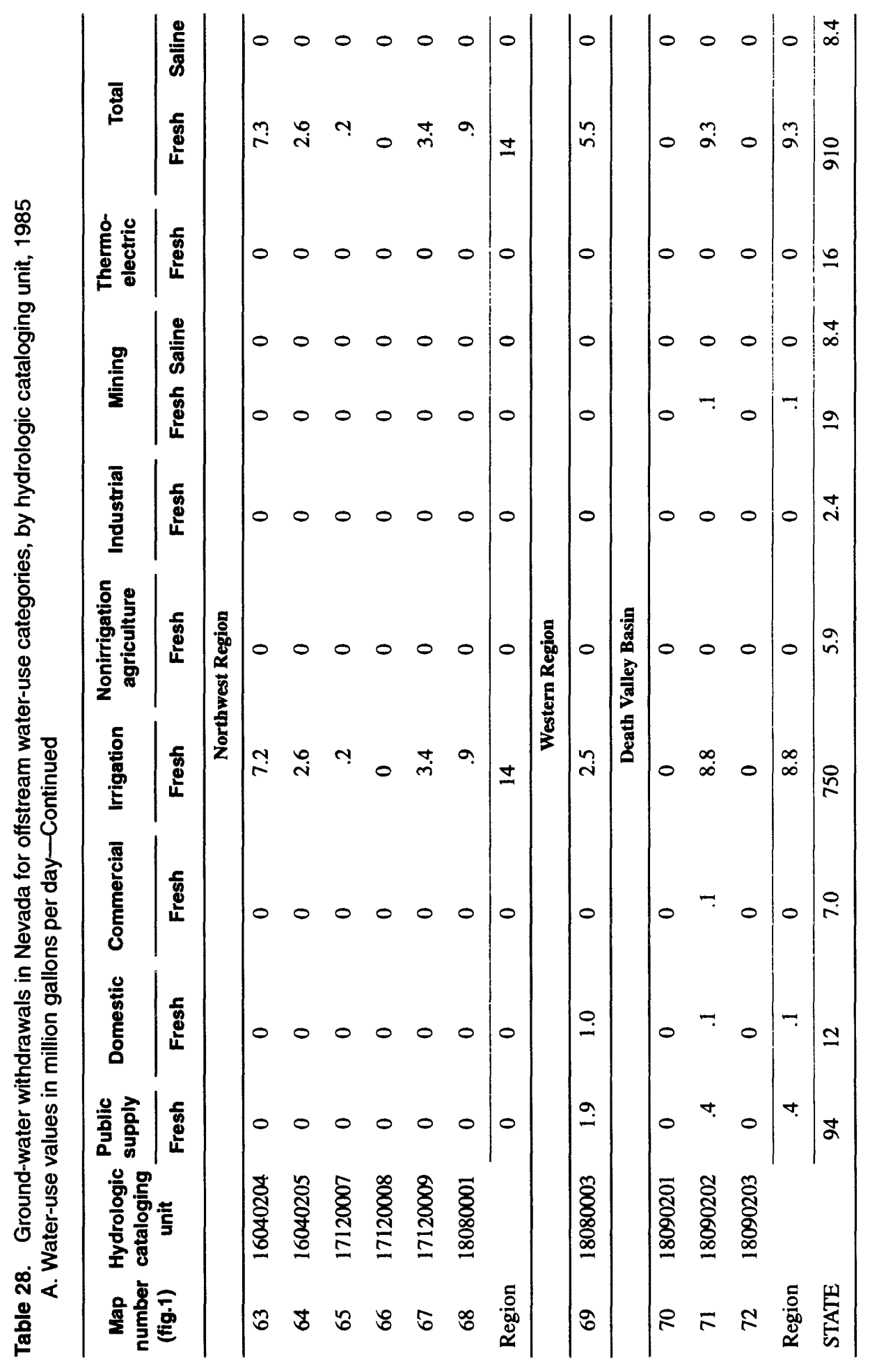




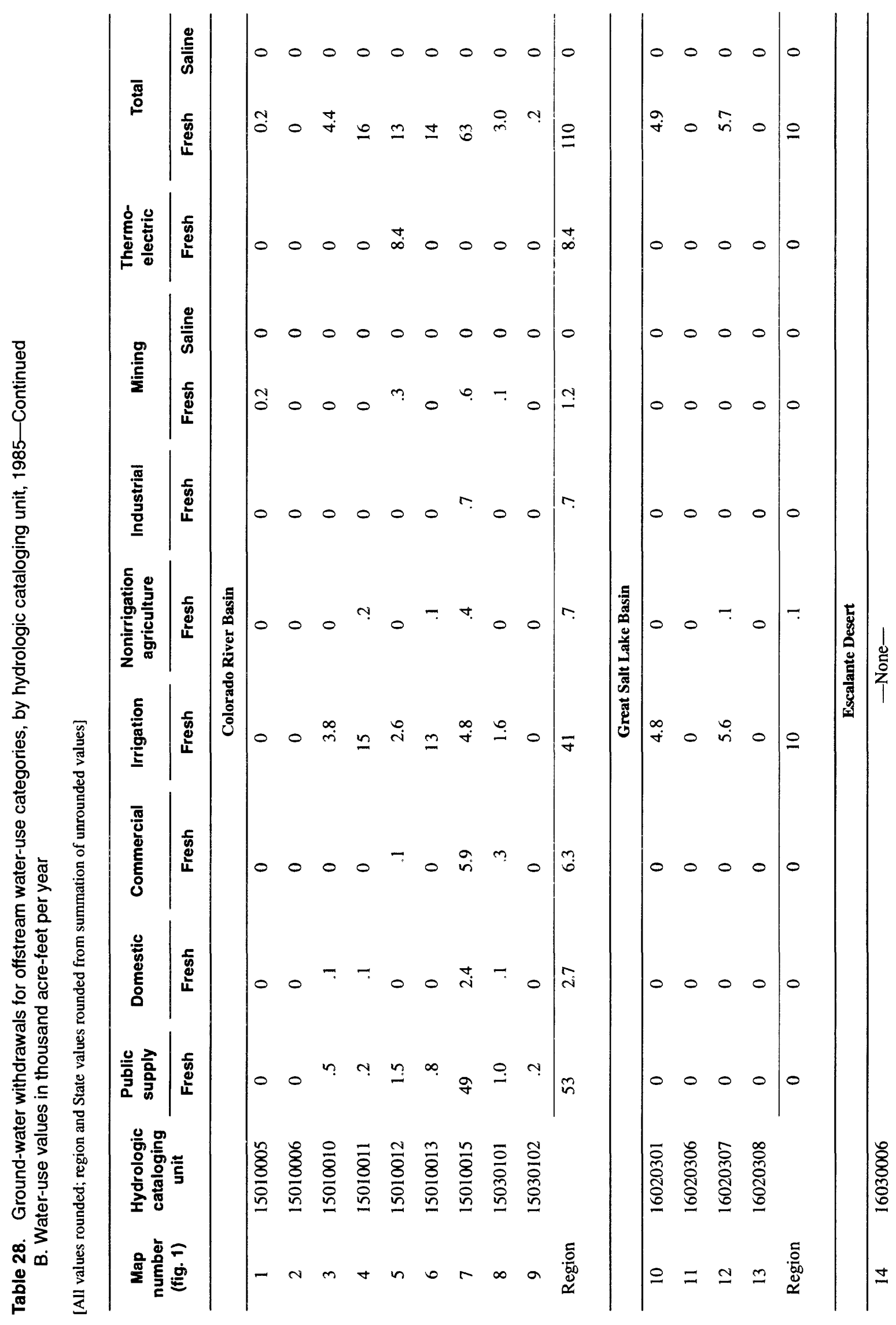




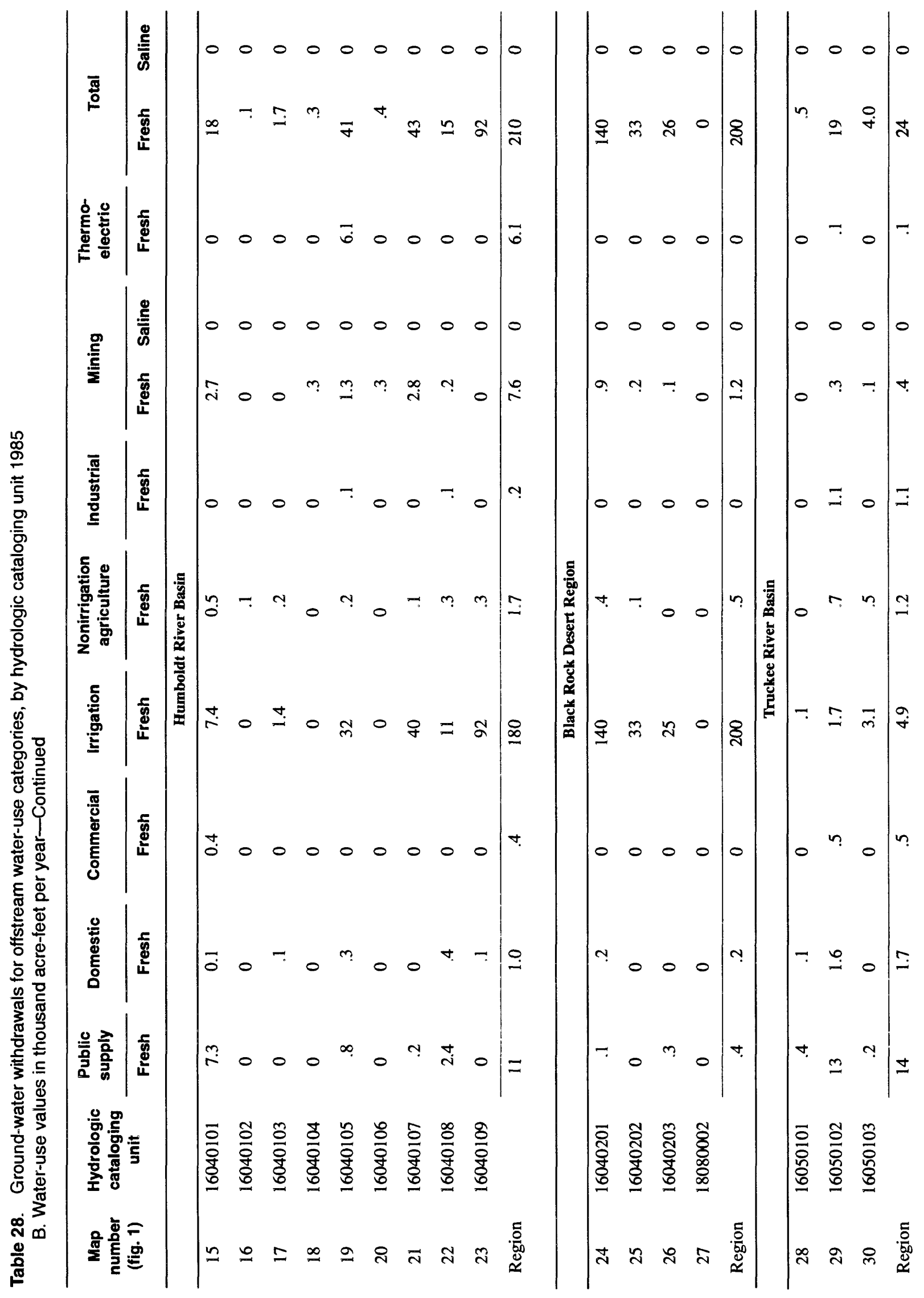




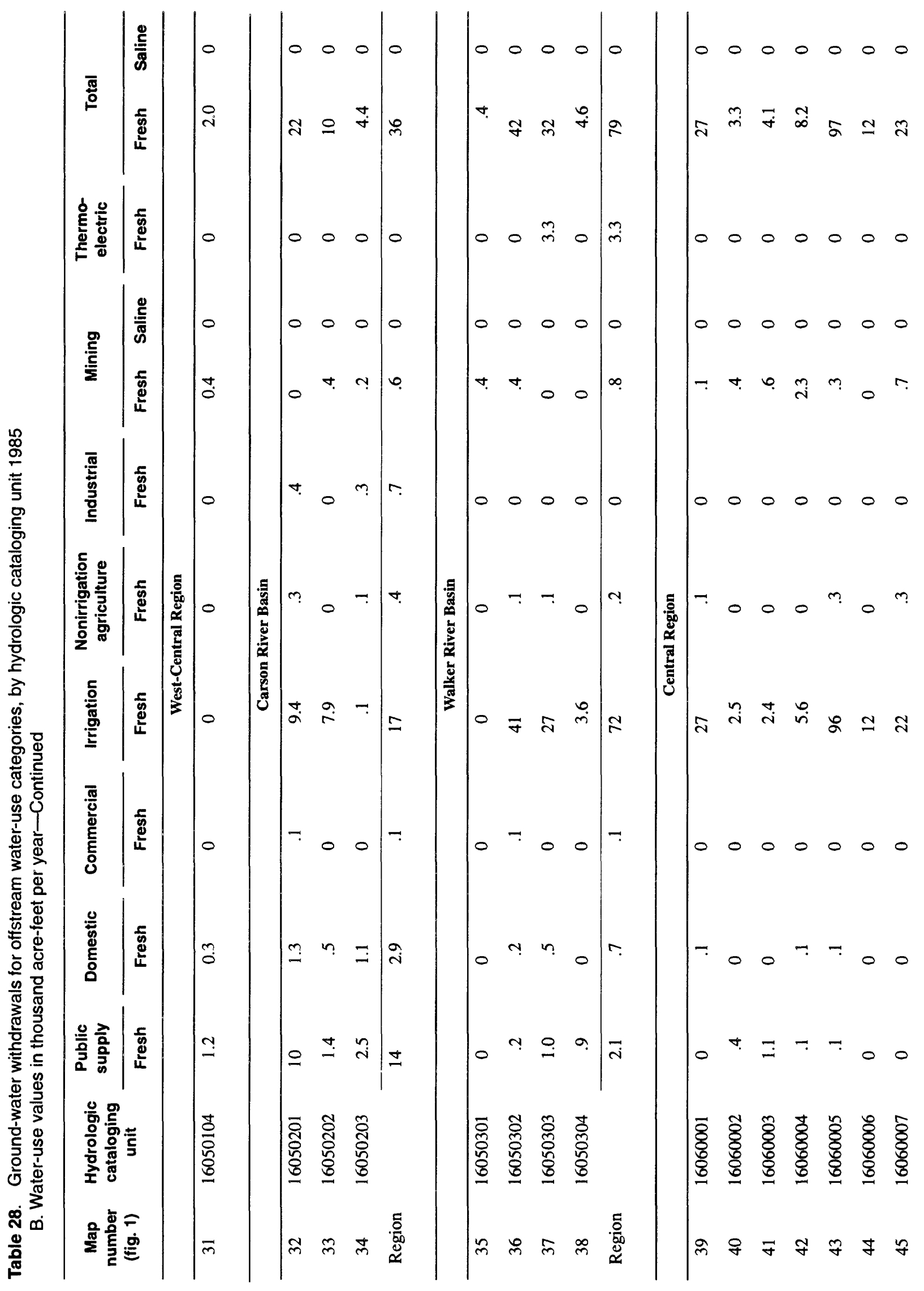




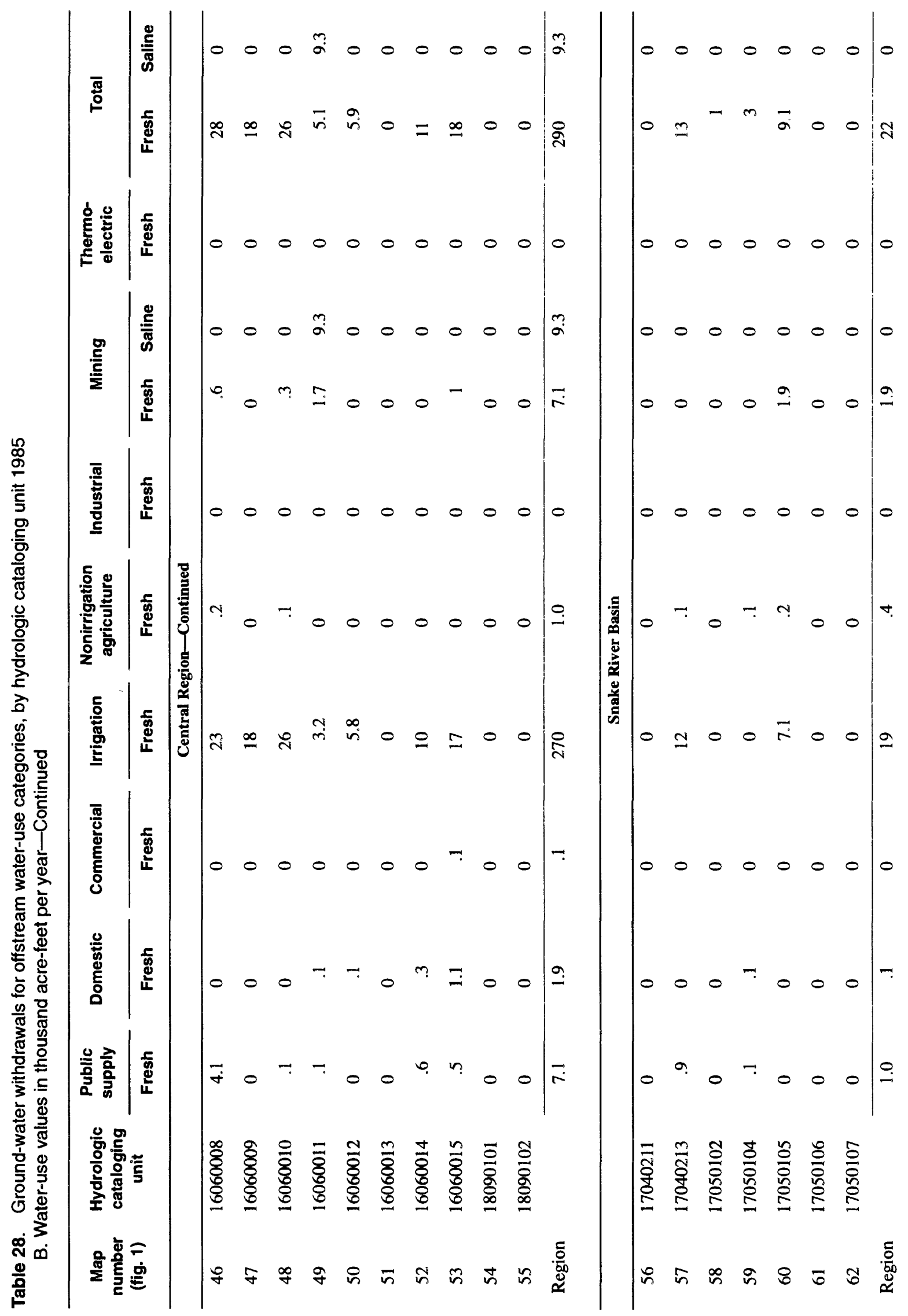




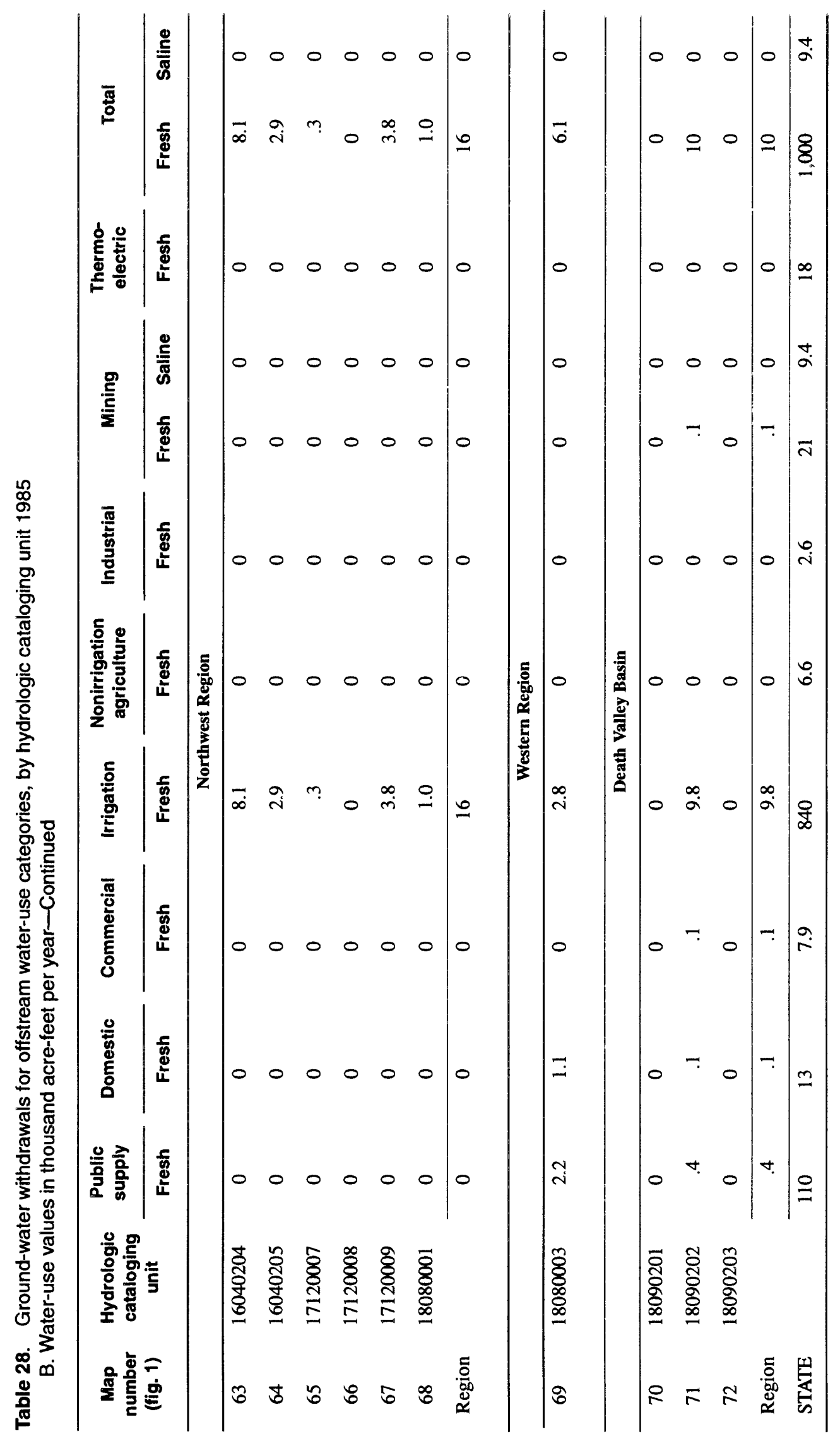


Table 29. Ground-water withdrawals in Nevada for offstream water-use categories, by county, 1985 A. Water-use values in million gallons per day

[All values rounded; State values rounded from summation of unrounded values]

\begin{tabular}{|c|c|c|c|c|c|c|c|c|c|c|c|}
\hline \multirow{2}{*}{ County } & \multirow{2}{*}{$\begin{array}{c}\begin{array}{c}\text { Public } \\
\text { supply }\end{array} \\
\text { Fresh }\end{array}$} & \multirow{2}{*}{$\frac{\text { Domestic }}{\text { Fresh }}$} & \multirow{2}{*}{$\frac{\text { Commercial }}{\text { Fresh }}$} & \multirow{2}{*}{$\frac{\text { Irrigation }}{\text { Fresh }}$} & \multirow{2}{*}{$\begin{array}{c}\begin{array}{c}\text { Nonirrigation } \\
\text { agriculture }\end{array} \\
\text { Fresh }\end{array}$} & \multirow{2}{*}{$\frac{\text { Industrial }}{\text { Fresh }}$} & \multicolumn{2}{|c|}{ Mining } & \multirow{2}{*}{$\begin{array}{c}\begin{array}{c}\text { Thermo- } \\
\text { electric }\end{array} \\
\text { Fresh }\end{array}$} & \multicolumn{2}{|c|}{ Total } \\
\hline & & & & & & & Fresh & Saline & & Fresh & Saline \\
\hline Carson City & 6.0 & 0.2 & 0 & 0 & 0 & 0.2 & 0 & 0 & 0 & 6.5 & 0 \\
\hline Churchill & 2.3 & 1.0 & 0 & 11 & .5 & .2 & 1 & 0 & 0 & 15 & 0 \\
\hline Clark & 47 & 2.7 & 5.7 & 12 & .6 & .6 & 1.1 & 0 & 7.4 & 77 & 0 \\
\hline Douglas & 3.5 & 1.2 & .1 & 9.4 & .2 & .2 & .3 & 0 & 0 & 15 & 0 \\
\hline Elko & 8.7 & .4 & .4 & 52 & 1.3 & 0 & 2.2 & 0 & 0 & 65 & 0 \\
\hline Esmeralda & .1 & .1 & 0 & 25 & .2 & 0 & 1.6 & 8.3 & 0 & 27 & 8.3 \\
\hline Eureka & .1 & .1 & 0 & 100 & .2 & 0 & 2.8 & 0 & 0 & 110 & 0 \\
\hline Humboldt & 1.4 & .7 & 0 & 250 & .4 & .1 & 1.7 & 0 & 5.4 & 260 & 0 \\
\hline Lander & .9 & .1 & 0 & 49 & .2 & 0 & 3.4 & 0 & 0 & 53 & 0 \\
\hline Lincoln & .9 & .1 & 0 & 38 & .2 & 0 & .2 & 0 & 0 & 39 & 0 \\
\hline Lyon & 3.2 & 1.1 & .1 & 67 & .2 & 0 & .6 & 0 & 2.9 & 75 & 0 \\
\hline Mineral & .9 & .1 & 0 & 4.4 & .1 & 0 & .5 & 0 & 0 & 5.9 & 0 \\
\hline Nye & 2.1 & .9 & .1 & 36 & .2 & 0 & 2.7 & 0 & 0 & 42 & 0 \\
\hline Pershing & .9 & .1 & 0 & 19 & .1 & 0 & .2 & 0 & 0 & 20 & 0 \\
\hline Storey & 0 & .1 & 0 & 0 & 0 & 0 & .2 & 0 & .1 & .4 & 0 \\
\hline Washoe & 14 & 2.5 & .5 & 34 & 1.2 & 1.0 & .3 & 0 & 0 & 54 & 0 \\
\hline White Pine & 2.3 & .1 & 0 & 42 & .3 & 0 & .8 & 0 & 0 & 45 & 0 \\
\hline STATE & 94 & 12 & 7.0 & 750 & 5.9 & 2.4 & 19 & 8.4 & 16 & 910 & 8.4 \\
\hline
\end{tabular}


Table 29. Ground-water withdrawals for offstream water-use categories, by county 1985-Continued B. Water-use values in thousand acre-feet per year

[All values rounded, State values rounded from summation of unrounded values]

\begin{tabular}{|c|c|c|c|c|c|c|c|c|c|c|c|}
\hline \multirow{2}{*}{ County } & \multirow{2}{*}{$\begin{array}{l}\begin{array}{c}\text { Public } \\
\text { supply }\end{array} \\
\text { Fresh }\end{array}$} & \multirow{2}{*}{$\begin{array}{c}\text { Domestic } \\
\text { Fresh }\end{array}$} & \multirow{2}{*}{$\frac{\text { Commercial }}{\text { Fresh }}$} & \multirow{2}{*}{$\begin{array}{c}\text { Irrigation } \\
\text { Fresh }\end{array}$} & \multirow{2}{*}{$\begin{array}{c}\begin{array}{c}\text { Nonirrigation } \\
\text { agriculture }\end{array} \\
\text { Fresh }\end{array}$} & \multirow{2}{*}{$\frac{\text { Industrial }}{\text { Fresh }}$} & \multicolumn{2}{|c|}{ Mining } & \multirow{2}{*}{$\begin{array}{l}\text { Thermo- } \\
\text { electric } \\
\text { Fresh }\end{array}$} & \multicolumn{2}{|c|}{ Total } \\
\hline & & & & & & & Fresh & Saline & & Fresh & Saline \\
\hline Carson City & 6.7 & 0.3 & 0 & 0 & 0 & 0.2 & 0 & 0 & 0 & 7.3 & 0 \\
\hline Churchill & 2.5 & 1.2 & 0 & 12 & .5 & .3 & .2 & 0 & 0 & 17 & 0 \\
\hline Clark & 52 & 3.1 & 6.4 & 13 & .7 & .7 & 1.3 & 0 & 8.4 & 86 & 0 \\
\hline Douglas & 4.0 & 1.3 & .1 & 10 & .3 & .2 & .4 & 0 & 0 & 17 & 0 \\
\hline Elko & 9.8 & .4 & .4 & 58 & 1.4 & 0 & 2.5 & 0 & 0 & 73 & 0 \\
\hline Esmeralda & .2 & .1 & 0 & 28 & .2 & 0 & 1.8 & 0 & 0 & 31 & 0 \\
\hline Eureka & .2 & .1 & 0 & 120 & .3 & 0 & 3.2 & 9.3 & 0 & 120 & 9.3 \\
\hline Humboldt & 1.6 & .8 & 0 & 280 & .4 & .1 & 1.9 & 0 & 6.1 & 290 & 0 \\
\hline Lander & 1.0 & .1 & 0 & 55 & .2 & 0 & 3.8 & 0 & 0 & 60 & 0 \\
\hline Lincoln & 1.0 & .1 & 0 & 42 & .2 & 0 & .2 & 0 & 0 & 44 & 0 \\
\hline Lyon & 3.6 & 1.2 & .1 & 75 & .2 & 0 & .7 & 0 & 3.3 & 84 & 0 \\
\hline Mineral & 1.0 & .1 & 0 & 4.9 & .1 & 0 & 6 & 0 & 0 & 6.7 & 0 \\
\hline Nye & 2.4 & 1.0 & .1 & 40 & .3 & 0 & 3.0 & 0 & 0 & 47 & 0 \\
\hline Pershing & 1.0 & .1 & 0 & 21 & .1 & 0 & .2 & 0 & 0 & 23 & 0 \\
\hline Storey & 0 & .1 & 0 & 0 & 0 & 0 & .2 & 0 & .1 & .4 & 0 \\
\hline Washoe & 16 & 2.8 & .5 & 38 & 1.4 & 1.1 & .3 & 0 & 0 & 60 & 0 \\
\hline White Pine & 2.6 & .2 & 0 & 47 & .3 & 0 & .9 & 0 & 0 & 51 & 0 \\
\hline STATE & 110 & 13 & 7.9 & 840 & 6.6 & 2.6 & 21 & 9.4 & 18 & 1,000 & 9.4 \\
\hline
\end{tabular}


Table 30. Hydroelectric-power water use in Nevada, by hydrologic cataloging unit, 1985

[All valued rounded; region and State values rounded from summation of unrounded values. Abbreviations: acre-ft/yr, acrefeet per year; Mgal/d, million gallons per day]

\begin{tabular}{|c|c|c|c|c|}
\hline \multirow{2}{*}{$\begin{array}{c}\text { Map } \\
\text { number } \\
\text { (fig. 1) }\end{array}$} & \multirow{2}{*}{$\begin{array}{l}\text { Hydrologic } \\
\text { cataloging } \\
\text { unit }\end{array}$} & \multicolumn{2}{|c|}{ Water use } & \multirow{2}{*}{$\begin{array}{c}\text { Power } \\
\text { generated } \\
\text { (gigawatt- } \\
\text { hours) }\end{array}$} \\
\hline & & Mgal/d & $\begin{array}{l}\text { Thousand } \\
\text { acre-ft/yr }\end{array}$ & \\
\hline \multicolumn{5}{|c|}{ Colorado River Basin } \\
\hline 8 & 15030101 & 8,300 & 9,300 & 4,300 \\
\hline Region & & 8,300 & 9,300 & 4,300 \\
\hline \multicolumn{5}{|c|}{ Humboldt River Basin } \\
\hline 15 & 16040101 & 7.2 & 8.1 & .4 \\
\hline Region & & 7.2 & 8.1 & .4 \\
\hline \multicolumn{5}{|c|}{ Truckee River Basin } \\
\hline 29 & 16050102 & 420 & 470 & 33 \\
\hline Region & & 420 & 470 & 33 \\
\hline \multicolumn{5}{|c|}{ Carson River Basin } \\
\hline 34 & 16050203 & 210 & 230 & 11 \\
\hline Region & & 210 & 230 & 11 \\
\hline \multicolumn{5}{|c|}{ Central Region } \\
\hline 45 & 16060007 & .7 & .8 & 0 \\
\hline 48 & 16060010 & .9 & 1.0 & 0 \\
\hline Region & & 1.6 & 1.8 & .1 \\
\hline STATE & & 8,900 & 10,000 & 4,400 \\
\hline
\end{tabular}


Table 31. Hydroelectric-power water use in Nevada, by county, 1985

[All values rounded; State values rounded from summation of unrounded values. Abbreviations: acre-ft/yr, acre-feet per year; Mgal/d, million gallons per day]

\begin{tabular}{|c|c|c|c|}
\hline \multirow{2}{*}{ County } & \multicolumn{2}{|c|}{ Water use } & \multirow{2}{*}{$\begin{array}{c}\text { Power } \\
\text { generated } \\
\text { (gigawatt- } \\
\text { hours) }\end{array}$} \\
\hline & Mgal/d & $\begin{array}{l}\text { Thousand } \\
\text { acre-ft/yr }\end{array}$ & \\
\hline Carson City & 0 & 0 & 0 \\
\hline Churchill & 210 & 230 & 11 \\
\hline Clark & 8,300 & 9,300 & 4,300 \\
\hline Douglas & 0 & 0 & 0 \\
\hline Elko & 8.0 & 8.9 & .4 \\
\hline Esmeralda & .9 & 1.0 & 0 \\
\hline Eureka & 0 & 0 & 0 \\
\hline Humboldt & 0 & 0 & 0 \\
\hline Lander & 0 & 0 & 0 \\
\hline Lincoln & 0 & 0 & 0 \\
\hline Lyon & 0 & 0 & 0 \\
\hline Mineral & 0 & 0 & 0 \\
\hline Nye & 0 & 0 & 0 \\
\hline Pershing & 0 & 0 & 0 \\
\hline Storey & 0 & 0 & 0 \\
\hline Washoe & 420 & 470 & 33 \\
\hline White Pine & 0 & 0 & 0 \\
\hline STATE & 8,900 & 10,000 & 4,400 \\
\hline
\end{tabular}


Table 32. Wastewater-treatment water releases in Nevada, by hydrologic cataloging unit, 1985

[All values rounded; region and State values rounded from summation of unrounded values. Abbreviations: acre- $\mathrm{ft} / \mathrm{yr}$, acre-feet per year; Mgal/d, million gallons per day]

\begin{tabular}{|c|c|c|c|c|c|}
\hline \multirow{2}{*}{$\begin{array}{c}\text { Map } \\
\text { number } \\
\text { (fig. 1) }\end{array}$} & \multirow{2}{*}{$\begin{array}{l}\text { Hydrologic } \\
\text { cataloging - } \\
\text { unit }\end{array}$} & \multicolumn{2}{|c|}{$\begin{array}{c}\text { Number of } \\
\text { facilities }\end{array}$} & \multicolumn{2}{|c|}{$\begin{array}{l}\text { Total public } \\
\text { releases }\end{array}$} \\
\hline & & Public & Other & Mgal/d & $\begin{array}{l}\text { Thousand } \\
\text { acre-ft/yr }\end{array}$ \\
\hline \multicolumn{6}{|c|}{ Colorado River Basin } \\
\hline 1 & 15010005 & 4 & 2 & 0.1 & 0.1 \\
\hline 2 & 15010006 & 0 & 0 & 0 & 0 \\
\hline 3 & 15010010 & 1 & 0 & .3 & .3 \\
\hline 4 & 15010011 & 2 & 0 & .1 & .1 \\
\hline 5 & 15010012 & 3 & 1 & .1 & .2 \\
\hline 6 & 15010013 & 3 & 1 & .4 & .4 \\
\hline 7 & 15010015 & 4 & 7 & 80 & 90 \\
\hline 8 & 15030101 & 2 & 0 & .7 & .8 \\
\hline 9 & 15030102 & 1 & 2 & .1 & .1 \\
\hline Region & & 20 & 13 & 82 & 92 \\
\hline \multicolumn{6}{|c|}{ Great Salt Lake Basin } \\
\hline 10 & 16020301 & 0 & 1 & 0 & 0 \\
\hline 11 & 16020306 & 1 & 0 & .3 & .3 \\
\hline 12 & 16020307 & 1 & 0 & 0 & 0 \\
\hline 13 & 16020308 & 0 & 0 & 0 & 0 \\
\hline Region & & 2 & 1 & .3 & .3 \\
\hline
\end{tabular}

Escalante Desert

\begin{tabular}{rrrrrl}
\hline \multicolumn{5}{c}{ Humboldt River Basin } \\
\hline 15 & 16040101 & 3 & 3 & 2.6 & 2.9 \\
16 & 16040102 & 0 & 0 & 0 & 0 \\
17 & 16040103 & 0 & 0 & 0 & 0 \\
18 & 16040104 & 0 & 1 & 0 & 0 \\
19 & 16040105 & 1 & 4 & .4 & .4 \\
20 & 16040106 & 0 & 0 & 0 & 0 \\
21 & 16040107 & 1 & 0 & 0 & 0 \\
22 & 16040108 & 3 & 4 & 1.8 & 2.0 \\
23 & 16040109 & 1 & 0 & 0 & 0 \\
\cline { 3 - 6 } Region & & 9 & 12 & 4.8 & 5.3
\end{tabular}


Table 32. Wastewater-treatment water releases in Nevada, by hydrologic cataloging unit, 1985Continued

\begin{tabular}{|c|c|c|c|c|c|}
\hline \multirow{2}{*}{$\begin{array}{c}\text { Map } \\
\text { number } \\
\text { (fig. 1) }\end{array}$} & \multirow{2}{*}{$\begin{array}{c}\text { Hydrologic } \\
\text { cataloging } \\
\text { unit }\end{array}$} & \multicolumn{2}{|c|}{$\begin{array}{l}\text { Number of } \\
\text { facilities }\end{array}$} & \multicolumn{2}{|c|}{$\begin{array}{l}\text { Total public } \\
\text { releases }\end{array}$} \\
\hline & & Public & Other & Mgal/d & $\begin{array}{l}\text { Thousand } \\
\text { acre-ft/yr }\end{array}$ \\
\hline \multicolumn{6}{|c|}{ Black Rock Desert Region } \\
\hline 24 & 16040201 & 1 & 0 & 0 & 0 \\
\hline 25 & 16040202 & 1 & 0 & 0 & 0 \\
\hline 26 & 16040203 & 1 & 0 & .1 & .1 \\
\hline 27 & 18080002 & 0 & 0 & 0 & 0 \\
\hline Region & & 3 & 0 & .1 & .1 \\
\hline \multicolumn{6}{|c|}{ Truckee River Basin } \\
\hline 28 & 16050101 & 3 & 1 & .1 & .1 \\
\hline 29 & 16050102 & 8 & 20 & 26 & 29 \\
\hline 30 & 16050103 & 0 & 0 & 0 & 0 \\
\hline Region & & 11 & 21 & 26 & 29 \\
\hline
\end{tabular}

\begin{tabular}{cccccc}
\hline \multicolumn{6}{c}{ West-Central Region } \\
\hline 31 & 16050104 & 2 & 2 & .3 & .3 \\
\hline \multicolumn{5}{c}{ Carson River Basin } \\
32 & 16050201 & 4 & 5 & 10 & 12 \\
34 & 16050202 & 2 & 2 & .3 & .4 \\
Region & 16050203 & 1 & 2 & .4 & .4 \\
\hline & & 7 & 9 & 10 & 13 \\
\hline
\end{tabular}

\begin{tabular}{cccccc}
\hline \multicolumn{5}{c}{ Walker River Basin } \\
\hline 35 & 16050301 & 0 & 0 & 0 & 0 \\
36 & 16050302 & 1 & 1 & .1 & .1 \\
37 & 16050303 & 5 & 0 & .5 & .5 \\
38 & 16050304 & 1 & 2 & .3 & .4 \\
\cline { 3 - 6 } Region & & 7 & 3 & .9 & 1.0 \\
\hline & & Central Region & & \\
\hline 39 & 16060001 & 0 & 1 & 0 & 0 \\
40 & 16060002 & 1 & 0 & .1 & .1 \\
41 & 16060003 & 2 & 1 & .5 & .5 \\
42 & 16060004 & 1 & 1 & 0 & 0 \\
43 & 16060005 & 1 & 0 & 0 & 0 \\
44 & 16060006 & 0 & 0 & 0 & 0 \\
45 & 16060007 & 0 & 2 & 0 & 0 \\
46 & 16060008 & 3 & 3 & 1.3 & 1.4
\end{tabular}


Table 32. Wastewater-treatment water releases in Nevada, by hydrologic cataloging unit, 1985Continued

\begin{tabular}{|c|c|c|c|c|c|}
\hline \multirow{2}{*}{$\begin{array}{c}\text { Map } \\
\text { number } \\
\text { (fig. 1) }\end{array}$} & \multirow{2}{*}{$\begin{array}{c}\text { Hydrologic } \\
\text { cataloging } \\
\text { unit }\end{array}$} & \multicolumn{2}{|c|}{$\begin{array}{l}\text { Number of } \\
\text { facilities }\end{array}$} & \multicolumn{2}{|c|}{$\begin{array}{l}\text { Total public } \\
\text { releases }\end{array}$} \\
\hline & & Public & Other & $\mathrm{Mgal} / \mathrm{d}$ & $\begin{array}{l}\text { Thousand } \\
\text { acre-ft/yr }\end{array}$ \\
\hline \multicolumn{6}{|c|}{ Central Region-Continued } \\
\hline 47 & 16060009 & 0 & 0 & 0 & 0 \\
\hline 48 & 16060010 & 0 & 3 & 0 & 0 \\
\hline 49 & 16060011 & 1 & 3 & 0 & 0 \\
\hline 50 & 16060012 & 0 & 0 & 0 & 0 \\
\hline 51 & 16060013 & 0 & 0 & 0 & 0 \\
\hline 52 & 16060014 & 3 & 1 & .3 & .3 \\
\hline 53 & 16060015 & 3 & 2 & 1.1 & 1.2 \\
\hline 54 & 18090101 & 0 & 0 & 0 & 0 \\
\hline 55 & 18090102 & 0 & 0 & 0 & 0 \\
\hline Region & & 15 & 17 & 5.3 & 3.5 \\
\hline \multicolumn{6}{|c|}{ Snake River Basin } \\
\hline 56 & 17040211 & 0 & 0 & 0 & 0 \\
\hline 57 & 17040213 & 1 & 0 & .1 & .1 \\
\hline 58 & 17050102 & 0 & 0 & 0 & 0 \\
\hline 59 & 17050104 & 2 & 1 & .1 & .1 \\
\hline 60 & 17050105 & 0 & 2 & 0 & 0 \\
\hline 61 & 17050106 & 0 & 0 & 0 & 0 \\
\hline 62 & 17050107 & 0 & 0 & 0 & 0 \\
\hline Region & & 3 & 3 & .2 & .2 \\
\hline \multicolumn{6}{|c|}{ Northwest Region } \\
\hline \multicolumn{6}{|c|}{-None- } \\
\hline \multicolumn{6}{|c|}{ Western Region } \\
\hline 69 & 18080003 & 1 & 0 & .1 & .1 \\
\hline \multicolumn{6}{|c|}{ Death Valley Basin } \\
\hline 70 & 18090201 & 0 & 0 & 0 & 0 \\
\hline 71 & 18090202 & 3 & 1 & .4 & .4 \\
\hline 72 & 18090203 & 0 & 0 & 0 & 0 \\
\hline Region & & 3 & 1 & .4 & .4 \\
\hline STATE & & 83 & 82 & 130 & 140 \\
\hline
\end{tabular}


Table 33. Wastewater-treatment water releases in Nevada, by county, 1985

[All values rounded; State values rounded from summation of unrounded values. Abbreviations: acre-ft/yr, acre-feet per year; $\mathrm{Mgal} / \mathrm{d}$, million gallons per day]

\begin{tabular}{|c|c|c|c|c|}
\hline \multirow{2}{*}{ County } & \multicolumn{2}{|c|}{$\begin{array}{l}\text { Number of } \\
\text { facilities }\end{array}$} & \multicolumn{2}{|c|}{$\begin{array}{l}\text { Total public } \\
\text { releases }\end{array}$} \\
\hline & Public & Other & Mgal/d & $\begin{array}{l}\text { Thousand } \\
\text { acre-ft/yr }\end{array}$ \\
\hline Carson City & 1 & 0 & 4.9 & 5.5 \\
\hline Churchill & 1 & 3 & .4 & .4 \\
\hline Clark & 22 & 13 & 83 & 93 \\
\hline Douglas & 4 & 6 & 4.6 & 5.2 \\
\hline Elko & 8 & 7 & 3.0 & 3.4 \\
\hline Esmeralda & 1 & 3 & 0 & 0 \\
\hline Eureka & 1 & 2 & 0 & 0 \\
\hline Humboldt & 4 & 5 & 1.6 & 1.8 \\
\hline Lander & 2 & 2 & .4 & .4 \\
\hline Lincoln & 3 & 2 & .4 & .4 \\
\hline Lyon & 7 & 4 & 1.0 & 1.1 \\
\hline Mineral & 2 & 4 & .4 & .4 \\
\hline Nye & 7 & 4 & 1.0 & 1.1 \\
\hline Pershing & 2 & 1 & .3 & .3 \\
\hline Storey & 1 & 2 & .1 & .1 \\
\hline Washoe & 14 & 20 & 27 & 30 \\
\hline White Pine & 3 & 4 & 1.3 & 1.4 \\
\hline STATE & 83 & 82 & 130 & 140 \\
\hline
\end{tabular}


Table 34. Summary of estimated water use in Nevada, 1950-85

[Data for 1950-85 adapted from MacKichan (1951, 1957), MacKichan and Kammerer (1961), Murray (1968), Murray and Reeves $(1972,1977)$, and Solley and others $(1983,1988)$. Water-use values rounded to two significant figures, in million gallons per day. Abbreviation: NR, not reported]

\begin{tabular}{|c|c|c|c|c|c|c|c|c|}
\hline & \multicolumn{8}{|c|}{ Year } \\
\hline & 1950 & 1955 & 1960 & 1965 & 1970 & 1975 & 1980 & 1985 \\
\hline Population, in thousands & 160 & NR & 285 & 393 & 489 & 610 & 801 & 968 \\
\hline \multicolumn{9}{|l|}{ Offstream use: } \\
\hline Total withdrawals & 1,700 & 2,000 & 2,300 & 2,200 & 3,300 & 3,500 & 3,600 & 3,700 \\
\hline Public supply & 45 & 65 & 79 & 110 & 130 & 180 & 230 & 290 \\
\hline Rural domestic and livestock & 8 & 11 & 9.7 & 17 & 13 & 20 & 23 & 25 \\
\hline Irrigation & 1,700 & 1,900 & 2,000 & 2,000 & 3,000 & 3,100 & 3,100 & 3,300 \\
\hline Thermoelectric power & $16^{\mathrm{a}}$ & $53^{\mathrm{a}}$ & 0 & 28 & 57 & 95 & 94 & 24 \\
\hline Industrial & $16^{\mathrm{a}}$ & $53^{\mathrm{a}}$ & 44 & 52 & 70 & 120 & 140 & 40 \\
\hline \multicolumn{9}{|l|}{ Source of water } \\
\hline Fresh & 180 & 260 & 360 & 560 & 520 & 670 & 710 & 910 \\
\hline Saline & NR & 0 & 3.0 & 2.7 & 6.2 & 13 & 9 & 8.4 \\
\hline \multicolumn{9}{|l|}{ Surface water } \\
\hline Fresh & 1,400 & 1,800 & 1,500 & 1,600 & 2,700 & 2,800 & 2,900 & 2,800 \\
\hline Saline & NR & 0 & 0 & 0 & 0 & 0 & 0 & 0 \\
\hline Reclaimed wastewater & NR & 6.8 & .2 & 1.2 & 4.2 & 11 & 14 & 11 \\
\hline Consumptive use & NR & NR & 1,000 & 1,300 & 1,500 & 1,600 & 1,700 & 1,900 \\
\hline \multicolumn{9}{|l|}{ Instream use: } \\
\hline Hydroelectric power & 6,600 & 3,300 & 5,500 & 4,400 & 4,200 & 4,600 & 1,200 & 8,900 \\
\hline
\end{tabular}

${ }^{\text {a }}$ For 1950 and 1955, the thermoelectric-power and industrial water-use categories were combined; the value presented is the total for these two categories. 